Prepared in cooperation with the Missouri Department of Transportation and Clarkson Construction

\title{
Bathymetric and Velocimetric Surveys at Highway Bridges Crossing the Missouri River near Kansas City, Missouri, August 2019, August 2020, and October 2020
}

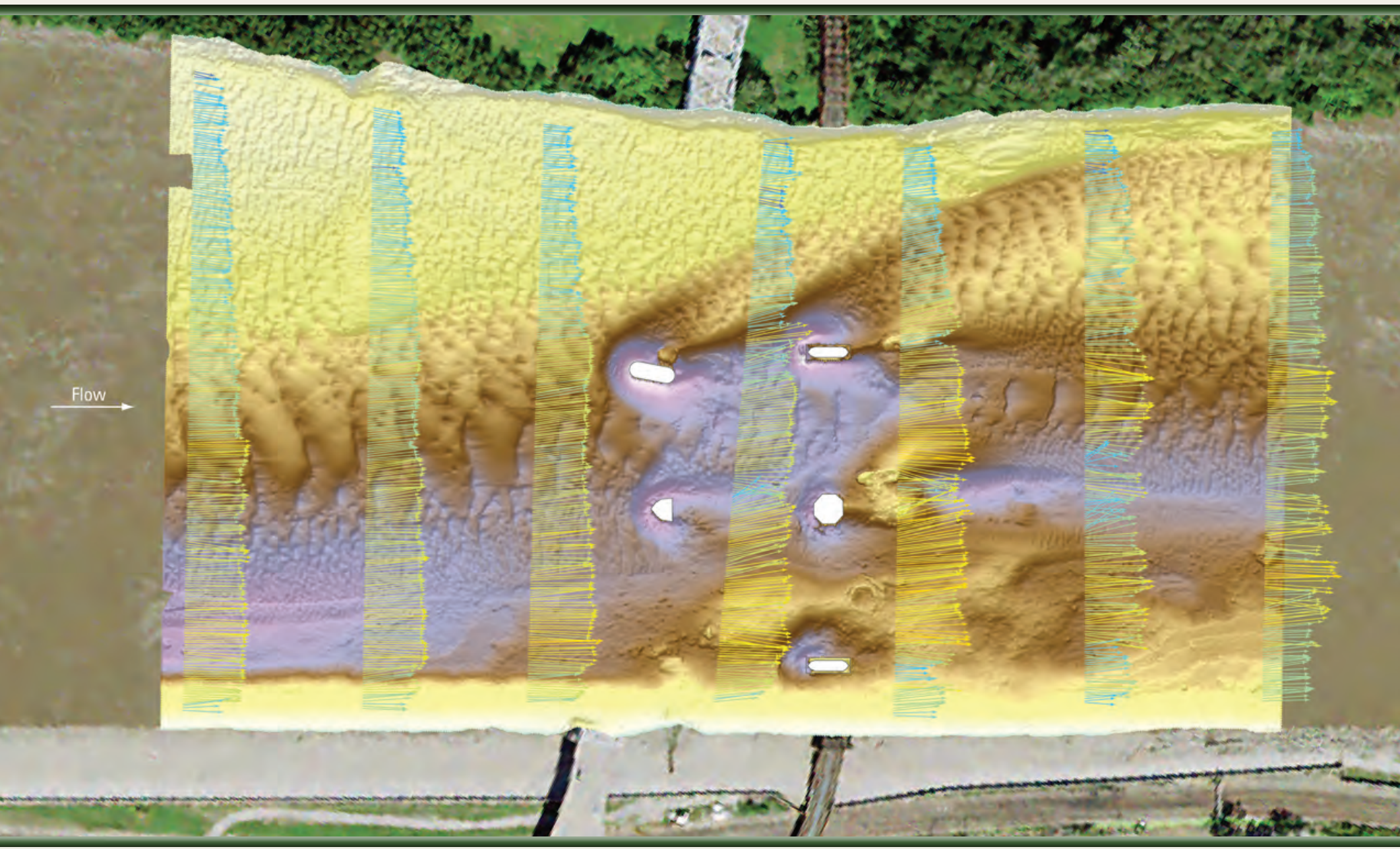

Scientific Investigations Report 2021-5098 
Cover: Bathymetry and vertically averaged velocities of the Missouri River channel near structure A4649 on U.S. Highway 169 in Kansas City, Missouri, on August 13, 2019. All photographs by Richard Huizinga, U.S. Geological Survey. 


\section{Bathymetric and Velocimetric Surveys at Highway Bridges Crossing the Missouri River near Kansas City, Missouri, August 2019, August 2020, and October 2020}

By Richard J. Huizinga

Prepared in cooperation with the Missouri Department of Transportation and Clarkson Construction

Scientific Investigations Report 2021-5098 


\section{U.S. Geological Survey, Reston, Virginia: 2022}

For more information on the USGS - the Federal source for science about the Earth, its natural and living resources, natural hazards, and the environment—visit https://www.usgs.gov or call 1-888-ASK-USGS.

For an overview of USGS information products, including maps, imagery, and publications, visit https://store.usgs.gov/.

Any use of trade, firm, or product names is for descriptive purposes only and does not imply endorsement by the U.S. Government.

Although this information product, for the most part, is in the public domain, it also may contain copyrighted materials as noted in the text. Permission to reproduce copyrighted items must be secured from the copyright owner.

Suggested citation:

Huizinga, R.J., 2022, Bathymetric and velocimetric surveys at highway bridges crossing the Missouri River near Kansas City, Missouri, August 2019, August 2020, and October 2020: U.S. Geological Survey Scientific Investigations Report 2021-5098, 112 p., https://doi.org/10.3133/sir20215098.

Associated data for this publication:

Huizinga, R.J., 2021, Bathymetry and velocity data from surveys at highway bridges crossing the Missouri River in Kansas City, Missouri, in August 2019, August 2020, and October 2020: U.S. Geological Survey data release, https:// doi.org/10.5066/P96TX8AE.

U.S. Geological Survey, 2020, USGS water data for the Nation: U.S. Geological Survey National Water Information System database, https://doi.org/10.5066/F7P55KJN.

ISSN 2328-0328 (online) 


\section{Acknowledgments}

The author would like to acknowledge Dennis Heckmann (retired), Bryan Hartnagel, and Jennifer Harper at the Missouri Department of Transportation for their role in funding and supporting the work of the project detailed in this report. The author also would like to acknowledge Jonathan Baker and Damon Johnson at Clarkson Construction for their role in requesting and funding the special surveys at structure A4649 on U.S. Highway 169 and structure A0767 on Interstate 435 to document the installation of the scour countermeasures there.

The author also wishes to gratefully acknowledge the assistance of several current and former colleagues at the U.S. Geological Survey Central Midwest Water Science Center for their assistance in collecting and processing the data for this project. Jarrett T. Ellis (former employee) was instrumental in collecting and initial processing of the data from the August 2019 surveys. Benjamin C. Rivers was instrumental in collecting the data from the two special surveys near the main channel piers of the Broadway and Randolph bridges in August and October 2020. 



\section{Contents}

Acknowledgments ……...................................................................................................................

Abstract

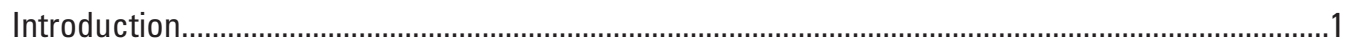

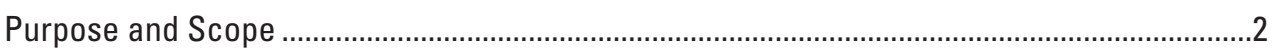

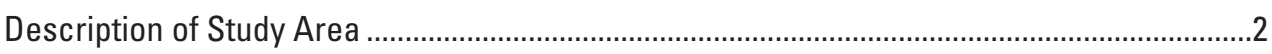

Description of Streamflow Conditions .............................................................................

Description of Equipment and Basic Processing ..................................................................

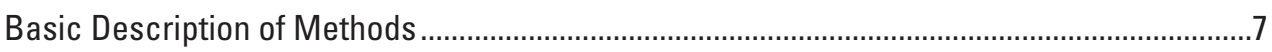

Surveying Methods ...........................................................................................................

Survey Quality-Assurance/Quality-Control Measures .......................................................7

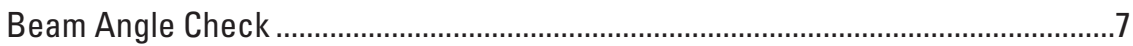

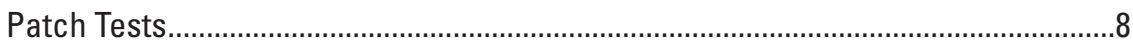

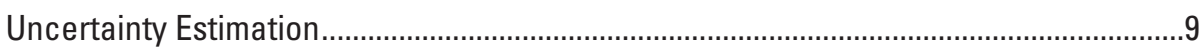

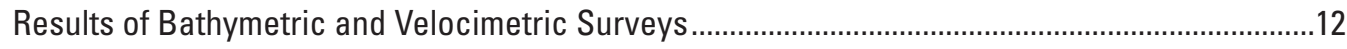

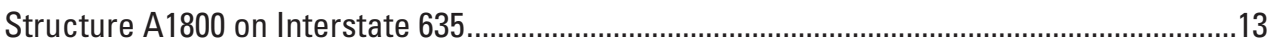

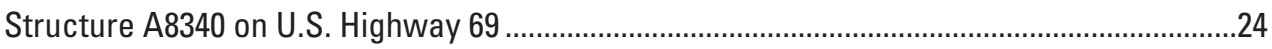

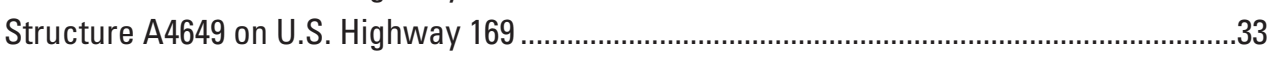

Structure A4060 on State Highway 9 ............................................................................. 46

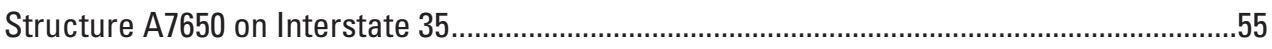

Structure A5817 on State Highway 269.......................................................................

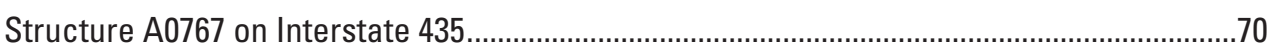

Structures A4757 and L0568 on State Highway 291 .........................................................83

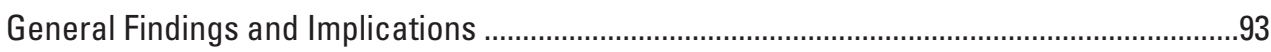

Effects of Moderate Flooding Compared to Previous Surveys .........................................93

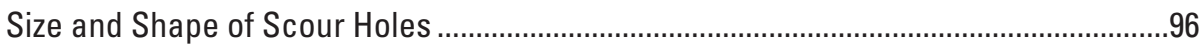

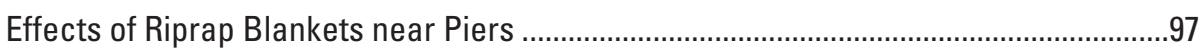

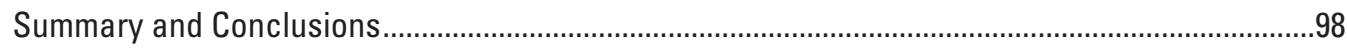

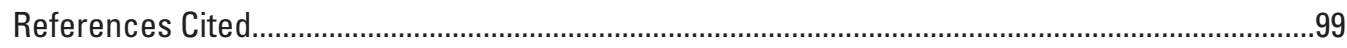

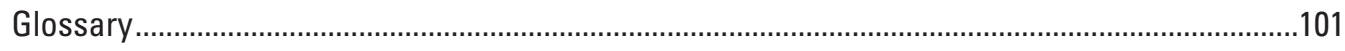

Appendix 1. Shaded Triangulated Irregular Network Images of the Channel and Side of

Pier for Each Surveyed Pier ....................................................................................................102

\section{Figures}

1. Map showing the location of highway bridges crossing the Missouri River in and into Missouri in the Kansas City, Missouri, area ........................................................

2. Graphs showing unit values of streamflow from the streamflow-gaging station on the Missouri River at Kansas City, Missouri .............................................................5

3. Images showing the Norbit iWBMSh multibeam echosounder ........................................6

4. Diagrams showing generalized effects on data from a multibeam echosounder.............9

5. Map showing uncertainty of gridded bathymetric data from the Missouri River channel near structures A4757 and L0568 on State Highway 291 near Kansas City, Missouri. 
6. Map showing the bathymetric survey of the Missouri River channel near structure A1800 on Interstate 635 in Kansas City, Missouri, on August 13, 2019 14

7. Graph showing the frequency distribution of bed elevations for bathymetric survey-grid cells in 1-foot elevation bins on the Missouri River near structure A1800 on Interstate 635 in Kansas City, Missouri, on August 13, 2019, compared to previous surveys in 2010, 2011, and 2015

8. Diagram showing key features, substructural and superstructural details, and surveyed channel bed of structure A1800 on Interstate 635 crossing the Missouri River in Kansas City, Missouri.

9. Map showing the difference between surfaces created from bathymetric surveys of the Missouri River channel near structure A1800 on Interstate 635 in Kansas City, Missouri, on August 13, 2019, and June 2, 2015.

10. Map showing the difference between surfaces created from bathymetric surveys of the Missouri River channel near structure A1800 on Interstate 635 in Kansas City, Missouri, on August 13, 2019, and July 16, 2011

11. Map showing the difference between surfaces created from bathymetric surveys of the Missouri River channel near structure A1800 on Interstate 635 in Kansas City, Missouri, on August 13, 2019, and March 15, 2010.

12. Map showing bathymetry and vertically averaged velocities of the Missouri River channel near structure A1800 on Interstate 635 in Kansas City, Missouri, on August 13, 2019

13. Map showing the bathymetric survey of the Missouri River channel near structure A8340 on U.S. Highway 69 in Kansas City, Missouri, on August 13, 2019........25

14. Graph showing the frequency distribution of bed elevations for bathymetric survey-grid cells in 1-foot elevation bins on the Missouri River near structure A8340 on U.S. Highway 69 in Kansas City, Missouri, on August 13, 2019, compared to previous surveys in 2010, 2011, and 2017

15. Diagram showing key features, substructural and superstructural details, and surveyed channel bed of structure A8340 on U.S. Highway 69 crossing the Missouri River in Kansas City, Missouri.

16. Map showing the difference between surfaces created from bathymetric surveys of the Missouri River channel near structure A8340 on U.S. Highway 69 in Kansas City, Missouri, on August 13, 2019, and May 22, 2017.

17. Map showing the difference between surfaces created from bathymetric surveys of the Missouri River channel near structure A8340 on U.S. Highway 69 in Kansas City, Missouri, on August 13, 2019, and July 16, 2011

18. Map showing the difference between surfaces created from bathymetric surveys of the Missouri River channel near structure A8340 on U.S. Highway 69 in Kansas City, Missouri, on August 13, 2019, and March 15, 2010.

19. Map showing the bathymetry and vertically averaged velocities of the Missouri River channel near structure A8340 on U.S. Highway 69 in Kansas City, Missouri, on August 13, 2019.

20. Map showing the bathymetric survey of the Missouri River channel near structure A4649 on U.S. Highway 169 in Kansas City, Missouri, on August 13, 2019.......34

21. Graph showing the frequency distribution of bed elevations for bathymetric survey-grid cells in 1-foot elevation bins on the Missouri River near structure A4649 on U.S. Highway 169 in Kansas City, Missouri, on August 13, 2019, compared to previous surveys in 2010, 2011, and 2015 . 
22. Diagram showing key features, substructural and superstructural details, and surveyed channel bed of structure A4649 on U.S. Highway 169 crossing the Missouri River in Kansas City, Missouri...

23. Map showing the difference between surfaces created from bathymetric surveys of the Missouri River channel near structure A4649 on U.S. Highway 169 in Kansas City, Missouri, on August 13, 2019, and June 22, 2015.

24. Map showing the difference between surfaces created from bathymetric surveys of the Missouri River channel near structure A4649 on U.S. Highway 169 in Kansas City, Missouri, on August 13, 2019, and July 17, 2011.

25. Map showing the difference between surfaces created from bathymetric surveys of the Missouri River channel near structure A4649 on U.S. Highway 169 in Kansas City, Missouri, on August 13, 2019, and March 16, 2010.

26. Map showing bathymetry and vertically averaged velocities of the Missouri River channel near structure A4649 on U.S. Highway 169 in Kansas City, Missouri, on August 13, 2019

27. Map showing the bathymetric survey of the Missouri River channel near the main channel pier of structure A4649 on U.S. Highway 169 in Kansas City, Missouri, on August 17, 2020, before installation of scour countermeasures.

28. Map showing the difference between surfaces created from bathymetric surveys of the Missouri River channel near the main channel pier of structure A4649 on U.S. Highway 169 in Kansas City, Missouri, on August 13, 2019, and August 17, 2020, before installation of scour countermeasures

29. Map showing the bathymetric survey of the Missouri River channel near the main channel pier of structure A4649 on U.S. Highway 169 in Kansas City, Missouri, on October 23, 2020, after installation of scour countermeasures

30. Map showing the difference between surfaces created from bathymetric surveys of the Missouri River channel near the main channel pier of structure A4649 on U.S. Highway 169 in Kansas City, Missouri, on August 17 and October 23, 2020, before and after installation of scour countermeasures.

31. Map showing the bathymetric survey of the Missouri River channel near structure A4060 on State Highway 9 in Kansas City, Missouri, on August 13, 2019

32. Graph showing the frequency distribution of bed elevations for bathymetric survey-grid cells in 1-foot elevation bins on the Missouri River near structure A4060 on State Highway 9 in Kansas City, Missouri, on August 13, 2019, compared to previous surveys in 2010, 2011, and 2015

33. Diagram showing key features, substructural and superstructural details, and surveyed channel bed of structure A4060 on State Highway 9 crossing the Missouri River in Kansas City, Missouri.

34. Map showing the difference between surfaces created from bathymetric surveys of the Missouri River channel near structure A4060 on State Highway 9 in Kansas City, Missouri, on August 13, 2019, and June 3, 2015.

35. Map showing the difference between surfaces created from bathymetric surveys of the Missouri River channel near structure A4060 on State Highway 9 in Kansas City, Missouri, on August 13, 2019, and July 17, 2011

36. Map showing the difference between surfaces created from bathymetric surveys of the Missouri River channel near structure A4060 on State Highway 9 in Kansas City, Missouri, on August 13, 2019, and March 16, 2010.

37. Map showing bathymetry and vertically averaged velocities of the Missouri River channel near structure A4060 on State Highway 9 in Kansas City, Missouri, on August 13, 2019 
38. Map showing the bathymetric survey of the Missouri River channel near structure A7650 on Interstate 35 in Kansas City, Missouri, on August 14, 2019

39. Graph showing the frequency distribution of bed elevations for bathymetric survey-grid cells in 1-foot elevation bins on the Missouri River near structure A7650 on Interstate 35 in Kansas City, Missouri, on August 14, 2019, compared to previous surveys in 2011 and 2015

40. Diagrams showing key features, substructural and superstructural details, and surveyed channel bed of structure A7650 on Interstate 35 crossing the Missouri River in Kansas City, Missouri.

41. Map showing the difference between surfaces created from bathymetric surveys of the Missouri River channel near structure A7650 on Interstate 35 in Kansas City, Missouri, on August 14, 2019, and June 3, 2015.

42. Map showing the difference between surfaces created from bathymetric surveys of the Missouri River channel near structure A7650 on Interstate 35 in Kansas City, Missouri, on August 14, 2019, and July 17, 2011

43. Map showing bathymetry and vertically averaged velocities of the Missouri River channel near structure A7650 on Interstate 35 in Kansas City, Missouri, on August 14, 2019

44. Map showing the bathymetric survey of the Missouri River channel near structure A5817 on State Highway 269 in Kansas City, Missouri, on August 14, 2019 ....63

45. Graph showing the frequency distribution of bed elevations for bathymetric survey-grid cells in 1-foot elevation bins on the Missouri River near structure A5817 on State Highway 269 in Kansas City, Missouri, on August 14, 2019, compared to previous surveys in 2010, 2011, and 2015 .

46. Diagram showing key features, substructural and superstructural details, and surveyed channel bed of structure A5817 on State Highway 269 crossing the Missouri River in Kansas City, Missouri.

47. Map showing the difference between surfaces created from bathymetric surveys of the Missouri River channel near structure A5817 on State Highway 269 in Kansas City, Missouri, on August 14, 2019, and June 3, 2015.

48. Map showing the difference between surfaces created from bathymetric surveys of the Missouri River channel near structure A5817 on State Highway 269 in Kansas City, Missouri, on August 14, 2019, and July 18, 2011

49. Map showing the difference between surfaces created from bathymetric surveys of the Missouri River channel near structure A5817 on State Highway 269 in Kansas City, Missouri, on August 14, 2019, and March 17, 2010.

50. Map showing bathymetry and vertically averaged velocities of the Missouri River channel near structure A5817 on State Highway 269 in Kansas City, Missouri, on August 14, 2019

51. Map showing the bathymetric survey of the Missouri River channel near structure A0767 on Interstate 435 in Kansas City, Missouri, on August 14, 2019

52. Graph showing the frequency distribution of bed elevations for bathymetric survey-grid cells in 1-foot elevation bins on the Missouri River near structure A0767 on Interstate 435 in Kansas City, Missouri, on August 14, 2019, compared to previous surveys in 2010, 2011, and 2015

53. Diagram showing key features, substructural and superstructural details, and surveyed channel bed of structure A0767 on Interstate 435 crossing the Missouri River in Kansas City, Missouri. 
54. Map showing the difference between surfaces created from bathymetric surveys of the Missouri River channel near structure A0767 on Interstate 435 in Kansas City, Missouri, on August 14, 2019, and June 4, 2015.

55. Map showing the difference between surfaces created from bathymetric surveys of the Missouri River channel near structure A0767 on Interstate 435 in Kansas City, Missouri, on August 14, 2019, and July 18, 2011

56. Map showing the difference between surfaces created from bathymetric surveys of the Missouri River channel near structure A0767 on Interstate 435 in Kansas City, Missouri, on August 14, 2019, and March 17, 2010.

57. Map showing bathymetry and vertically averaged velocities of the Missouri River channel near structure A0767 on Interstate 435 in Kansas City, Missouri, on August 14, 2019

58. Map showing the bathymetric survey of the Missouri River channel near the main channel pier of structure A0767 on Interstate 435 in Kansas City, Missouri, on August 17, 2020, before installation of scour countermeasures

59. Map showing the difference between surfaces created from bathymetric surveys of the Missouri River channel near the main channel pier of structure A0767 on Interstate 435 in Kansas City, Missouri, on August 13, 2019, and August 17, 2020, before installation of scour countermeasures

60. Map showing the bathymetric survey of the Missouri River channel near the main channel pier of structure A0767 on Interstate 435 in Kansas City, Missouri, on 0 ctober 23,2020 , after installation of scour countermeasures.

61. Map showing the difference between surfaces created from bathymetric surveys of the Missouri River channel near the main channel pier of structure A0767 on Interstate 435 in Kansas City, Missouri, on August 17 and October 23, 2020, before and after installation of scour countermeasures

62. Map showing the bathymetric survey of the Missouri River channel near structures A4757 and L0568 on State Highway 291 near Kansas City, Missouri, on August 14, 2019

63. Graph showing the frequency distribution of bed elevations for bathymetric survey-grid cells in 1-foot elevation bins on the Missouri River near structures A4757 and L0568 on State Highway 291 near Kansas City, Missouri, on August 14, 2019, compared to previous surveys in 2010, 2011, and 2015

64. Diagram showing key features, substructural and superstructural details, and surveyed channel bed of structure A4757 on State Highway 291 crossing the Missouri River near Kansas City, Missouri.

65. Diagram showing key features, substructural and superstructural details, and surveyed channel bed of structure L0568 on State Highway 291 crossing the Missouri River near Kansas City, Missouri.

66. Map showing the difference between surfaces created from bathymetric surveys of the Missouri River channel near structures A4757 and L0568 on State Highway 291 near Kansas City, Missouri, on August 14, 2019, and June 4, 2015

67. Map showing the difference between surfaces created from bathymetric surveys of the Missouri River channel near structures A4757 and L0568 on State Highway 291 near Kansas City, Missouri, on August 14, 2019, and July 19, 2011

68. Map showing the difference between surfaces created from bathymetric surveys of the Missouri River channel near structures A4757 and L0568 on State Highway 291 near Kansas City, Missouri, on August 14, 2019, and March 18, 2010 
69. Map showing bathymetry and vertically averaged velocities of the Missouri River channel near structures A4757 and L0568 on State Highway 291 near Kansas City, Missouri, on August 14, 2019.

70. Graph showing average channel-bed and water-surface elevations near bridges on the Missouri River near Kansas City, Missouri, from surveys in 2010, 2011, 2015, and 2019

71. Graphs showing the comparison of frequency distribution and cumulative percentage of bed elevations for bathymetric survey-grid cells in 1-foot elevation bins from various surveys on the Missouri River near Kansas City, Missouri, in 2010, 2011, 2015, and 2019

\section{Tables}

1. Highway bridges crossing the Missouri River in and into Missouri in the Kansas City area, in downstream order

2. Results of a beam angle check from two check lines over a reference surface at Longview Lake near Kansas City, Missouri, on August 12, 2019.................................8

3. Patch test results at a few locations in Missouri from July 17 to September 4, 2019.......9

4. Uncertainty results for gridded bathymetric data at a 1.64-foot grid spacing from surveys on the Missouri River near Kansas City, Missouri, August 13-14, 2019....10

5. Bridge and survey information, and selected channel-bed elevations from surveys on the Missouri River near Kansas City, Missouri, August 13-14, 2019

6. Results near piers from surveys on the Missouri River near Kansas City, Missouri, August 13-14, 2019.

7. Summary information and bathymetric surface difference statistics from surveys on the Missouri River near Kansas City, Missouri, from August 13-14, 2019, and previous surveys

\section{Conversion Factors}

U.S. customary units to International System of Units

\begin{tabular}{lcl}
\hline \multicolumn{1}{c}{ Multiply } & By & \multicolumn{1}{c}{ To obtain } \\
\hline foot $(\mathrm{ft})$ & Length & meter $(\mathrm{m})$ \\
mile $(\mathrm{mi})$ & 0.3048 & kilometer $(\mathrm{km})$ \\
\hline & 1.609 & \\
\hline cubic yard $\left(\mathrm{yd}^{3}\right)$ & Volume & cubic meter $\left(\mathrm{m}^{3}\right)$ \\
\hline & 0.7646 & \\
\hline foot per second $(\mathrm{ft} / \mathrm{s})$ & Flow rate & meter per second $(\mathrm{m} / \mathrm{s})$ \\
cubic foot per second $(\mathrm{ft} 3 / \mathrm{s})$ & 0.3048 & cubic meter per second $\left(\mathrm{m}^{3} / \mathrm{s}\right)$ \\
\hline
\end{tabular}




\section{Datum}

Vertical coordinate information is referenced to the North American Vertical Datum of 1988 (NAVD 88).

Horizontal coordinate information is referenced to the North American Datum of 1983 (NAD 83).

\section{Supplemental Information}

In this report, the words "left" and "right" refer to directions that would be reported by an observer facing downstream.

Distance on the Missouri River is given in river miles (RMs) upstream from river mile 0 at the confluence with the Mississippi River at St. Louis, Missouri, at river mile 195.2 of the Upper Mississippi River.

Frequency is given in kilohertz $(\mathrm{kHz})$.

Data were collected, processed, and output in the International System of Units, and converted to U.S. customary units for presentation in the report at the request and for the convenience of the cooperator. 


\section{Abbreviations}

$\begin{array}{ll}\text { ADCP } & \text { acoustic Doppler current profiler } \\ \text { CUBE } & \text { Combined Uncertainty and Bathymetry Estimator } \\ \text { DEM } & \text { digital elevation model } \\ \text { DoD } & \text { digital elevation model of difference } \\ \text { GCD } & \text { Geomorphic Change Detection } \\ \text { GNSS } & \text { Global Navigation Satellite System } \\ \text { IHO } & \text { International Hydrographic Organization } \\ \text { IMU } & \text { inertial measurement unit } \\ \text { INS } & \text { inertial navigation system } \\ \text { MBES } & \text { multibeam echosounder } \\ \text { MBMS } & \text { multibeam echosounder mapping system } \\ \text { MMS } & \text { Mobile Mapping Suite } \\ \text { MoDOT } & \text { Missouri Department of Transportation } \\ \text { POS MV } & \text { Position Orientation Solution for Marine Vessels } \\ \text { RM } & \text { river mile } \\ \text { RTK } & \text { real-time kinematic } \\ \text { SBET } & \text { smoothed best estimate of trajectory } \\ \text { SOnar } & \text { sound navigation and ranging } \\ \text { TIN } & \text { triangulated irregular network } \\ \text { USGS } & \text { U.S. Geological Survey }\end{array}$




\title{
Bathymetric and Velocimetric Surveys at Highway Bridges Crossing the Missouri River near Kansas City, Missouri, August 2019, August 2020, and October 2020
}

\author{
By Richard J. Huizinga
}

\section{Abstract}

Bathymetric and velocimetric data were collected by the U.S. Geological Survey, in cooperation with the Missouri Department of Transportation, near 9 bridges at 8 highway crossings of the Missouri River near Kansas City, Missouri, on August 13-14, 2019. A multibeam echosounder mapping system was used to obtain channel-bed elevations for river reaches about 1,550 to 1,660 feet longitudinally and generally extending laterally across the active channel from bank to bank during moderate flood-flow conditions. These surveys indicated the channel conditions at the time of the surveys and provided characteristics of scour holes that may be useful in developing predictive guidelines or equations for scour holes. These data also may be useful to the Missouri Department of Transportation as a low to moderate flood-flow assessment of the bridges for stability and integrity issues with respect to bridge scour during floods.

Bathymetric data were collected around every pier that was in water, except around the nose of one pier that was surrounded by a persistent debris raft. Scour holes were present at most piers for which bathymetry could be obtained, except those on banks or surrounded by riprap. The observed scour holes at the surveyed bridges generally were examined with respect to shape and depth.

Comparisons between bathymetric surfaces from previous surveys and this study do not indicate any consistent correlation in channel-bed elevations with streamflow conditions at the times of the surveys. The predominant overall scour observed between the various surveys implies the channel bed in the 2019 surveys might have been rebounding from more substantial scour caused by the high streamflow earlier in March and June 2019, which was the highest streamflow since 1993. Pier size and nose shape had a substantial effect on the size of the scour hole observed at a given pier. Many of the piers at the Kansas City area bridges have wide or blunt noses caused by exposed footings, seal courses, or caissons, which resulted in large, deep scour holes at most piers. Several of the structures had piers that were skewed to primary approach flow; and, at most of the structures, the scour hole was deeper and longer on the side of the pier with impinging flow than the leeward side, with some amount of deposition on the leeward side, as typically has been observed at piers skewed to approach flow.

Limited additional bathymetric data were collected by the U.S. Geological Survey, in cooperation with Clarkson Construction, near the main channel piers of the U.S. Highway 169 (Broadway) and the Interstate 435 (Randolph) bridges on August 17 and October 23, 2020, to determine the channel-bed conditions before and after installation of scour countermeasures near those piers. Survey results from before and after installation of these countermeasures show these features had a substantial effect on mitigating the observed scour at these piers, particularly when compared to piers at other sites without such features.

\section{Introduction}

Scour in alluvial channels is the removal of channel-bed and bank material by flowing water and is the leading cause of bridge failures in the United States (Arneson and others, 2012). Scour at a bridge site is caused by short- and long-term geomorphic processes and the local effects from elements of the structure in or next to the waterway (Arneson and others, 2012; Huizinga and Rydlund, 2004). Because the effects of scour can be severe and dangerous, bridges and other structures over waterways are routinely assessed and inspected. Scour processes can be exacerbated during high-flow conditions because velocity and depth typically increase with increasing streamflow.

The Missouri Department of Transportation (MoDOT) is responsible for most of the transportation infrastructure in the State. A part of this responsibility is fulfilled through periodic inspections of highway structures, including bridges that span waterways. At most of these structures, all or most of the structure can be fully inspected from land or from personnel lift trucks deployed from the roadway of the structure; however, for structures over primary waterways, such as the Missouri and Mississippi Rivers, inspecting the underwater part of the bridge requires a different approach. 
The U.S. Geological Survey (USGS), in cooperation with MoDOT, began assessing scour at selected waterway crossings in Missouri in 1988 (Becker, 1994) and at waterway crossings throughout the State in 1991 (Huizinga and Rydlund, 2004). In 2007, the USGS, in cooperation with MoDOT, began determining channel bathymetry and monitoring for scour at bridges using single-beam echosounders and a multibeam echosounder mapping system (MBMS; Rydlund, 2009; Huizinga, 2010, 2011, 2012, 2013, 2014, 2015, 2016, 2017a, b, 2020a, b, c, d, e; Huizinga and others, 2010). The MBMS has been a useful tool not only in determining channel bathymetry but also in providing a medium- to high-resolution representation of bridge structural elements below the water line. In March 2010, 9 highway bridges at 7 crossings over the Missouri River near Kansas City, Missouri, were assessed using the MBMS (Huizinga, 2010). In October 2010, 12 highway bridges at 7 crossings over the Missouri and Mississippi Rivers near St. Louis, Mo., were assessed (Huizinga, 2011). During high-flow conditions in June-August 2011, many of the highway bridges and several of the railroad bridges along the entirety of the Missouri River downstream from Montana were assessed (Densmore and others, 2013; Dietsch and others, 2014), including the 37 highway bridges (at 28 crossings) over the Missouri River in and into Missouri (Huizinga, 2012). In April and May 2013, 10 highway bridges at 9 crossings over the Missouri River between Kansas City and St. Louis, Mo., were assessed as part of more routine, nonflood surveys at bridge sites in and into Missouri (Huizinga, 2014). In June 2014, 8 highway bridges at 7 crossings over the Missouri and Mississippi Rivers on the periphery of Missouri also were assessed as part of routine, nonflood surveys at bridge sites (Huizinga, 2015). A second round of routine, nonflood surveys at the highway bridges across the Missouri and Mississippi Rivers throughout Missouri began in 2015; the Kansas City area bridge surveys were completed in June 2015 (Huizinga, $2016,2020 b$ ), the St. Louis area bridge surveys were completed in May 2016 (Huizinga, 2017a, b), the bridge surveys between Kansas City and St. Louis were completed in May 2017 (Huizinga, 2020a, c), and the bridge surveys on the periphery of Missouri were completed in July-August 2018 (Huizinga, 2020d, e).

A third round of routine, nonflood surveys at the highway bridges across the Missouri and Mississippi Rivers throughout Missouri began in 2019. The study detailed in this report covers the surveys at the highway bridges across the Missouri River in the Kansas City area (fig. 1) and includes 9 bridges at 8 crossings (table 1). This report also provides details about two additional, limited surveys, completed in cooperation with Clarkson Construction, near the main channel pier of two sites in August and October 2020 before and after installation of scour countermeasures near these piers.

\section{Purpose and Scope}

The purpose of this report is to document the results of bathymetric and velocimetric surveys completed August 13-14, 2019, of the Missouri River channel near 9 highway bridges at 8 crossings in the Kansas City, Mo., area (fig. 1; table 1) using an MBMS and an acoustic Doppler current profiler (ADCP). Special bathymetric surveys before and after installation of scour countermeasures near the main channel pier of two of the sites in August and October 2020 also are documented. Equipment and methods used and results obtained are described. The results obtained from the bathymetric and velocimetric surveys of the channel document the channel-bed conditions and velocity distribution at the time of the surveys and provide characteristics of scour holes that may be useful in developing predictive guidelines or equations for scour holes. These data also may be used by MoDOT as a low to moderate flood-flow comparison to help assess the bridges for stability and integrity issues with respect to bridge scour. Comparison of results to previous surveys at the sites (Huizinga, 2010, 2012, 2016, 2020a) also are provided.

\section{Description of Study Area}

The study area for this report is the Missouri River in and near Kansas City, Mo. (fig. 1). The Missouri River flows through the Kansas City area from west to east, meandering across the floodplain. The river is highly channelized in the Kansas City area; rock revetment and spur dikes are along the banks to maintain the channel alignment, and levees and floodwalls are on the upper banks to limit flooding in the industrial, commercial, and agricultural areas on the floodplains. The site numbering sequence used in Huizinga (2012) is used in this report for consistency and comparability.

\section{Description of Streamflow Conditions}

Data from the streamflow-gaging station (hereinafter referred to as "streamgage") on the Missouri River at Kansas City, Mo. (station 06893000; U.S. Geological Survey, 2020; fig. 1), indicated the Missouri River was in a trough between minor flood rises when the sites were surveyed August 13-14, 2019 (fig. 2A); however, the trough happened during generally higher summer streamflows that lasted from mid-March to past the end of the water year in September (fig. 2B). Moderate streamflows of more than 110,000 cubic feet per second $\left(\mathrm{ft}^{3} / \mathrm{s}\right)$ were observed throughout the spring and summer, compared to $45,000-50,000 \mathrm{ft}^{3} / \mathrm{s}$ observed during the late winter trough in early March. The streamflow on the Missouri River as measured at the Kansas City streamgage ranged from about 122,000 to $137,000 \mathrm{ft}^{3} / \mathrm{s}$ during the surveys. This streamflow range has a daily exceedance range of about 5 to 6 percent (U.S. Geological Survey, 2021) and is slightly less than the 50-percent annual exceedance probability (2-year recurrence interval) flood of 142,000 ft $3 / \mathrm{s}$ (U.S. Army Corps 

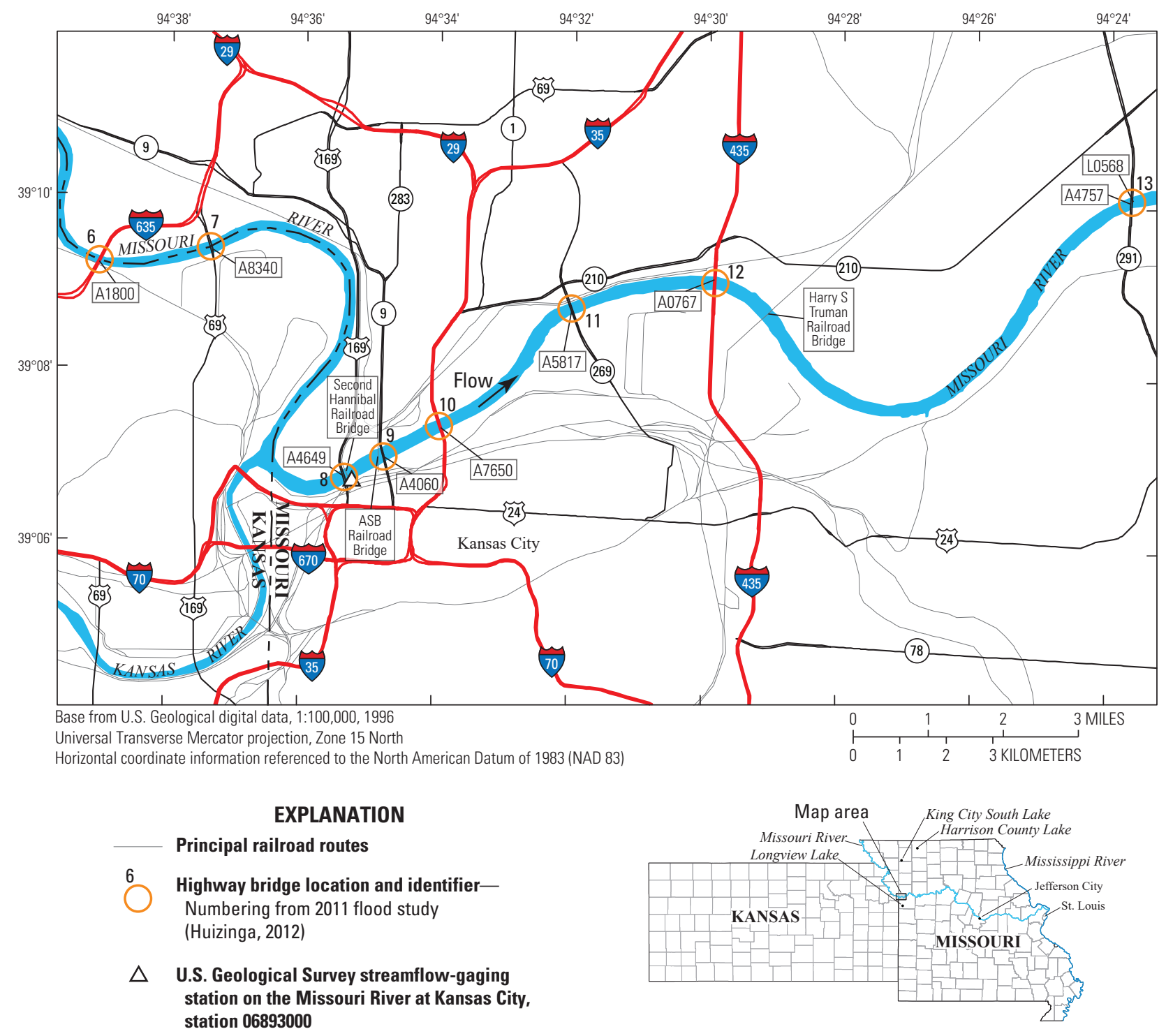

Figure 1. Location of highway bridges crossing the Missouri River in and into Missouri in the Kansas City, Missouri, area.

of Engineers, 2004, plate E-20). Daily exceedance probabilities were computed using daily streamflow from 1957 to 2020 (U.S. Geological Survey, 2021).

Streamflow conditions in these daily and annual exceedance ranges are in the low to moderate flood-flow regime. In an analysis of real-time scour monitoring data at Jefferson City, Mo., Huizinga (2014) noted that substantial pier scour begins soon after the onset of hydrograph rise (substantial rise of 8 feet [ft] or more), although the scour often does not reach maximum depth until the peak stage is reached or sometime thereafter (see fig. 35 in Huizinga, 2014). Although the streamflow conditions during these surveys was not at the peak streamflow for the summer season, several peaks had occurred earlier in the year (fig. 2), and streamflow was substantially higher than base flow based on the daily exceedance values. Furthermore, the peak streamflow of $308,000 \mathrm{ft}^{3} / \mathrm{s}$ on June 2, 2019, a streamflow that is in the 2- to 5-percent annual exceedance probability (20- to 50-year recurrence interval) range (U.S. Army Corps of Engineers, 2004, plate E-20), was the highest streamflow since 1993 and is higher than flows observed in 2011 (U.S. Geological Survey, 2020). Although the scour scenario captured at the sites in this study likely does not represent the maximum scour potential that might have been observed immediately after the peak streamflow in early June, the cumulative information gathered at the sites during the course of multiple surveys in 2010, 2011, 2016, and 2019 remains useful for determining scour for a variety of streamflow conditions and flood durations.

Special surveys were conducted at two of the sites in August and October 2020. The streamflow on the Missouri River as measured at the Kansas City streamgage was about $61,000 \mathrm{ft}^{3} / \mathrm{s}$ during the survey on August 17, 2020, and was about 46,200 ft³/s during the survey on October 23, 2020. These streamflows have a daily exceedance of about 35 and 
Table 1. Highway bridges crossing the Missouri River in and into Missouri in the Kansas City area, in downstream order.

[KDOT, Kansas Department of Transportation; Mo., Missouri; IS, Interstate highway; S, southbound; Kans., Kansas; N, northbound; MoDOT, Missouri Department of Transportation; --, not known/applicable; US, U.S. highway; MO, Missouri State highway]

\begin{tabular}{|c|c|c|c|c|c|c|c|c|c|}
\hline $\begin{array}{c}\text { Site } \\
\text { num- } \\
\text { ber } \\
\text { (fig. 1) }\end{array}$ & $\begin{array}{l}\text { Primary } \\
\text { agency }\end{array}$ & $\begin{array}{l}\text { Structure } \\
\text { number }\end{array}$ & Local name & County, State & Route & $\begin{array}{l}\text { River } \\
\text { mile }^{\mathrm{a}}\end{array}$ & $\begin{array}{c}\text { Surveyed } \\
\text { as part } \\
\text { of this } \\
\text { study }\end{array}$ & Remarks & Figures \\
\hline 6 & MoDOT & A 1800 & Riverside & Platte, Mo. & IS 635 & 374.1 & Yes & -- & $1,6-12,1.1$ \\
\hline 7 & MoDOT & A8340 & Fairfax & Platte, Mo. & US 69 & 372.6 & Yes & $\begin{array}{r}\text { Replaced K0456/ } \\
\text { A0450 in } 2016\end{array}$ & $1,13-19,1.2$ \\
\hline 8 & MoDOT & A4649 & Buck O’Neil & Clay, Mo. & US 169 & 366.2 & Yes & -- & $\begin{array}{l}1,20-30 \\
1.3-1.4\end{array}$ \\
\hline 10 & MoDOT & A7650 & $\begin{array}{l}\text { Christopher } \\
\text { Bond }\end{array}$ & Clay, Mo. & IS 35 & 364.7 & Yes & -- & $1,38-43,1.6$ \\
\hline 11 & MoDOT & A5817 & Chouteau & Clay, Mo. & MO 269 & 362.3 & Yes & -- & $1,44-50,1.7$ \\
\hline 12 & MoDOT & A0767 & Randolph & Clay, Mo. & IS 435 & 360.3 & Yes & -- & $\begin{array}{r}1,51-61 \\
1.8-1.9\end{array}$ \\
\hline \multirow[t]{2}{*}{13} & MoDOT & A4757 & Courtney & Jackson, Mo. & MO $291 \mathrm{~S}$ & 352.7 & Yes & $\begin{array}{l}\text { Dual bridge crossing } \\
\text { with L0568 }\end{array}$ & $\begin{array}{l}1,5,62-69 \\
1.10\end{array}$ \\
\hline & & L0568 & Courtney & Jackson, Mo. & MO $291 \mathrm{~N}$ & & Yes & $\begin{array}{l}\text { Dual bridge crossing } \\
\text { with A4757 }\end{array}$ & $\begin{array}{l}1,5,62-69 \\
1.10\end{array}$ \\
\hline
\end{tabular}

aRiver mile is the distance upstream from the confluence of the Missouri River with the Mississippi River at St. Louis, Mo. (fig. 1).

bShown for consistency with previous survey; not included in this study.

55 percent, respectively (daily exceedance probabilities were computed using daily streamflow from 1957 to 2020; U.S. Geological Survey, 2021), and are substantially less than the 50-percent annual exceedance probability (2-year recurrence interval) flood of 142,000 ft $3 / \mathrm{s}$ (U.S. Army Corps of Engineers, 2004, plate E-20). Streamflow conditions in these daily and annual exceedance ranges are in the nonflood regime.

\section{Description of Equipment and Basic Processing}

The bathymetry of the Missouri or Mississippi River at each of the bridges was determined using a high-resolution MBMS. The various components of the MBMS used for this study are as described in reports about studies on the Missouri and Mississippi Rivers in Missouri (Huizinga, 2010, 2011, 2012, 2013, 2014, 2015, 2016, 2017a; 2020a, e; Huizinga and others, 2010) and on the Missouri and Yellowstone Rivers in North Dakota (Densmore and others, 2013). The survey methods used to obtain the data were similar to these previous studies, as were the measures used to ensure data quality. A brief description of the equipment follows; a more-complete description of the various system components and methods used in this study are available in the previous reports by Huizinga (2010), Huizinga and others (2010), and Densmore and others (2013).

An MBMS is an integration of several individual components: the multibeam echosounder (MBES), an inertial navigation system (INS), and a data-collection and dataprocessing computer. The MBES that was used for the 2019 surveys is the Norbit iWBMSh (fig. 3), which operated at a frequency of 400 kilohertz (kHz). The iWBMSh is similar in operation to the MBES systems used in other previous studies in the Kansas City area, except that it has a curved receiver array, which enables bathymetric data to be collected throughout a sound navigation and ranging (sonar) swath range of 210 degrees. Optimum data usually are collected in a swath of less than 160 degrees ( 80 degrees on each side of nadir, or straight down below the MBES); nevertheless, the swath can be electronically rotated to either side of nadir, enabling data along sloping banks to be captured up to a depth just below 

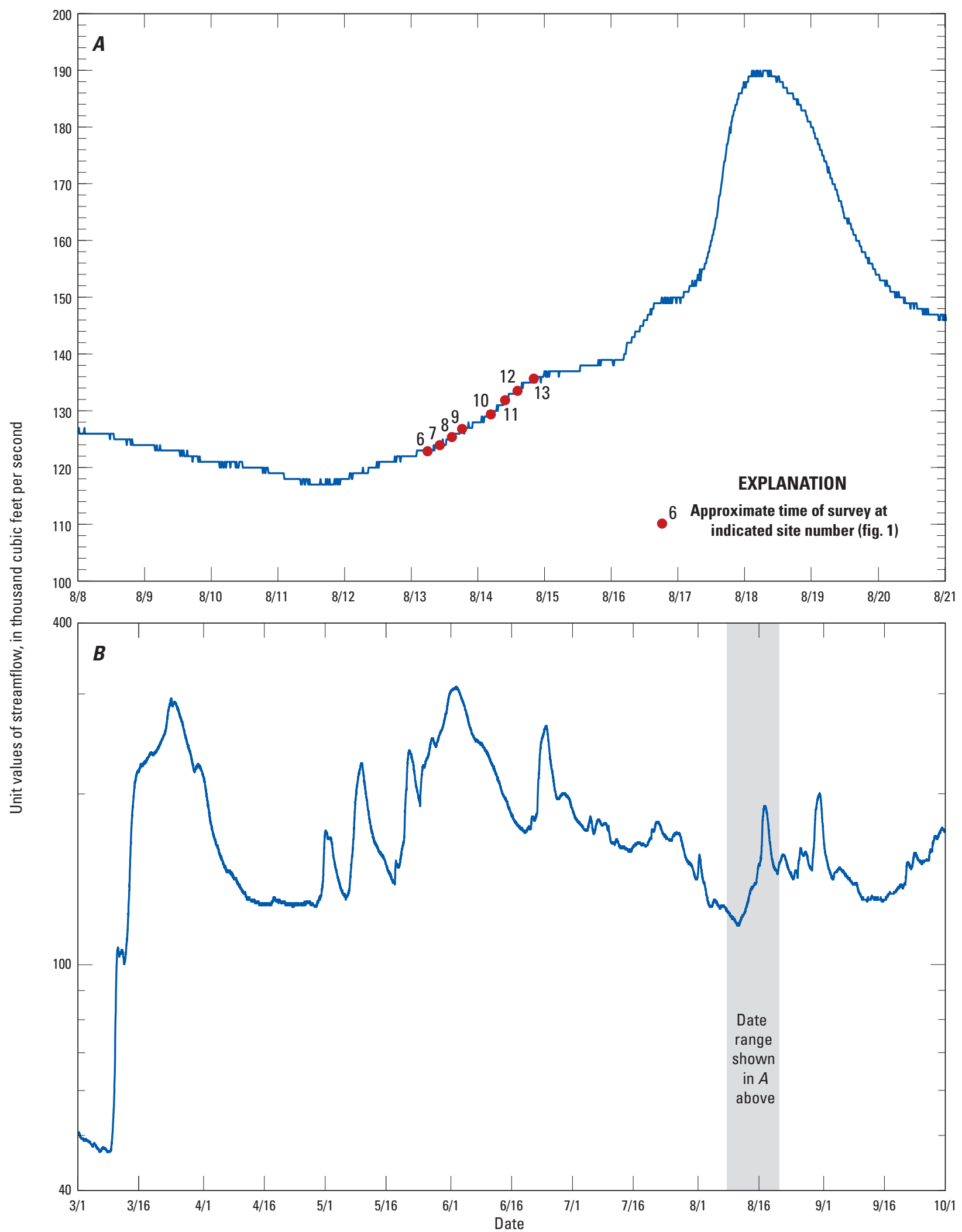

Figure 2. Unit values of streamflow (15-minute interval) from the streamflow-gaging station on the Missouri River at Kansas City, Missouri (station 06893000; U.S. Geological Survey, 2020). A,August 8-12, 2019. B, March 1 through September 30, 2019. 

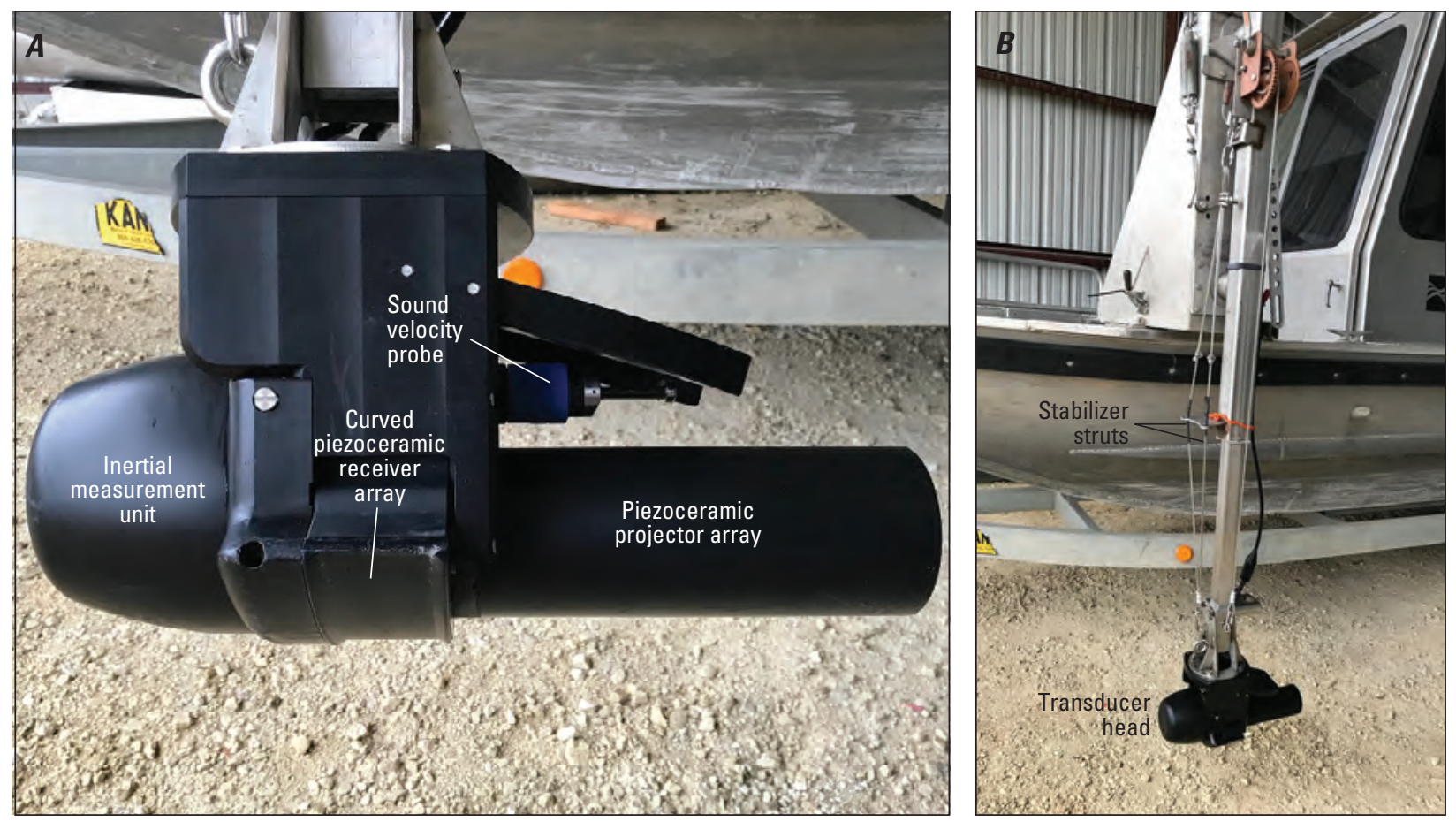

Figure 3. The Norbit iWBMSh multibeam echosounder. Photographs by Richard J. Huizinga, U.S. Geological Survey. A, Viewed from the side. $B$, Mounted on the port side of the U.S. Geological Survey boat.

the water surface. The Norbit iWBMSh has a tightly coupled INS, the Applanix Position Orientation Solution for Marine Vessels (POS MV) OceanMaster system, consisting of an inertial motion unit on the sonar head (fig. $3 \mathrm{~A}$ ) and two Global Navigation Satellite System (GNSS) antennae. The INS provides position in three-dimensional space and measures the pitch, roll, yaw, and heading of the vessel (and, thereby, the MBES) to accurately position the data received by the MBES. Real-time kinematic (RTK) differential corrections for the INS came from cellular communication with the MoDOT GNSS real-time network for the navigation and tide solution during the 2019 surveys.

As in previous surveys (Huizinga, 2010, 2011, 2012, 2013, 2014, 2015, 2016, 2017a, b, 2020a, b, c, d, e), the navigation information from the 2019 surveys was postprocessed using the POSPac Mobile Mapping Suite (MMS) software (Applanix Corporation, 2017) to mitigate the effects of degraded positional accuracy of the vessel while near or under a bridge. The POSPac MMS provides tools to identify and compensate for sensor and environmental errors and computes an optimally blended navigation solution from the GNSS and inertial measurement unit (IMU) raw data. The blended navigation solution (called a "smoothed best estimate of trajectory" or "SBET" file) generated by postprocessing the navigation data was applied to the survey at a given bridge to minimize the effects of the GNSS outages while surveying under the bridges.
The data from the MBES and INS components were processed and integrated into a cohesive dataset for cleanup and visualization. A computer onboard the survey vessel ran the HYPACK/HYSWEEP data acquisition software (HYPACK, Inc., 2018) that was used to prepare for the bathymetric surveys and collect the survey data. After completing the surveys, the acquired depth data were further processed to remove data spikes and other spurious points in the multibeam swath trace, georeferenced using the navigation and position solution data from the SBET file from the POSPac MMS, and visualized in HYPACK/HYSWEEP as a gridded bathymetric surface or a point cloud.

Information about the velocity of the river at various points throughout each study reach were collected using an ADCP, similar to recent previous studies by Huizinga (2012, 2013, 2014, 2015, 2016, 2017a, b, 2020a, b, c, d, e). A Teledyne RD Instruments Rio Grande ADCP operating at $600 \mathrm{kHz}$ was used to obtain velocities at 1.64-ft increments, or "bins," throughout the water column. The Rio Grande $600-\mathrm{kHz}$ ADCP operates in depths from 2.3 to $230 \mathrm{ft}$ and determines the velocity of the water by measuring the Doppler shift of an acoustic signal reflected from various particles suspended in the water (Mueller and others, 2013). By measuring the Doppler shift in four different beam directions, the velocity of the water in each bin can be determined in three dimensions. 


\section{Basic Description of Methods}

The methods used to acquire and ensure the collection of quality data were the same as those used in previous studies using the MBES (methods are detailed in Huizinga and others, 2010; Huizinga, 2010, 2012). A brief summary of - and differences from - these methods are highlighted below.

\section{Surveying Methods}

Generally, the surveyed area extended across the active channel from bank to bank, as in the previous studies on the Missouri River in the Kansas City area (Huizinga, 2010, 2012, 2016). The surveyed reaches were 1,550 to $1,660 \mathrm{ft}$ long in the direction of flow, positioned so that the surveyed highway bridges were about one-third to one-half of the total length from the upstream boundary, generally using about the same upstream and downstream boundaries as used in the 2011 flood study on the Missouri River (Huizinga, 2012). The upstream and downstream boundaries of the surveyed areas were assumed to be beyond the substantial hydraulic effects (wake vortices and shear flow) of the bridge structures.

As in previous studies, bathymetric data were obtained along longitudinal transect lines, and each survey was designed such that there was overlap of the survey swaths to attempt to ensure complete coverage of the channel bed and minimize sonic "shadows" (Huizinga and others, 2010). Substantial overlap was achieved for many of the surveyed swaths, except in shallow areas near the channel banks or spur dikes and near in-flow structures or debris rafts. Areas near the bridge piers and along the banks also were surveyed in an upstream direction with the MBES swath electronically tilted to port or starboard to increase the acquisition of bathymetric data higher on the banks and the sides of the piers. The electronically tilted swath generally was 120 degrees wide, extending from 10 degrees above horizontal on the bank-ward or pier-ward side of the survey vessel to 20 degrees past nadir below the vessel.

After completing the bathymetric survey with the MBMS at a given site, the velocity data were obtained with the ADCP on seven lateral sections across the channel within the study area. The position and speed of the boat was determined using a differential GNSS receiver mounted on a pole directly above the ADCP. The bottom-track reference method for determining boat speed was anticipated to be unusable because of moving channel-bed material, so the boat velocity was determined using the GNSS essential fix data (the NMEA-0183 GGA string [shorthand for the \$GPGGA standard output format for GNSS essential fix data defined by the National Marine Electronics Association 0183 standard that includes information on the three-dimensional location and accuracy of the GNSS receiver; National Marine Electronics Association, 2002]) from the differential GNSS receiver. The distance between the velocity section lines generally was about $260 \mathrm{ft}$. Three sections were upstream and four sections were downstream from the bridge being surveyed. Each section line was traversed in each direction across the river. The reported velocity values are the average from the two traverses of a given section line, computed using averaging algorithms from the Velocity Mapping Toolbox (Parsons and others, 2013). Streamflow for a site was computed as the average of the streamflows from reciprocal pairs (two transects per section line) at the various sections in the reach. Generally, measured streamflow for an individual transect was within 5 percent of the average.

\section{Survey Quality-Assurance/Quality-Control Measures}

A quality-assurance plan has been established for streamflow measurements using ADCPs that includes several instrument diagnostic checks and calibrations. These standard operating procedures were followed when acquiring the velocity profile data for these surveys, including a moving-bed test and paired ADCP measurements at each transect to mitigate directional bias. For a detailed discussion of these procedures, see Mueller and others (2013).

For the MBMS, the principal quality-assurance measures were assessed in real time during the survey. The MBMS operator continuously assessed the quality of the collected data during the survey by making visual observations of crosstrack swath shape (such as convex, concave, or skewed bed returns in flat, smooth bottoms), noting data-quality flags and alarms from the MBES and the INS, and noting comparisons between adjacent overlapping swaths. In addition to the realtime quality-assurance assessments during the survey, beam angle checks and a suite of patch tests were executed to ensure quality data were acquired from the MBMS for the 2019 surveys. The beam angle test and patch tests were completed at Longview Lake near Kansas City, Mo. (fig. 1).

\section{Beam Angle Check}

A beam angle check is used to determine the accuracy of the depth readings obtained by the outer beams (greater than 25 degrees from nadir [vertical]) of the MBES (U.S. Army Corps of Engineers, 2013), which may change with time as a result of inaccurate sound velocities, physical configuration changes, and overall depth being surveyed. The HYPACK/ HYSWEEP software has a utility that develops a statistical assessment of the quality of the outer beams compared to a reference surface (HYPACK, Inc., 2018). On August 12, 2019, a reference surface was surveyed for a part of Longview Lake near Kansas City, Mo. (fig. 1), and check lines were run across the reference surface. Included with the measurement was a sound-velocity profile cast to document and quantify any stratification in the water column near the reference surface. The results of this beam angle check (table 2) were within the recommended performance standards used by the U.S. Army Corps of Engineers for hydrographic surveys for 
Table 2. Results of a beam angle check from two check lines over a reference surface at Longview Lake near Kansas City, Missouri, on August 12, 2019.

$[<$, less than; --, no data $]$

\begin{tabular}{ccccc}
\hline $\begin{array}{c}\text { Beam } \\
\text { angle } \\
\text { limit, in } \\
\text { degrees }\end{array}$ & $\begin{array}{c}\text { Maximum } \\
\text { outlier, } \\
\text { in feet }\end{array}$ & $\begin{array}{c}\text { Average } \\
\text { difference, } \\
\text { in feet }\end{array}$ & $\begin{array}{c}\text { Standard } \\
\text { deviation, } \\
\text { in feet }\end{array}$ & $\begin{array}{c}\text { 95-percent } \\
\text { confidence, } \\
\text { in feet }\end{array}$ \\
\hline \multicolumn{5}{c}{ Beam angle check results } \\
\hline 0 & 0.36 & 0.00 & 0.10 & 0.20 \\
5 & 0.49 & 0.03 & 0.10 & 0.20 \\
10 & 0.49 & 0.07 & 0.13 & 0.23 \\
15 & 0.49 & 0.07 & 0.13 & 0.26 \\
20 & 0.62 & 0.10 & 0.13 & 0.26 \\
25 & 0.59 & 0.07 & 0.13 & 0.26 \\
30 & 0.66 & 0.10 & 0.13 & 0.26 \\
35 & 0.72 & 0.10 & 0.13 & 0.26 \\
40 & 0.62 & 0.13 & 0.13 & 0.26 \\
45 & 0.72 & 0.10 & 0.13 & 0.26 \\
50 & 0.92 & 0.03 & 0.13 & 0.26 \\
55 & 1.28 & -0.03 & 0.20 & 0.36 \\
60 & 2.10 & -0.13 & 0.26 & 0.52 \\
65 & 2.03 & -0.23 & 0.33 & 0.62 \\
70 & 1.57 & -0.36 & 0.20 & 0.39 \\
\hline \multicolumn{5}{c}{ Performance standards ${ }^{\mathrm{a}}$} \\
\hline-- & 1.00 & $<0.20$ & -- & $<0.80$ \\
-- & Met, angle & Met, angle & - & Met \\
\hline \multicolumn{5}{c}{$<55$} \\
\hline
\end{tabular}

aPerformance standard check values are from U.S. Army Corps of Engineers (2013, table 3-1) for soft sand/silt bottoms.

all the representative angles less than 55 degrees (U.S. Army Corps of Engineers, 2013), permitting the use of the central 110 degrees of the sonar swath with confidence.

Ideally, the average depth of the reference surface used in the beam angle check would be equal to or greater than the depth in the area being surveyed. The depth of the Missouri River in each study reach generally is unknown before each survey because of the dynamic nature of the channel bed and streamflow conditions; however, the average depth of the reference surface (about $70 \mathrm{ft}$ ) was expected to be substantially greater than the average depth observed in the 2019 surveys because the average depths observed during the 2011 flood surveys in the Kansas City area were less than $40 \mathrm{ft}$ (the average depth is the difference between the average water-surface elevation and average channel-bed elevation in table 5 of Huizinga [2012]). As described in the "Surveying Methods" section earlier in this report, areas with depths greater than the average depths generally had substantial overlap of the surveyed swath with adjacent swaths. Data from the outer beams in these areas were either verified or removed to mitigate any detrimental effects caused by beam angle inaccuracies.

\section{Patch Tests}

Patch tests are a series of dynamic calibration tests that are used to check for subtle variations in the orientation and timing of the MBES with respect to the INS and real-world coordinates. The patch tests are used to determine timing offsets caused by latency between the MBES and the INS, and to determine angular offsets to roll, pitch, and yaw caused by the alignment of the transducer head (fig. 4). These offsets have been observed to be essentially constant for a given survey, barring an event that causes the mount to change such as striking a floating or submerged object (Huizinga, 2010, 2011, 2012, 2014, 2015, 2016, 2017a, 2020a, e). The offsets determined in the patch test are applied when processing the data collected during a survey.

Patch tests were completed before and after the 2019 surveys at three lakes in Missouri (table 3). Although the MBES had several minor strikes of floating debris at various times during the 2019 surveys, there were no apparent changes to the roll, pitch, or yaw angles from the beginning to the end of the surveys.

For this study, there was no measured timing offset ( $\Delta t=0$; table 3, fig. 4), which is consistent with latency test results for this boat and similar equipment configurations used in other surveys (Huizinga, 2010, 2011, 2012, 2013, 2014, 2015, 2016, 2017a, 2020a, e; Huizinga and others, 2010). The measured angular offset for pitch was 0 degree (table 3 ). The measured offset for yaw changed from 0 to 0.50 degree (table 3 ), which is likely the result of a relatively major strike of a submerged tree at Harrison County Lake; therefore, the yaw of the Kansas City area surveys was not affected. The measured angular offset for roll seemed to be -0.37 degree just before the Kansas City area surveys based on the results at Longview Lake (table 3); however, the measured angular offset for roll was -0.30 degree for the patch tests before and after the Kansas City area surveys (table 3 ). Furthermore, using a roll angle offset of -0.37 degree during processing of the Kansas City area bridge surveys indicated this offset was incorrect. Therefore, a roll angle offset of -0.30 degree was used for the Kansas City area bridge surveys with better overall results. It was noted in the earliest work with the MBMS in Missouri (Huizinga, 2010) that a sensitivity analysis of the four offsets implied that the ultimate position of surveyed points in three-dimensional space was least sensitive to the angular offset for yaw, whereas it was most sensitive to the angular offset for roll.

The bathymetric data were processed to apply the offsets determined from the patch tests and to remove data spikes and other spurious points in the multibeam swaths through the use of automatic filters and manual editing. The bathymetric data were then projected to a three-dimensional grid at a resolution of $1.64 \mathrm{ft}$ using the Combined Uncertainty and 


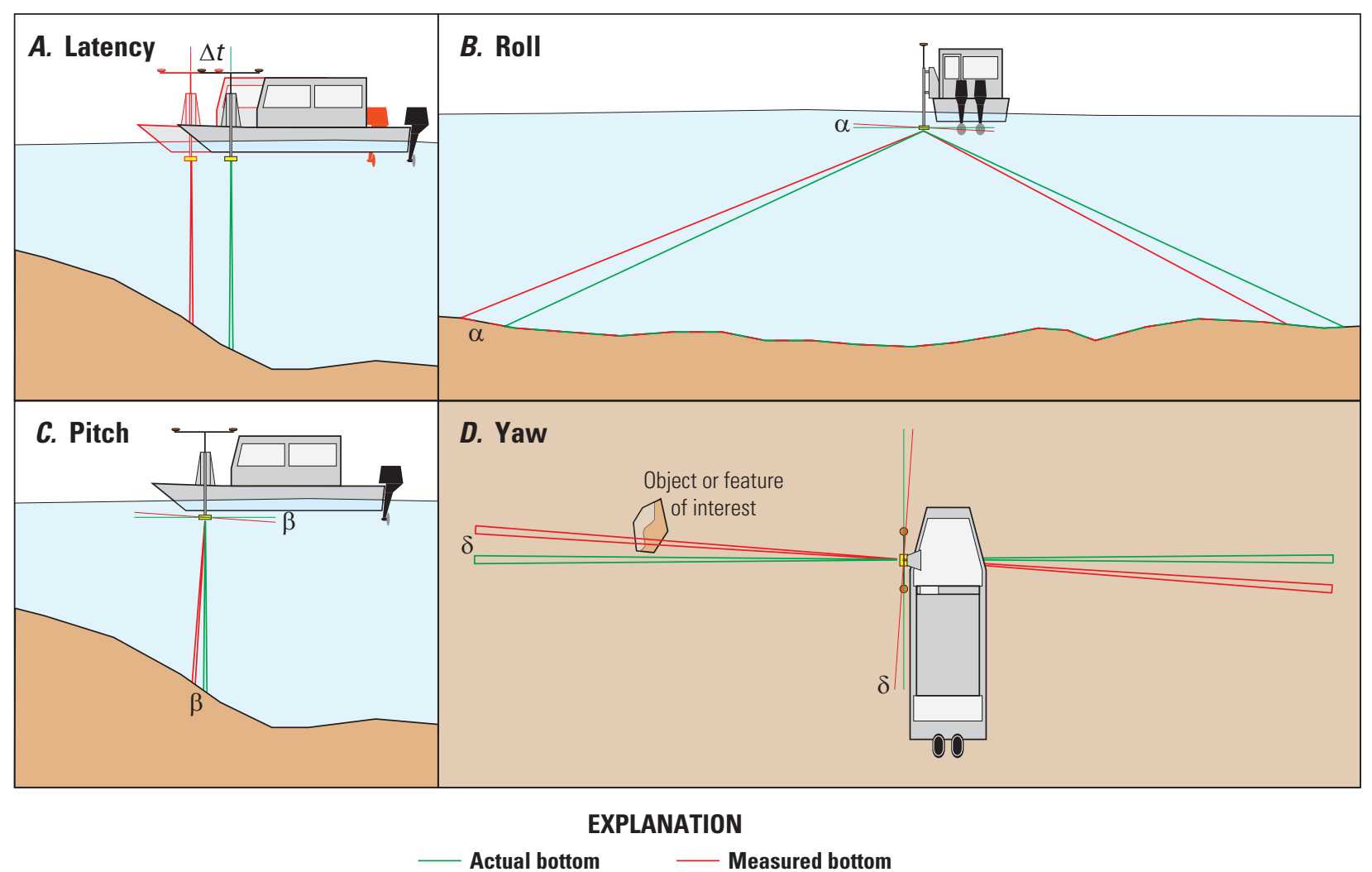
$\Delta t$ Timing offset for latency between the multibeam echosounder and Global Navigation
Satellite System components of the inertial navigation system
$\alpha$ Angular offset for roll of the transducer head along the longitudinal axis of the boat
$\beta$ Angular offset for pitch of the transducer head along the lateral axis of the boat
$\delta$ Angular offset for yaw of the transducer head about the vertical axis

Figure 4. Generalized effects on data from a multibeam echosounder. $A$, Timing offset for latency. $B$, Angular offset for roll. $C$, Angular offset for pitch. $D$, Angular offset for yaw.

Table 3. Patch test results at a few locations in Missouri from July 17 to September 4, 2019.

[Dates are shown as month/day/year]

\begin{tabular}{lccccc}
\hline Date of test & $\begin{array}{c}\text { Timing offset, } \\
\text { in seconds }\end{array}$ & $\begin{array}{c}\text { Angular offset } \\
\text { for roll, } \\
\text { in degrees }\end{array}$ & $\begin{array}{c}\text { Angular offset } \\
\text { for pitch, } \\
\text { in degrees }\end{array}$ & $\begin{array}{c}\text { Angular offset } \\
\text { for yaw, } \\
\text { in degrees }\end{array}$ & Location (fig. 1) \\
\hline $07 / 17 / 19$ & 0 & -0.30 & 0 & 0 & King City South Lake near King City, Missouri \\
$08 / 12 / 19$ & 0 & -0.37 & 0 & 0 & Longview Lake near Kansas City, Missouri \\
$09 / 04 / 19$ & 0 & -0.30 & 0 & 0.50 & Harrison County Lake near Bethany, Missouri \\
\hline
\end{tabular}

Bathymetry Estimator (CUBE) method (Calder and Mayer, 2003), as implemented in the MBMax processing package of the HYPACK/HYSWEEP software (HYPACK, Inc., 2018) and used to generate a gridded raster surface of the channel bed (and associated uncertainty) near each bridge (hereinafter referred to as a "bathymetric surface") using ArcGIS (Esri, 2020).

\section{Uncertainty Estimation}

Similar to the previous studies of bathymetry in Missouri (Huizinga, 2010, 2011, 2012, 2013, 2014, 2015, 2016, 2017a, b, 2020a, b, c, d, e), uncertainty in the surveys was estimated by computing the uncertainty for each survey-grid cell in the bathymetric surface of each survey area using the CUBE method (Calder and Mayer, 2003) as implemented in the MBMax processing package of the HYPACK/HYSWEEP 
software (HYPACK, Inc., 2018). The CUBE uncertainty is a measure of the variability of the individual points in the cell used to determine the CUBE-derived elevation for the cell. Statistics of CUBE uncertainty for each of the survey areas are shown in table 4, and an example of the spatial distribution of CUBE uncertainty typically observed in the survey data is shown in figure 5 for the bathymetric data at structures A4757 and L0568 on State Highway 291. The uncertainty data were output and combined with the three-dimensional bathymetry data and are included with metadata in the USGS data release associated with this study (Huizinga, 2021).

The largest uncertainty in this group of surveys was $4.00 \mathrm{ft}$ (table 4); however, as noted in previous studies, uncertainty values of this magnitude typically happened near high-relief features, such as the front or side of a pier footing (fig. 5). More than 98 percent of the uncertainty values at all the sites were less than $0.50 \mathrm{ft}$ (table 4), which is within the specifications for a "Special Order" survey, the moststringent survey standard of the International Hydrographic Organization (IHO; International Hydrographic Organization, 2008). As noted in previous surveys with this type of equipment (see, for example, Huizinga, 2012, 2016), the uncertainty values were larger near moderate-relief features (banks, spur dikes, rock riprap and outcrops, and scour holes near piers). Occasionally, the uncertainty values also were larger $(1.00 \mathrm{ft}$ or greater) in the outermost beam extents of the multibeam swath in the overlap with an adjacent swath, particularly when the MBES head was electronically tilted for the survey lines along the banks or near the piers. Overlapping adjacent swaths in the channel thalweg (the line of maximum depth in the channel) also can display larger uncertainty values because substantial bed movement can happen between survey passes (fig. 5). More than 96 percent of the uncertainty values were less than $0.25 \mathrm{ft}$, and more than 50 percent of the uncertainty values were less than $0.10 \mathrm{ft}$ (table 4). The tops of bridge substructural elements (pier footings and seal courses) typically had uncertainty values of less than $0.10 \mathrm{ft}$.

The uncertainty of the gridded data computed using the CUBE method has been decreasing with time compared to previous surveys (see table 4 in previous studies; Huizinga, 2012 , 2016). The decrease in uncertainty primarily is the result of improvements in data-collection equipment and methods. The Norbit iWBMSh used in these surveys has the IMU attached directly to the sonar head in what is referred to as a "tightly coupled" configuration, which decreases some of the uncertainty by reducing the lever arm length (and therefore the potential movement) between the sonar and IMU. The ability to electronically tilt the sonar swath substantially reduces the time between when unrotated, down-looking data and rotated, side-looking data are collected, which reduces the uncertainty of the data in the swath overlap zone that might otherwise experience more substantial bed movement.

The survey at structures A4757 and L0568 on State Highway 291 had the third-highest maximum value of uncertainty, as well as the lowest percentage of bathymetry points with an uncertainty of less than the various thresholds (table 4). The survey was obtained with relatively smooth longitudinal swaths (fig. 5), which was the case at nearly all the sites surveyed in this study. The primary anomalies at this site were observed along the banks, where the sonar was used in an electronically tilted configuration to extend the potential coverage in these areas, resulting in high uncertainty values. Secondary anomalies at this site were in the downstream midchannel area where thalweg migration and insufficient overlap of the swath outer beams resulted in high uncertainty values. Generally, the magnitude and distribution of uncertainty observed at this site are representative of those observed at all the other surveyed sites.

Table 4. Uncertainty results for gridded bathymetric data at a 1.64-foot grid spacing from surveys on the Missouri River near Kansas City, Missouri, August 13-14, 2019.

[MoDOT, Missouri Department of Transportation]

\begin{tabular}{|c|c|c|c|c|c|c|c|c|c|}
\hline \multirow{2}{*}{$\begin{array}{c}\text { Site } \\
\text { number } \\
\text { (fig. 1) }\end{array}$} & \multirow{2}{*}{$\begin{array}{c}\text { MoDOT } \\
\text { structure } \\
\text { number }\end{array}$} & \multirow{2}{*}{$\begin{array}{l}\text { Maximum } \\
\text { value of } \\
\text { uncertainty, } \\
\text { in feet }\end{array}$} & \multirow{2}{*}{$\begin{array}{c}\text { Average } \\
\text { value of } \\
\text { uncertainty, } \\
\text { in feet }\end{array}$} & \multirow{2}{*}{$\begin{array}{c}\text { Median } \\
\text { value of } \\
\text { uncertainty, } \\
\text { in feet }\end{array}$} & \multirow{2}{*}{$\begin{array}{c}\text { Standard } \\
\text { deviation of } \\
\text { uncertainty, } \\
\text { in feet }\end{array}$} & \multicolumn{4}{|c|}{$\begin{array}{c}\text { Percentage of bathymetry points with uncertaint } \\
\text { value less than a given threshold }\end{array}$} \\
\hline & & & & & & 1.00 foot & 0.50 foot & 0.25 foot & 0.10 foot \\
\hline 7 & A 8340 & 3.54 & 0.10 & 0.10 & 0.06 & 100.0 & 99.7 & 99.1 & 76.5 \\
\hline 8 & A4649 & 4.00 & 0.12 & 0.10 & 0.09 & 99.8 & 99.2 & 96.6 & 54.9 \\
\hline 10 & A7650 & 1.57 & 0.12 & 0.10 & 0.07 & 99.9 & 99.4 & 97.0 & 50.5 \\
\hline 11 & A5817 & 3.38 & 0.09 & 0.10 & 0.06 & 100.0 & 99.7 & 98.8 & 75.1 \\
\hline 12 & A0767 & 2.82 & 0.12 & 0.10 & 0.08 & 99.9 & 99.5 & 97.2 & 50.8 \\
\hline 13 & A4757/L0568 & 3.87 & 0.13 & 0.10 & 0.09 & 99.8 & 99.2 & 96.4 & 50.4 \\
\hline
\end{tabular}



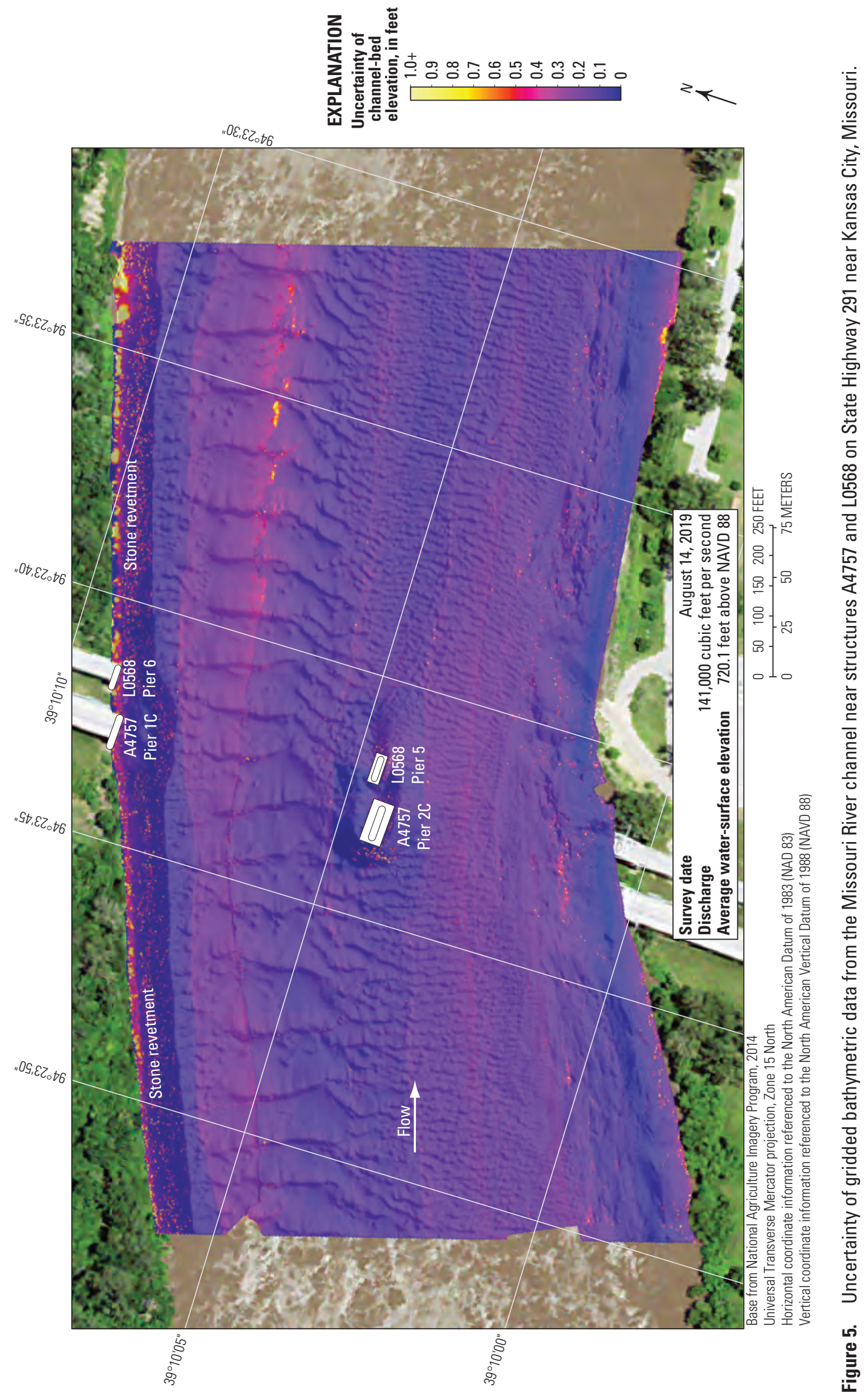


\section{Results of Bathymetric and Velocimetric Surveys}

The site-specific results for each bridge are discussed in the following sections, starting with the upstream-most bridge and progressing downstream. The site-specific results are followed by a discussion of general findings that are not specific to a particular site. The range of bed elevations described as "the channel-bed elevations" for each survey was based on statistical analysis of the gridded raster surface of the bathymetry data at each site and covers the 5 th to 95 th percentile range of the data. Because the surveys generally were limited to the active channel from bank to bank excluding overbank areas, this percentile range generally covered the channel bed but excluded the banks and localized high or low spots, such as spur dikes or scour holes near piers. All elevation data were referenced to the North American Vertical Datum of 1988 (NAVD 88).

For consistency with earlier studies, dune sizes are described in general terms for each of the bridge sites using the categories set by Huizinga (2012) for the discussion of bathymetry during the 2011 flood. In this report, small dunes and ripples are those that are less than $5 \mathrm{ft}$ high from crest to trough, medium dunes are those that are 5 to $10 \mathrm{ft} \mathrm{high,} \mathrm{large}$ dunes are those that are 10 to $15 \mathrm{ft}$ high, and very large dunes are those that are $15 \mathrm{ft}$ or more in height.

All the bridge sites in this study were previously surveyed (Huizinga, 2010, 2012, 2016), and bathymetry data from earlier surveys at all eight crossings are included with metadata in Huizinga (2020b). A map showing the difference in channel-bed elevation for the area common to the comparison surveys is included for each site, and data from previous surveys are included in the cross-section plot for that bridge. The difference maps were created using the Geomorphic Change Detection (GCD) add-in tool for ArcGIS available through the Riverscapes Consortium (2020). GCD computes elevation difference and volumetric change in storage between two gridded raster surfaces (each as a digital elevation model, or "DEM" of the surface) derived from repeat topographic surveys. The GCD program provides a suite of tools to associate the uncertainties for points in the various surveys (using the uncertainty values associated with each point, or an average uncertainty of the survey when point-specific uncertainty data were not available [2010 survey data]) and propagates those uncertainties through the DEM of difference (DoD) map. The GCD program also provides a way to segregate the best estimates of change using threshold masks. A threshold mask of 95-percent confidence was used for comparisons in the current study, and summary statistics (maximum, minimum, and average) of the DoD maps were determined. Sediment volumes for cut (scour) and fill (deposition) between the 2019 survey and previous surveys in 2010, 2011 and 2015 also were determined. The surveys are broadly compared based on their timing and the streamflow at the time of the survey. Additionally, shaded triangulated irregular network (TIN) images of the channel and side of pier were prepared for each surveyed pier. These visualizations are shown in appendix 1 , figures 1.1 to 1.10 .

Although the configuration of the channel bed and the underlying sediment transport conditions at a site are associated with an instantaneous streamflow in the discussions that follow, a given bathymetric surface actually is a reflection of more than those instantaneous transport conditions. A wide variety of factors affect the channel-bed configuration of a reach for a specific streamflow, including magnitude of flow velocities and velocity distribution, the number, size, and timing of previous flood rises, whether or not the stage currently is rising or falling, and other local hydraulic conditions (Gilbert and Murphy, 1914; Simons and Richardson, 1966). Furthermore, the channel-bed configuration at a site is affected by upstream and local sediment conditions (size and spatial distribution) and contributions, as well as water temperature and other seasonal variations (Simon, $\mathrm{Li}$ and Associates, 1985). Because of the myriad number and interactions between factors affecting sediment transport conditions and the resultant bed configuration, it was assumed that the configuration and size of bed forms observed during the current (2019) surveys in the Kansas City area depended on more than the instantaneous streamflow at a given site. Although it is beyond the scope of the current (2019) study to examine all the antecedent conditions that created the observed channelbed configuration, the comparisons with previous surveys under different streamflow conditions nevertheless contributes to understanding the many complexities of sediment transport.

As in recent previous studies (Huizinga, 2012, 2013, 2014, 2015, 2016, 2017a, 2020a, e), when discussing the vertically averaged velocity values obtained during the surveys in the sections that follow, neighboring vectors having random variations in direction and magnitude were taken as an indication of nonuniform flow in the section resulting from shear and wake vortices. Conversely, neighboring vectors having gradual and systematic variations were taken as an indication of uniform flow in the section. The Missouri River is highly turbulent even in the absence of structures that generate strong shear or wakes, but in the interest of conciseness, nonuniform flow is loosely described as "turbulent" in the following sections. 


\section{Structure A1800 on Interstate 635}

Structure A1800 (site 6; table 1) on Interstate 635 crosses the Missouri River at river mile (RM) 374.1, on the northwestern side of Kansas City (fig. 1). The site was surveyed on August 13, 2019, and the average water-surface elevation of the river in the survey area, determined by the RTK GNSS tide solution, was $731.9 \mathrm{ft}$ (table 5; fig. 6). Streamflow on the Missouri River was about 112,000 $\mathrm{ft}^{3} / \mathrm{s}$ during the survey (table 5).

The survey area was about 1,640 ft long and averaged about $755 \mathrm{ft}$ wide, extending across the active channel from bank to bank (fig. 6). The upstream end of the survey area was about $770 \mathrm{ft}$ upstream from the centerline of structure A1800 (fig. 6). The channel-bed elevations ranged from about 698 to $719 \mathrm{ft}$ for most of the surveyed area (5th to 95th percentile range of the bathymetric data; table 5; fig. 7). A thalweg along the outside of the channel bend on the right (south) bank was about $15 \mathrm{ft}$ deeper than the channel bed on the inside of the bend on the left (north) bank (fig. 6). Several medium to large dune features were detected in the middle of the channel along the left side of the thalweg, and the left (north) side and thalweg on the right (south) side were covered with numerous small dunes and ripples (fig. 6). As in previous surveys (Huizinga, 2010, 2012, 2016), a rock outcrop and stone revetment were present on the right (south) bank throughout the reach (fig. 6).

The scour hole near main channel pier 3 had a minimum channel-bed elevation of about $692 \mathrm{ft}$ (table 6), about $18 \mathrm{ft}$ below the average channel bed immediately upstream from the pier (the value of the "depth of scour hole from upstream channel bed" in table 6; fig. 6), and about $10 \mathrm{ft}$ below the elevation of the bottom of the pier seal course of $702.28 \mathrm{ft}$ (fig. 8; table 6). Information from bridge plans indicates that pier 3 is founded on shafts drilled $20 \mathrm{ft}$ into bedrock, and about $40 \mathrm{ft}$ of bed material are between the bottom of the scour hole and bedrock at the upstream face of pier 3 (fig. 8; table 6).

The difference between the survey on August 13, 2019, and the previous nonflood survey on June 2, 2015 (fig. 9), indicates about 73 percent of the joint area of interest had detectable change, which means about 27 percent of the differences in the joint area of interest are equivocal and within the uncertainty. Bed variation seemed about equal between scour and deposition in the middle part of the channel from 2015 to 2019 in the DoD map; however, in the thalweg downstream from the bridge and along the left (north) bank throughout

Table 5. Bridge and survey information, and selected channel-bed elevations from surveys on the Missouri River near Kansas City, Missouri, August 13-14, 2019.

[Dates are shown as month/day/year. All elevations are referenced to the North American Vertical Datum of 1988. MoDOT, Missouri Department of Transportation; ADCP, acoustic Doppler current profiler; IS, Interstate highway; US, U.S. highway; MO, State highway]

\begin{tabular}{|c|c|c|c|c|c|c|c|c|c|c|}
\hline \multirow[t]{2}{*}{$\begin{array}{c}\text { Site } \\
\text { number } \\
\text { (fig. 1) }\end{array}$} & \multirow[t]{2}{*}{$\begin{array}{c}\text { MoDOT } \\
\text { structure } \\
\text { number }\end{array}$} & \multirow[t]{2}{*}{$\begin{array}{c}\text { Survey } \\
\text { date }\end{array}$} & \multirow[t]{2}{*}{ Route } & \multirow[t]{2}{*}{$\begin{array}{l}\text { River } \\
\text { mile }^{\mathrm{a}}\end{array}$} & \multirow[t]{2}{*}{$\begin{array}{c}\text { Streamflow } \\
\text { from ADCP } \\
\text { measurements, } \\
\text { in cubic feet per } \\
\text { second }\end{array}$} & \multirow{2}{*}{$\begin{array}{c}\text { Average } \\
\text { water-surface } \\
\text { elevation } \\
\text { near the } \\
\text { bridge, } \\
\text { in feet }\end{array}$} & \multirow[t]{2}{*}{$\begin{array}{l}\text { Average } \\
\text { channel- } \\
\text { bed } \\
\text { elevation,c } \\
\text { in feet }\end{array}$} & \multicolumn{2}{|c|}{$\begin{array}{c}\text { Approximate } \\
\text { elevation of the } \\
\text { indicated percentile of } \\
\text { the bathymetric data, } \\
\text { in feet }\end{array}$} & \multirow{2}{*}{$\begin{array}{l}\text { Approximate } \\
\text { minimum } \\
\text { channel } \\
\text { elevation, } \\
\text { in feet }\end{array}$} \\
\hline & & & & & & & & $\begin{array}{c}\text { 5th } \\
\text { percentile }\end{array}$ & $\begin{array}{c}\text { 95th } \\
\text { percentile }\end{array}$ & \\
\hline 8 & A4649 & 08/13/19 & US 169 & 366.2 & 126,000 & 729.0 & 703.5 & 689.1 & 719.2 & 676 \\
\hline 9 & A4060 & 08/13/19 & MO 9 & 365.5 & 126,000 & 728.2 & 700.1 & 689.9 & 715.1 & 678 \\
\hline 10 & A7650 & 08/14/19 & IS 35 & 364.7 & 142,000 & 728.2 & 697.6 & 689.7 & 714.1 & 671 \\
\hline 11 & A5817 & $08 / 14 / 19$ & MO 269 & 362.3 & 142,000 & 726.5 & 700.7 & 690.6 & 711.6 & 683 \\
\hline
\end{tabular}

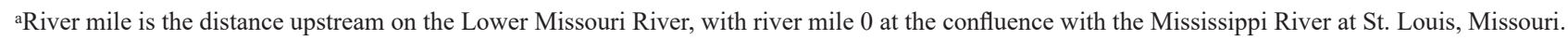
(fig. 1), at river mile 195.2 of the Upper Mississippi River.

bThe average streamflow obtained while making the various velocity transects. The reported value is the streamflow computed using Global Navigation Satellite System (GNSS) essential fix data string as the reference, as described in the "Surveying Methods" section of the text.

cThe statistical average of the surveyed channel-bed elevations.

dThe minimum channel-bed elevation, not necessarily in any scour holes near the bridge.

eThe minimum channel-bed elevation is in a scour hole near a substructural element at this site. 


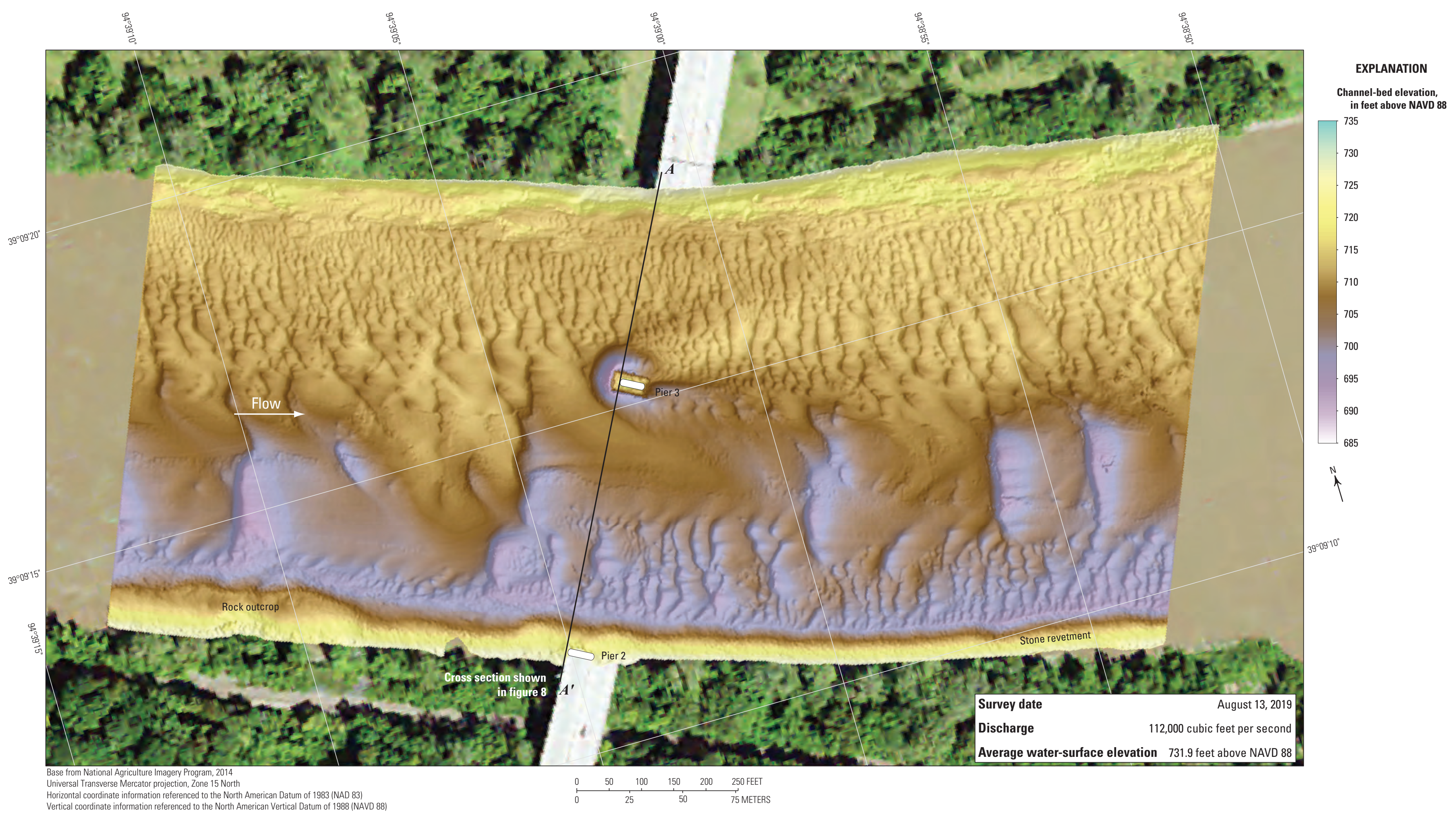

Figure 6. Bathymetric survey of the Missouri River channel near structure A1800 on Interstate 635 in Kansas City, Missouri, on August 13, 2019 


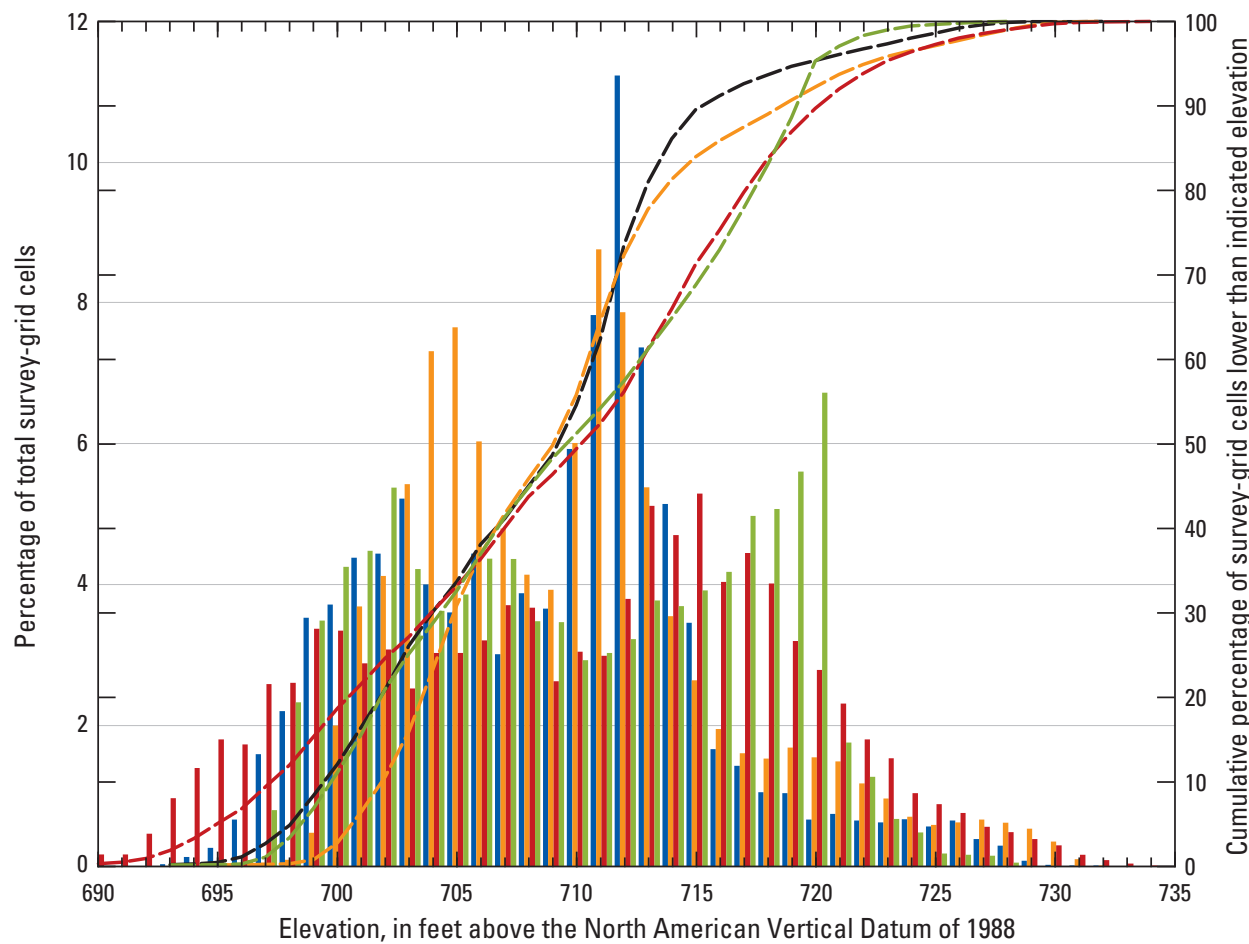

\section{EXPLANATION}

$\left[\mathrm{ft}^{3} / \mathrm{s}\right.$, cubic foot per second $]$

\section{Frequency distribution}

- 2019 survey data; $112,000 \mathrm{ft}^{3} / \mathrm{s}$

2015 survey data; $73,000 \mathrm{ft}^{3} / \mathrm{s}$

- 2011 survey data; $213,000 \mathrm{ft}^{3} / \mathrm{s}$

2010 survey data; $103,000 \mathrm{ft}^{3} / \mathrm{s}$

Cumulative percentage

- 2019 survey data; $112,000 \mathrm{ft}^{3} / \mathrm{s}$

_- 2015 survey data; $73,000 \mathrm{ft}^{3} / \mathrm{s}$

- 2011 survey data; $213,000 \mathrm{ft}^{3} / \mathrm{s}$

_ 2010 survey data; $103,000 \mathrm{ft}^{3} / \mathrm{s}$

Figure 7. Frequency distribution of bed elevations for bathymetric survey-grid cells in 1-foot elevation bins on the Missouri River near structure A1800 on Interstate 635 in Kansas City, Missouri, on August 13, 2019, compared to previous surveys in 2010, 2011, and 2015 (Huizinga, 2010, 2012, 2016, respectively). 


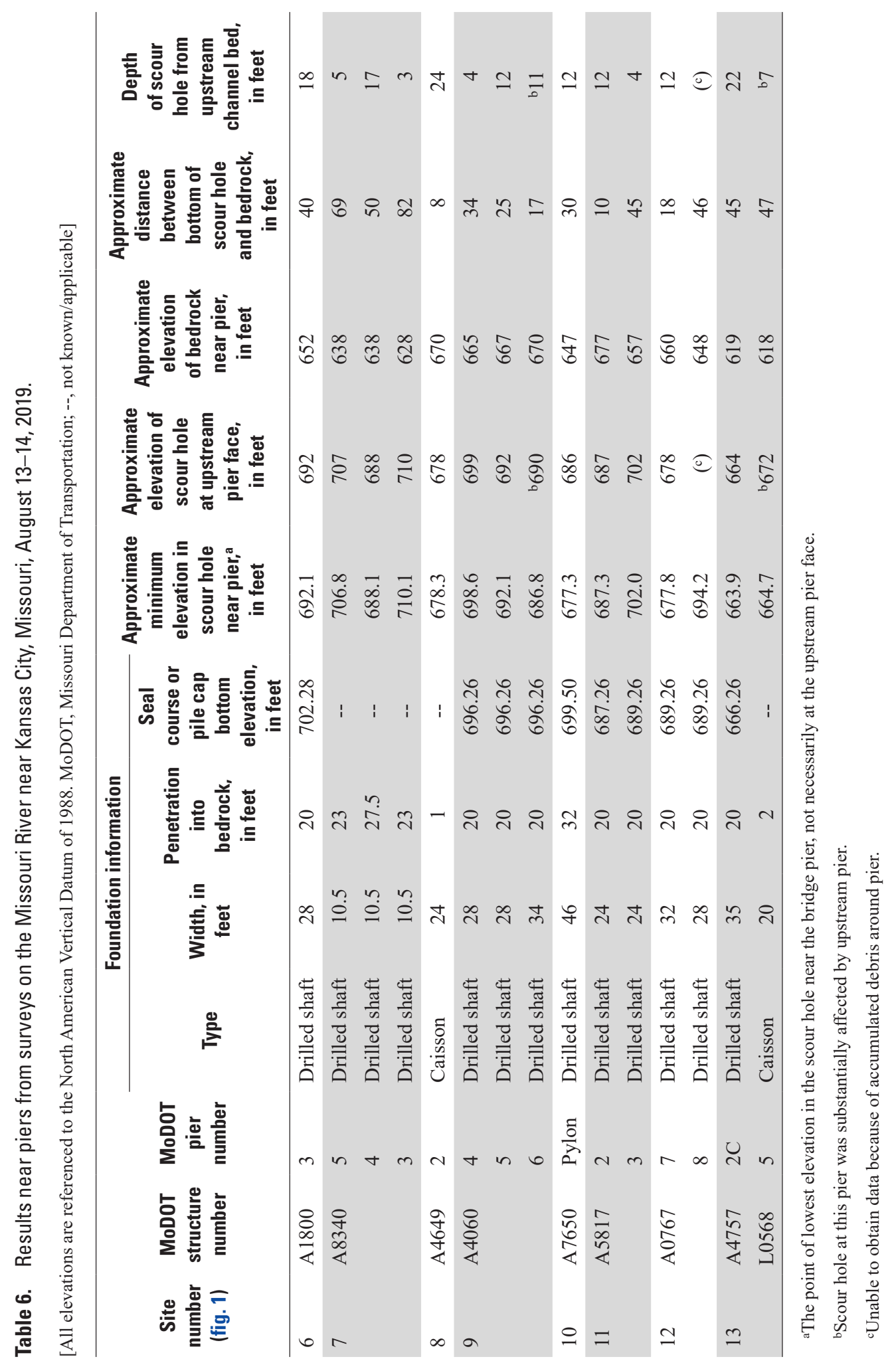



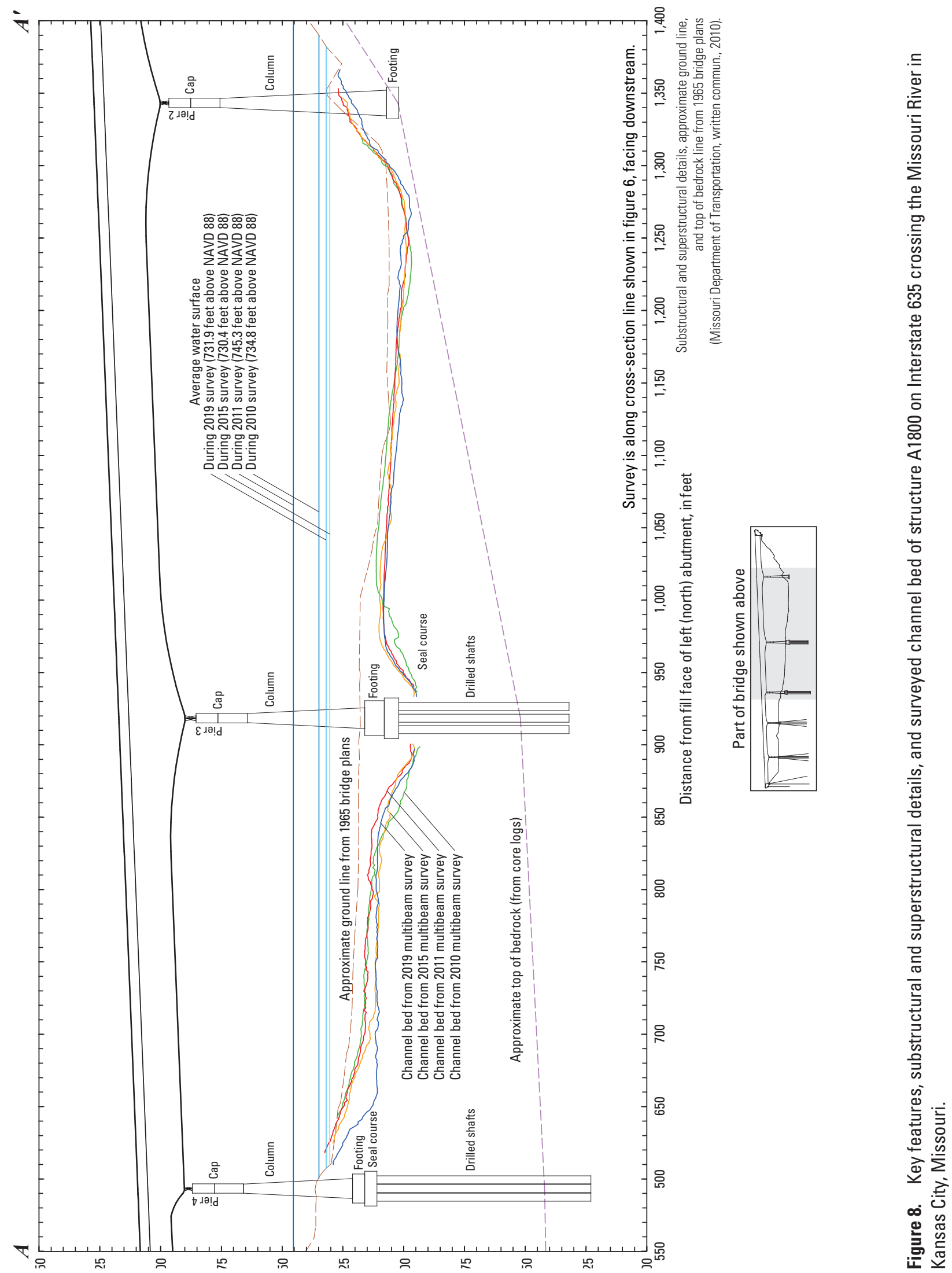


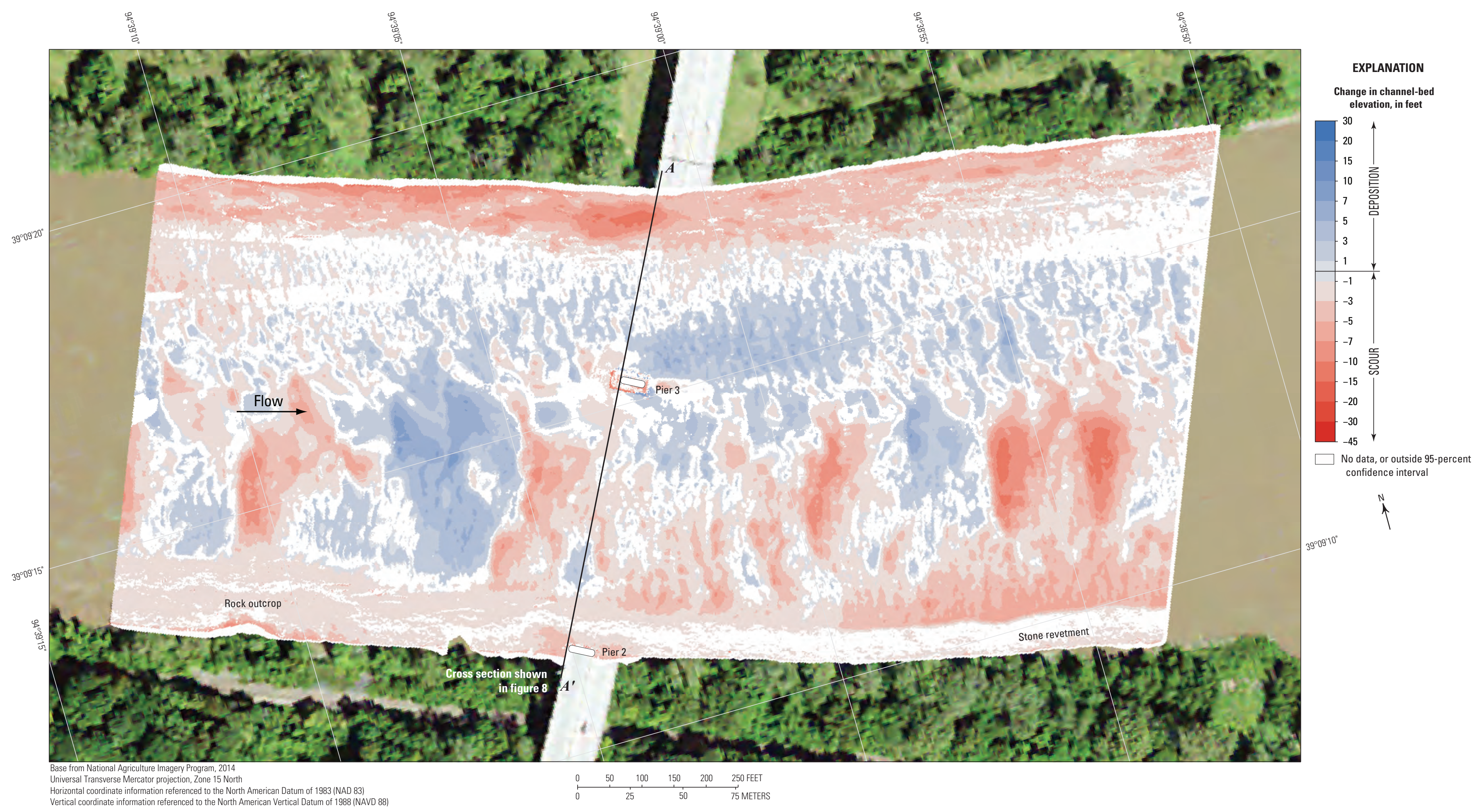

Figure 9. Difference between surfaces created from bathymetric surveys of the Missouri River channel near structure A1800 on Interstate 635 in Kansas City, Missouri, on August 13, 2019 , and June 2, 2015 
要

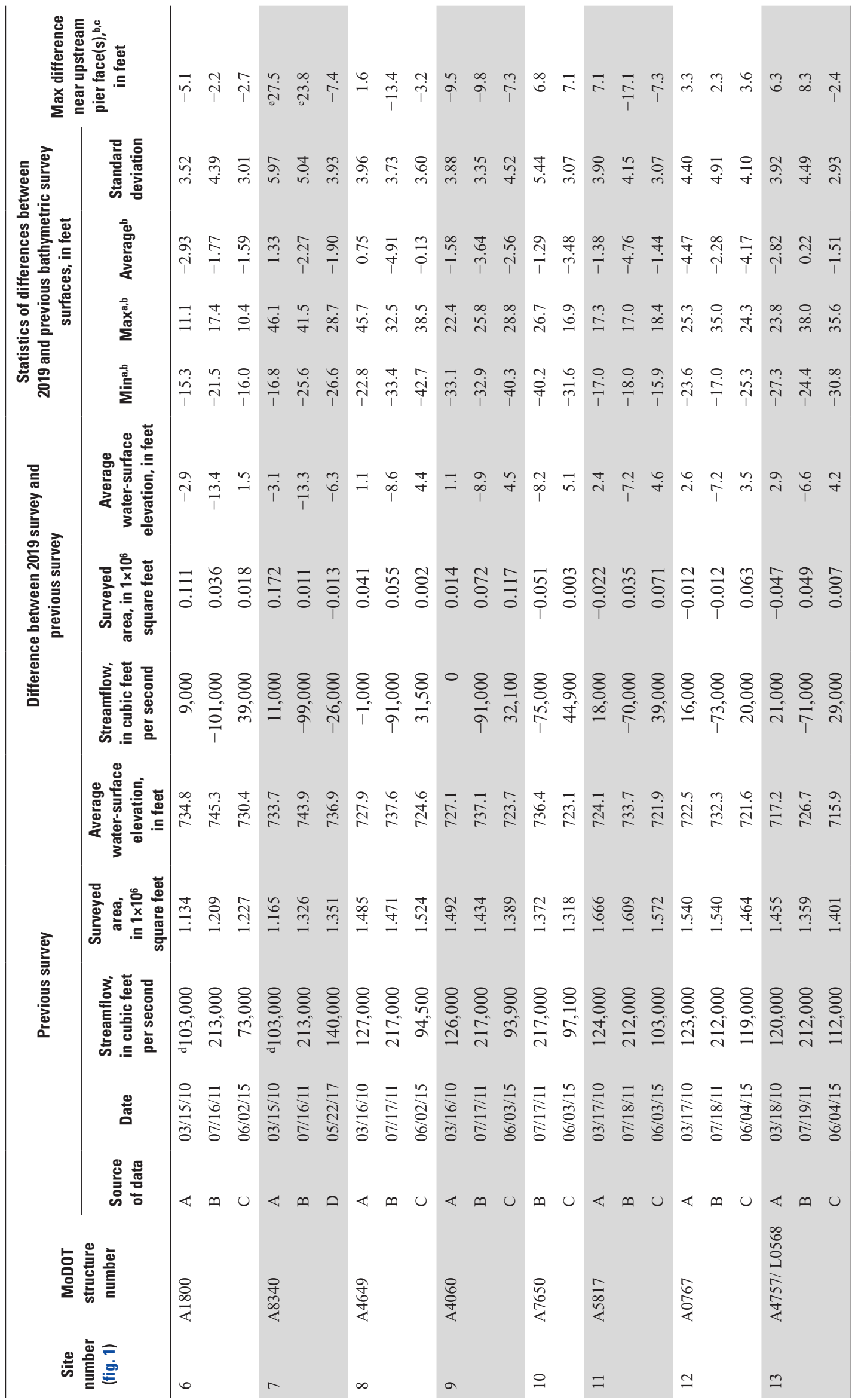

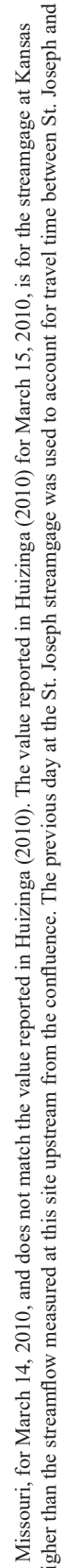

을

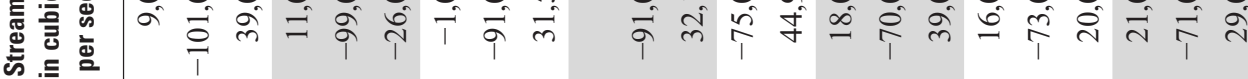

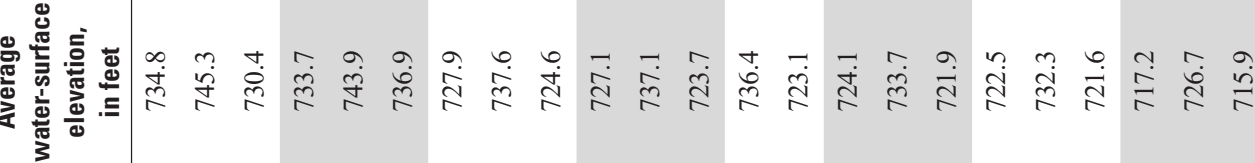

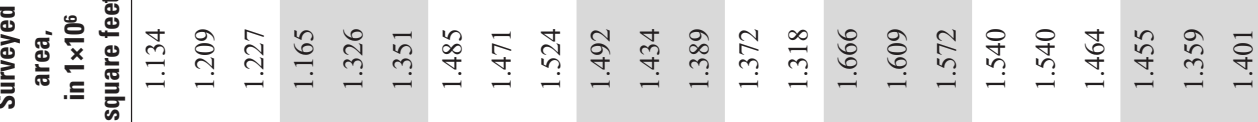

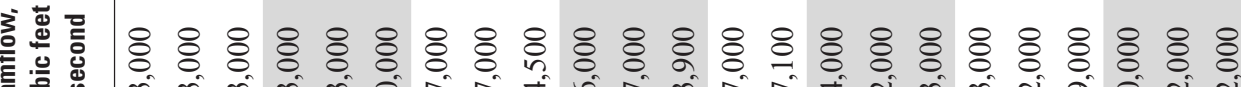
产言 创

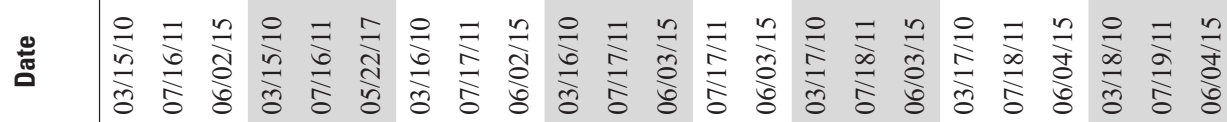


the reach, scour is dominant (fig. 9). The average difference between the bathymetric surfaces (the statistical mean value of the gridded raster surface [fig. 9] created from the difference between the 2019 and 2015 gridded raster bathymetric surfaces) was $-1.59 \mathrm{ft}$ (table 7), indicating moderate channel degradation between the 2015 and 2019 surveys. The net volume of cut in the reach from 2015 to 2019 was about 72,900 cubic yards $\left(\mathrm{yd}^{3}\right)$, and the net volume of fill was about $20,900 \mathrm{yd}^{3}$, resulting in a net loss of about $52,000 \mathrm{yd}^{3}$ of sediment between 2015 and 2019. The cross sections from the two surveys along the upstream face of the bridge are not substantially different from one another for most of the cross section, except near the left bank where the 2019 section is substantially lower than all the previous sections (fig. 8). The frequency distribution of bed elevations in 2019 also was similar to 2015 but with a higher percentage of cells at lower channel-bed elevations (fig. 7). The scour hole near pier 3 was of a very similar shape in 2019 and 2015 (fig. 8), as evidenced by the overall area of "no data" or minimal change around the pier (fig. 9). The rock outcrop on the right (south) bank showed signs of minor scour upstream from the bridge (fig. 9). Although rock ultimately is an erodible material, its rate of erosion is substantially slower than that of sand and silt (Arneson and others, 2012). The stone revetment on the downstream right (south) bank showed no signs of substantial change (fig. 9). Substantial deposition or scour apparent at the faces of the pier footing results from minor horizontal positional variances between the surveys (see "Uncertainty Estimation" section).

The difference between the survey on August 13, 2019, and the previous flood survey on July 16, 2011 (fig. 10), indicates about 85 percent of the joint area of interest had detectable change, which means about 15 percent of the differences in the joint area of interest are equivocal and within the uncertainty. Substantial bed variation is apparent from 2011 to 2019 in the DoD map, particularly near the thalweg where large dune features were present in the 2011 survey (Huizinga, 2012). Whereas scour of as much as $15 \mathrm{ft}$ seems dominant on the left (north) side of the channel in the DoD map, deposition of as much as $10 \mathrm{ft}$ seems dominant in the thalweg (fig. 10). The average difference between the bathymetric surfaces was $-1.77 \mathrm{ft}$ (table 7), indicating moderate net channel degradation between the 2011 and 2019 surveys. The net volume of cut in the reach from 2011 to 2019 was about $110,500 \mathrm{yd}^{3}$, and the net volume of fill was about $43,500 \mathrm{yd}^{3}$, resulting in a net loss of about $67,000 \mathrm{yd}^{3}$ of sediment between 2011 and 2019. As with the 2015 survey, the cross sections from the two surveys along the upstream face of the bridge are not substantially different from one another for most of the cross section, except near the left bank where the 2019 section is substantially lower than all the previous sections (fig. 8). The frequency distribution of bed elevations in 2019 also was similar in shape but narrower to 2011, and had a higher percentage of cells at the middle channel-bed elevations (fig. 7). As with the 2015 survey, the scour hole near pier 3 was of a very similar shape in 2019 and 2011 (fig. 8), again as evidenced by the overall area of "no data" or minimal change around the pier in the DoD map (fig. 10). The rock outcrop on the right (south) bank showed signs of more substantial scour upstream from the bridge, and the stone revetment on the downstream right (south) bank showed signs of minor scour (fig. 10). As with the previous DoD map, substantial deposition or scour apparent at the faces of the pier footing results from minor horizontal positional variances between the surveys (see "Uncertainty Estimation" section).

The difference between the survey on August 13, 2019, and the earliest nonflood survey on March 15, 2010 (fig. 11), indicates about 87 percent of the joint area of interest had detectable change, which means about 13 percent of the differences in the joint area of interest are equivocal and within the uncertainty. Scour is dominant throughout most of the reach between 2010 and 2019 in the DoD map, except near some dune features present in the middle of the channel in 2010 and near pier 3 (Huizinga, 2010; fig. 11). The average difference between the bathymetric surfaces was $-2.93 \mathrm{ft}$ (table 7), indicating substantial channel degradation between the 2010 and 2019 surveys. The net volume of cut in the reach from 2010 to 2019 was about $122,700 \mathrm{yd}^{3}$, and the net volume of fill was about $20,500 \mathrm{yd}^{3}$, resulting in a net loss of about $102,200 \mathrm{yd}^{3}$ of sediment between 2010 and 2019. Whereas the cross sections from the two surveys along the upstream face of the bridge are not substantially different from one another for most of the cross section, as with all the surveys the 2019 section is substantially lower than all the previous sections near the left bank (fig. 8). The frequency distribution of bed elevations in 2019 was very similar to 2010 for elevations below about $708 \mathrm{ft}$; however, above the 2019 distribution has a higher percentage of cells at a lower channel-bed elevation than 2010 (fig. 7). The scour hole near pier 3 was deeper and wider in 2010 than in 2019 (fig. 8), as evidenced by large horseshoe-shaped area of deposition around the pier in the DoD map (fig. 11). The rock outcrop on the right (south) bank showed signs of moderate scour upstream from the bridge, and the stone revetment on the downstream right (south) bank showed signs of minor scour (fig. 11). As with previous DoD maps, substantial deposition or scour apparent at the faces of the pier footing results from minor horizontal positional variances between the surveys (see "Uncertainty Estimation" section).

The vertically averaged velocity vectors indicate mostly uniform flow throughout the reach (fig. 12). A maximum velocity of about 11 feet per second ( $\mathrm{ft} / \mathrm{s}$ ) was present in the thalweg immediately upstream from the bridge, and a minimum of $3 \mathrm{ft} / \mathrm{s}$ was present along the inside of the bend on the left (north) bank (fig. 12). The wake vortices downstream from pier 3 were not pronounced and seemed to be no greater than the general nonuniformity of flow observed in the channel (fig. 12). Minor turbulence was present in all the sections (fig. 12). 


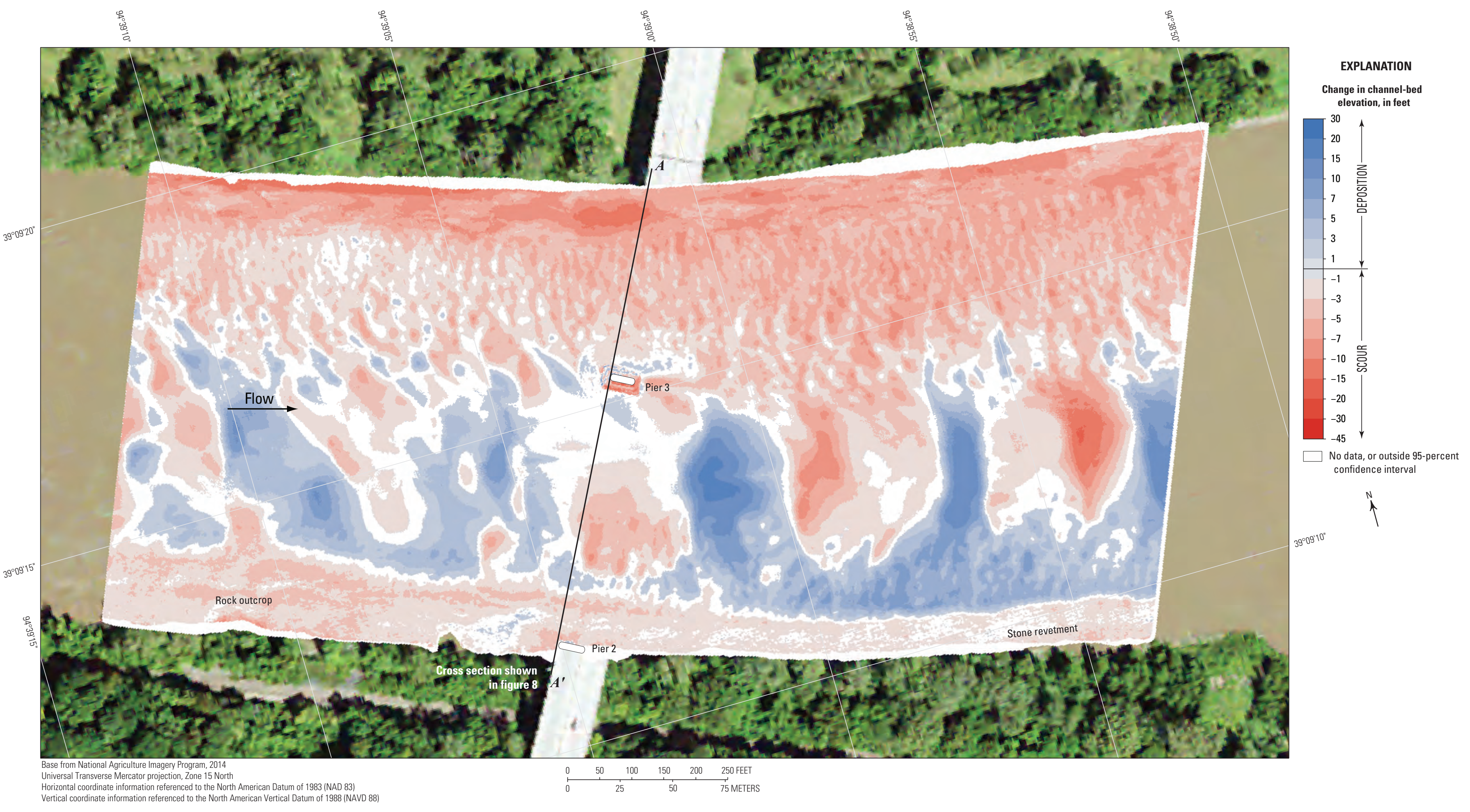

Figure 10. Difference between surfaces created from bathymetric surveys of the Missouri River channel near structure A1800 on Interstate 635 in Kansas City, Missouri, on August 13, 2019 , and July 16, 2011. 


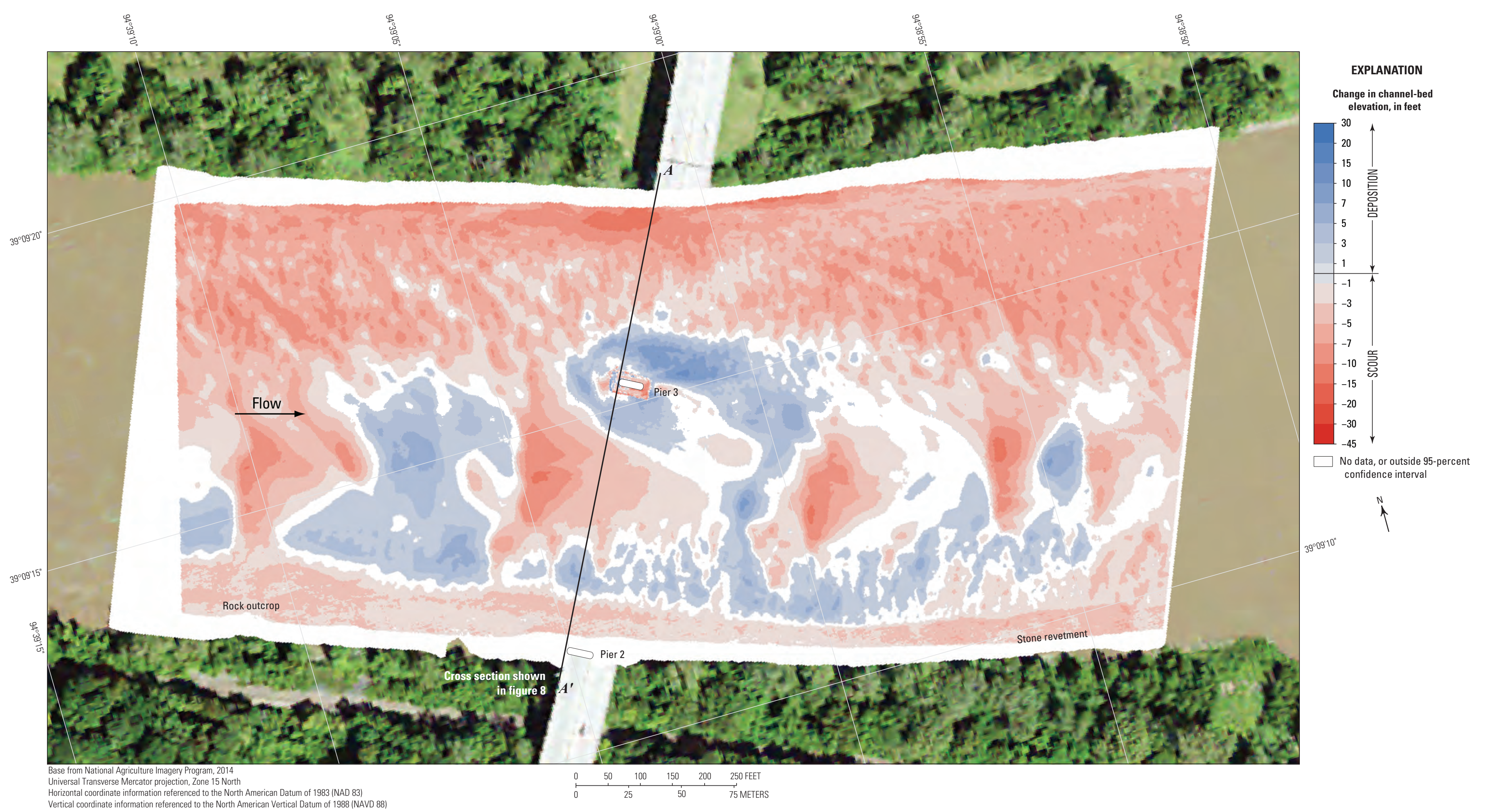

Figure 11. Difference between surfaces created from bathymetric surveys of the Missouri River channel near structure A1800 on Interstate 635 in Kansas City, Missouri, on August 13, 2019 , and March 15, 2010. 


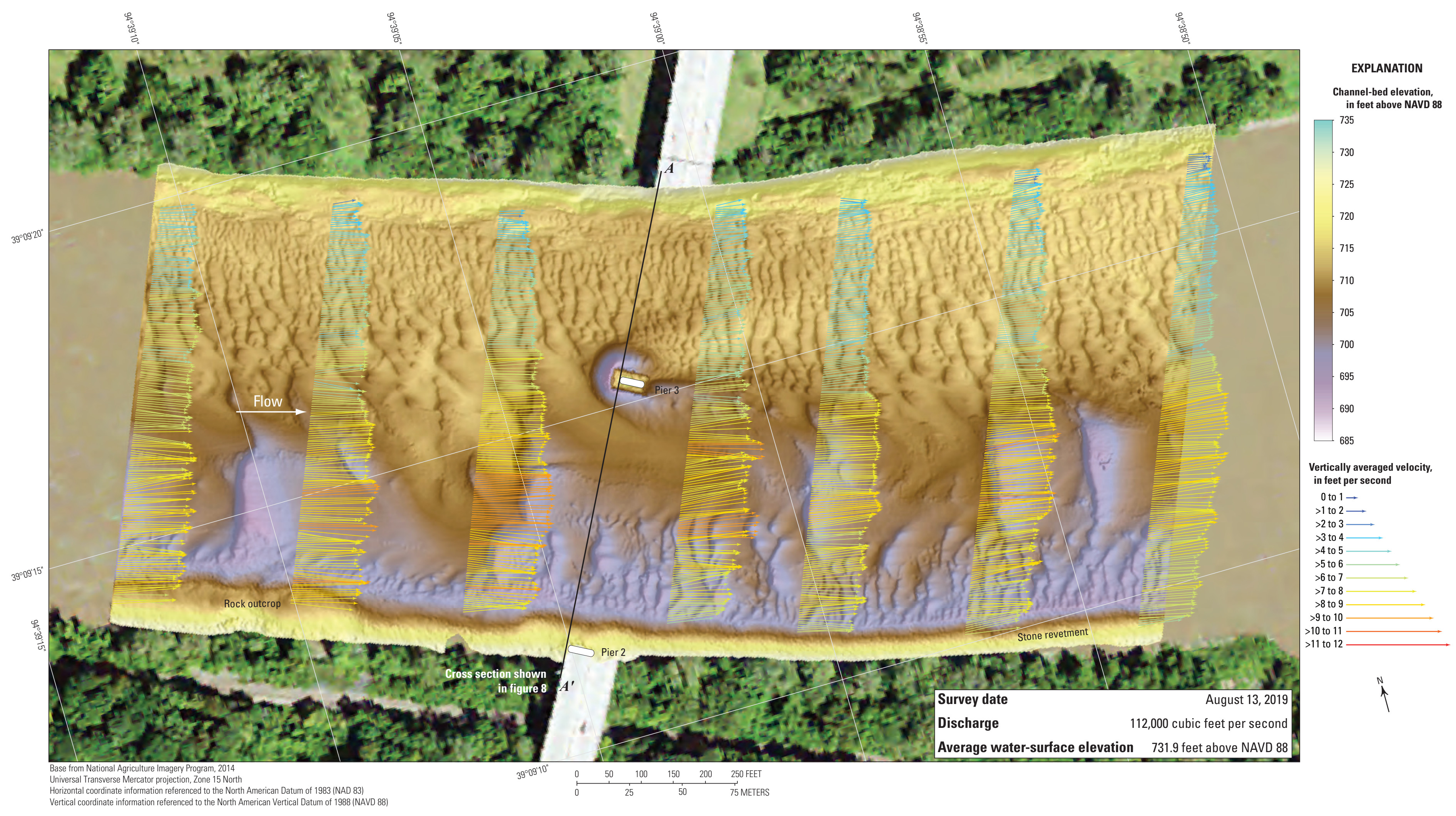

Figure 12. Bathymetry and vertically averaged velocities of the Missouri River channel near structure A1800 on Interstate 635 in Kansas City, Missouri, on August 13, 2019. 


\section{Structure A8340 on U.S. Highway 69}

Structure A8340 (site 7; table 1) on U.S. Highway 69 crosses the Missouri River at RM 372.6, on the northwestern side of Kansas City (fig. 1). The site was surveyed on August 13, 2019, and the average water-surface elevation of the river in the survey area, determined by the RTK GNSS tide solution, was $730.6 \mathrm{ft}$ (table 5; fig. 13). Streamflow on the Missouri River was about 114,000 $\mathrm{ft}^{3} / \mathrm{s}$ during the survey (table 5).

The survey area was about $1,550 \mathrm{ft}$ long and averaged about $875 \mathrm{ft}$ wide, extending across the active channel from bank to bank (fig. 13). The upstream end of the survey area was about $680 \mathrm{ft}$ upstream from the centerline of structure A8340 (fig. 13). The channel-bed elevations ranged from about 698 to $717 \mathrm{ft}$ for most of the surveyed area (5th to 95th percentile range of the bathymetric data; table 5; fig. 14), except near the central main channel bent 4 of structure A8340 (fig. 13). There was a defined thalweg along the toe of the right (south) bank, which was about $12 \mathrm{ft}$ deeper than the channel bed in the middle of the channel (fig. 13). A series of medium dunes was present in the middle of the channel, and numerous other small dunes and ripples were present throughout the rest of the channel (fig. 13). As in previous surveys (Huizinga, 2010, 2012, 2020a), stone revetment was present on the right (south) bank throughout the reach, and two spur dikes were present on the left (north) bank (fig. 13). Partial remnants of the pier from old structure A0450 were evident to the right and downstream from bent 4 of structure A8340 (fig. 13).

A local scour hole near bent 4 had an approximate minimum channel-bed elevation of about $688 \mathrm{ft}$ (table 6), the minimum elevation for the surveyed area (table 5), and about $17 \mathrm{ft}$ below the average channel bed immediately upstream from the bent (table 6; fig. 13). A local scour hole near bent 5 had a minimum elevation of $707 \mathrm{ft}$, about $5 \mathrm{ft}$ below the average channel bed immediately upstream from the pier (fig. 13; table 6). Bent 3 is surrounded by the rock revetment on the right (south) bank, but a very small depression of about $3 \mathrm{ft}$ was present in the revetment near the upstream face of the upstream column (fig. 13; table 6). Information from bridge plans indicates that all the main channel bents of structure A8340 are shafts drilled about 23 to $28 \mathrm{ft}$ into bedrock and have about $50 \mathrm{ft}$ of bed material between the bottom of the scour hole and bedrock at bent 4 (fig. 15; table 6); bents 5 and 3 have about 69 and $82 \mathrm{ft}$ of bed material between the bottom of the scour hole and bedrock, respectively (fig. 15; table 6).

The difference between the survey on August 13, 2019, and the previous nonflood survey on May 22, 2017 (fig. 16), indicates about 93 percent of the joint area of interest had detectable change, which means only 7 percent of the differences in the joint area of interest are equivocal and within the uncertainty. Bed variation appears to be predominately scour from 2017 to 2019 in the DoD map, except downstream from the spur dikes and in the troughs of dunes present in the 2017 survey (Huizinga, 2020a; fig. 16). The average difference between the bathymetric surfaces was $-1.90 \mathrm{ft}$ (table 7), indicating moderate channel degradation between the 2017 and 2019 surveys. The net volume of cut in the reach from 2017 to 2019 was about $119,600 \mathrm{yd}^{3}$, and the net volume of fill was about $33,900 \mathrm{yd}^{3}$, resulting in a net loss of about $85,700 \mathrm{yd}^{3}$ of sediment between 2017 and 2019. The cross sections from the two surveys along the upstream face of the bridge indicate a nearly uniform lowering of about $5 \mathrm{ft}$ for most of the cross section (fig. 15). The frequency distribution of bed elevations in 2019 was similar in shape to 2017 but with a higher percentage of cells at lower channel-bed elevations (fig. 14). The scour holes near main channel bents 4 and 5 were of a very similar shape in 2019 and 2017 (fig. 15), as evidenced by the overall area of similar change around the bents in the DoD map (fig. 16). The stone revetment on the right (south) bank also showed signs of nearly uniform minor scour (fig. 16).

The difference between the survey on August 13, 2019, and the previous flood survey on July 16, 2011 (fig. 17), indicates about 88 percent of the joint area of interest had detectable change, which means about 12 percent of the differences in the joint area of interest are equivocal and within the uncertainty. Substantial bed variation is again apparent from 2011 to 2019 in the DoD map, with scour predominant throughout the reach except for substantial deposition at the former location of the old bridge piers near bent 4 and in the downstream thalweg and the troughs of dunes present in the 2011 survey (Huizinga, 2012). Whereas scour of greater than $10 \mathrm{ft}$ appears dominant on the left (north) side of the channel in the DoD map, deposition of as much as $10 \mathrm{ft}$ occurred in the thalweg, and deposition of more than $20 \mathrm{ft}$ occurred downstream from the downstream spur dike (fig. 17). The average difference between the bathymetric surfaces was $-2.27 \mathrm{ft}$ (table 7), indicating substantial net channel degradation between the 2011 and 2019 surveys. The net volume of cut in the reach from 2011 to 2019 was about 137,700 $\mathrm{yd}^{3}$, and the net volume of fill was about $45,600 \mathrm{yd}^{3}$, resulting in a net loss of about 92,100 $\mathrm{yd}^{3}$ of sediment between 2011 and 2019. As with the 2017 survey, the cross sections from the two surveys along the upstream face of the bridge indicate a nearly uniform lowering of 5 to $10 \mathrm{ft}$ for most of the cross section except the location of the former pier (fig. 15). The frequency distribution of bed elevations in 2019 also was similar in shape but slightly narrower to 2011, with a higher percentage of cells at the middle channel-bed elevations (fig. 14). The differences in the frequency distribution of bed elevations in 2017 and 2019 from 2011 (fig. 14) likely are a direct result of the new bridge bents, which are designed to be more hydrodynamic and less scour-inducing than the old bridge piers. The stone revetment on the right (south) bank also showed signs of nearly uniform minor scour in the DoD map (fig. 17). 


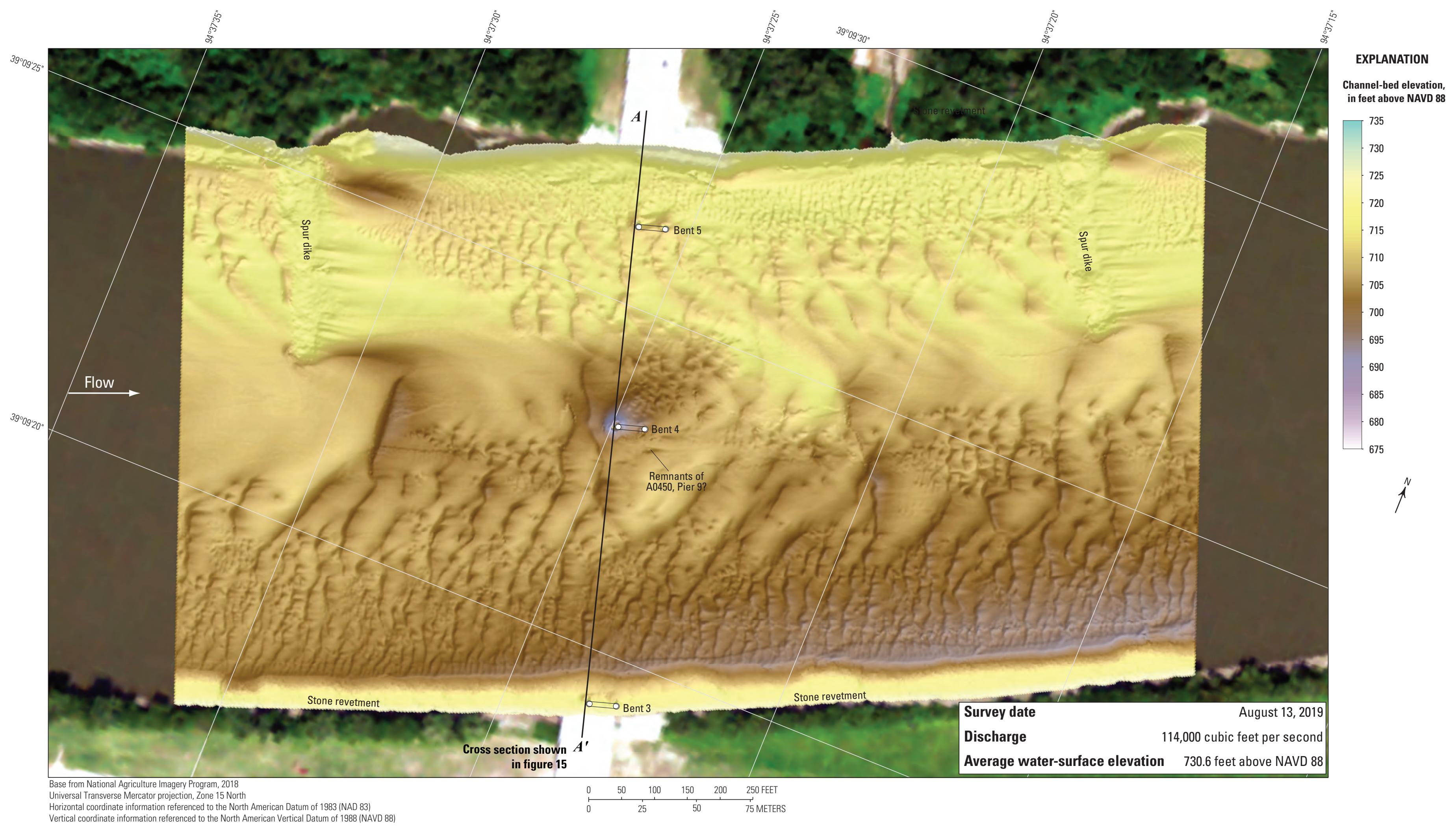

Figure 13. Bathymetric survey of the Missouri River channel near structure A8340 on U.S. Highway 69 in Kansas City, Missouri, on August 13, 2019 


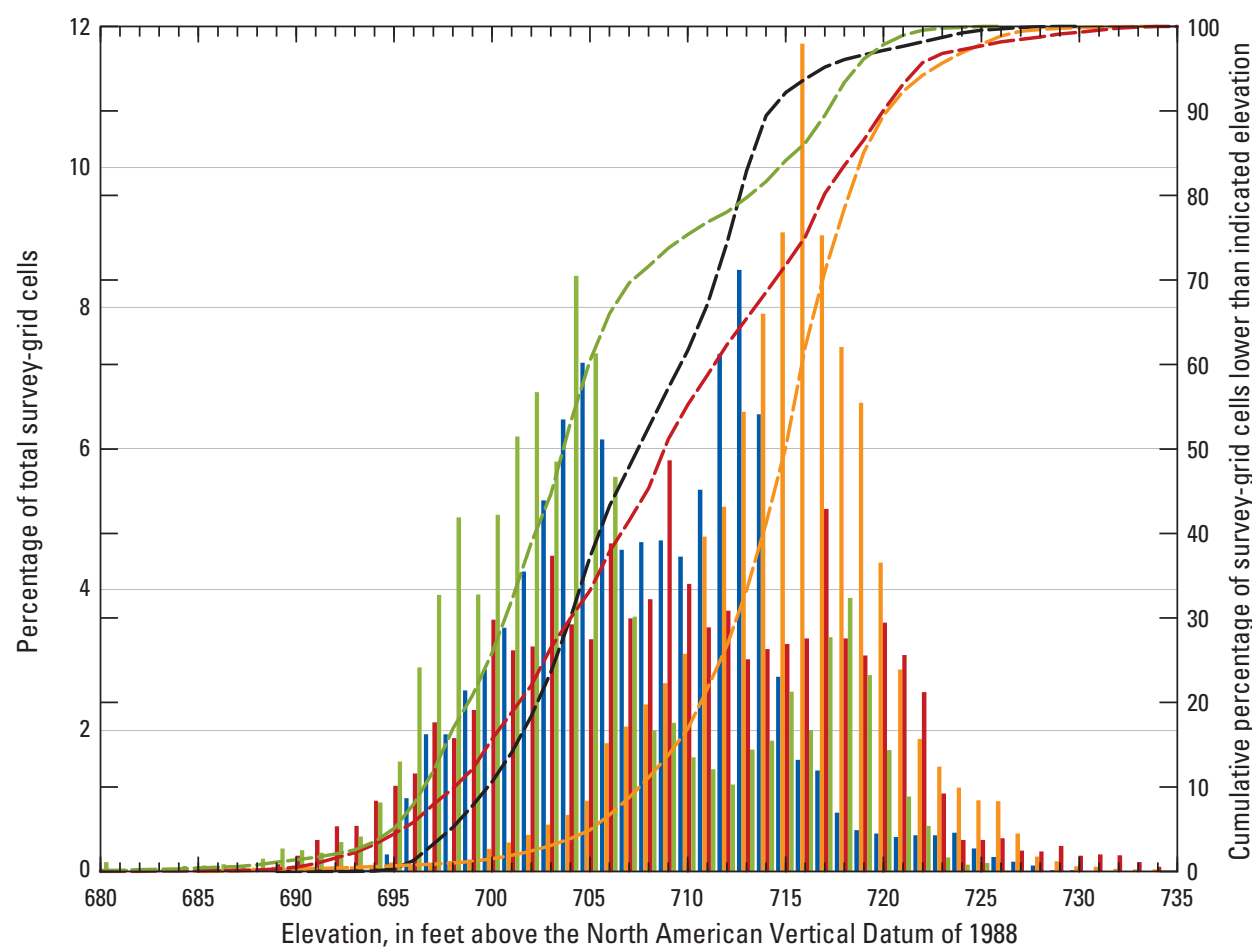

\section{EXPLANATION}

$\left[\mathrm{ft}^{3} / \mathrm{s}\right.$, cubic foot per second]

\section{Frequency distribution}

2019 survey data; $142,000 \mathrm{ft}^{3} / \mathrm{s}$

2017 survey data; $140,000 \mathrm{ft}^{3} / \mathrm{s}$

2011 survey data; $213,000 \mathrm{ft}^{3} / \mathrm{s}$

2010 survey data; $103,000 \mathrm{ft}^{3} / \mathrm{s}$

Cumulative percentage

- 2019 survey data; $114,000 \mathrm{ft}^{3} / \mathrm{s}$

- 2017 survey data; $140,000 \mathrm{ft}^{3} / \mathrm{s}$

- 2011 survey data; $213,000 \mathrm{ft}^{3} / \mathrm{s}$

_ 2010 survey data; $103,000 \mathrm{ft}^{3} / \mathrm{s}$

Figure 14. Frequency distribution of bed elevations for bathymetric survey-grid cells in 1-foot elevation bins on the Missouri River near structure A8340 on U.S. Highway 69 in Kansas City, Missouri, on August 13, 2019, compared to previous surveys in 2010, 2011, and 2017 (Huizinga, 2010, 2012, 2020a, respectively). 


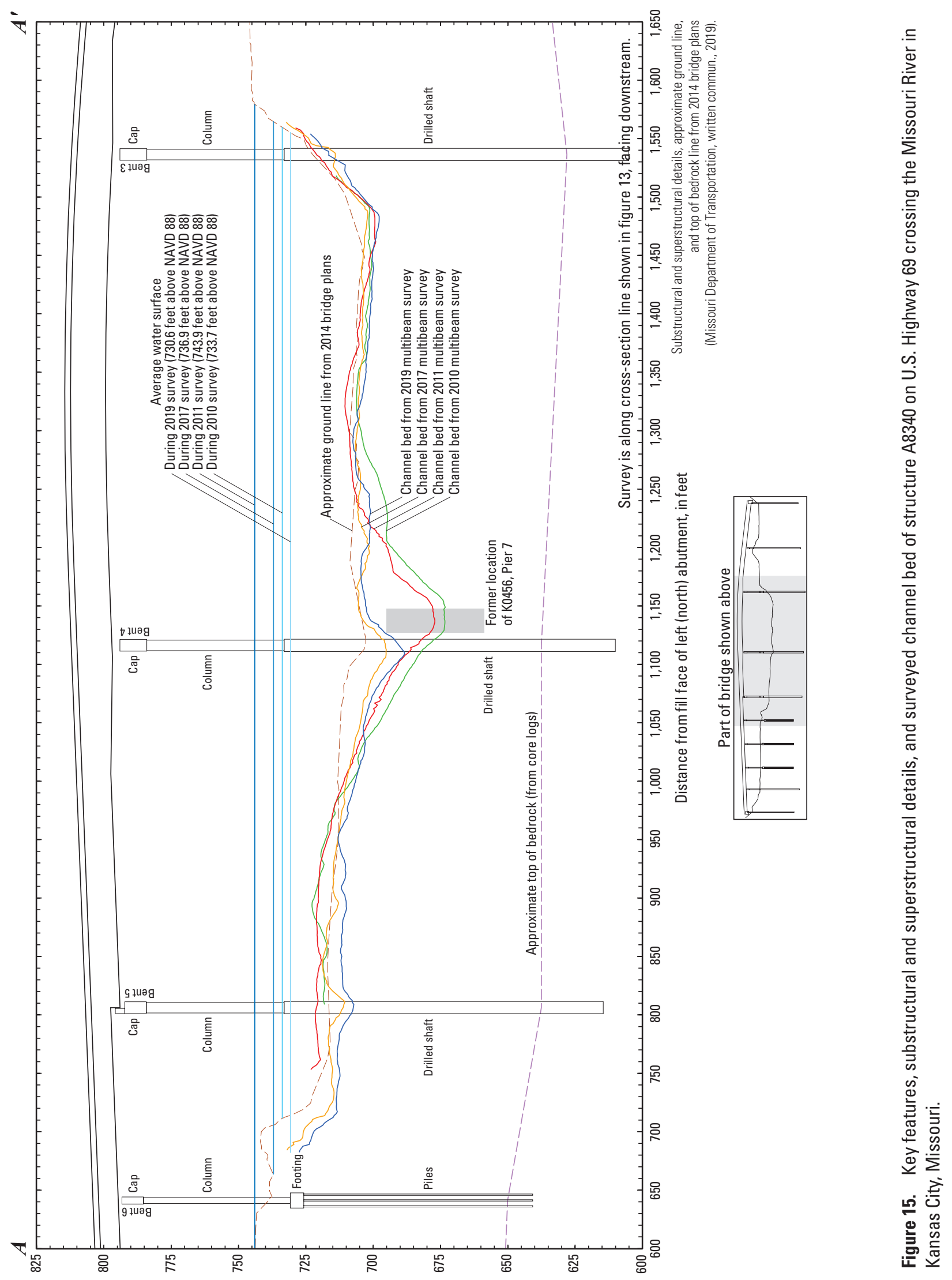




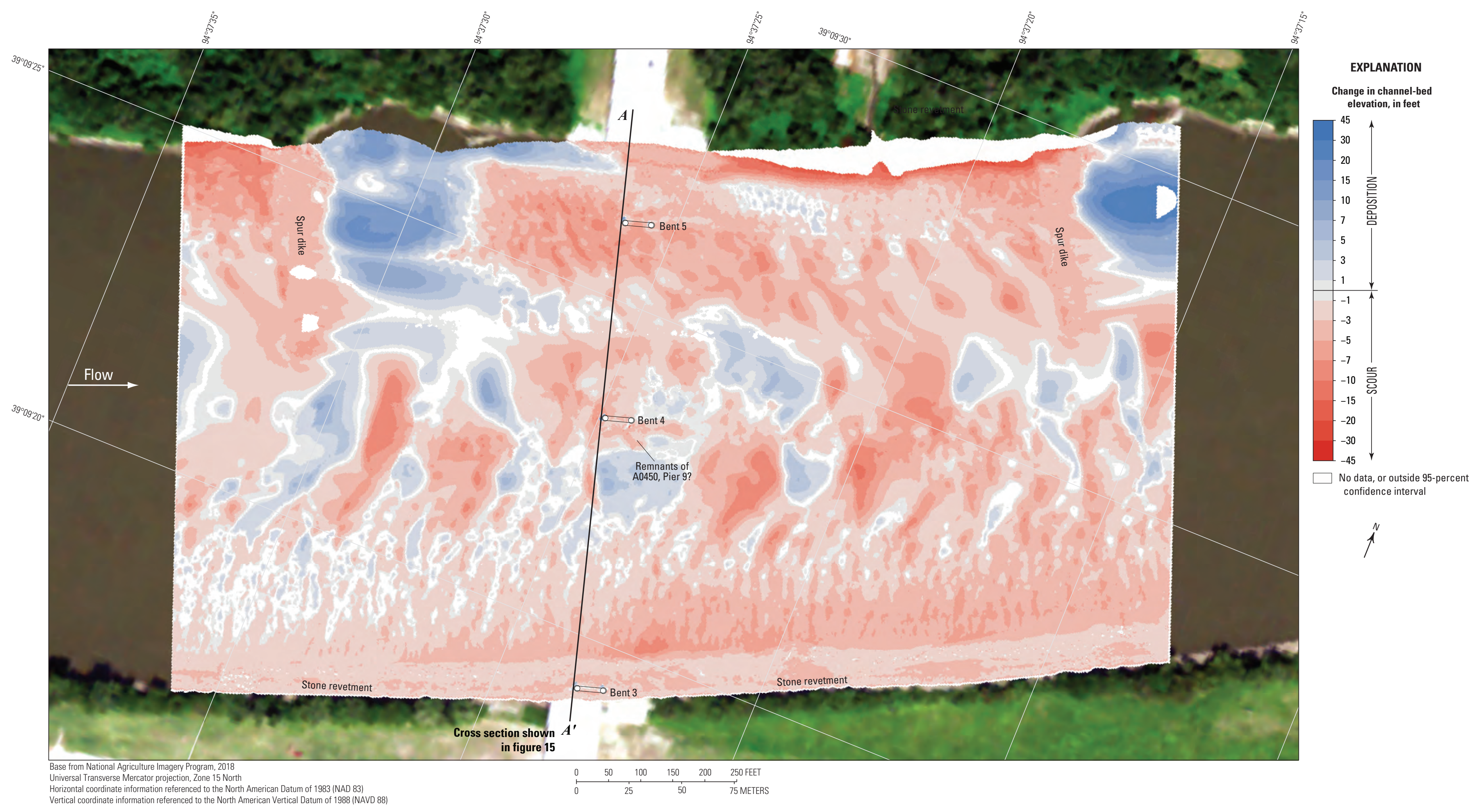

Figure 16. Difference between surfaces created from bathymetric surveys of the Missouri River channel near structure A8340 on U.S. Highway 69 in Kansas City, Missouri, on August 13, 2019, and May 22, 2017. 


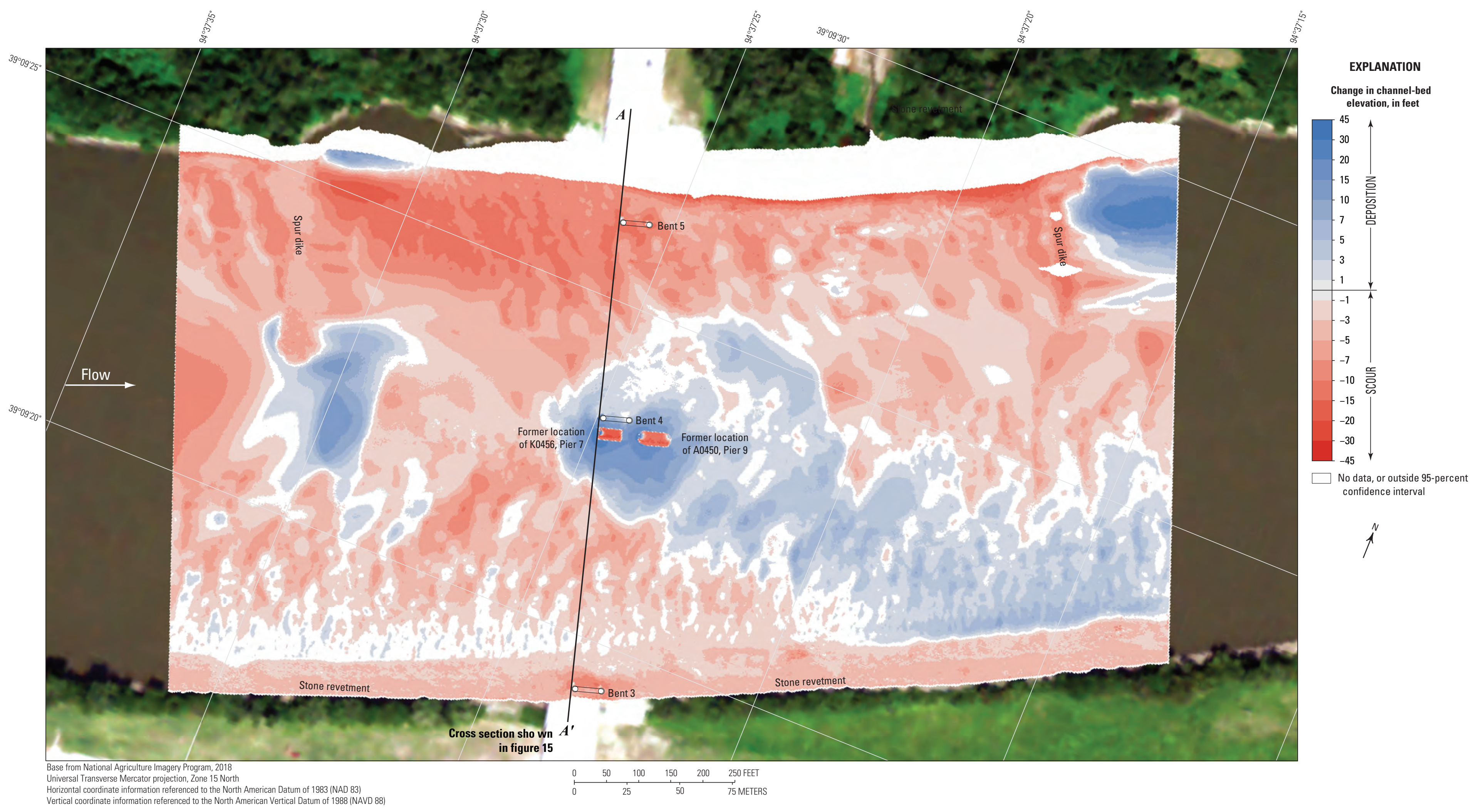

Figure 17. Difference between surfaces created from bathymetric surveys of the Missouri River channel near structure A8340 on U.S. Highway 69 in Kansas City, Missouri, on August 13, 2019 , and July 16, 2011. 
The difference between the survey on August 13, 2019, and the earliest nonflood survey on March 15, 2010 (fig. 18), indicates about 84 percent of the joint area of interest had detectable change, which means about 16 percent of the differences in the joint area of interest are equivocal and within the uncertainty. Bed variation appeared about equal between scour and deposition from 2010 to 2019 in the DoD map, with scour predominant along the left (north) side of the channel and on the right (south) bank, and deposition predominant in the middle of the channel, particularly at the former location of the old bridge piers near bent 4 , in the thalweg along the right (south) bank, and in the troughs of dunes present in the 2010 survey (Huizinga, 2010; fig. 18). The average difference between the bathymetric surfaces was $+1.33 \mathrm{ft}$ (table 7 ), indicating moderate channel aggradation between the 2010 and 2019 surveys. The net volume of cut in the reach from 2010 to 2019 was about $57,100 \mathrm{yd}^{3}$, and the net volume of fill was about $100,900 \mathrm{yd}^{3}$, resulting in a net gain of about $43,800 \mathrm{yd}^{3}$ of sediment between 2010 and 2019. The cross sections from the two surveys along the upstream face of the bridge are substantially different from one another for most of the left side and become more similar to one another about midway between bents 3 and 4 (fig. 15). The frequency distribution of bed elevations in 2010 was somewhat unique compared to the other surveys, but the 2019 distribution was similar to 2010, except with a lower percentage of cells at a lower channelbed elevation than 2010 (fig. 14). As noted in the previous paragraph, the differences in the frequency distribution of bed elevations in 2017 and 2019 from 2011 and 2010 (fig. 14) likely are a direct result of the new bridge bents, which are designed to be more hydrodynamic and less scour-inducing than the old bridge piers. As with all the DoD maps for this site, stone revetment on the right (south) bank also showed signs of nearly uniform minor scour (fig. 18).

The vertically averaged velocity vectors indicate mostly uniform flow throughout the reach (fig. 19). A maximum velocity of about $10 \mathrm{ft} / \mathrm{s}$ was present in the upstream middle of the channel, and a minimum velocity of about $1 \mathrm{ft} / \mathrm{s}$ was present with flow reversal downstream from the various spur dikes in the reach (fig. 19). Minimal effect on the velocity was observed downstream from bent 4 (fig. 19), indicating the new pier design is appropriately hydrodynamic. Minor turbulence was present in all the sections (fig. 19). 


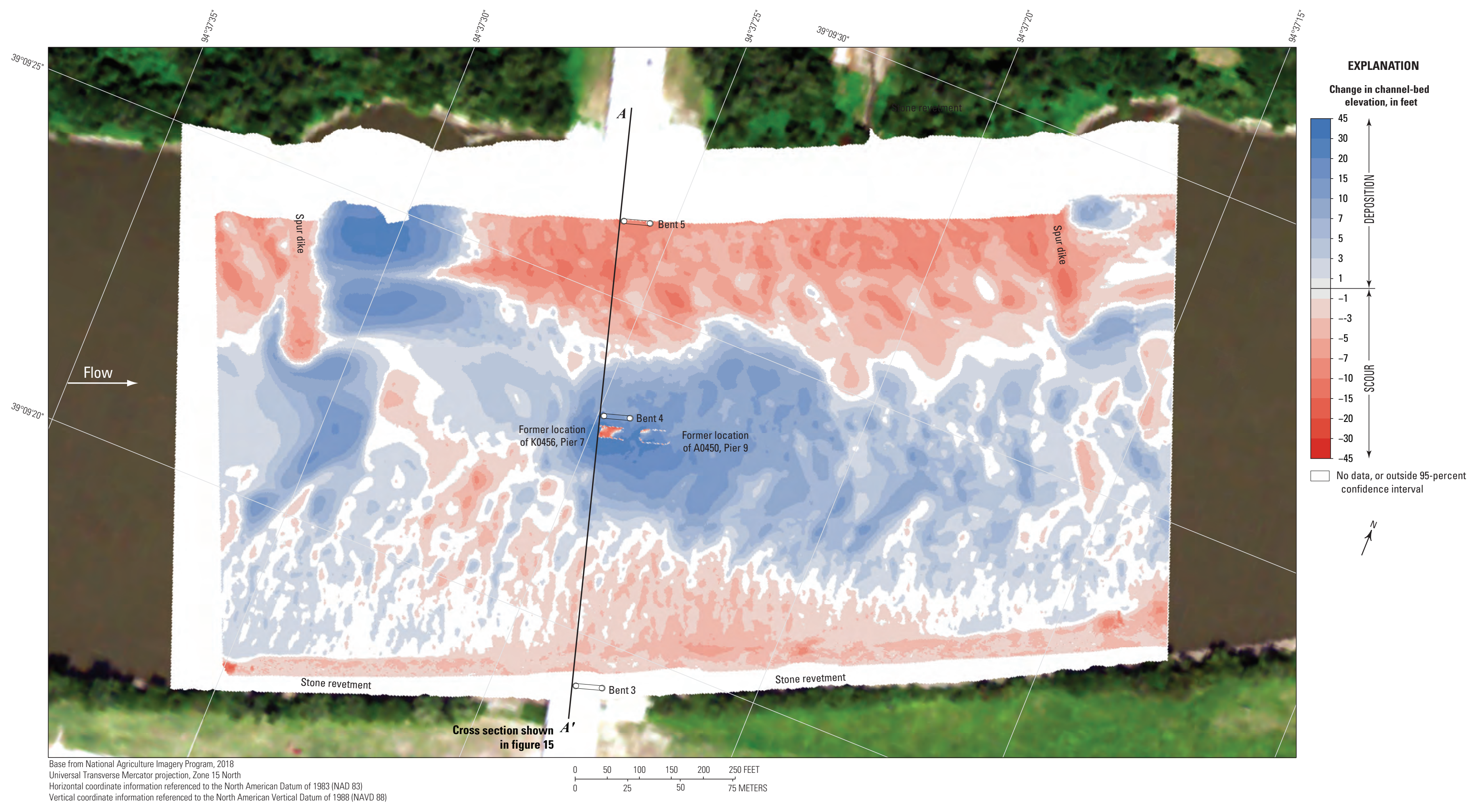

Figure 18. Difference between surfaces created from bathymetric surveys of the Missouri River channel near structure A8340 on U.S. Highway 69 in Kansas City, Missouri, on August 13, 2019 , and March 15, 2010. 


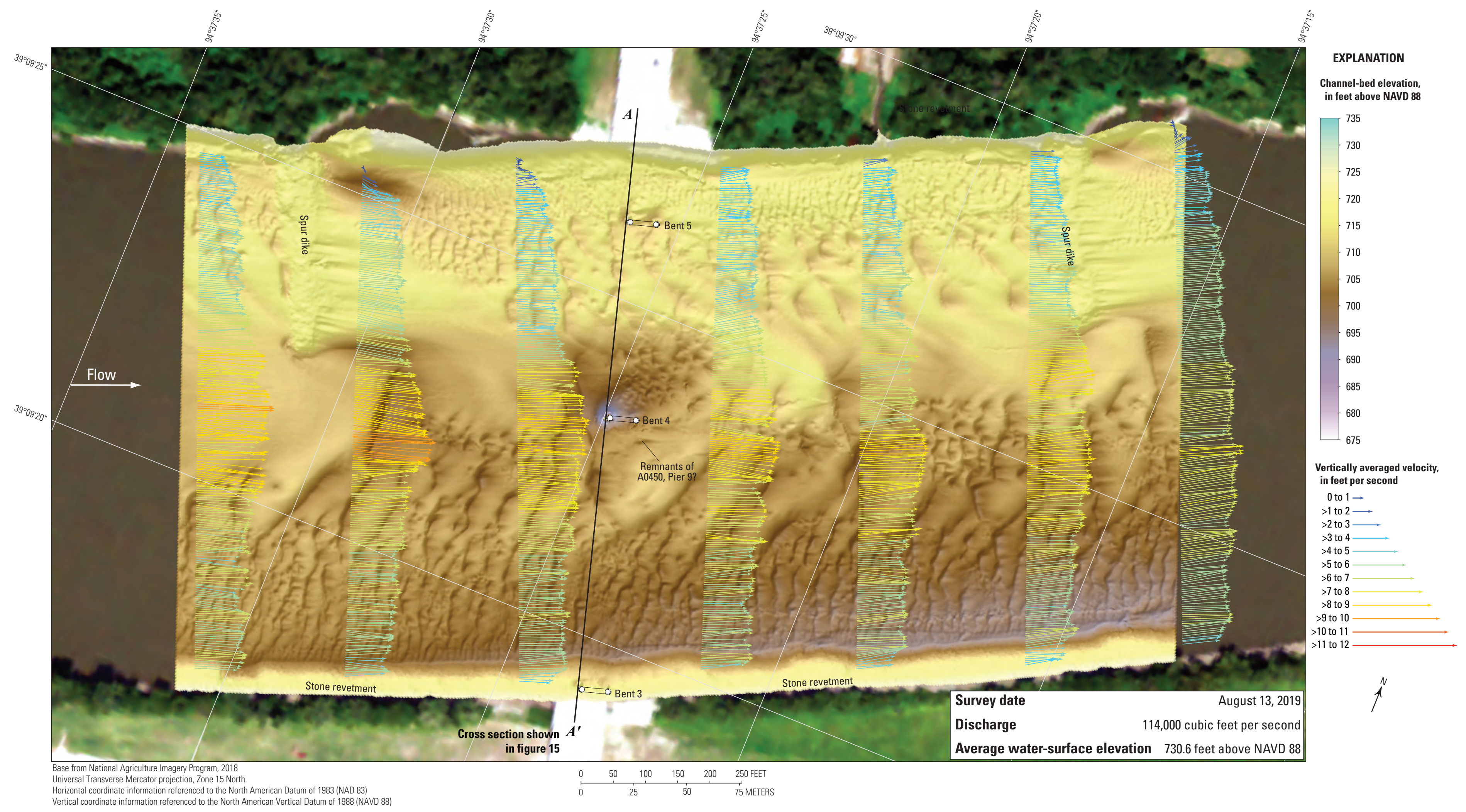

Figure 19. Bathymetry and vertically averaged velocities of the Missouri River channel near structure A8340 on U.S. Highway 69 in Kansas City, Missouri, on August 13, 2019. 


\section{Structure A4649 on U.S. Highway 169}

Structure A4649 (site 8; table 1) on U.S. Highway 169 crosses the Missouri River at RM 366.2, immediately north of downtown Kansas City, Mo. (fig. 1). The site was surveyed on August 13, 2019, and the average water-surface elevation of the river in the survey area, determined by the RTK GNSS tide solution, was $729.0 \mathrm{ft}$ (table 5; fig. 20). Streamflow on the Missouri River was about $126,000 \mathrm{ft}^{3} / \mathrm{s}$ during the survey (table 5).

The survey area was about 1,660 ft long and averaged about $910 \mathrm{ft}$ wide, extending from bank to bank in the main channel (fig. 20). The upstream end of the survey area was about $720 \mathrm{ft}$ upstream from the centerline of structure A4649 at pier 2 (fig. 20). The channel-bed elevations ranged from about 689 to $719 \mathrm{ft}$ for most of the surveyed area (5th to 95th percentile range of the bathymetric data; table 5; fig. 21), except near pier 2 of structure A4649, the various railroad bridge piers, and the concrete nose upstream from the railroad bridge turntable pier (fig. 20). A deep thalweg on the right (south) bank on the upstream end of the surveyed area was about $20 \mathrm{ft}$ deeper than the channel bed in the middle of the channel (fig. 20). The thalweg became shallower and shifted to the left at the bridges and downstream (fig. 20). As in previous surveys at this site (Huizinga, 2010, 2012, 2016), remnants of piers from an old bridge were evident downstream from the existing railroad bridge (fig. 20). Numerous medium and small dunes and ripples were detected throughout the channel, with slightly larger features in the channel thalweg upstream from structure A4649 and on the left side of the channel downstream from the railroad bridge (fig. 20). Also as in previous surveys, stone revetment was present on the right (south) bank throughout the reach (fig. 20).

A scour hole near main channel pier 2 (fig. 20) had a minimum channel-bed elevation of about $678 \mathrm{ft}$ (table 6), about $24 \mathrm{ft}$ below the average channel bed immediately upstream from the pier (table 6). As in previous surveys at this site (Huizinga, 2010, 2012, 2016), the scour hole was more extensive around the right (south) side of the pier, with a submerged remnant of a structure near the left (north) downstream side of the pier (figs. 20 and 1.3A), presumably a nose for the railroad bridge downstream similar to the concrete nose upstream from the railroad bridge turntable pier. Also, as in the previous surveys at this site, the remnants of the old railroad bridge piers were clearly defined, as were the piles of particulate rock debris around them. The remnant bridge pier downstream from the existing railroad bridge turntable pier had a maximum elevation of about $710 \mathrm{ft}$, which is about $13 \mathrm{ft}$ above the channel bed immediately upstream from it and about $19 \mathrm{ft}$ below the water surface at the time of the 2019 survey. Avoidance of this pier remnant might be difficult for large vessels in flow conditions lower than those on the day of the survey. The overall minimum channel-bed elevation was $676 \mathrm{ft}$ (table 5) and was observed upstream from the left railroad bridge pier downstream from pier 2 of structure A4649. Information from bridge plans indicate that the main channel pier 2 of structure A4649 is a caisson on bedrock, and has about $8 \mathrm{ft}$ of bed material between the bottom of the scour hole and the bottom of the caisson (fig. 22; table 6).

The difference between the survey on August 13, 2019, and the previous nonflood survey on June 2, 2015 (fig. 23), indicates about 99 percent of the joint area of interest had detectable change, which means only 1 percent of the differences in the joint area of interest are equivocal and within the uncertainty. However, bed variation seems about equal between scour and deposition throughout the channel from 2015 to 2019 in the DoD map because deposition on the upstream left (north) side is balanced with scour in the middle (fig. 23). The average difference between the bathymetric surfaces was $-0.13 \mathrm{ft}$ (table 7), indicating minimal channel degradation between the 2015 and 2019 surveys. The net volume of cut in the reach from 2015 to 2019 was about $74,200 \mathrm{yd}^{3}$, and the net volume of fill was about $67,000 \mathrm{yd}^{3}$, resulting in a net loss of about 7,200 $\mathrm{yd}^{3}$ of sediment between 2015 and 2019. The cross sections from the two surveys along the upstream face of the bridge are similar (fig. 22); there is deposition on the left end of the section and there is nearly uniform lowering of about $5 \mathrm{ft}$ for most of the rest of the cross section. The frequency distribution of bed elevations in 2019 was wider than 2015 because a higher percentage of cells are at lower and higher channel-bed elevations (fig. 21). The scour hole near main channel pier 2 was of a similar shape in 2019 and 2015 (fig. 22) but slightly deeper on the right (south) side as evidenced by the area of scour around that side of the pier in the DoD map (fig. 23). The stone revetment and bedrock outcrops on the right (south) bank showed signs of nearly uniform minor deposition throughout the surveyed reach (fig. 23). As with previous DoD maps, substantial deposition or scour apparent at the faces of the pier footing results from minor horizontal positional variances between the surveys (see "Uncertainty Estimation" section).

The difference between the survey on August 13, 2019, and the previous flood survey on July 17, 2011 (fig. 24), indicates about 83 percent of the joint area of interest had detectable change, which means about 17 percent of the differences in the joint area of interest are equivocal and within the uncertainty. Substantial bed variation is apparent from 2011 to 2019 in the DoD map, and scour was predominant throughout the reach except for moderate deposition in some localized scoured areas near the piers and the trough of a large dune present in the 2011 survey (Huizinga, 2012; fig. 24). The average difference between the bathymetric surfaces was $-4.91 \mathrm{ft}$ (table 7), indicating substantial net channel degradation between the 2011 and 2019 surveys. The net volume of cut in the reach from 2011 to 2019 was about $216,700 \mathrm{yd}^{3}$, and the net volume of fill was about $6,000 \mathrm{yd}^{3}$, resulting in a net loss of about 210,700 $\mathrm{yd}^{3}$ of sediment between 2011 and 2019. The cross sections from the two surveys along the upstream face of the bridge are substantially different except along the left side of the scour hole near pier 2 and on the right bank (fig. 22). The frequency distribution of bed elevations in 2019 was similar in shape to 2011 but with a higher percentage of cells 


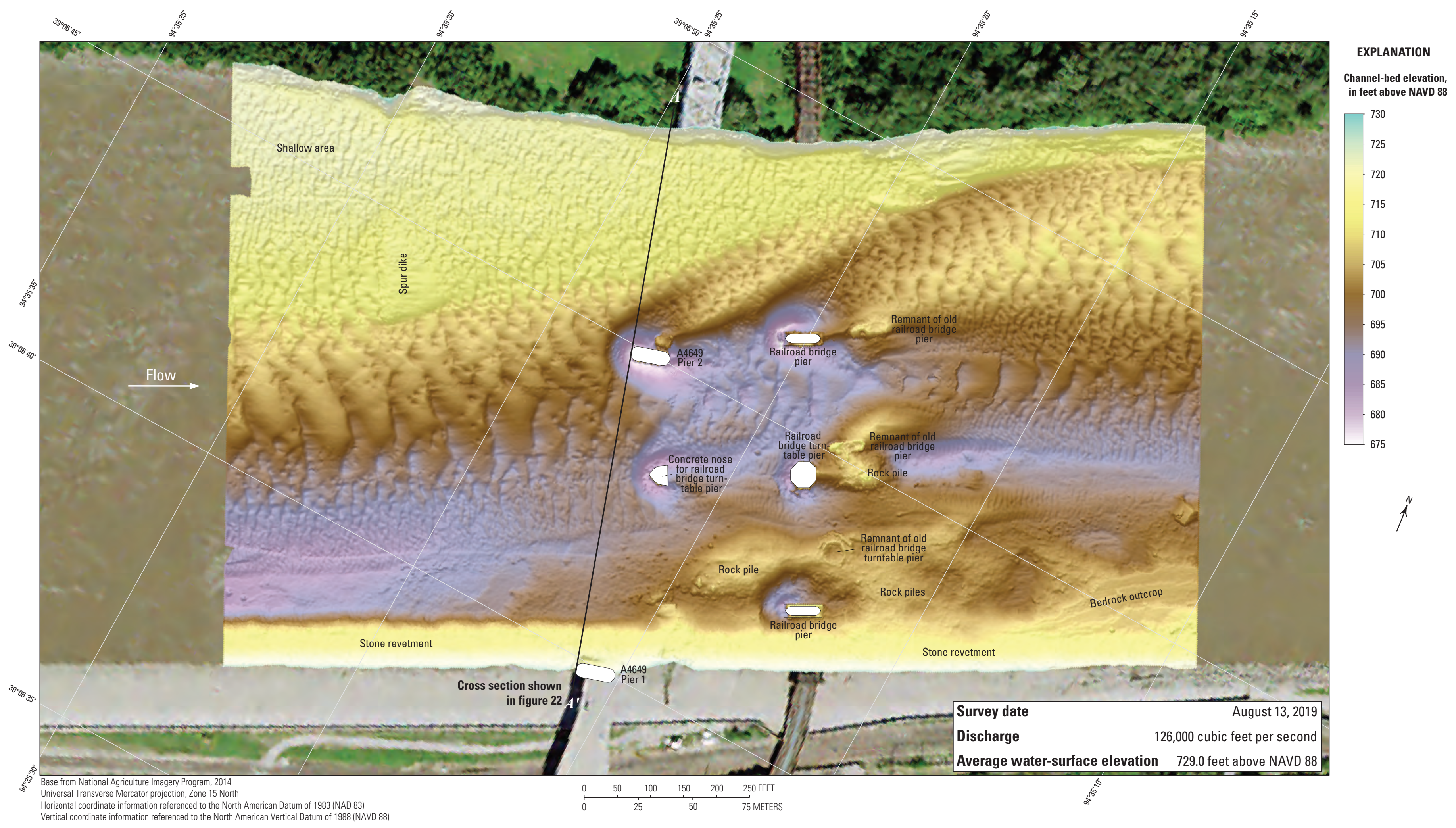

Figure 20. Bathymetric survey of the Missouri River channel near structure A4649 on U.S. Highway 169 in Kansas City, Missouri, on August 13, 2019 

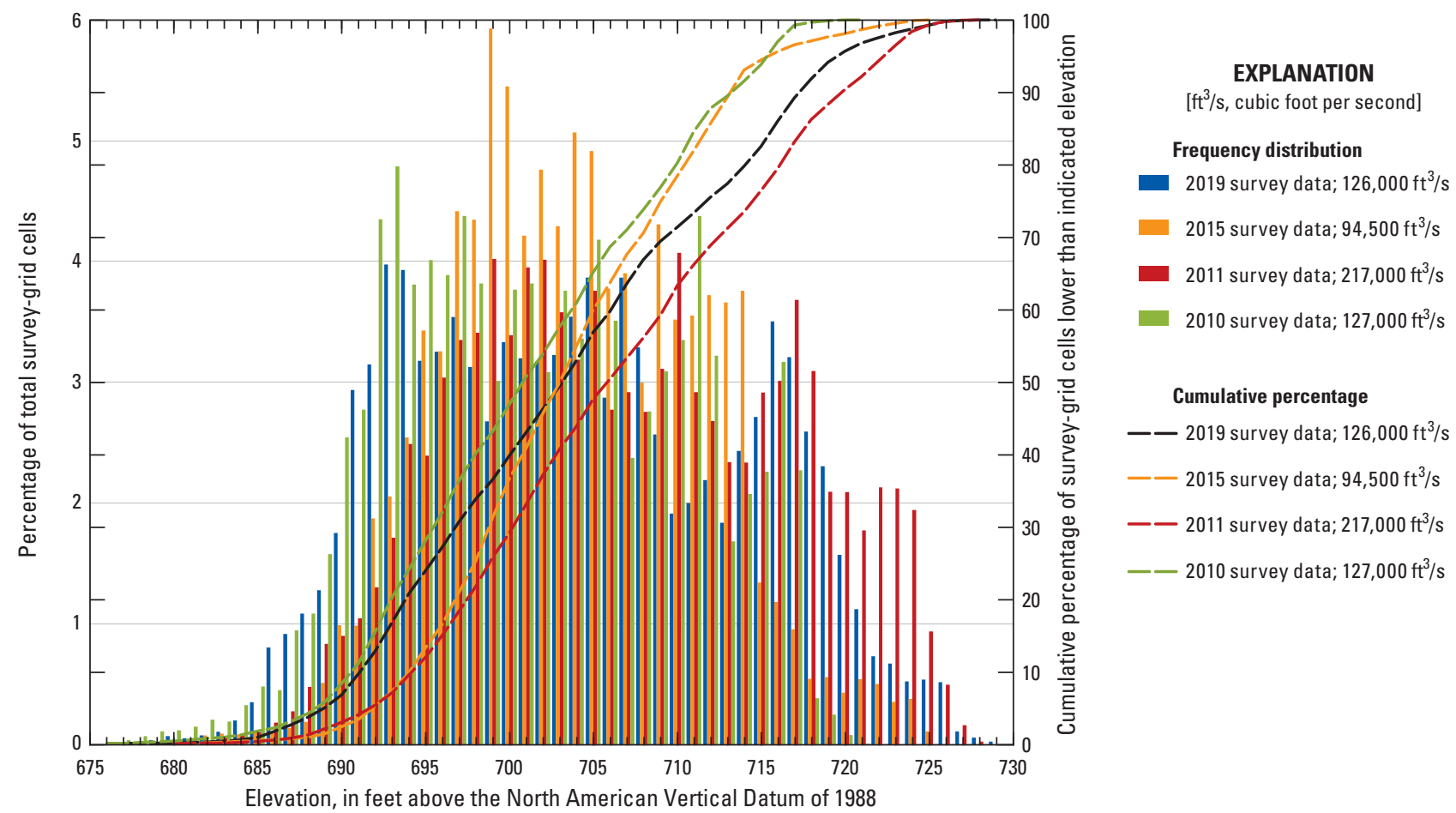

Figure 21. Frequency distribution of bed elevations for bathymetric survey-grid cells in 1-foot elevation bins on the Missouri River near structure A4649 on U.S. Highway 169 in Kansas City, Missouri, on August 13, 2019, compared to previous surveys in 2010, 2011, and 2015 (Huizinga, 2010, 2012, 2016, respectively). 


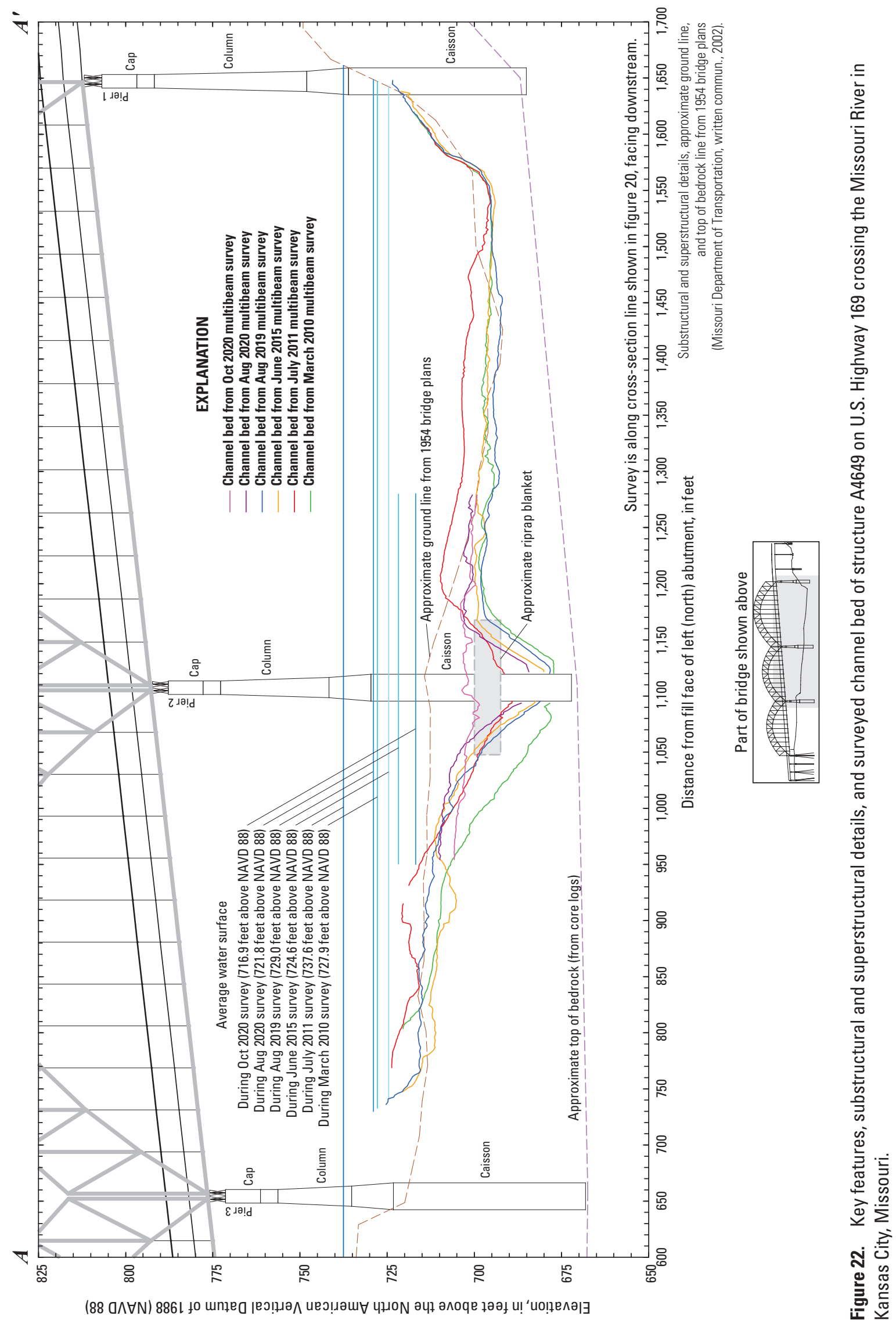




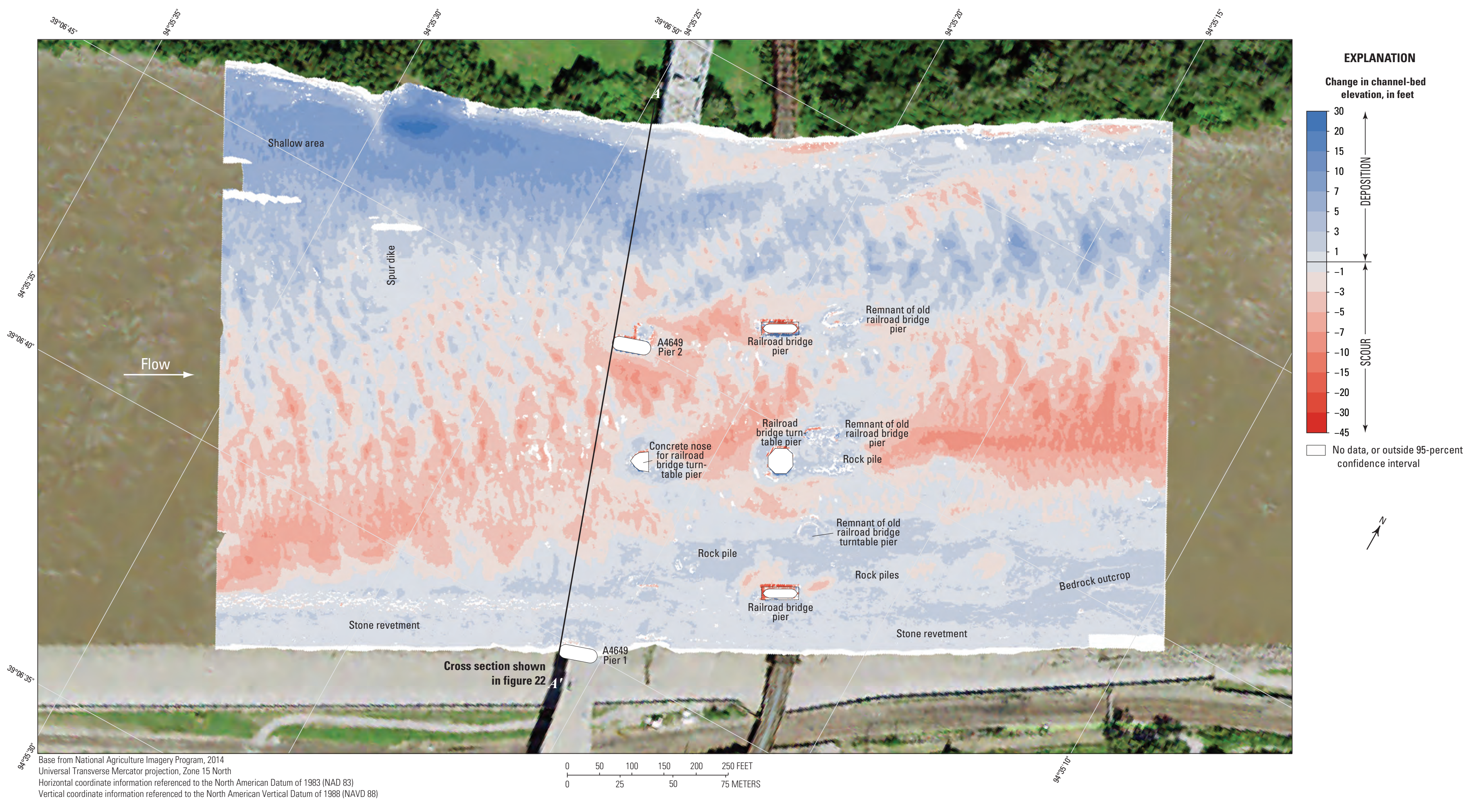

Figure 23. Difference between surfaces created from bathymetric surveys of the Missouri River channel near structure A4649 on U.S. Highway 169 in Kansas City, Missouri, on August 13, 2019 , and June 22, 2015. 


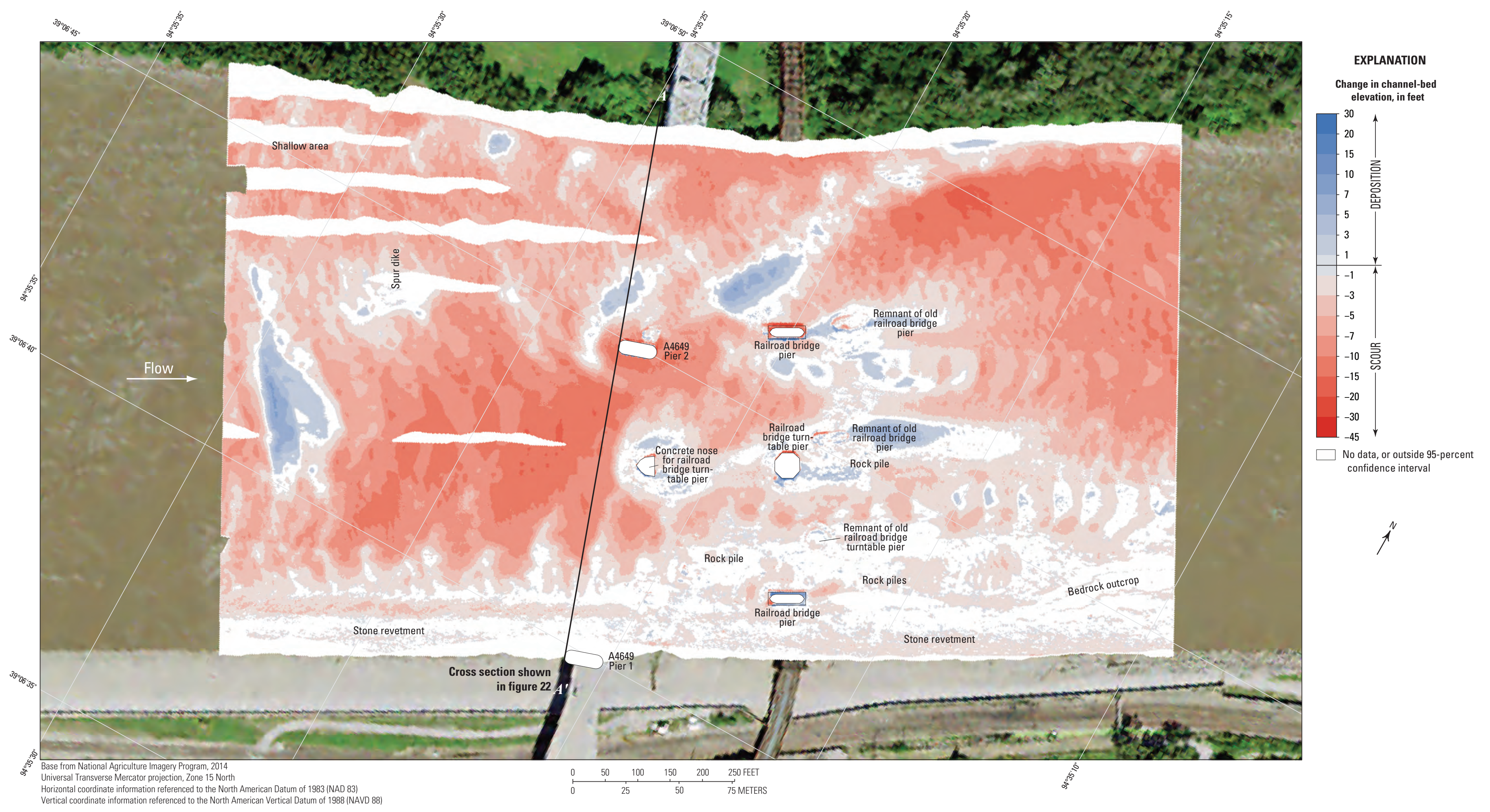

Figure 24. Difference between surfaces created from bathymetric surveys of the Missouri River channel near structure A4649 on U.S. Highway 169 in Kansas City, Missouri, on August 13, 2019 , and July 17, 2011. 
at lower elevations than in 2011 (fig. 21). The stone revetment and bedrock outcrops on the right (south) bank showed signs of localized scour in the DoD map, but much of the difference on the tops of the bedrock outcrop was within the uncertainties of the data (fig. 24). As with previous DoD maps, substantial deposition or scour apparent at the faces of the pier footing results from minor horizontal positional variances between the surveys (see "Uncertainty Estimation" section).

The difference between the survey on August 13, 2019, and the earliest nonflood survey on March 16, 2010 (fig. 25), indicates about 74 percent of the joint area of interest had detectable change, which means about 26 percent of the differences in the joint area of interest are equivocal and within the uncertainty. Bed variation seemed about equal between scour and deposition from 2010 to 2019 in the DoD map, deposition was predominant along the left (north) side of the channel, and scour was predominant along the right (south) side (fig. 25). The average difference between the bathymetric surfaces was $+0.75 \mathrm{ft}$ (table 7), indicating minor channel aggradation between the 2010 and 2019 surveys. The net volume of cut in the reach from 2010 to 2019 was about $45,200 \mathrm{yd}^{3}$, and the net volume of fill was about $72,800 \mathrm{yd}^{3}$, resulting in a net gain of about 27,600 $\mathrm{yd}^{3}$ of sediment between 2010 and 2019. The cross sections from the two surveys along the upstream face of the bridge are substantially different from one another for most of the section to the left of pier 2 and are more similar to one another to the right of pier 2 (fig. 22). The frequency distribution of bed elevations in 2019 was similar in shape but narrower than 2010 (fig. 21); however, the surveyed area was substantially wider in 2019 than in 2010 and extended higher on the channel banks. The stone revetment and bedrock outcrops on the right (south) bank showed signs of more substantial localized scour in the upstream reach in the DoD map, but much of the difference on the tops of the downstream bedrock outcrop was within the uncertainties of the data (fig. 25). As with previous DoD maps, substantial deposition or scour apparent at the faces of the pier footing results from minor horizontal positional variances between the surveys (see "Uncertainty Estimation" section).

The vertically averaged velocity vectors indicate mostly uniform flow upstream from the structure A4649 ranging from a minimum of $2 \mathrm{ft} / \mathrm{s}$ along the inside of the bend on the upstream left (north) bank to a maximum velocity of about $10 \mathrm{ft} / \mathrm{s}$ in the channel thalweg along the outside of the bend on the right (south) bank, particularly near the bridges (fig. 26). Exceptions to uniform conditions include diagonal flows across the channel near structure A4649 (fig. 26), which may help explain the shift in the channel thalweg towards the left (north) bank through the reach. Substantial turbulence also was observed between structure A4649 and the railroad bridge and downstream from the railroad bridge piers (fig. 26). The rock piles near the right bank also appear to create turbulence (fig. 26).

The history of scour observed near pier 2 (Huizinga, $2010,2012,2016$ ), and the nature of caisson foundations generally not being embedded in bedrock led MoDOT to install scour countermeasures around pier 2 during AugustOctober 2020. Partial surveys of the channel bed near pier 2 of structure A4649 were done before and after installation of these scour countermeasures to document and verify installation. The historical scour hole near pier 2 was clearly evident in the pre-installation survey on August 17, 2020 (fig. 27), but the difference between the survey on August 13, 2019, and the partial survey on August 17, 2020, indicates moderate deposition of 5 to $10 \mathrm{ft}$ had occurred from 2019 to 2020 (fig. 28). The cross sections from the two surveys along the upstream face of the bridge also indicates this deposition from 2019 to 2020 (fig. 22). The downstream edge of riprap blanket countermeasures installed around pier 2 was clearly evident in the postinstallation survey on October 23, 2020 (figs. 29, 1.4B), and the difference between the pre- and post-installation surveys indicate the changes resulting from the installation (fig. 30). The net volume of cut in the partial reach from August 2019 to August 2020 was about $750 \mathrm{yd}^{3}$, and the net volume of fill was about $18,660 \mathrm{yd}^{3}$, resulting in a net gain of about $17,910 \mathrm{yd}^{3}$ of sediment between August 2019 and August 2020 (fig. 28). However, the net volume of cut in the partial reach from August to October 2020 was about $6,300 \mathrm{yd}^{3}$, and the net volume of fill was about $5,000 \mathrm{yd}^{3}$, resulting in a net loss of about $1,300 \mathrm{yd}^{3}$ of sediment between August and October 2020 (fig. 30), despite installation of the countermeasures. The scour hole was effectively mitigated, with as much as $20 \mathrm{ft}$ of deposition near the pier (fig. 30), including some deposition of material on top of the blanket upstream from the bridge (fig. 29); nevertheless, moderate scour occurred in much of the partial reach around the riprap blanket between August and October (fig. 30). 


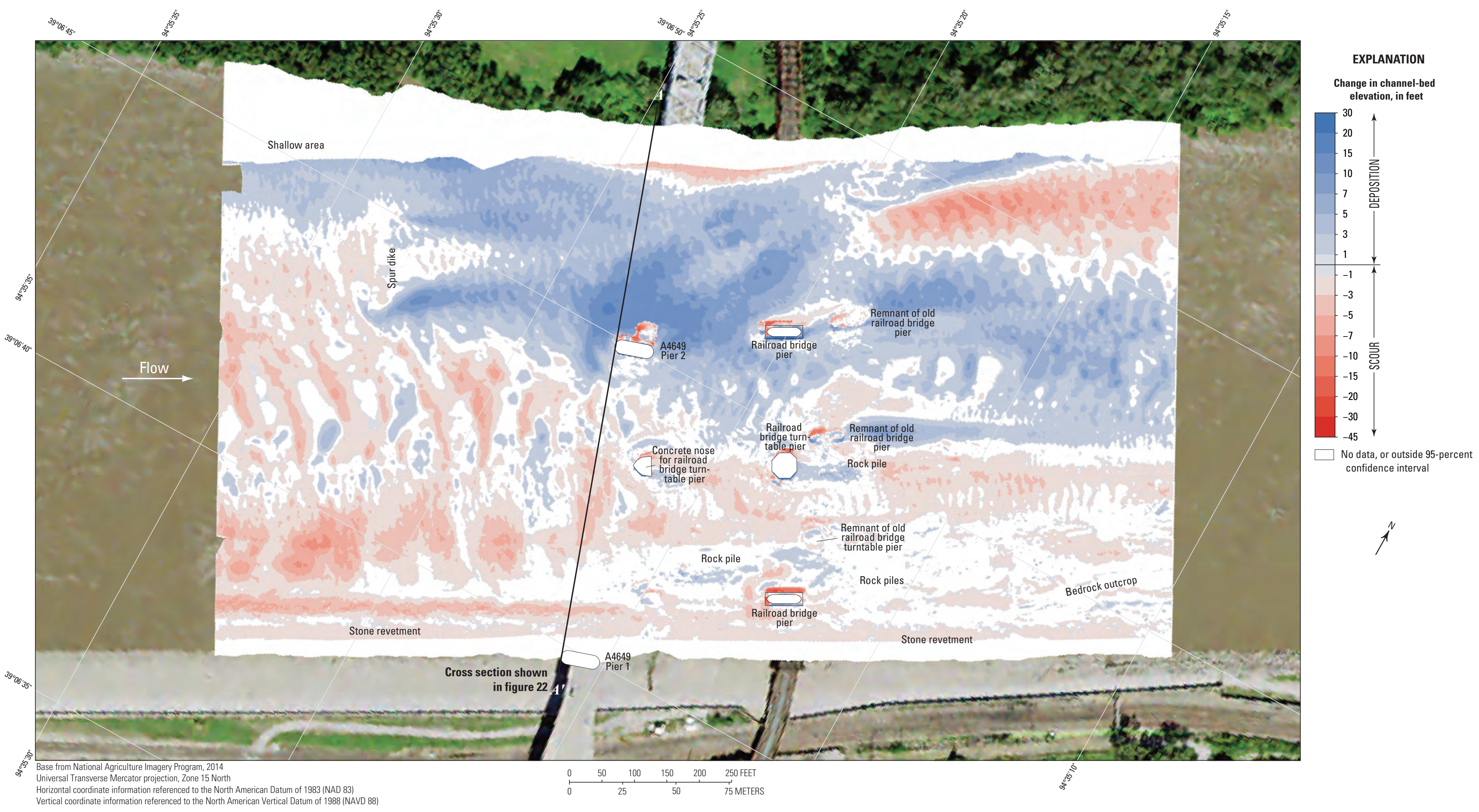

Figure 25. Difference between surfaces created from bathymetric surveys of the Missouri River channel near structure A4649 on U.S. Highway 169 in Kansas City, Missouri, on August 13, 2019, and March 16, 2010. 


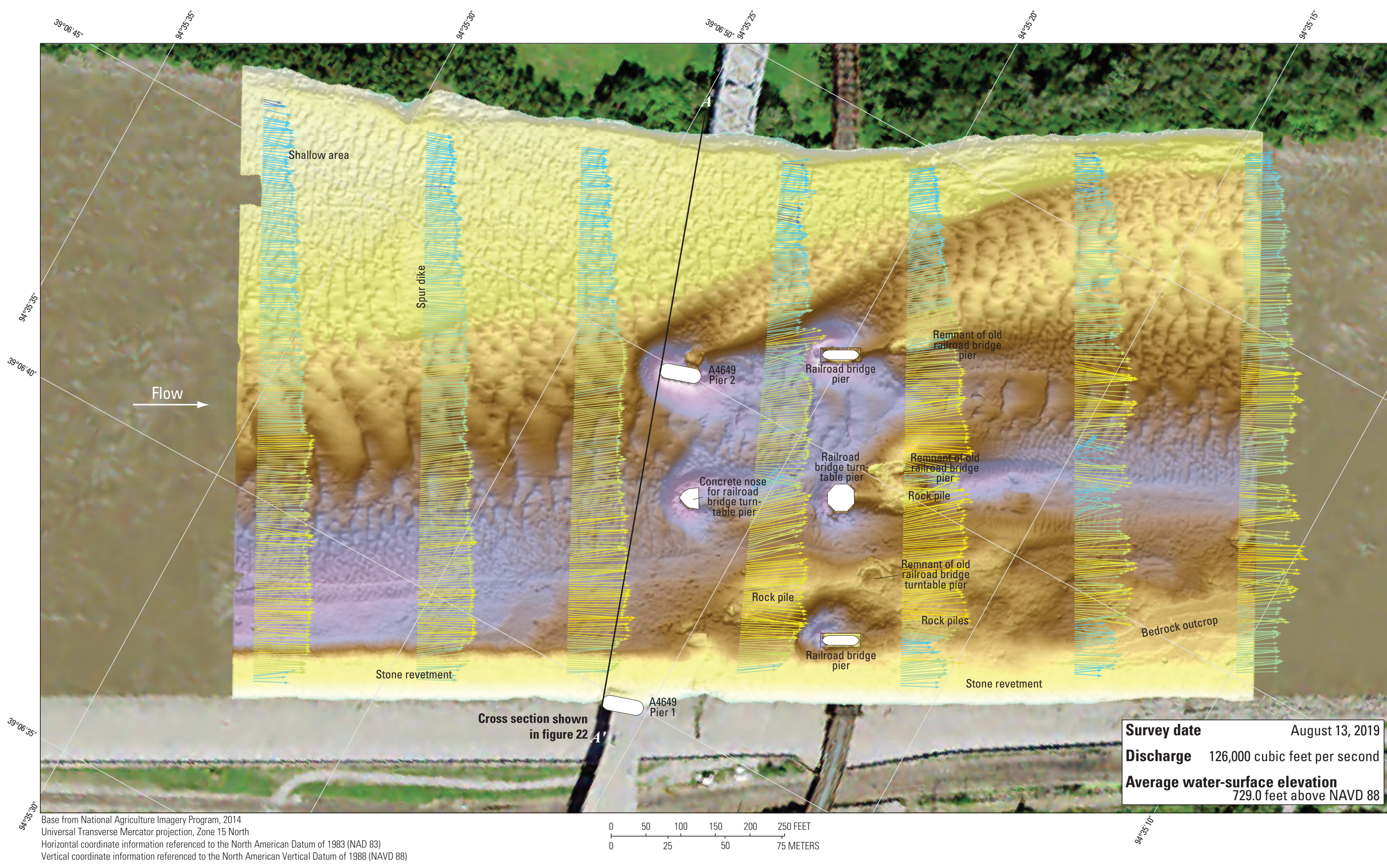

EXPLANATION

Channel-bed elevation,
in feet above NAVD 88

$\square^{730}$

725

.720

715

.710

705

705

695

675

Vertically averaged velocity,
in feet per second

in feet per secoor
0 to $1 \rightarrow$

0 to $1 \rightarrow$
$>1$ to $2 \rightarrow$
2.02

$>1$ to 2 —
$>2$ to $3 \longrightarrow$

$>3$ to 4

$>4$ to 5

$>5$ to 6
$>6$ to
$>7$ -

$>7$ to $8-$
$>8$ to $9-$
$>9$ to $10-$

$>9$ to $10 \longrightarrow$ $>11$ to

^ 


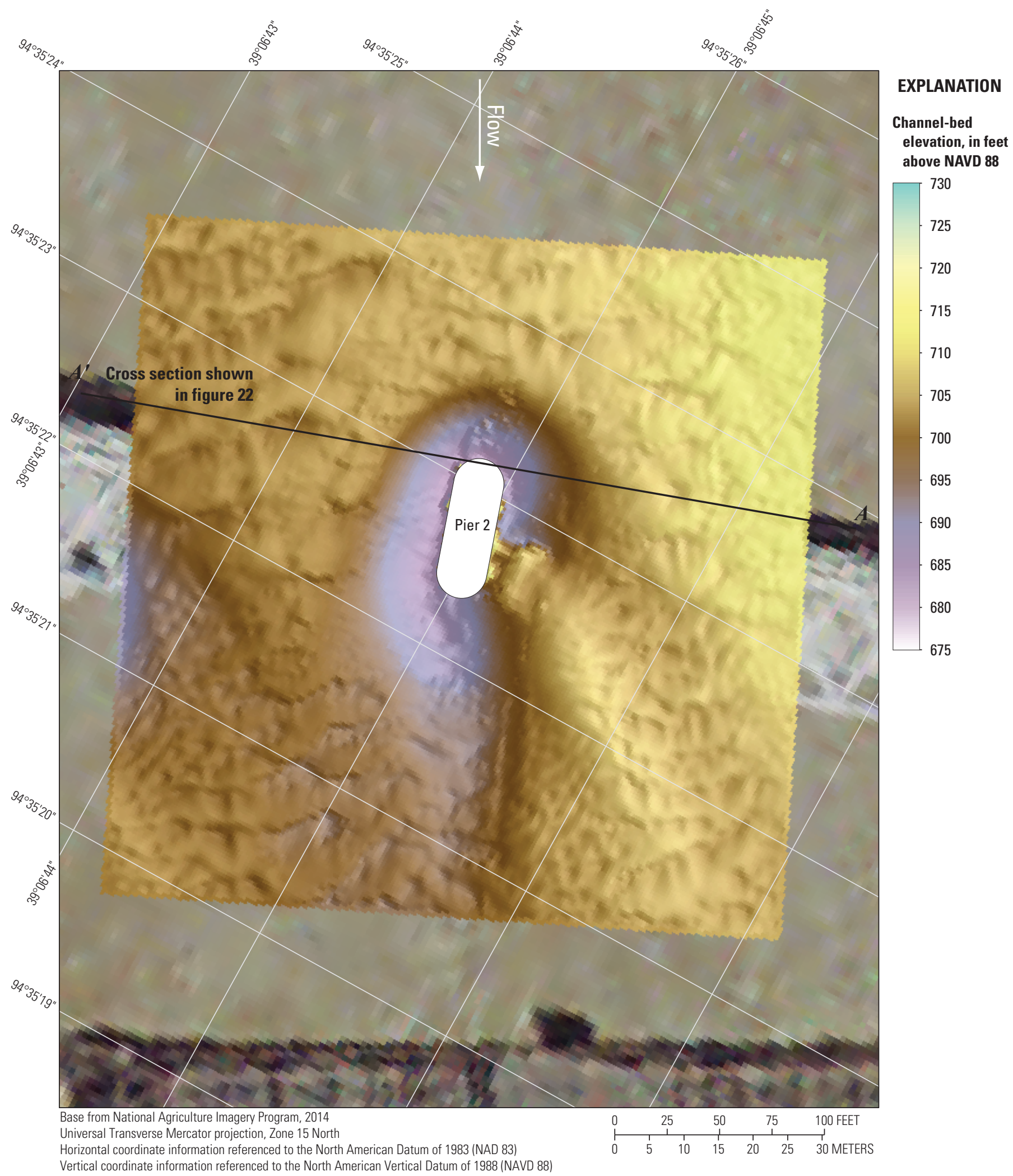

Figure 27. Bathymetric survey of the Missouri River channel near the main channel pier of structure A4649 on U.S. Highway 169 in Kansas City, Missouri, on August 17, 2020, before installation of scour countermeasures. 


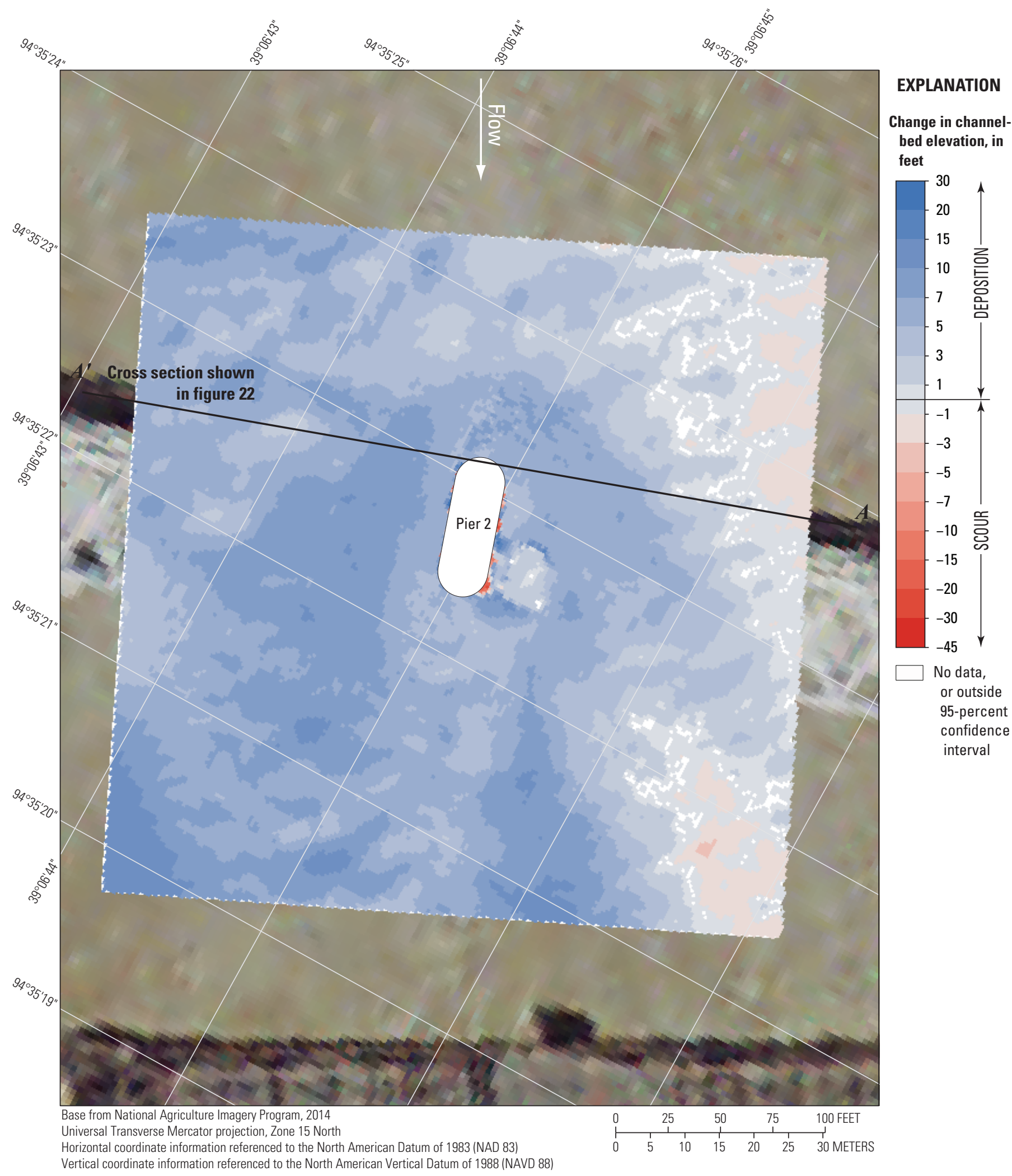

Figure 28. Difference between surfaces created from bathymetric surveys of the Missouri River channel near the main channel pier of structure A4649 on U.S. Highway 169 in Kansas City, Missouri, on August 13, 2019, and August 17, 2020, before installation of scour countermeasures. 


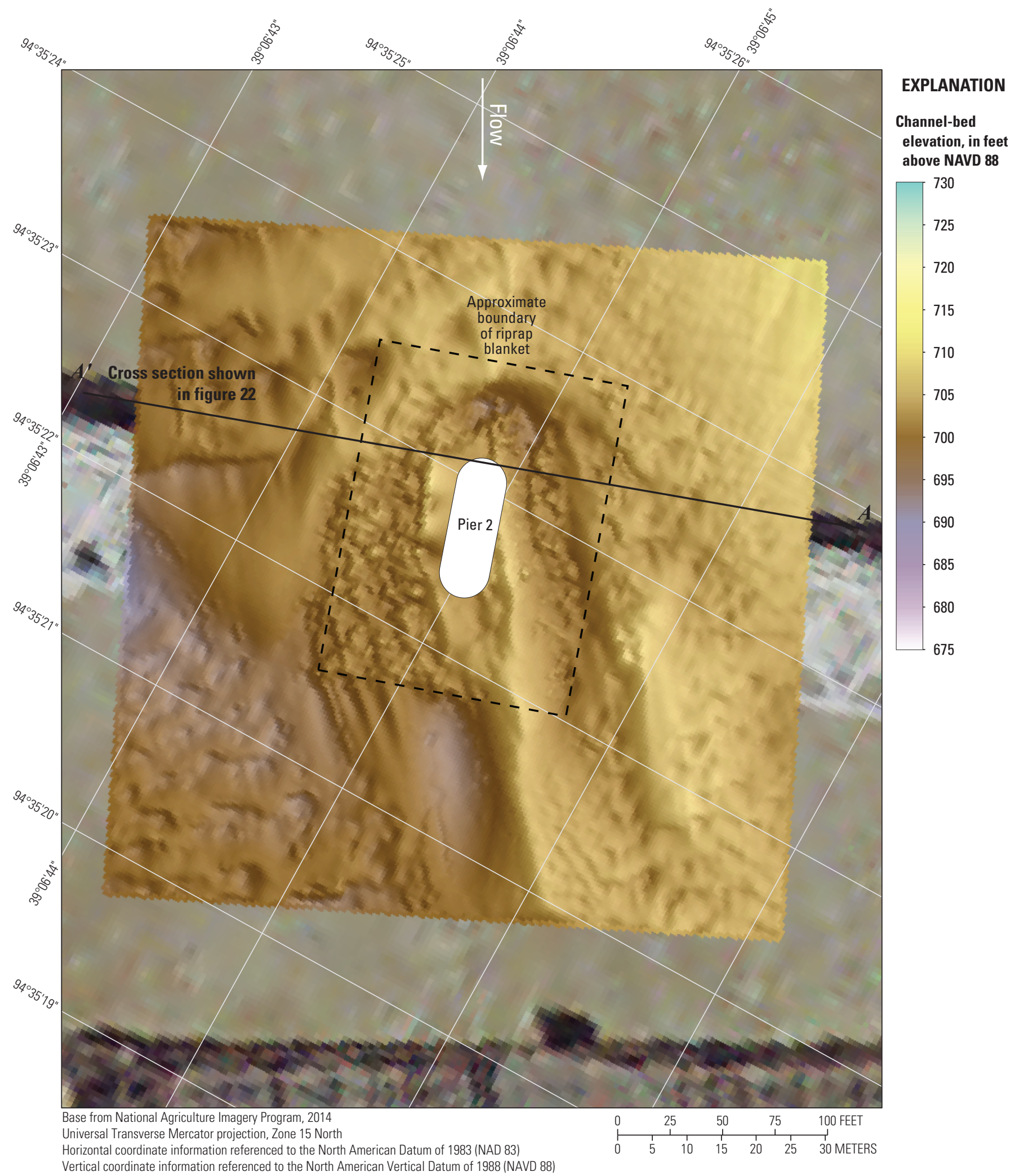

Figure 29. Bathymetric survey of the Missouri River channel near the main channel pier of structure A4649 on U.S. Highway 169 in Kansas City, Missouri, on October 23, 2020, after installation of scour countermeasures. 


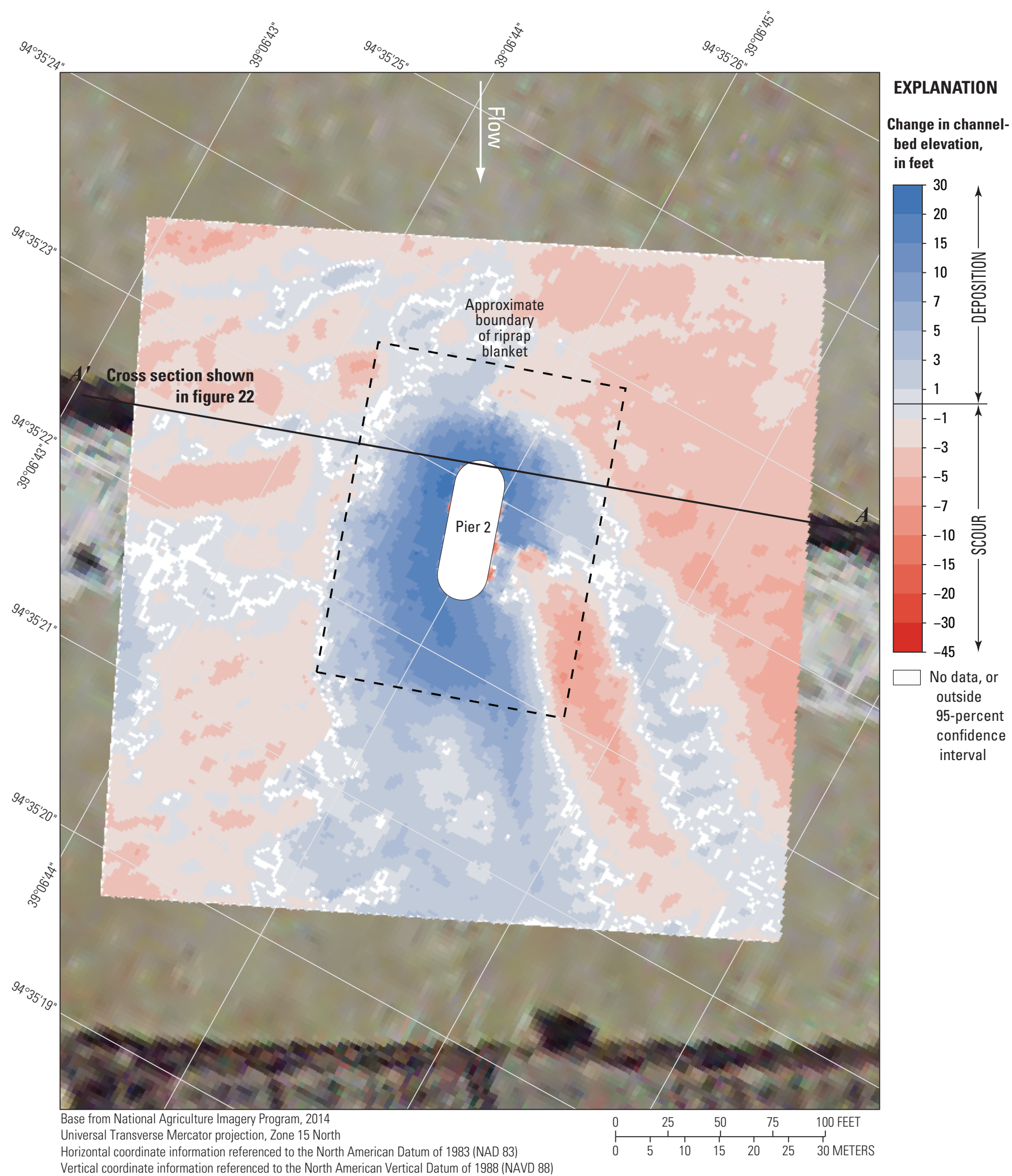

Figure 30. Difference between surfaces created from bathymetric surveys of the Missouri River channel near the main channel pier of structure A4649 on U.S. Highway 169 in Kansas City, Missouri, on August 17 and October 23, 2020, before and after installation of scour countermeasures. 


\section{Structure A4060 on State Highway 9}

Structure A4060 (site 9; table 1) on State Highway 9 crosses the Missouri River at RM 365.5, immediately north of downtown Kansas City, Mo. (fig. 1), and is about 3,400 ft downstream from structure A4649 (site 8) on U.S. Highway

169. The site was surveyed on August 13, 2019, and the average water-surface elevation of the river in the survey area, determined by the RTK GPS tide solution, was $728.2 \mathrm{ft}$ (table 5; fig. 31). Streamflow on the Missouri River was about $126,000 \mathrm{ft}^{3} / \mathrm{s}$ during the survey (table 5).

The survey area was about 1,640 ft long and averaged about $900 \mathrm{ft}$ wide, extending from bank to bank in the main channel (fig. 31). Piers 5 and 6 were in the water and away from the banks, and the upstream end of the survey area was about $665 \mathrm{ft}$ upstream from the centerline of structure A4060 at pier 6 (fig. 31). The channel-bed elevations ranged from about 690 to $715 \mathrm{ft}$ for most of the surveyed area (5th to 95th percentile range of the bathymetric data; table 5; fig. 32), except near the railroad bridge pier upstream from pier 6 of structure A4060 (fig. 31). A shallow but wide thalweg along the right (south) side of the surveyed area was about 10 to $15 \mathrm{ft}$ deeper than the channel bed in the middle of the channel (fig. 31). A few medium dune features were detected in the middle of the channel upstream from the bridges, and numerous smaller dunes and ripples were present throughout the channel reach (fig. 31). As in previous surveys (Huizinga, 2010, 2012, 2016), a stone revetment was present on the right (south) bank throughout the reach (fig. 31).

Erosion near the left (north) bank resulted in a scour hole near main channel pier 4 on that bank (figs. 31, 33) with a minimum channel-bed elevation of $699 \mathrm{ft}$ (table 6). A scour hole near main channel pier 5 (fig. 31) had a minimum channel-bed elevation of about $692 \mathrm{ft}$ (table 6), about $4 \mathrm{ft}$ below the elevation of the bottom of the pier seal course of $696.26 \mathrm{ft}$ (fig. 33; table 6). Near the right (south) main channel pier 6 (fig. 31), a scour hole had a minimum channel-bed elevation of about $687 \mathrm{ft}$ (table 6), about $9 \mathrm{ft}$ below the elevation of the bottom of the pier seal course of $696.26 \mathrm{ft}$ (fig. 33; table 6). A substantially deeper scour hole was observed near the upstream railroad bridge pier (fig. 31), with a minimum elevation of about $678 \mathrm{ft}$, which is the overall minimum channel-bed elevation observed in this reach (table 5). This deeper hole likely was the result of flow around the upstream railroad pier combine with flow over large sheet piling panels that were lying on the channel bottom on the right (south) side of pier first observed in the 2010 survey (Huizinga, 2010), and seen in all subsequent surveys (Huizinga 2012, 2016). Information from bridge plans indicates that piers 4 through 6 are founded on shafts drilled $20 \mathrm{ft}$ into bedrock, about $34 \mathrm{ft}$ of bed material were between the bottom of the scour hole and bedrock at pier 4, about $25 \mathrm{ft}$ of material were between the bottom of the scour hole and bedrock at pier 5, and about $17 \mathrm{ft}$ of material were between the bottom of the scour hole and bedrock at pier 6 (fig. 33; table 6).
The difference between the survey on August 13, 2019, and the previous nonflood survey on June 3, 2015 (fig. 34), indicates about 81 percent of the joint area of interest had detectable change, which means about 19 percent of the differences in the joint area of interest are equivocal and within the uncertainty. Substantial bed variation is apparent from 2015 to 2019 in the DoD map, with scour predominant throughout the reach except along the left (north) side of the channel (fig. 34). The average difference between the bathymetric surfaces was $-2.56 \mathrm{ft}$ (table 7), indicating moderate to substantial degradation between the 2015 and 2019 surveys. The net volume of cut in the reach from 2015 to 2019 was about $143,100 \mathrm{yd}^{3}$, and the net volume of fill was about $37,300 \mathrm{yd}^{3}$, resulting in a net loss of about 105,800 $\mathrm{yd}^{3}$ of sediment between 2015 and 2019. The cross sections from the two surveys along the upstream face of the bridge also indicate these differences (fig. 33); there is localized scour near the left (north) bank, and there is nearly uniform lowering of about $10 \mathrm{ft}$ between pier 6 and the right (south) bank. The frequency distribution of bed elevations in 2019 was wider than 2015, with a higher percentage of cells at lower and higher channel-bed elevations (fig. 32). The scour holes near main channel piers 5 and 6 were shallower on the left (north) side and deeper on the right (south) side of the pier as evidenced by the areas of deposition and scour near the piers in the DoD map (fig. 34). The scour of the left (north) bank near pier 4 also is clearly evident in the cross-section and DoD map (figs. 33, 34). The stone revetment on the right (south) bank showed signs of very minor localized deposition and scour throughout the surveyed reach (fig. 34); most of the differences on the right (south) bank were within the uncertainties of the data. As with previous DoD maps, substantial deposition or scour apparent at the faces of the pier footing results from minor horizontal positional variances between the surveys (see "Uncertainty Estimation" section).

The difference between the survey on August 13, 2019, and the previous flood survey on July 17, 2011 (fig. 35), indicates about 90 percent of the joint area of interest had detectable change, which means about 10 percent of the differences in the joint area of interest are equivocal and within the uncertainty. Substantial bed variation is apparent from 2011 to 2019 in the DoD map, and scour is predominant throughout the reach except for moderate deposition in some localized scoured areas near the piers and in the channel downstream from the bridges in the 2011 survey (Huizinga, 2012; fig. 35). The average difference between the bathymetric surfaces was $-3.64 \mathrm{ft}$ (table 7), indicating substantial net channel degradation between the 2011 and 2019 surveys. The net volume of cut in the reach from 2011 to 2019 was about $186,100 \mathrm{yd}^{3}$, and the net volume of fill was about $14,600 \mathrm{yd}^{3}$, resulting in a net loss of about 171,500 $\mathrm{yd}^{3}$ of sediment between 2011 and 2019. The cross sections from the two surveys along the upstream face of the bridge show some similarities near and between piers 5 and 6 and on the right (south) bank, and are substantially different elsewhere (fig. 33). The frequency distribution of bed elevations in 2019 was similar in shape to 2011, but with a higher percentage of cells at lower elevations than in 


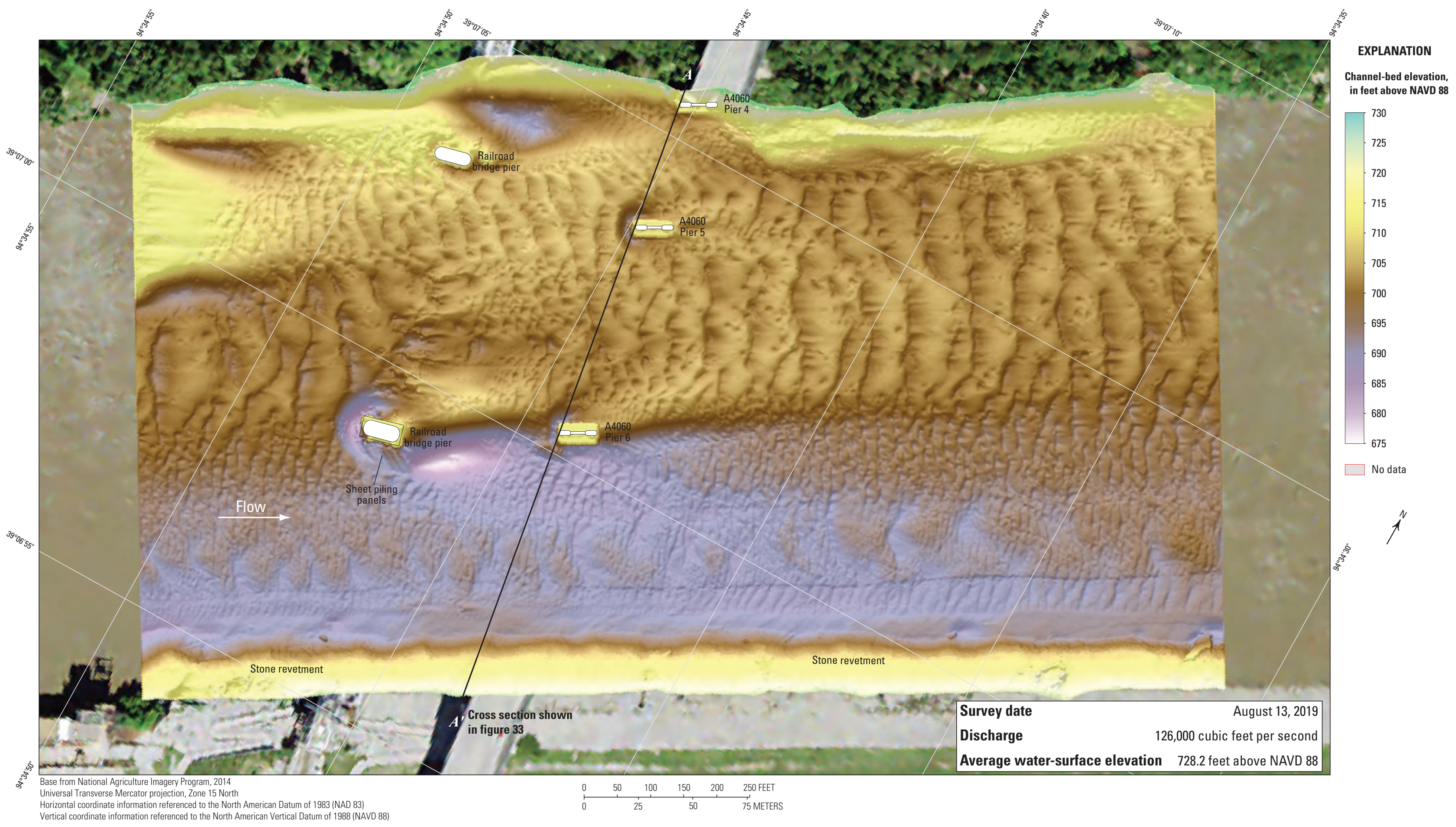

Figure 31. Bathymetric survey of the Missouri River channel near structure A4060 on State Highway 9 in Kansas City, Missouri, on August 13, 2019. 


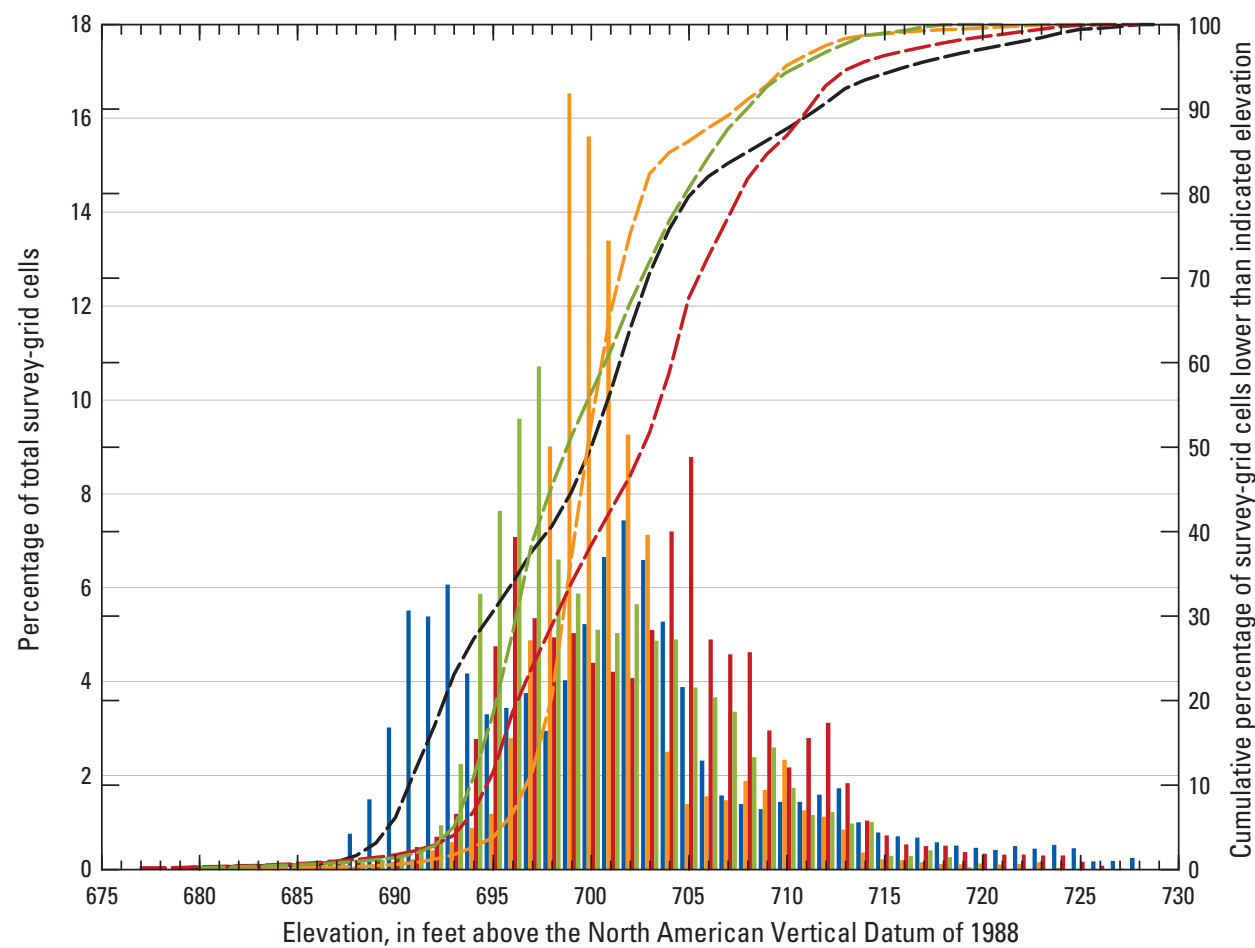

\section{EXPLANATION}

$\left[\mathrm{ft}^{3} / \mathrm{s}\right.$, cubic foot per second]

\section{Frequency distribution}

2019 survey data; $126,000 \mathrm{ft}^{3} / \mathrm{s}$

2015 survey data; $93,900 \mathrm{ft}^{3} / \mathrm{s}$

2011 survey data; $217,000 \mathrm{ft}^{3} / \mathrm{s}$

2010 survey data; $126,000 \mathrm{ft}^{3} / \mathrm{s}$

Cumulative percentage

- 2019 survey data; $126,000 \mathrm{ft}^{3} / \mathrm{s}$

—— 2015 survey data; $93,900 \mathrm{ft}^{3} / \mathrm{s}$

- 2011 survey data; $217,000 \mathrm{ft}^{3} / \mathrm{s}$

- 2010 survey data; $126,000 \mathrm{ft}^{3} / \mathrm{s}$

Figure 32. Frequency distribution of bed elevations for bathymetric survey-grid cells in 1-foot elevation bins on the Missouri River near structure A4060 on State Highway 9 in Kansas City, Missouri, on August 13, 2019, compared to previous surveys in 2010, 2011, and 2015 (Huizinga, 2010, 2012, 2016, respectively). 


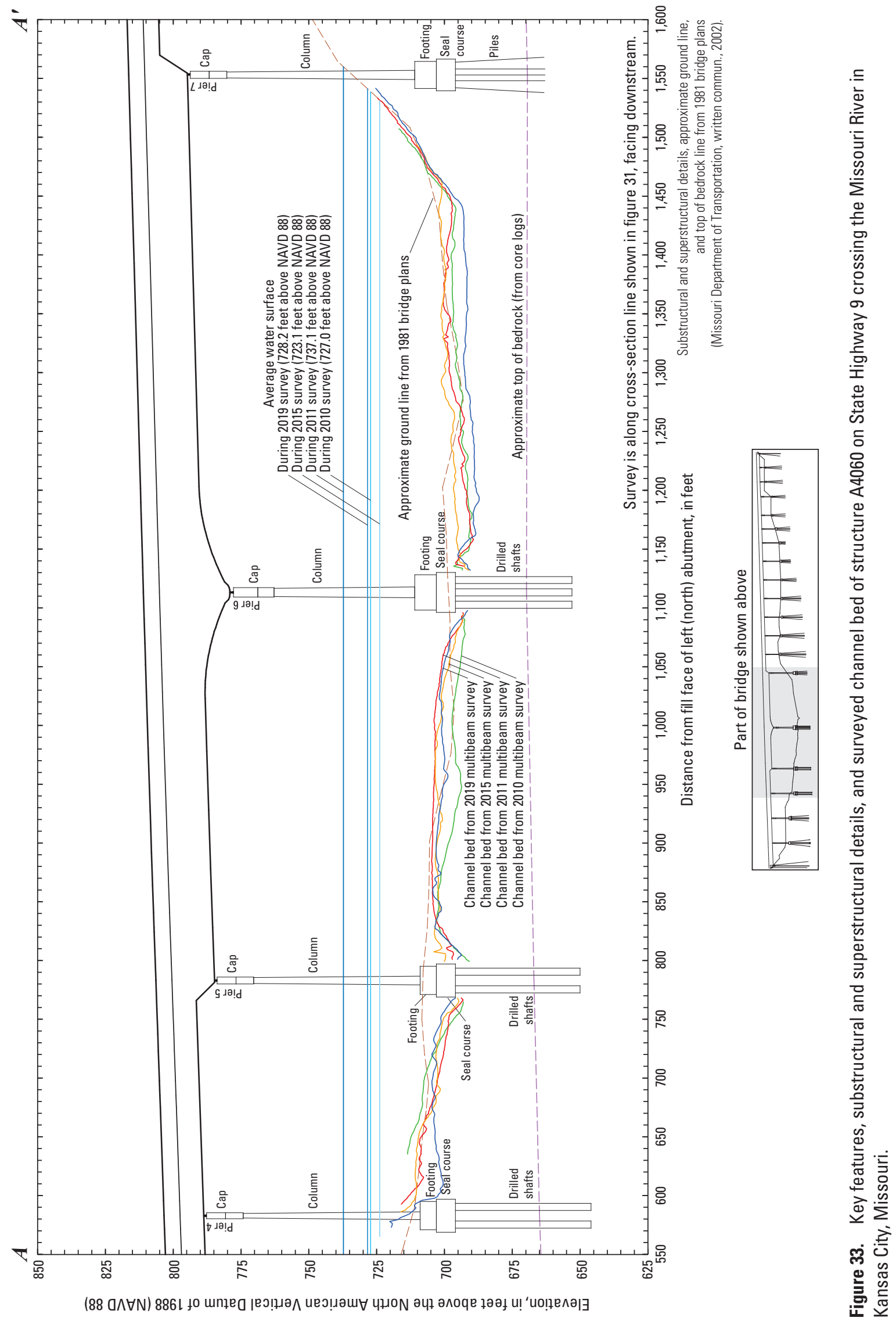




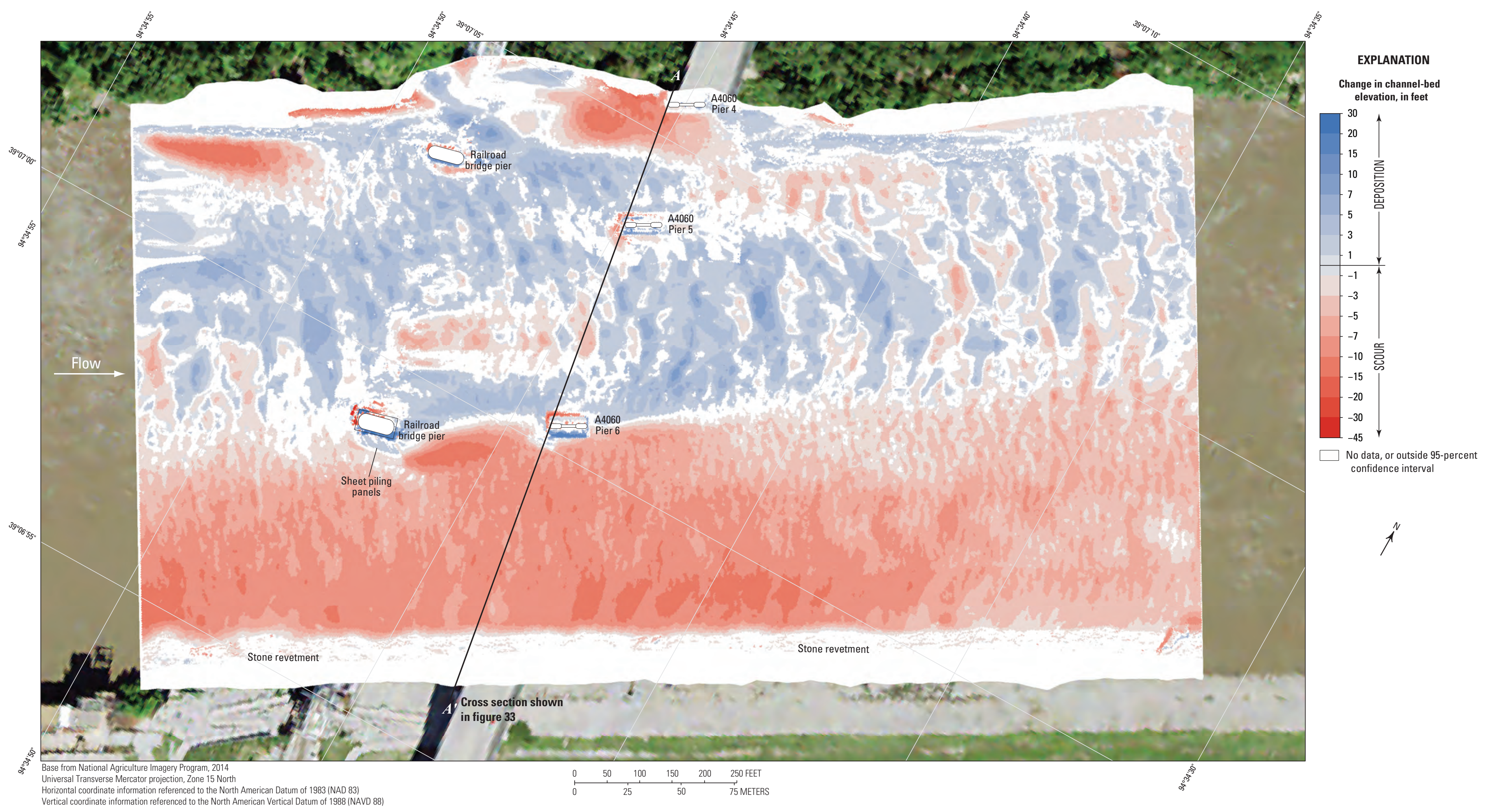

Figure 34. Difference between surfaces created from bathymetric surveys of the Missouri River channel near structure A4060 on State Highway 9 in Kansas City, Missouri, on August 13, 2019 , and June 3, 2015. 


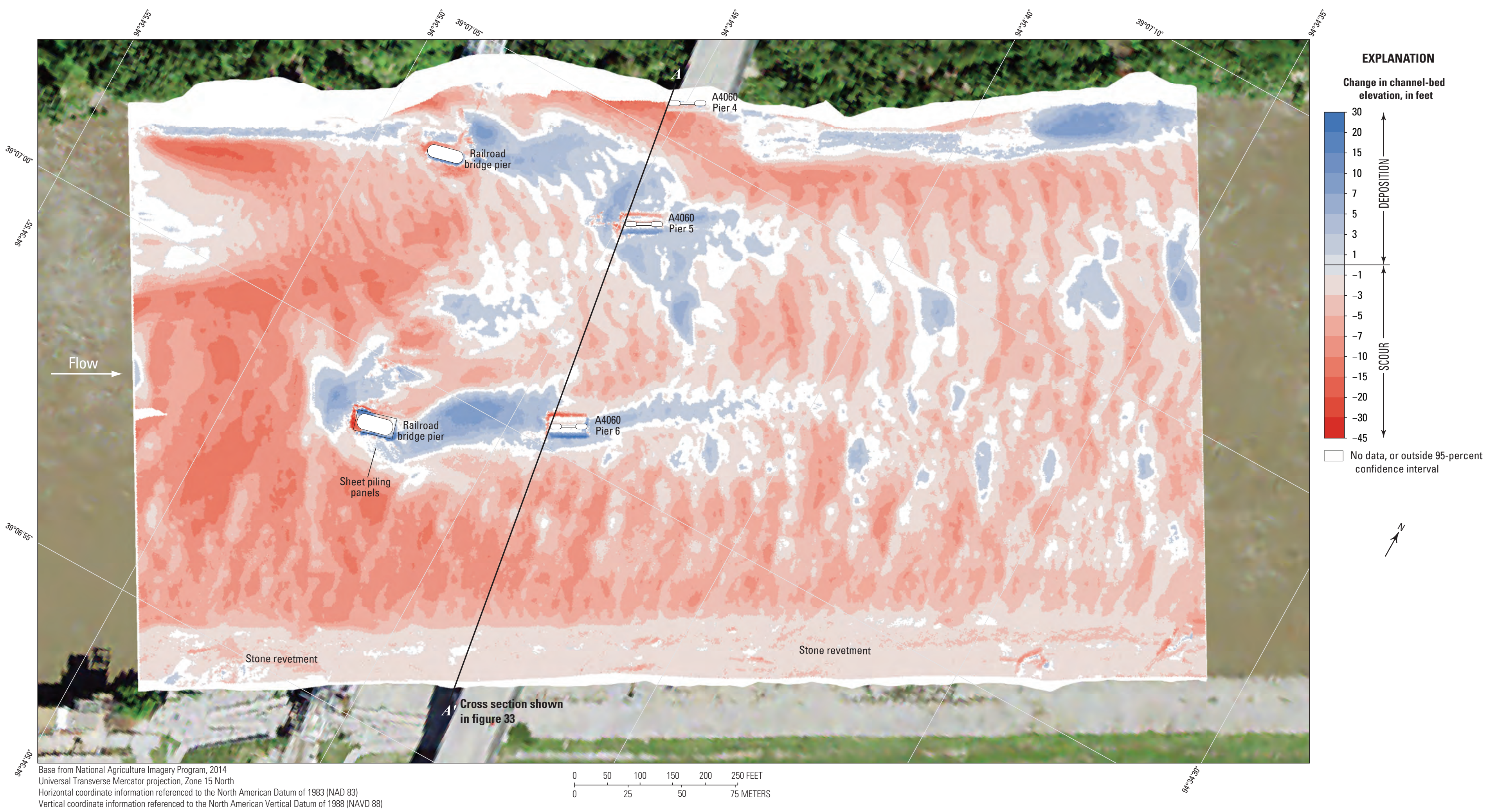

Figure 35. Difference between surfaces created from bathymetric surveys of the Missouri River channel near structure A4060 on State Highway 9 in Kansas City, Missouri, on August 13, 2019, and July 17, 2011. 
2011 (fig. 32). The stone revetment on the right (south) bank showed signs of nearly uniform minor scour in the DoD map (fig. 35). As with previous DoD maps, substantial deposition or scour apparent at the faces of the pier footing results from minor horizontal positional variances between the surveys (see "Uncertainty Estimation" section).

The difference between the survey on August 13, 2019, and the earliest nonflood survey on March 16, 2010 (fig. 36), indicates about 85 percent of the joint area of interest had detectable change, which means about 15 percent of the differences in the joint area of interest are equivocal and within the uncertainty. Bed variation seemed more equal between scour and deposition from 2010 to 2019 in the DoD map than in the other DoD maps, deposition was predominant along the left (north) side of the channel, and scour was predominant along the right (south) side (fig. 36). However, the average difference between the bathymetric surfaces was $-1.58 \mathrm{ft}$ (table 7), indicating minor to moderate channel degradation between the 2010 and 2019 surveys. The net volume of cut in the reach from 2010 to 2019 was about $109,900 \mathrm{yd}^{3}$, and the net volume of fill was about $44,200 \mathrm{yd}^{3}$, resulting in a net loss of about
$65,700 \mathrm{yd}^{3}$ of sediment between 2010 and 2019. The cross sections from the two surveys along the upstream face of the bridge are substantially different from one another for most of the section, except near pier 5 and the right (south) bank (fig. 33). The frequency distribution of bed elevations in 2019 was similar in shape but slightly wider than 2010 (fig. 32); however, the surveyed area was substantially wider in 2019 than in 2010 and extended higher on the channel banks. The stone revetment on the right (south) bank showed signs of more substantial localized scour in the upstream reach in the DoD map (fig. 36). As with previous DoD maps, substantial deposition or scour apparent at the faces of the pier footing results from minor horizontal positional variances between the surveys (see "Uncertainty Estimation" section).

The vertically averaged velocity vectors indicate mostly uniform flow throughout the channel, ranging from about 1 to $9 \mathrm{ft} / \mathrm{s}$ (fig. 37). Exceptions to uniform conditions include substantial turbulence observed downstream from the railroad and highway bridge piers, and near the upstream left (north) bank (fig. 37). 


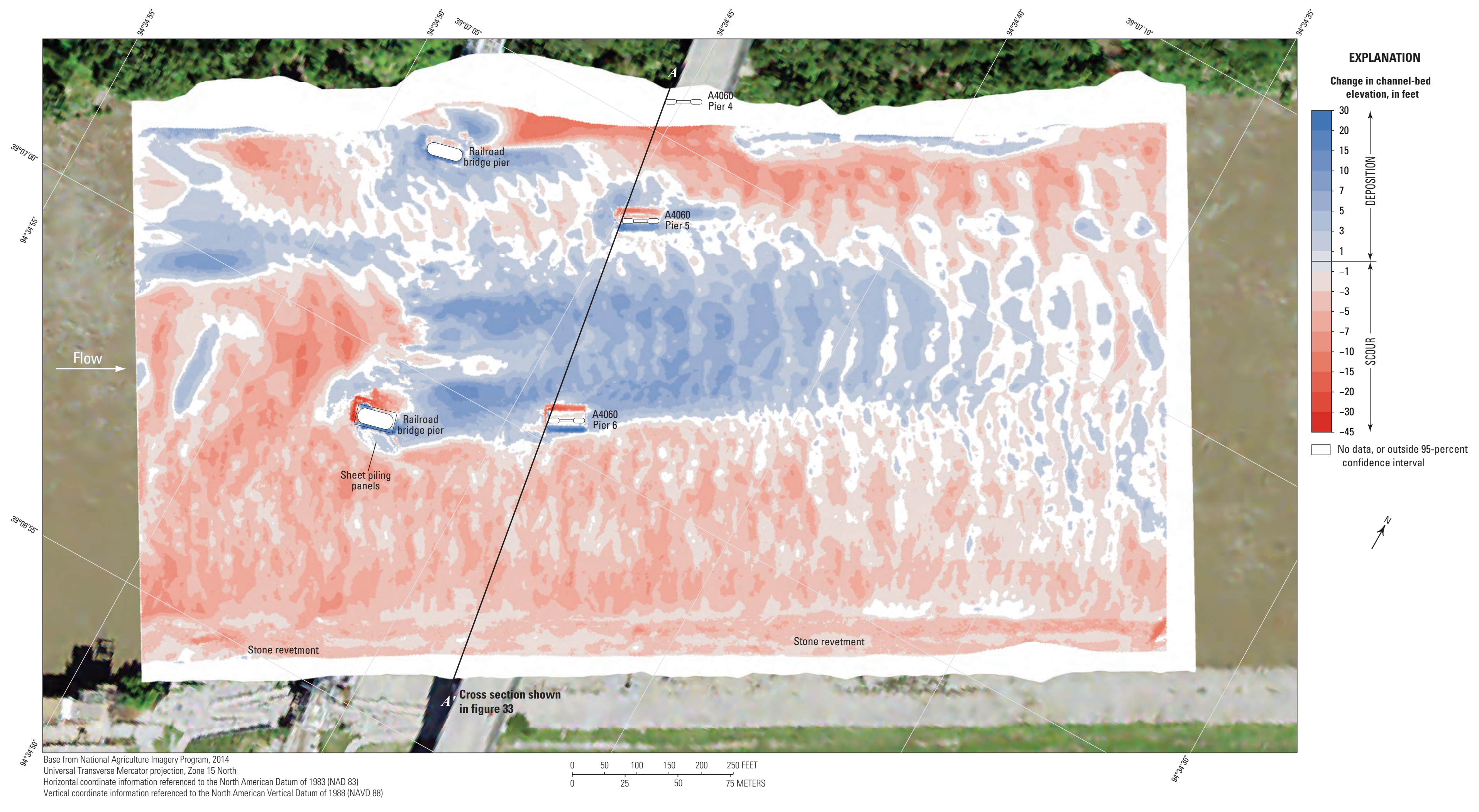

Figure 36. Difference between surfaces created from bathymetric surveys of the Missouri River channel near structure A4060 on State Highway 9 in Kansas City, Missouri, on August 13, 2019 , and March 16, 2010. 


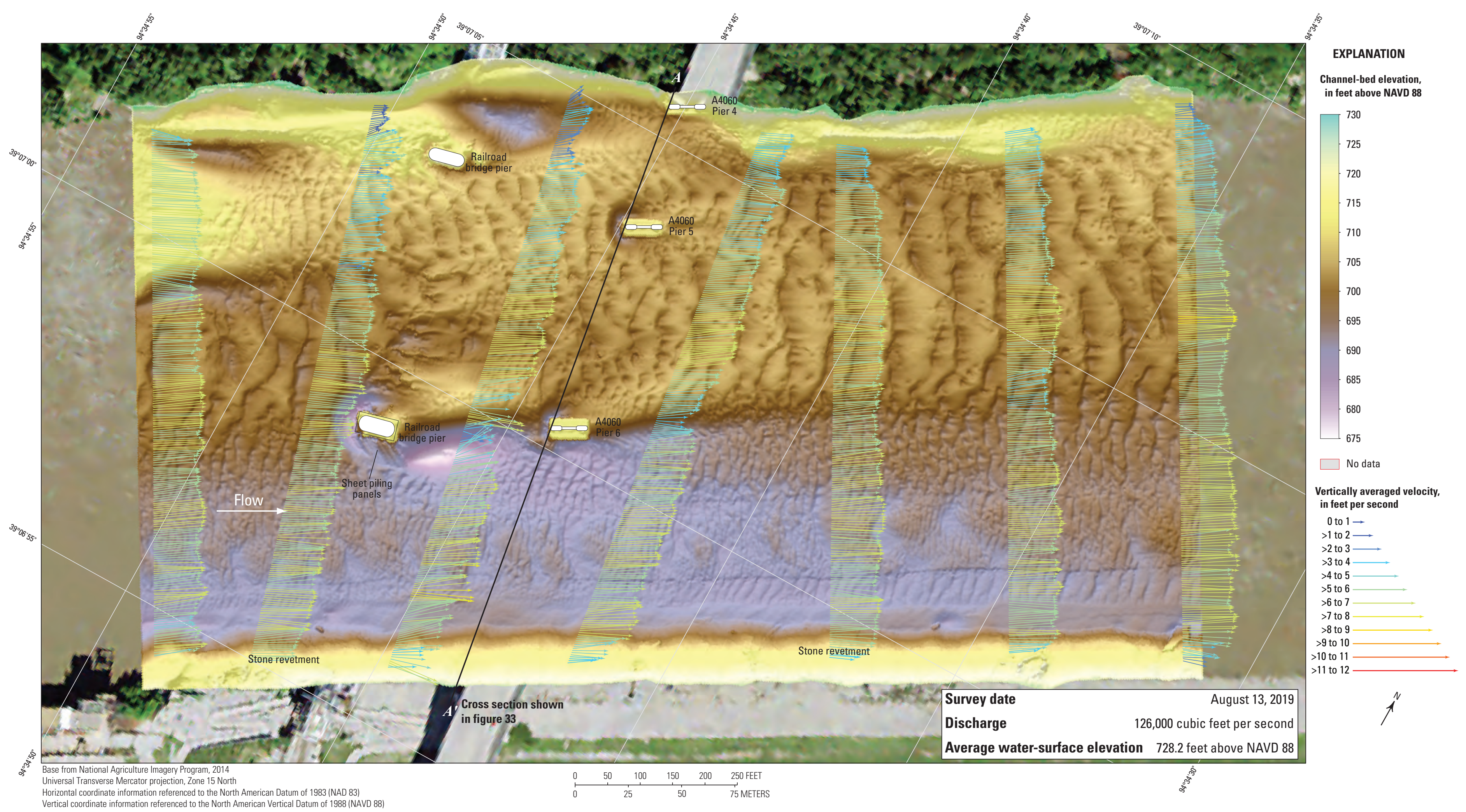

Figure 37. Bathymetry and vertically averaged velocities of the Missouri River channel near structure A4060 on State Highway 9 in Kansas City, Missouri, on August 13, 2019. 


\section{Structure A7650 on Interstate 35}

Structure A7650 (site 10; table 1) on Interstate 35 crosses the Missouri River at RM 364.7, immediately north of downtown Kansas City, Mo. (fig. 1), and is about 4,300 ft downstream from structure A4060 on State Highway 9 (site 9). The site was surveyed on August 14, 2019, and the average watersurface elevation of the river in the survey area, determined by the RTK GPS tide solution, was $728.2 \mathrm{ft}$ (table 5; fig. 38). Streamflow on the Missouri River was about $142,000 \mathrm{ft}^{3} / \mathrm{s}$ during the survey (table 5).

The survey area was about 1,640 ft long and averaged about $875 \mathrm{ft}$ wide, extending from bank to bank in the main channel (fig. 38). The upstream end of the survey area was about $700 \mathrm{ft}$ upstream from the centerline of structure A7650 at the main channel pylon (fig. 38). The channel-bed elevations ranged from about 690 to $714 \mathrm{ft}$ for most of the surveyed area (5th to 95 th percentile range of the bathymetric data; table 5; fig. 39), except near the pylon and downstream from the spur dike on the downstream left (north) bank (fig. 38). The shallow thalweg in the channel at upstream structure A4060 diminished, such that there was no definitive thalweg along either side of the channel upstream from structure A7650 (fig. 38). Numerous small to medium dunes and ripples were present throughout the channel, and downstream translation of the smaller dunes and ripples between survey passes were more pronounced at this site than at the upstream sites (fig. 38). Downstream from the spur dike on the left (north) side of the downstream reach, the minimum channel-bed elevations of $671 \mathrm{ft}$ was observed (fig. 38; table 5). As in previous surveys at this site (Huizinga, 2012, 2016), stone revetment was present on the right (south) bank throughout the reach, including the apparent slumped area near the downstream end of the reach observed in the previous survey (fig. 38).

As in previous surveys at this site (Huizinga, 2012, 2016), the main channel pylon seemed to be surrounded by a mound of rock riprap as a scour countermeasure, with a local minimum channel-bed elevation of about $677 \mathrm{ft}$ near the downstream left (north) corner (fig. 38; table 6). The top of the riprap around the upstream face of the pylon was at an elevation of about $697 \mathrm{ft}$, which is slightly below the elevation of the bottom of the pylon seal course of $699.50 \mathrm{ft}$ (table 6); the top of the riprap along the sides of the pylon is lower than at the upstream face (figs. 38 and 40). The minimum channel-bed elevation near the pylon was about $22 \mathrm{ft}$ below the elevation of the bottom of the pylon seal course (fig. 38; table 6). Information from bridge plans indicates that the pylon is founded on shafts drilled $32 \mathrm{ft}$ into bedrock, with about $30 \mathrm{ft}$ of bed material between the bottom of the scour hole and bedrock (fig. 40; table 6).

The difference between the survey on August 14, 2019, and the previous nonflood survey on June 3, 2015 (fig. 41), indicates about 79 percent of the joint area of interest had detectable change, which means about 21 percent of the differences in the joint area of interest are equivocal and within the uncertainty. Bed variation from 2015 to 2019 is moderate to substantial in the DoD map, and scour is predominant throughout the reach except small areas along the left (north) side of the channel and in the upstream right (south) part (fig. 41). The average difference between the bathymetric surfaces was $-3.48 \mathrm{ft}$ (table 7), indicating moderate to substantial degradation between the 2015 and 2019 surveys. The net volume of cut in the reach from 2015 to 2019 was about 141,200 $\mathrm{yd}^{3}$, and the net volume of fill was about $8,500 \mathrm{yd}^{3}$, resulting in a net loss of about 132,700 $\mathrm{yd}^{3}$ of sediment between 2015 and 2019. The cross sections from the two surveys along the upstream face of the bridge are similar to each other but have uniform scour of about $5 \mathrm{ft}$ between the pylon and the right (south) bank (fig. 40). The frequency distribution of bed elevations in 2019 was wider than 2015 because of a higher percentage of cells at lower channel-bed elevations (fig. 39). The scour hole near the main channel pylon was smaller and shallower upstream from the pylon but deeper downstream as evidenced by the areas of deposition and scour near the pylon in the DoD map (fig. 41). The rock riprap around the pylon base also indicated only minor differences, or differences within the uncertainty (fig. 41). As with previous DoD maps, substantial deposition or scour apparent at the faces of the pylon footing results from minor horizontal positional variances between the surveys (see "Uncertainty Estimation" section). The stone revetment on the right (south) bank showed signs of very minor localized deposition and scour, primarily downstream from the bridge (fig. 41); most of the differences on the right (south) bank were within the uncertainties of the data.

The difference between the survey on August 14, 2019, and the previous flood survey on July 17, 2011 (fig. 42), indicates about 74 percent of the joint area of interest had detectable change, which means about 26 percent of the differences in the joint area of interest are equivocal and within the uncertainty. Bed variation appeared about equal between scour and deposition from 2011 to 2019 in the DoD map, with substantial scour downstream from the spur dike on the downstream left (north) side and in the upstream left (north) and downstream right (south) parts of the reach, and moderate to substantial deposition near the pylon and location of the old pier of structure L0734 (fig. 42). The average difference between the bathymetric surfaces was $-1.29 \mathrm{ft}$ (table 7 ), indicating minor to moderate degradation between the 2011 and 2019 surveys. The net volume of cut in the reach from 2011 to 2019 was about $86,900 \mathrm{yd}^{3}$, and the net volume of fill was about $39,600 \mathrm{yd}^{3}$, resulting in a net loss of about $47,300 \mathrm{yd}^{3}$ of sediment between 2011 and 2019. The cross sections from the two surveys along the upstream face of the bridge show the substantial variation in the surveyed sections (fig. 40). However, the frequency distribution of bed elevations in 2019 was remarkably similar in shape to 2011 (fig. 39). The scour hole near the main channel pylon was smaller and shallower upstream from the pylon, as evidenced by the area of deposition near the pylon in the DoD map (fig. 42). The rock riprap around the pylon base indicated moderate differences (fig. 42), and the cross-section along the upstream bridge face shows the riprap has lowered by as much as $7 \mathrm{ft}$ since 2011 (fig. 40). 


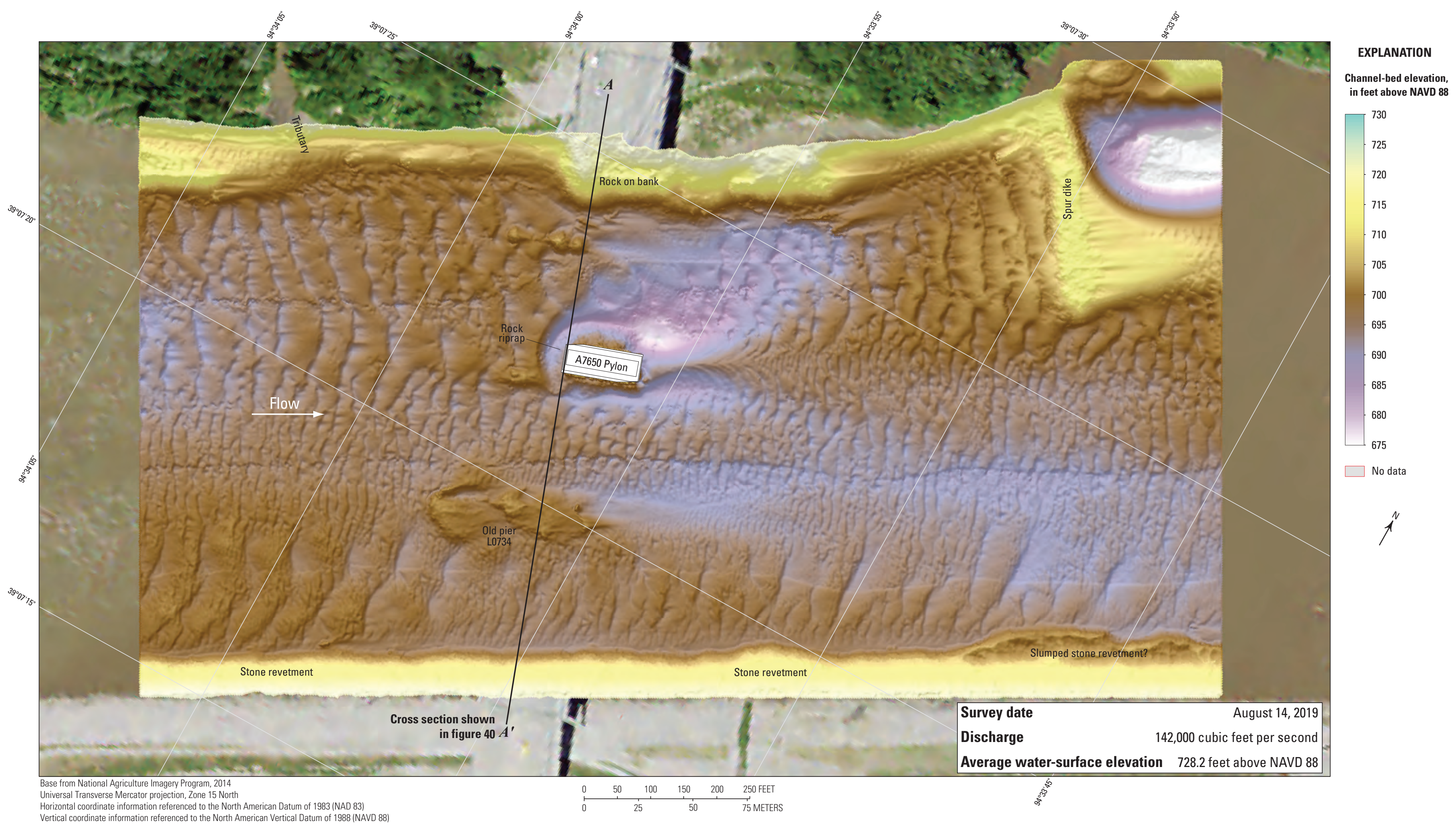

Figure 38. Bathymetric survey of the Missouri River channel near structure A7650 on Interstate 35 in Kansas City, Missouri, on August 14, 2019. 


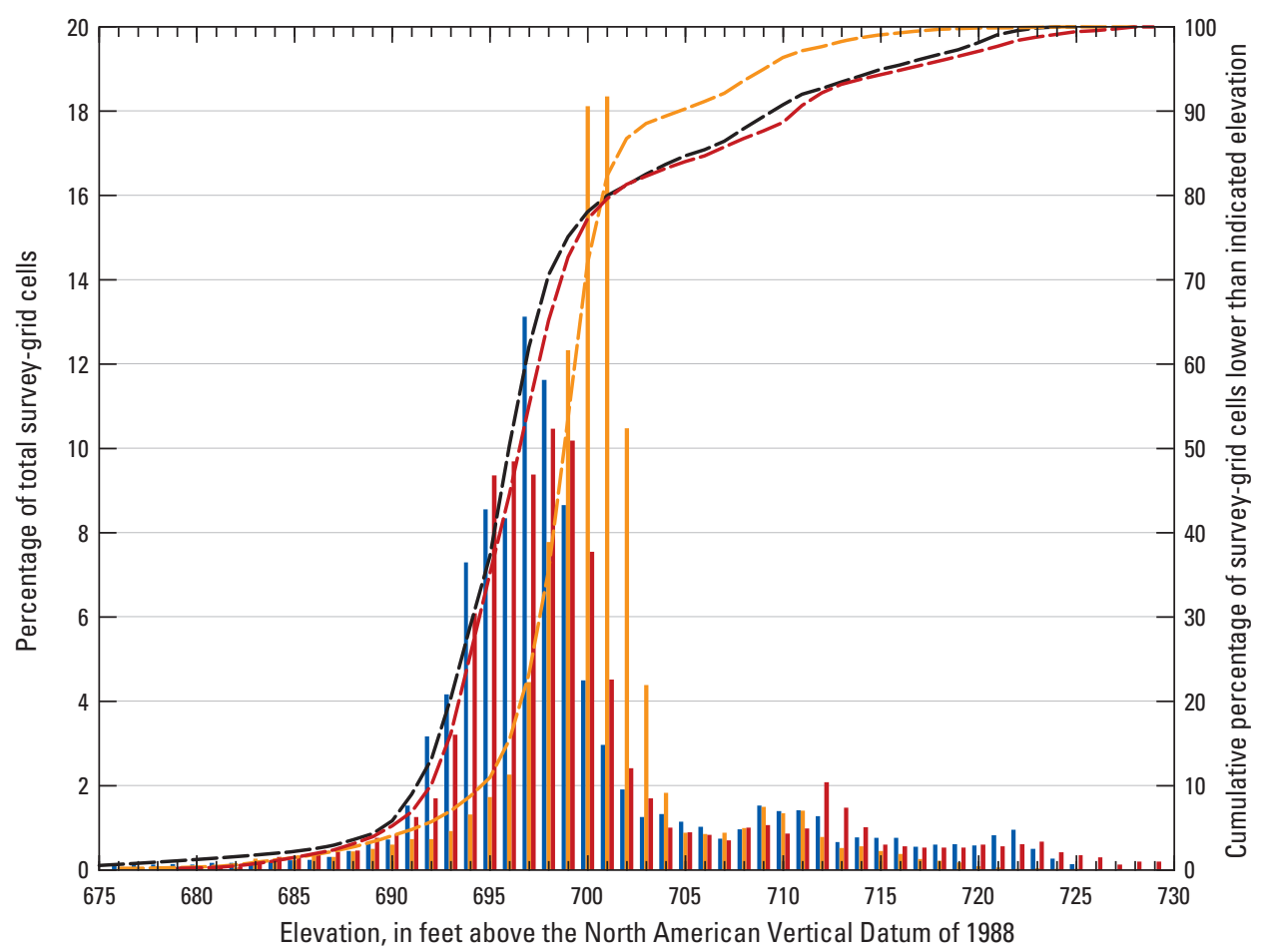

\section{EXPLANATION \\ $\left[\mathrm{ft}^{3} / \mathrm{s}\right.$, cubic foot per second]}

\section{Frequency distribution}

2019 survey data; $142,000 \mathrm{ft}^{3} / \mathrm{s}$

2015 survey data; $97,100 \mathrm{ft}^{3} / \mathrm{s}$

2011 survey data; $217,000 \mathrm{ft}^{3} / \mathrm{s}$ Cumulative percentage

- 2019 survey data; $142,000 \mathrm{ft}^{3} / \mathrm{s}$

- 2015 survey data; $97,100 \mathrm{ft}^{3} / \mathrm{s}$

_- 2011 survey data; $217,000 \mathrm{ft}^{3} / \mathrm{s}$

Figure 39. Frequency distribution of bed elevations for bathymetric survey-grid cells in 1-foot elevation bins on the Missouri River near structure A7650 on Interstate 35 in Kansas City, Missouri, on August 14, 2019, compared to previous surveys in 2011 and 2015 (Huizinga, 2012, 2016, respectively).

As with previous DoD maps, substantial deposition or scour apparent at the faces of the pylon footing results from minor horizontal positional variances between the surveys (see "Uncertainty Estimation" section). The stone revetment on the right (south) bank showed signs of nearly uniform minor scour in the DoD map (fig. 42).

The vertically averaged velocity vectors indicate mostly uniform flow throughout most of the reach, with velocities ranging from about 2 to $8 \mathrm{ft} / \mathrm{s}$ (fig. 43). Exceptions to uniform conditions include flow reversal along the left (north) bank near the upstream tributary and in the pool downstream from the spur dike (fig. 43). Substantial turbulence also was observed downstream from the main channel pylon (fig. 43), likely as a result of the pylon being skewed to flow. The velocities do not seem to be higher near the bulge in the left bank at the bridge.

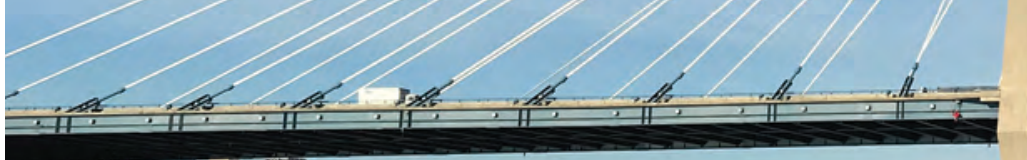




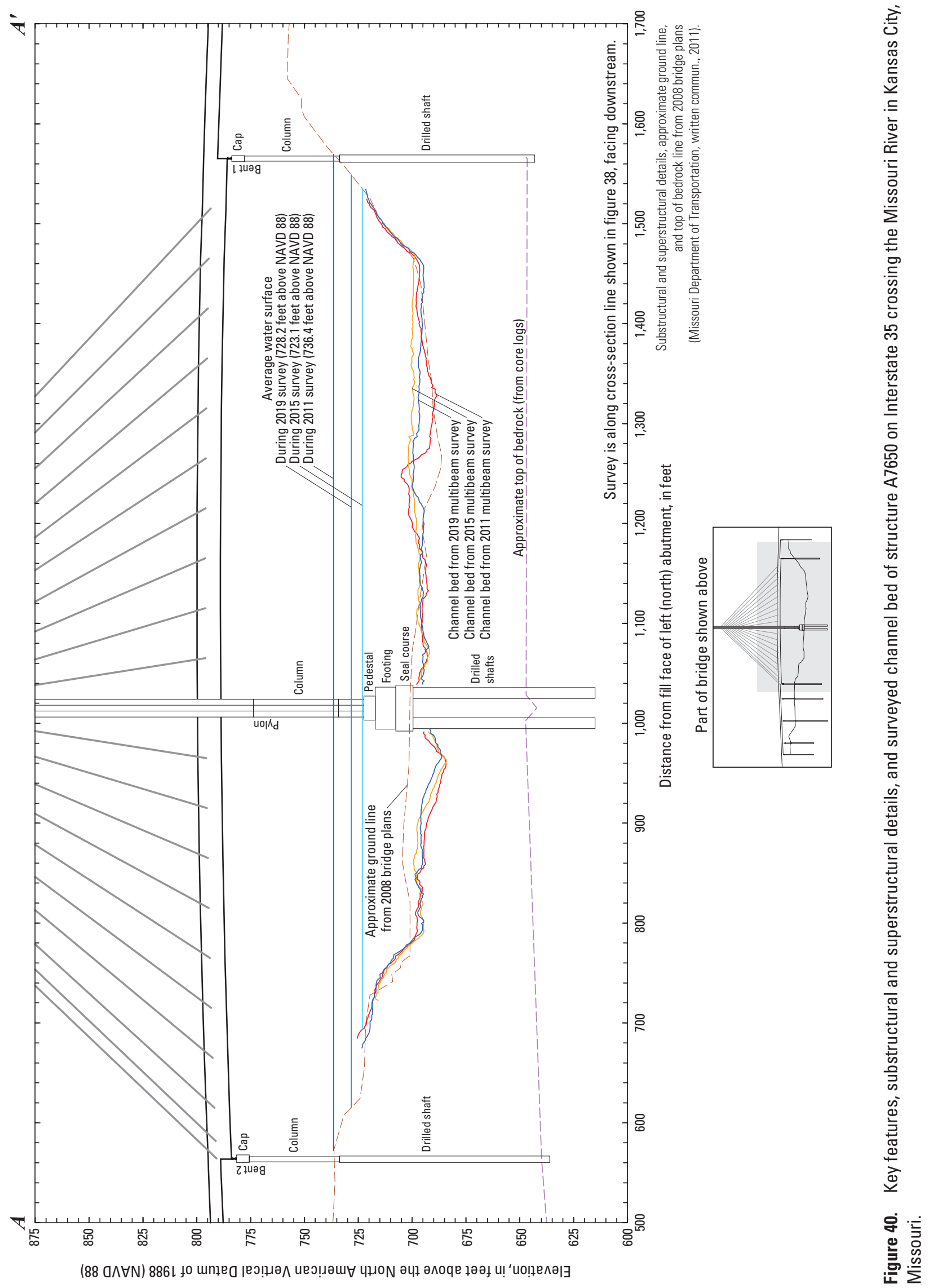




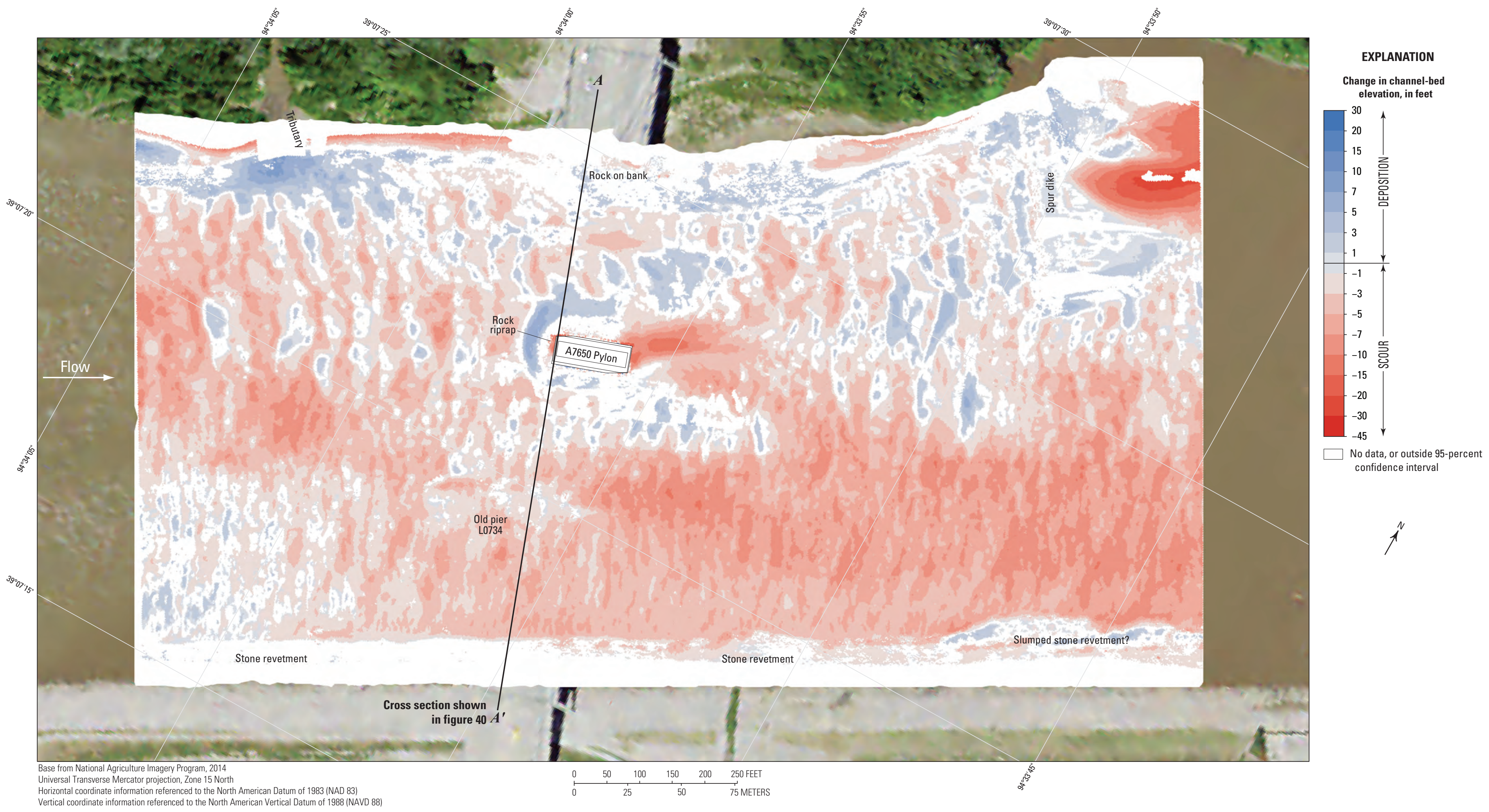

Figure 41. Difference between surfaces created from bathymetric surveys of the Missouri River channel near structure A7650 on Interstate 35 in Kansas City, Missouri, on August 14, 2019 , and June 3, 2015. 


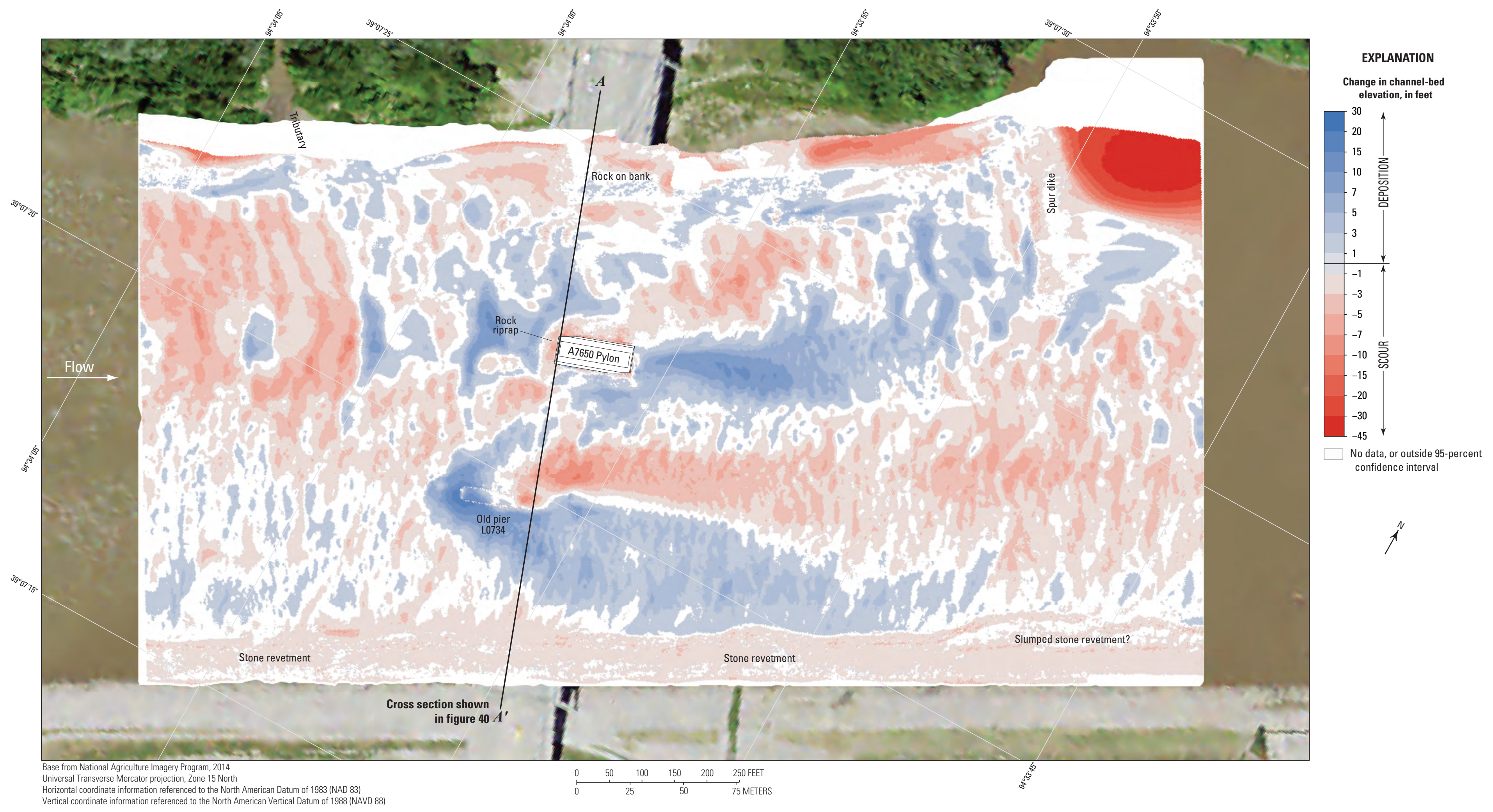

Figure 42. Difference between surfaces created from bathymetric surveys of the Missouri River channel near structure A7650 on Interstate 35 in Kansas City, Missouri, on August 14, 2019, and July 17, 2011. 


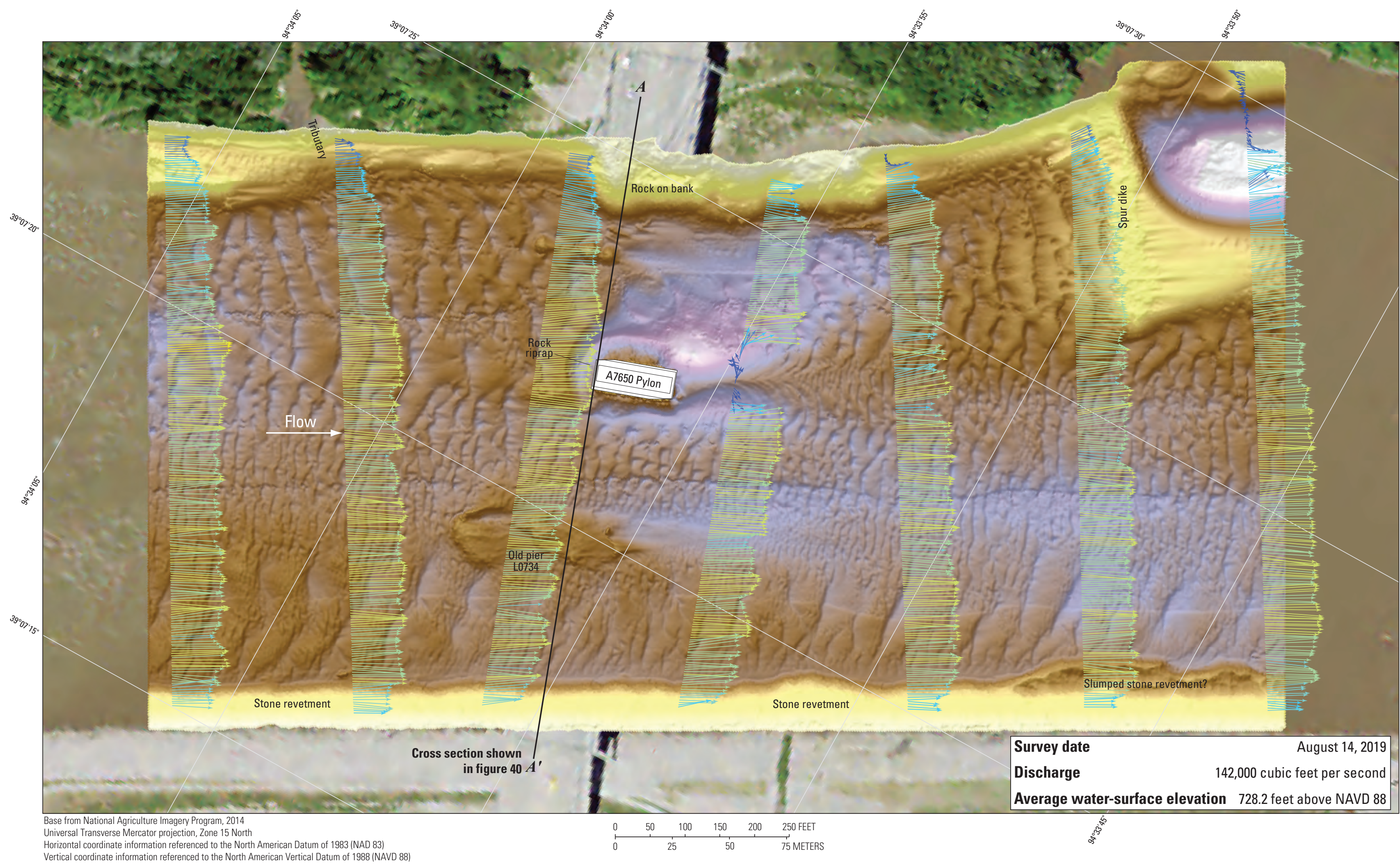

EXPLANATION Channel-bed elevation,
in feet above NAVD 88 $\square 730$ 


\section{Structure A5817 on State Highway 269}

Structure A5817 (site 11; table 1) on State Highway 269 crosses the Missouri River at RM 362.3, northeast of downtown Kansas City, Mo. (fig. 1). The site was surveyed on August 14, 2019, and the average water-surface elevation of the river in the survey area, determined by the RTK GPS tide solution, was $726.5 \mathrm{ft}$ (table 5; fig. 44). Streamflow on the Missouri River was about 142,000 $\mathrm{ft}^{3} / \mathrm{s}$ during the survey (table 5).

The survey area was about 1,640 ft long and averaged about $995 \mathrm{ft}$ wide, extending from bank to bank in the main channel (fig. 44). Piers 2 and 3 were in the water and away from the banks, and the upstream end of the survey area was about $670 \mathrm{ft}$ upstream from the centerline of structure A5817 at pier 2 (fig. 44). The channel-bed elevations ranged from about 691 to $712 \mathrm{ft}$ for most of the surveyed area (5th to 95th percentile range of the bathymetric data; table 5; fig. 45). A moderately deep thalweg along the left (north) bank throughout the surveyed area contained evidence of bedrock exposure and was about 12 to $14 \mathrm{ft}$ deeper than the channel bed in the middle of the channel (fig. 44). Numerous medium dune features were observed in the channel thalweg, and numerous medium to small dunes and ripples were present throughout the rest of the channel, decreasing in size towards the right (south) bank (fig. 44). As in previous surveys at this site (Huizinga, 2010, 2012, 2016), stone revetment and bedrock outcrops were present on the left (north) bank throughout the reach (fig. 44).

A scour hole near main channel pier 2 (fig. 44) had a minimum channel-bed elevation of about $687 \mathrm{ft}$ (table 6), which was about level with the elevation of the bottom of the pier seal course of $687.26 \mathrm{ft}$ (fig. 46; table 6). The top of the pier footing was evident during the survey (fig. 44). The minor scour hole near pier 3 was difficult to discern from nearby small dunes and ripples (fig. 44). Information from bridge plans indicates that piers 2 and 3 of structure A5817 are founded on shafts drilled $20 \mathrm{ft}$ into bedrock, with about $10 \mathrm{ft}$ of bed material between the bottom of the scour hole and bedrock at pier 2 and about $45 \mathrm{ft}$ of material at pier 3 (fig. 46; table 6).

The difference between the survey on August 14, 2019, and the previous nonflood survey on June 3, 2015 (fig. 47), indicates about 89 percent of the joint area of interest had detectable change, which means about 11 percent of the differences in the joint area of interest are equivocal and within the uncertainty. There is moderate to substantial bed variation from 2015 to
2019 in the DoD map, with scour predominant throughout the middle of the reach, and deposition on both banks (fig. 47). The average difference between the bathymetric surfaces was $-1.44 \mathrm{ft}$ (table 7 ), indicating minor to moderate degradation between the 2015 and 2019 surveys. The net volume of cut in the reach from 2015 to 2019 was about $114,200 \mathrm{yd}^{3}$, and the net volume of fill was about $40,800 \mathrm{yd}^{3}$, resulting in a net loss of about 73, $400 \mathrm{yd}^{3}$ of sediment between 2015 and 2019. The cross sections from the two surveys along the upstream face of the bridge are similar to each other but with uniform scour of 5 to $10 \mathrm{ft}$ between the left (north) bank and pier 3 (fig. 46). The frequency distribution of bed elevations in 2019 was wider than 2015 because a higher percentage of cells were at lower and higher channel-bed elevations (fig. 45). The scour hole near the main channel pier 2 was deeper and wider than in 2015, as evidenced by the area of scour near that pier in the DoD map (fig. 47). Alternatively, the change from 2015 to 2019 near main channel pier 3 was equivocal to the uncertainty on the left side of the footing, and there was deposition along the right side (fig. 47). The bedrock outcrops and stone revetment on the left (north) bank showed signs of localized deposition throughout the reach between 2015 and 2019, which is somewhat unexpected (fig. 47); however, the differences on the tops of some of the outcrops were within the uncertainties of the data, which implies there may be a horizontal offset to the 2019 data on the bank that is creating the appearance of deposition.

The difference between the survey on August 14, 2019, and the previous flood survey on July 18, 2011 (fig. 48), indicates about 89 percent of the joint area of interest had detectable change, which means about 11 percent of the differences in the joint area of interest are equivocal and within the uncertainty. Substantial bed variation was apparent from 2011 to 2019 in the DoD map, with substantial scour throughout the reach except along the left (north) bank and in the troughs of substantial dunes present in the 2011 survey (Huizinga, 2012, fig. 48). The average difference between the bathymetric surfaces was $-4.76 \mathrm{ft}$ (table 7), indicating substantial degradation between the 2011 and 2019 surveys. The net volume of cut in the reach from 2011 to 2019 was about 268,900 $\mathrm{yd}^{3}$, and the net volume of fill was about $20,000 \mathrm{yd}^{3}$, resulting in a net loss of about $248,900 \mathrm{yd}^{3}$ of sediment in the reach between 2011 and 2019. The cross sections from the two surveys along the upstream face of the bridge show the substantial difference in the surveyed sections (fig. 46). The frequency distribution of bed
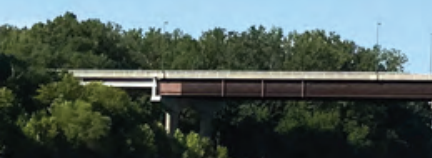


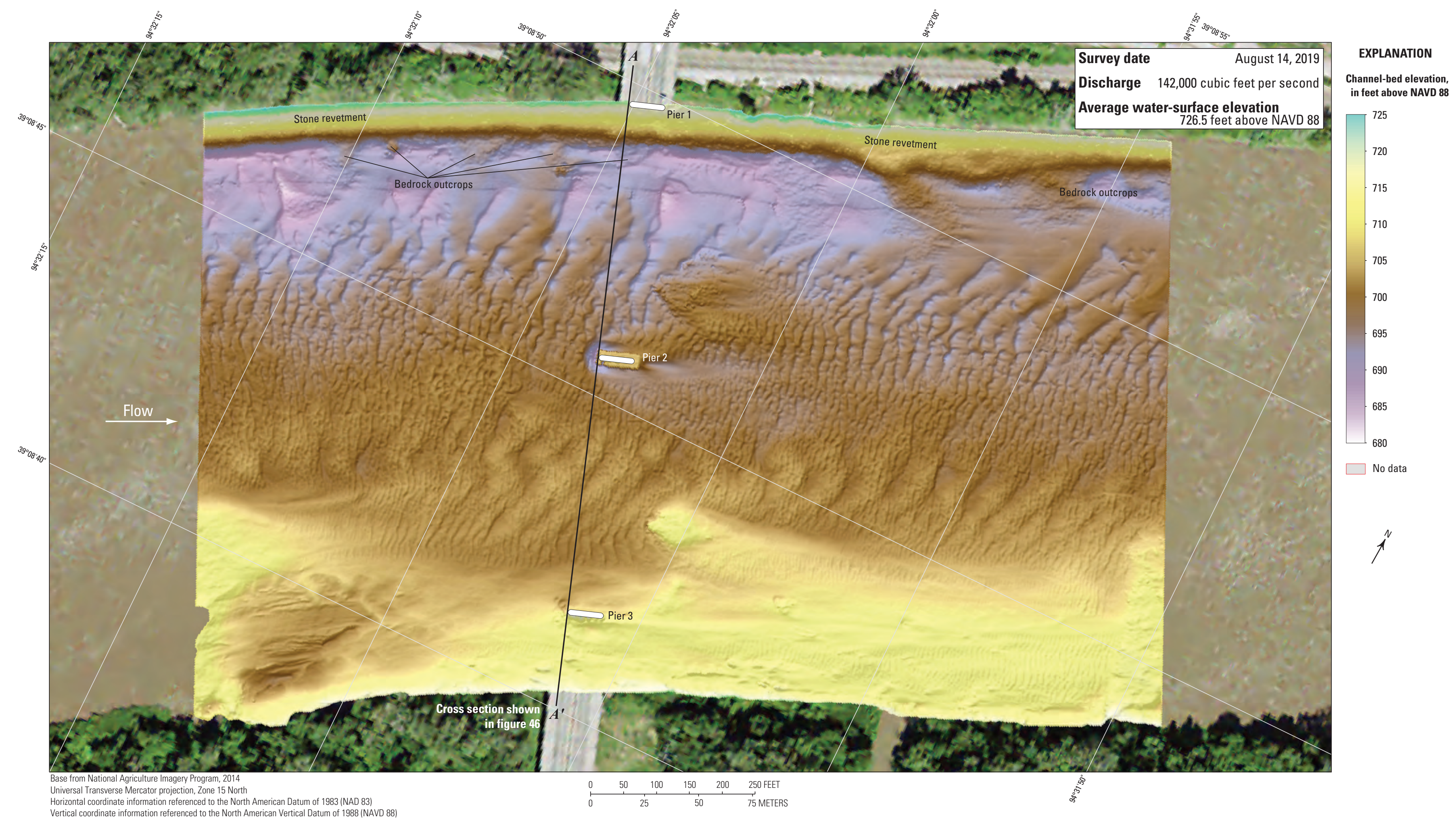

Figure 44. Bathymetric survey of the Missouri River channel near structure A5817 on State Highway 269 in Kansas City, Missouri, on August 14, 2019. 

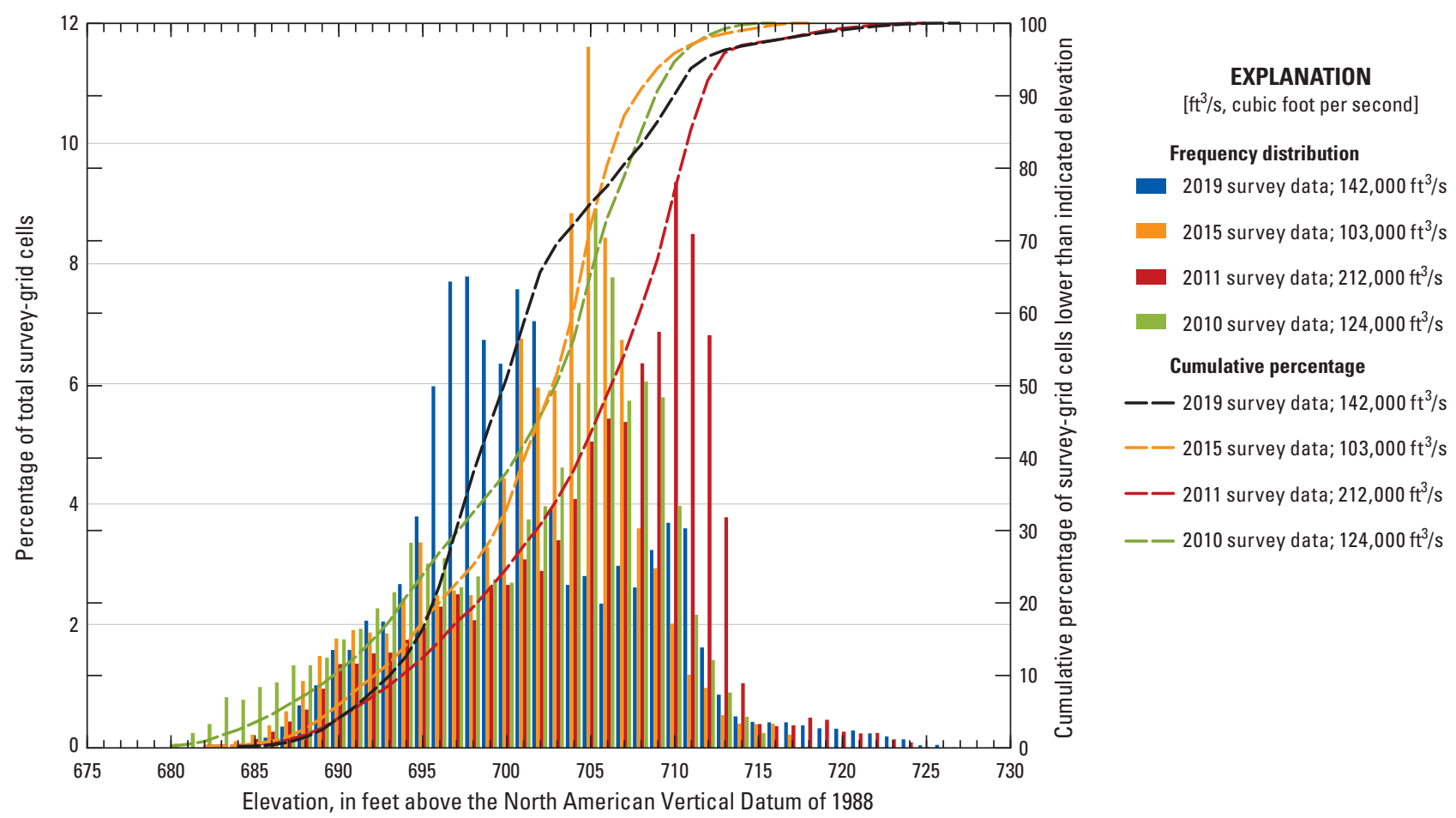

Figure 45. Frequency distribution of bed elevations for bathymetric survey-grid cells in 1-foot elevation bins on the Missouri River near structure A5817 on State Highway 269 in Kansas City, Missouri, on August 14, 2019, compared to previous surveys in 2010, 2011, and 2015 (Huizinga, 2010, 2012, 2016, respectively).

elevations in 2019 also was substantially different from 2011 (fig. 45). The DoD map shows the substantial scour throughout the reach, so the scour hole near main channel pier 2 is indistinguishable from the overall change between 2011 and 2019 (fig. 48). As with the DoD map for 2015 to 2019 (fig. 47), the bedrock outcrops and stone revetment on the left (north) bank showed signs of localized deposition throughout the reach between 2011 and 2019, which is somewhat unexpected (fig. 48); however, the differences on the tops of the outcrops were again within the uncertainties of the data, which implies there may be a horizontal offset to the 2019 data on the bank that is creating the appearance of deposition.

The difference between the survey on August 14, 2019, and the earliest nonflood survey on March 17, 2010 (fig. 49), indicates about 80 percent of the joint area of interest had detectable change, which means about 20 percent of the differences in the joint area of interest are equivocal and within the uncertainty. Bed variation seemed nearly equal between scour and deposition from 2010 to 2019 in the DoD map, deposition was predominant along the thalweg on the left (north) side of the channel, and scour was predominant along the middle and right (south) side (fig. 49). However, the average difference between the bathymetric surfaces was $-1.38 \mathrm{ft}$ (table 7), indicating minor to moderate channel degradation between the 2010 and 2019 surveys. The net volume of cut in the reach from 2010 to 2019 was about $111,500 \mathrm{yd}^{3}$, and the net volume of fill was about $50,100 \mathrm{yd}^{3}$, resulting in a net loss of about $61,400 \mathrm{yd}^{3}$ of sediment between 2010 and 2019. The cross sections from the two surveys along the upstream face of the bridge are similar to each other but had deposition of 5 to $10 \mathrm{ft}$ between the left (north) bank and pier 2 and scour of 5 to $10 \mathrm{ft}$ between piers 2 and 3 (fig. 46). The frequency distribution of bed elevations in 2019 was different from 2010 because a higher percentage of cells was at lower channel-bed elevations (fig. 45); however, the surveyed area was substantially wider in 2019 than in 2010 and extended higher on the channel banks, particularly on the right (south) side (fig. 49). The bedrock outcrops and stone revetment on the left (north) bank showed signs of minor, localized deposition, particularly in the upstream reach in the DoD map (fig. 49); however, much of the differences on the left (north) side of the channel — and particularly the tops of the outcropswere again within the uncertainties of the data, as would be expected. As with previous DoD maps, substantial deposition or scour is apparent at the faces of the pier footings resulting from minor horizontal positional variances between the surveys (see "Uncertainty Estimation" section).

The vertically averaged velocity vectors indicate mostly uniform flow throughout the reach, ranging from about $3 \mathrm{ft} / \mathrm{s}$ along the inside of the bend on the right (south) bank to $9 \mathrm{ft} / \mathrm{s}$ in the thalweg along the left (north) bank (fig. 50). Exceptions to uniform flow include flows angled to the left (north) in the upstream part of the reach because of the bend in the channel (fig. 50). Moderate turbulence also was observed along the thalweg near the bedrock outcrops, along the inside of the bend along the right (south) bank, and downstream from pier 3 (fig. 50). 


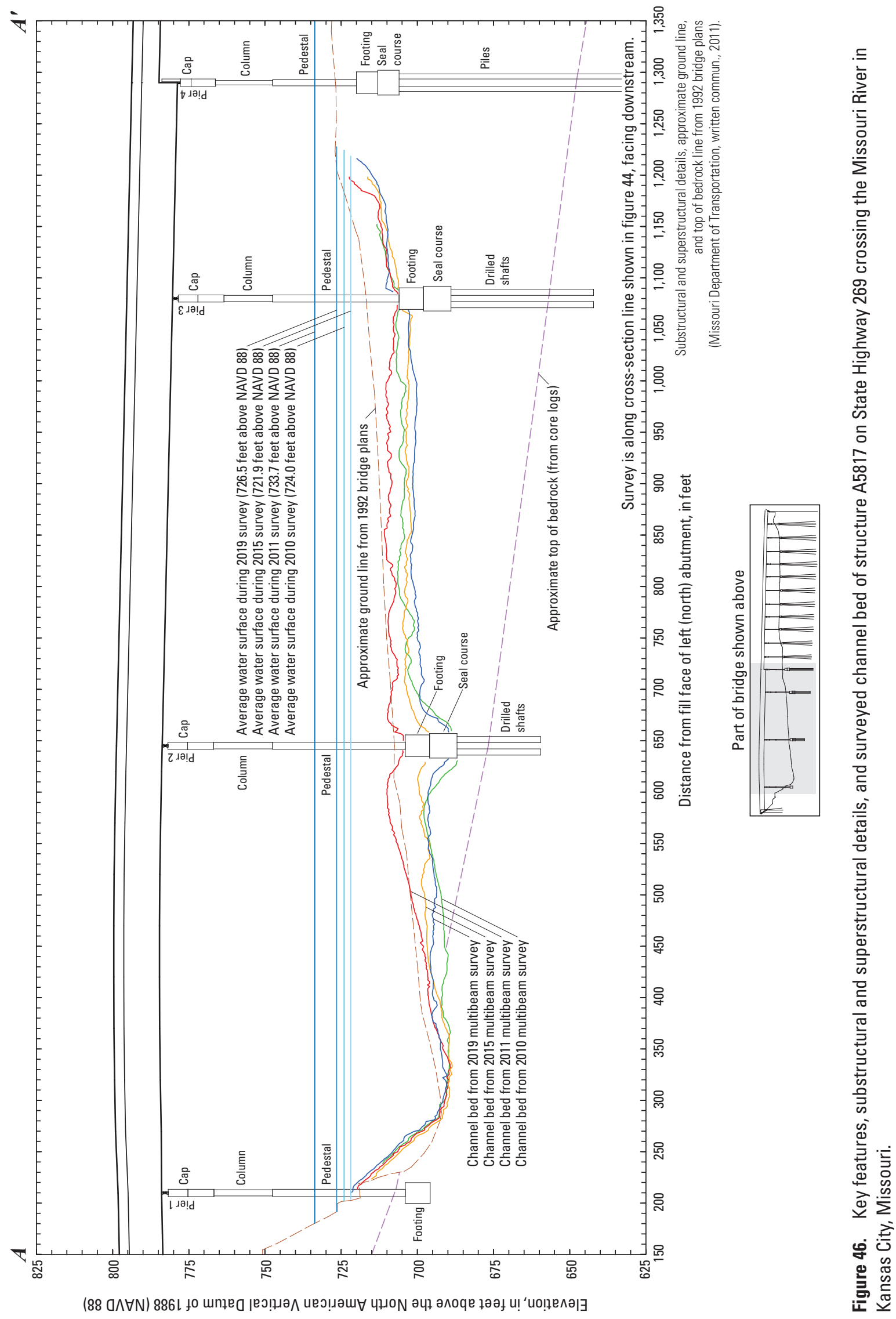




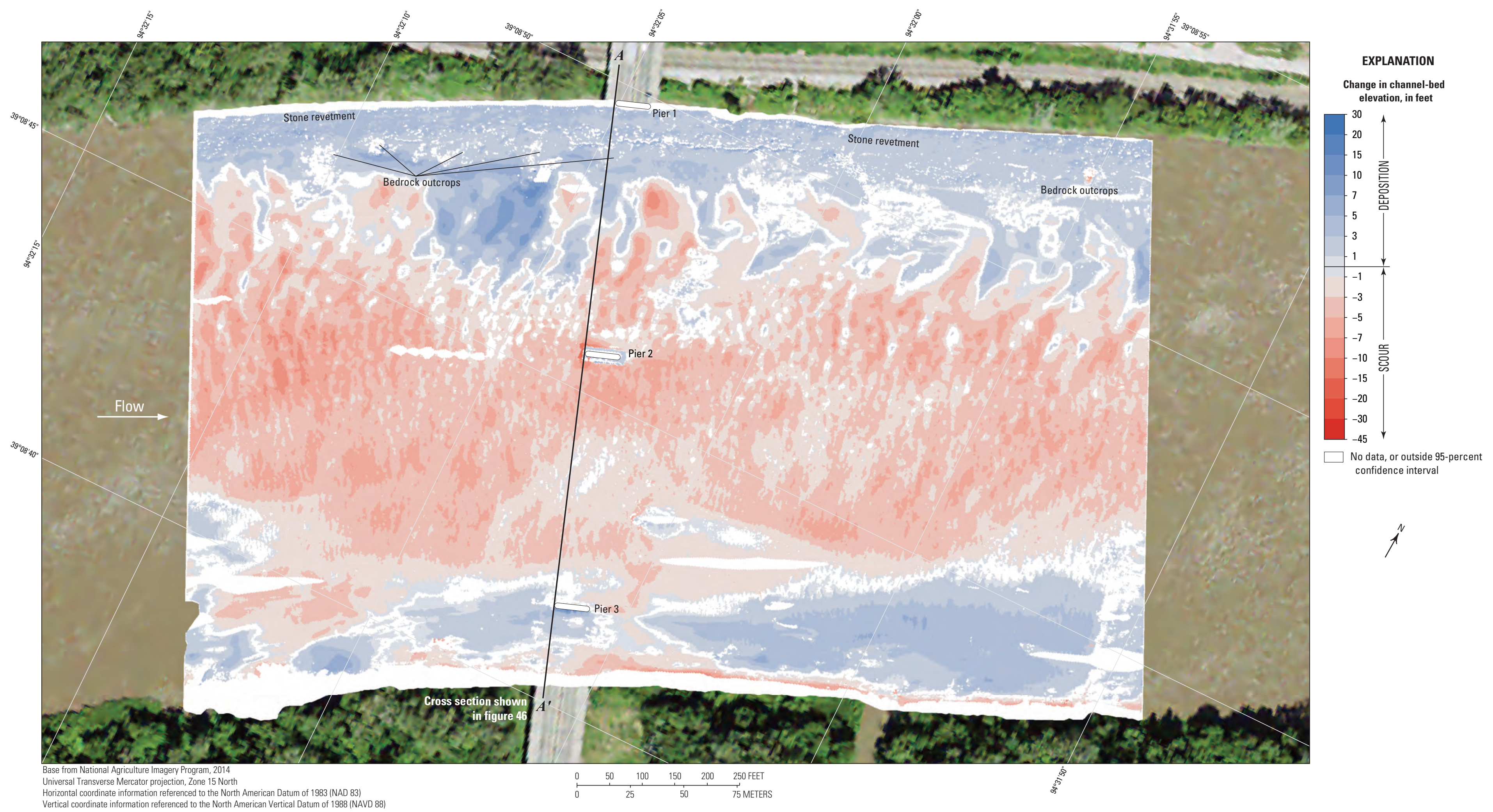

Figure 47. Difference between surfaces created from bathymetric surveys of the Missouri River channel near structure A5817 on State Highway 269 in Kansas City, Missouri, on August 14, 2019 , and June 3, 2015. 


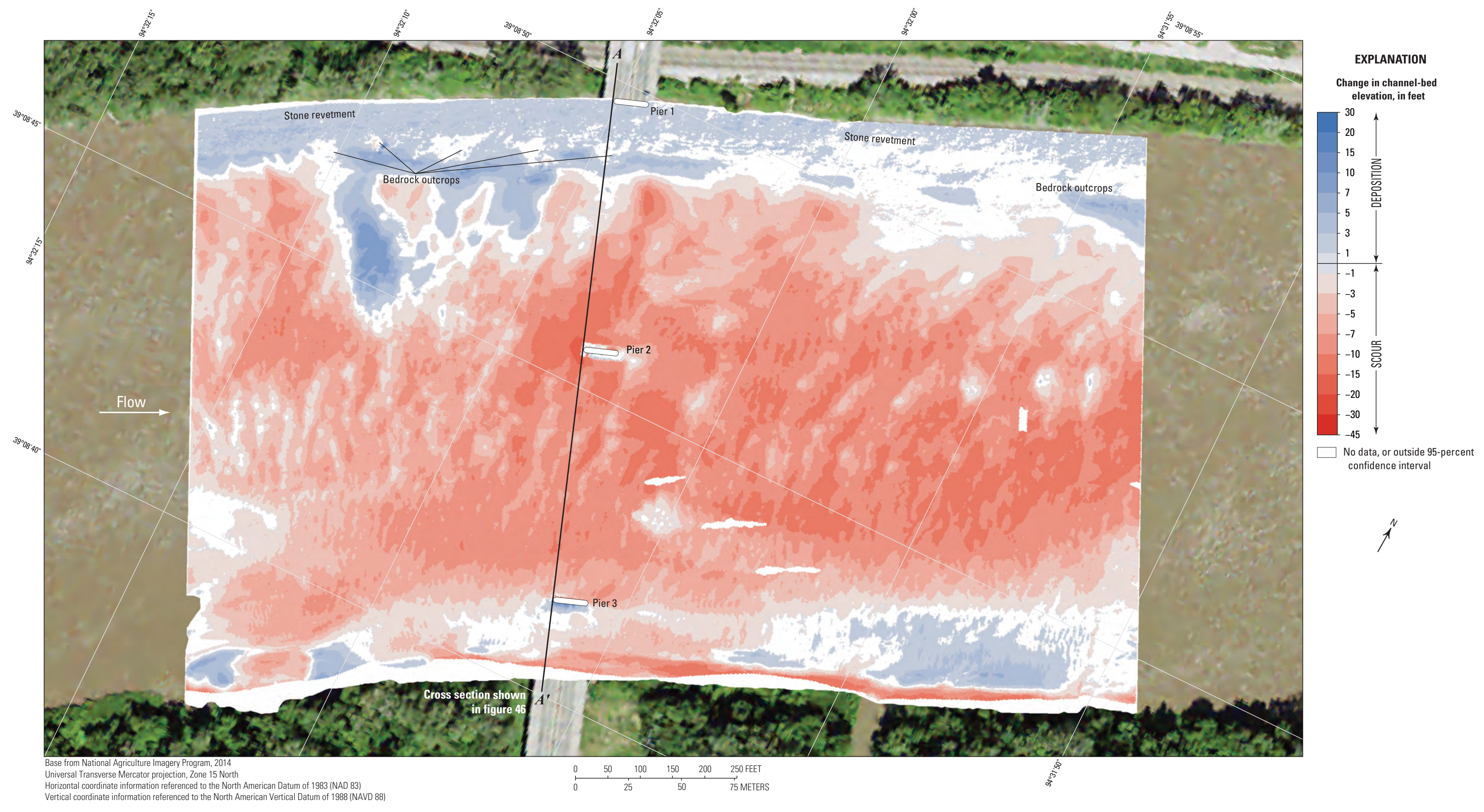

Figure 48. Difference between surfaces created from bathymetric surveys of the Missouri River channel near structure A5817 on State Highway 269 in Kansas City, Missouri, on August 14, 2019 , and July 18, 2011. 


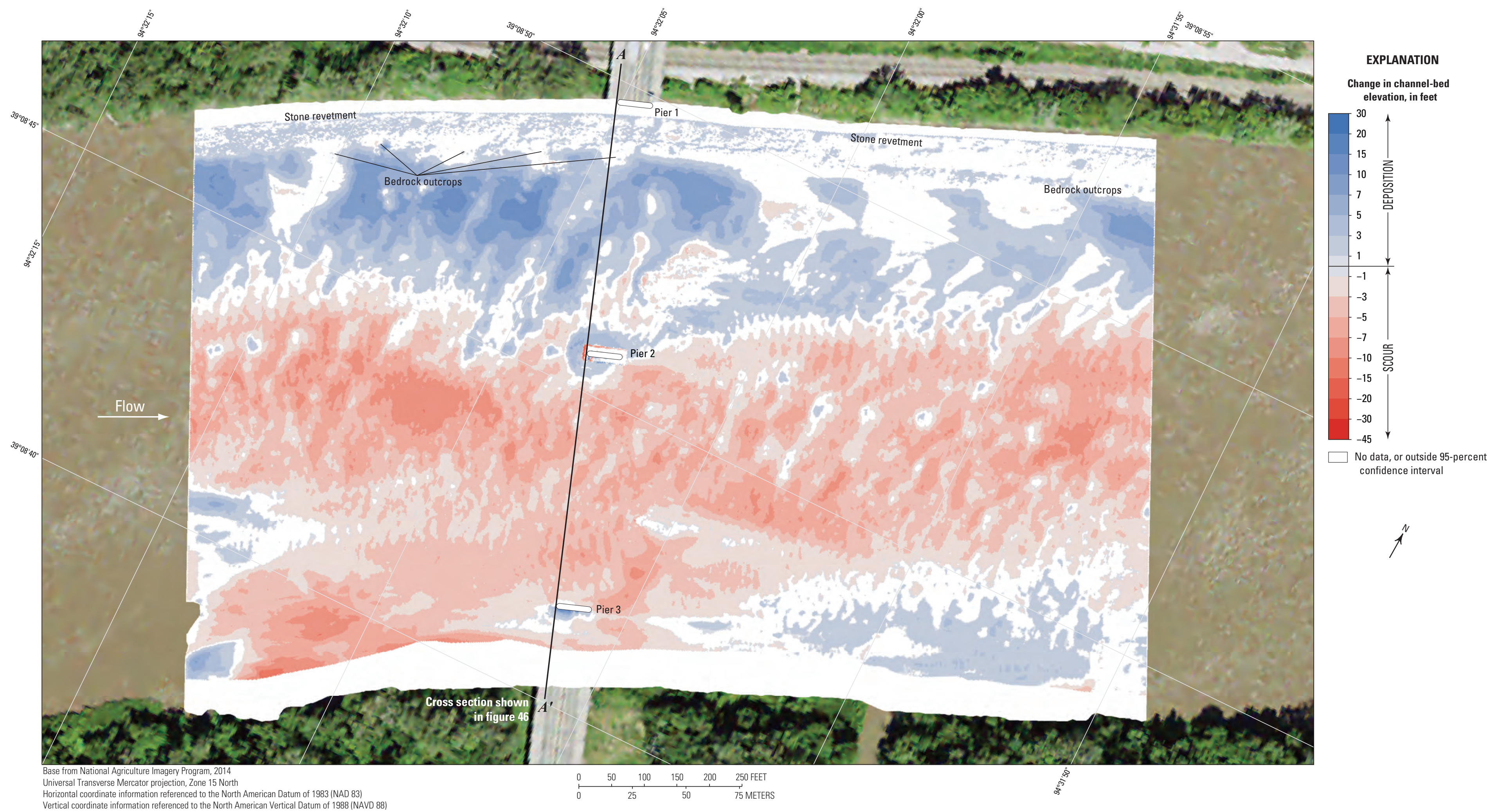

Figure 49. Difference between surfaces created from bathymetric surveys of the Missouri River channel near structure A5817 on State Highway 269 in Kansas City, Missouri, on August 14, 2019 , and March 17, 2010. 


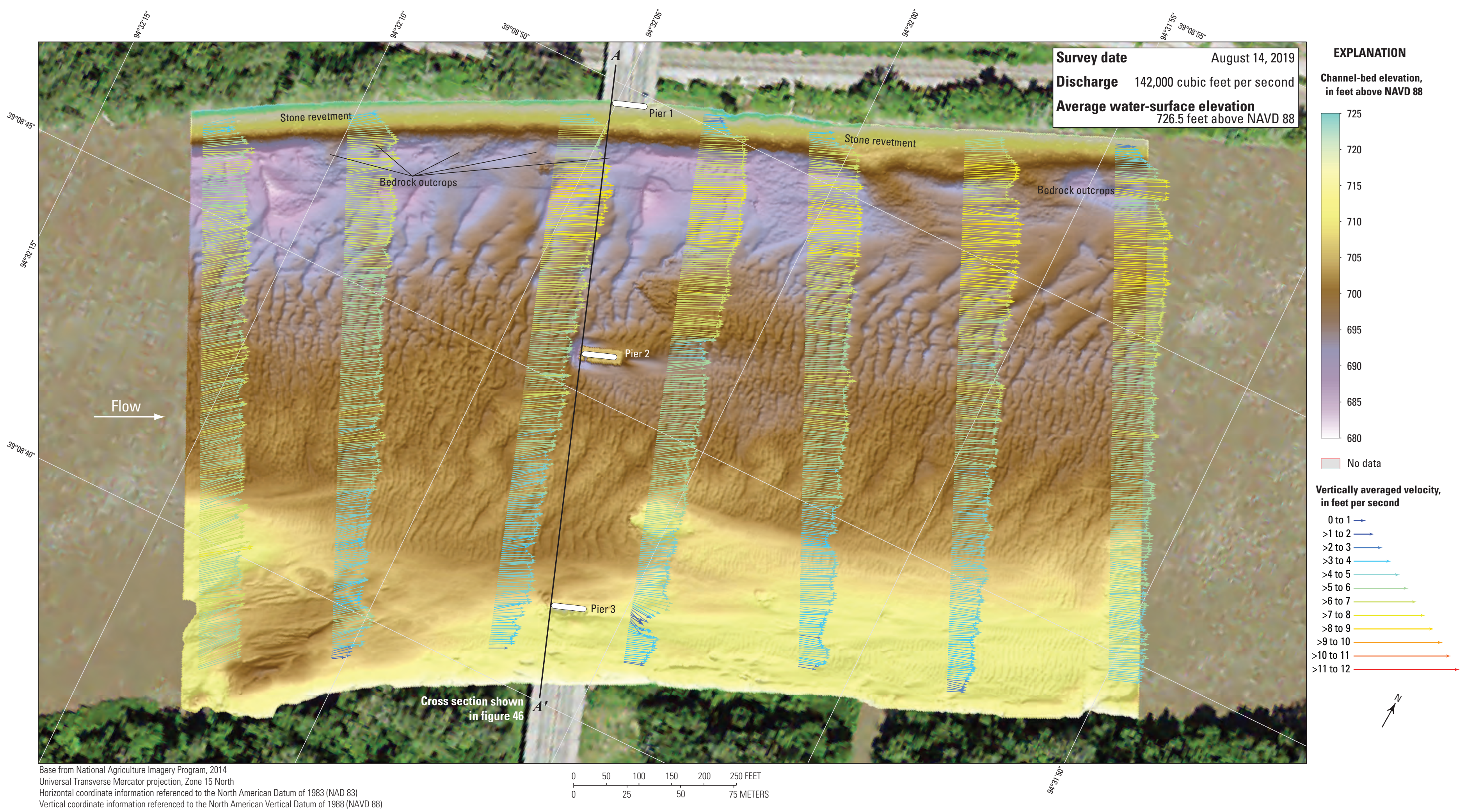

Figure 50. Bathymetry and vertically averaged velocities of the Missouri River channel near structure A5817 on State Highway 269 in Kansas City, Missouri, on August 14, 2019. 


\section{Structure A0767 on Interstate 435}

Structure A0767 (site 12; table 1) on Interstate 435 crosses the Missouri River at RM 360.3, on the northeastern side Kansas City, Mo. (fig. 1). The site was surveyed on August 14, 2019, and the average water-surface elevation of the river in the survey area, determined by the RTK GPS tide solution, was $725.1 \mathrm{ft}$ (table 5; fig. 51). Streamflow on the Missouri River was about 139,000 $\mathrm{ft}^{3} / \mathrm{s}$ during the survey (table 5).

The survey area was about 1,640 ft long and averaged about $930 \mathrm{ft}$ wide, extending from bank to bank in the main channel (fig. 51). Piers 7 and 8 were in the water and away from the banks at structure A0767; however, as in previous surveys (Huizinga, 2010, 2012, 2016), pier 8 was immediately downstream from a spur dike and the upstream end of the pier was surrounded by a persistent substantial debris raft; however, bathymetric data could be obtained around the downstream end (fig. 51). A substantial and persistent sand bar also was present downstream from pier 8, as in previous surveys (Huizinga, 2010, 2012, 2016; fig. 51). The upstream end of the survey area was about $660 \mathrm{ft}$ upstream from the centerline of structure A0767 at pier 7 (fig. 51). The channelbed elevations ranged from about 682 to $711 \mathrm{ft}$ for most of the surveyed area (5th to 95th percentile range of the bathymetric data; table 5; fig. 52), except downstream from the tip of the spur dike and in the downstream reach near the rock outcrop on the left (north) bank (fig. 51). A shallow but wide thalweg was along the left (north) bank throughout the surveyed area, and became deeper in the downstream direction. The channel was filled with numerous medium dune features along the thalweg along the left (north) side of the channel and numerous small dunes and ripples throughout the rest of the channel, decreasing in size towards the banks (fig. 51). As in previous surveys at this site (Huizinga, 2010, 2012, 2016), stone revetment and bedrock outcrops were present on the left (north) bank throughout the reach (fig. 51).

The scour hole near main channel pier 7 (fig. 51) had a minimum channel-bed elevation of about $678 \mathrm{ft}$ (table 6), which was about $11 \mathrm{ft}$ below the elevation of the bottom of the pier seal course of $689.26 \mathrm{ft}$ (fig. 53; table 6). The undermined seal course are evident in a shaded triangulated irregular network (TIN) image of the right (south) side of pier 7 (fig. 1.8). The upstream end of pier 8 was embedded in the rock spur dike and could not be surveyed because of the persistent substantial debris raft (fig. 51). The top of the footing on the downstream end of the pier was visible (fig. 51), but the minimum channel elevation adjacent to the pier footing was about $694 \mathrm{ft}$, which was about $5 \mathrm{ft}$ higher than the bottom of the seal course elevation of $689.26 \mathrm{ft}$ (table 6). Information from bridge plans indicates that piers 7 and 8 are founded on shafts drilled $20 \mathrm{ft}$ into bedrock, with about $18 \mathrm{ft}$ of bed material between the bottom of the scour hole and bedrock at pier 7 and about $46 \mathrm{ft}$ of material at pier 8 (fig. 53; table 6). A substantial hole was present downstream from the tip of the spur dike, which contained the minimum channel elevation in the surveyed area of $668 \mathrm{ft}$ (fig. 51; table 5); however, this hole was more than $50 \mathrm{ft}$ away from pier 8 , and substantial alluvial material was present between the hole and the pier.

The difference between the survey on August 14, 2019 , and the previous nonflood survey on June 4, 2015 (fig. 54), indicates about 80 percent of the joint area of interest had detectable change, which means about 20 percent of the differences in the joint area of interest are equivocal and within the uncertainty. Bed variation from 2015 to 2019 was moderate to substantial in the DoD map, deposition was predominant in the thalweg on the left (north) side, and scour was predominant throughout the middle and right (south) side of the reach (fig. 54). The average difference between the bathymetric surfaces was $-4.17 \mathrm{ft}$ (table 7), indicating substantial degradation between the 2015 and 2019 surveys. The net volume of cut in the reach from 2015 to 2019 was about $187,700 \mathrm{yd}^{3}$, and the net volume of fill was only about $11,200 \mathrm{yd}^{3}$, resulting in a net loss of about $176,500 \mathrm{yd}^{3}$ of sediment between 2015 and 2019. The cross sections from the two surveys along the upstream face of the bridge indicate the trends from the DoD map, and deposition in the thalweg and scour was as much as $20 \mathrm{ft}$ between pier 7 and the spur dike (fig. 53). The frequency distribution of bed elevations in 2019 appeared similar to 2015 but had a higher percentage of cells at lower channel-bed elevations than 2015 (fig. 52). The scour hole near main channel pier 7 was similar to that in 2015, as evidenced by the area of equivocal data in a horseshoe shape around the upstream end of that pier in the DoD map (fig. 54). However, on the downstream side of piers 7 and 8 , substantial scour had occurred between 2015 and 2019 (fig. 54). The bedrock outcrops and stone revetment on the left (north) bank showed signs of localized scour and deposition throughout the reach between 2015 and 2019 (fig. 54), which was expected because of erroneous positioning during data collection in the 2015 survey (Huizinga, 2016) that created an offset of the data along the upstream left (north) bank between surveys.

The difference between the survey on August 14, 2019, and the previous flood survey on July 18, 2011 (fig. 55), indicates about 82 percent of the joint area of interest had detectable change, which means about 18 percent of the differences in the joint area of interest are equivocal and within the uncertainty. Bed variation from 2015 to 2019 was moderate to substantial in the DoD map, deposition was predominant in the thalweg on the left (north) side and in the troughs of substantial dunes present in the 2011 survey (Huizinga, 2012), and scour was predominant throughout the middle and right (south) side of the reach (fig. 55). The average difference between the bathymetric surfaces was $-2.28 \mathrm{ft}$ (table 7), indicating moderate degradation between the 2011 and 2019 surveys. The net volume of cut in the reach from 2011 to 2019 was about $147,800 \mathrm{yd}^{3}$, and the net volume of fill was about 49,900 $\mathrm{yd}^{3}$, resulting in a net loss of about 97,900 $\mathrm{yd}^{3}$ of sediment in the reach between 2011 and 2019. The cross sections from the two surveys along the upstream face of the 


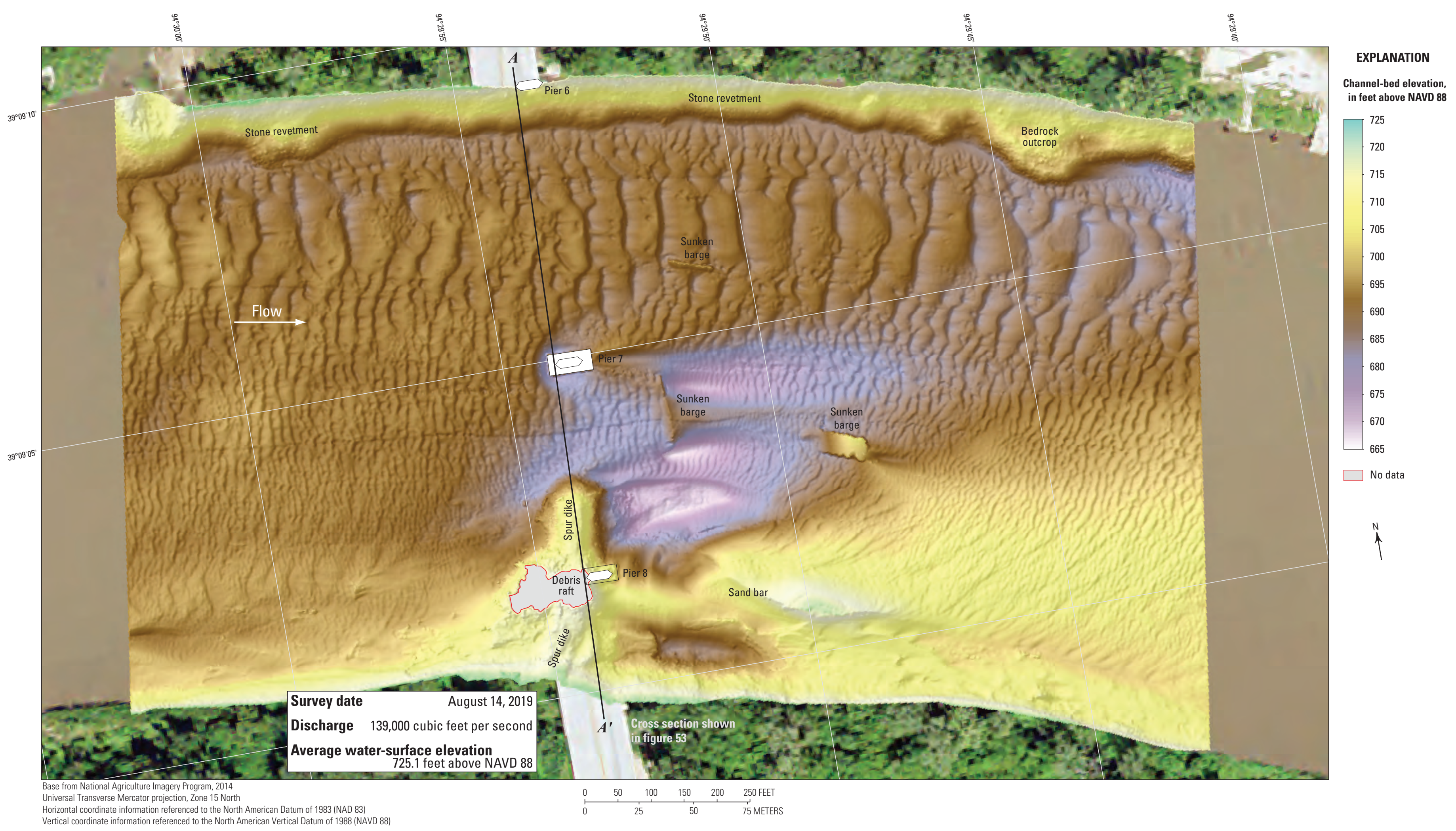

Figure 51. Bathymetric survey of the Missouri River channel near structure A0767 on Interstate 435 in Kansas City, Missouri, on August 14, 2019. 

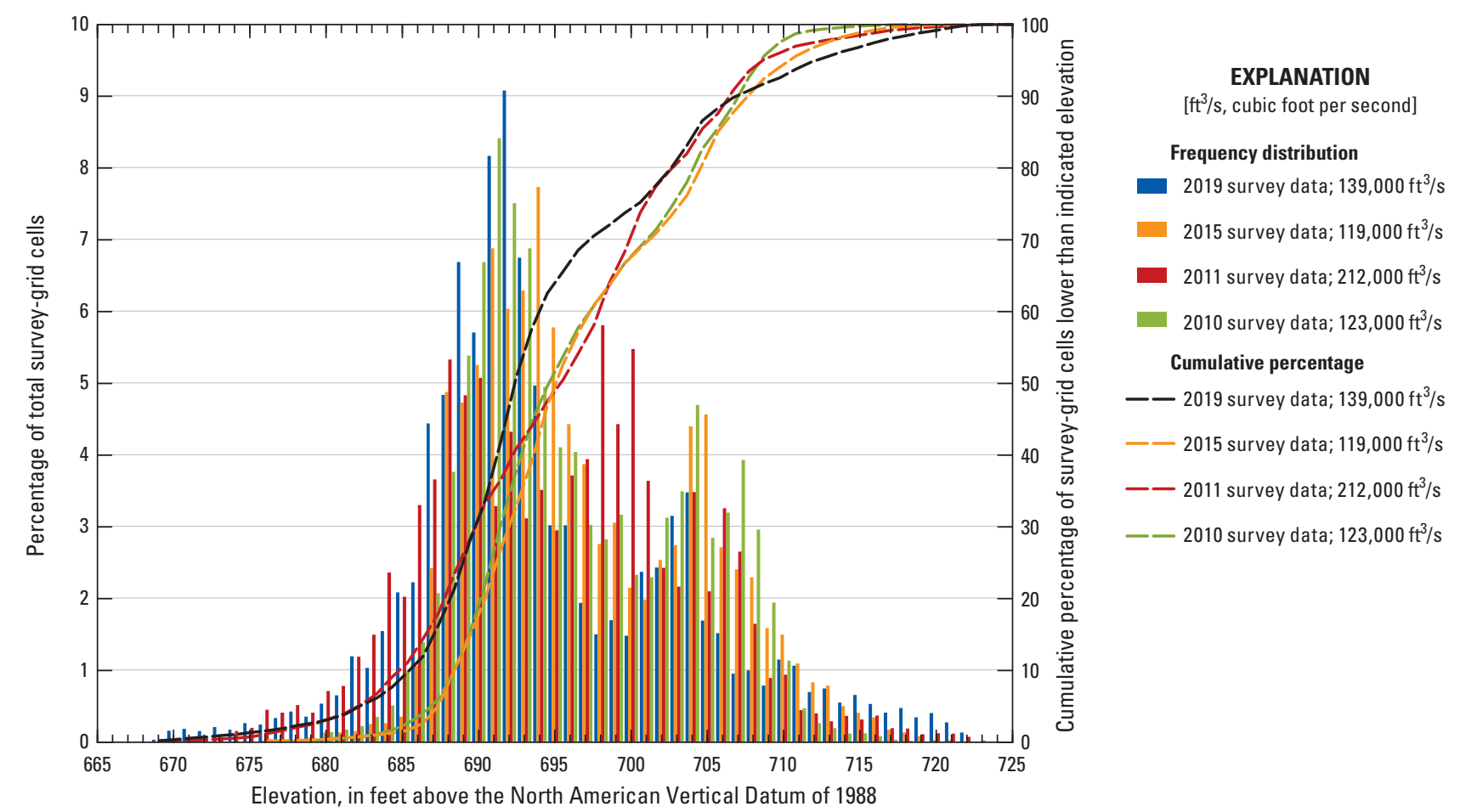

Figure 52. Frequency distribution of bed elevations for bathymetric survey-grid cells in 1-foot elevation bins on the Missouri River near structure A0767 on Interstate 435 in Kansas City, Missouri, on August 14, 2019, compared to previous surveys in 2010, 2011, and 2015 (Huizinga, 2010, 2012, 2016, respectively).

bridge show the substantial difference in the surveyed sections (fig. 53). The frequency distribution of bed elevations in 2019 was remarkably similar to 2011 (fig. 52), but a slightly higher percentage of cells was at a lower channel-bed elevation than 2011 in the middle of the range (fig. 52). The scour hole near main channel pier 7 is shallower and narrower than in 2015, as indicated by the area of deposition in a horseshoe shape around that pier (fig. 55). The bedrock outcrops and stone revetment on the left (north) bank showed signs of localized deposition throughout the reach between 2011 and 2019 (fig. 55); however, the differences on the tops of the outcrops were within the uncertainties of the data, which implies there may be a slight horizontal offset to the 2019 data on the bank that is creating the appearance of deposition on the bank.

The difference between the survey on August 14, 2019, and the earliest nonflood survey on March 17, 2010 (fig. 56), indicates about 80 percent of the joint area of interest had detectable change, which means about 20 percent of the differences in the joint area of interest are equivocal and within the uncertainty. Bed variation seemed nearly equal between scour and deposition from 2010 to 2019 in the DoD map, deposition was predominant along the thalweg on the left (north) side of the channel, and scour was predominant along the middle and right (south) side (fig. 56). However, the average difference between the bathymetric surfaces was $-4.47 \mathrm{ft}$ (table 7 ), indicating substantial channel degradation between the 2010 and 2019 surveys. The net volume of cut in the reach from 2010 to 2019 was about $192,700 \mathrm{yd}^{3}$, and the net volume of fill was only about $13,700 \mathrm{yd}^{3}$, resulting in a net loss of about 179,000 $\mathrm{yd}^{3}$ of sediment between 2010 and 2019. The cross sections from the two surveys along the upstream face of the bridge are similar to each other between the left (north) bank and pier 7 but are substantially different between pier 7 and the spur dike (fig. 53). The frequency distribution of bed elevations in 2019 seemed similar to 2010 but had a higher percentage of cells at lower channel-bed elevations than 2010 (fig. 52); however, the surveyed area was substantially wider in 2019 than in 2010 and extended higher on the channel banks, particularly on the right (south) side (fig. 56). The bedrock outcrops and stone revetment on the left (north) bank showed signs of minor, localized deposition and scour (fig. 56); however, much of the differences on the left (north) side of the channel - and particularly the tops of the outcrops - were again within the uncertainties of the data, as would be expected. As with previous DoD maps, substantial deposition or scour apparent at the faces of the pier footings results from minor horizontal positional variances between the surveys (see "Uncertainty Estimation" section).

The vertically averaged velocity vectors indicate mostly uniform flow throughout the reach, ranging from about $2 \mathrm{ft} / \mathrm{s}$ along the inside of the bend on the right (south) bank to $9 \mathrm{ft} / \mathrm{s}$ in the thalweg (fig. 57); however, turbulence and velocity 


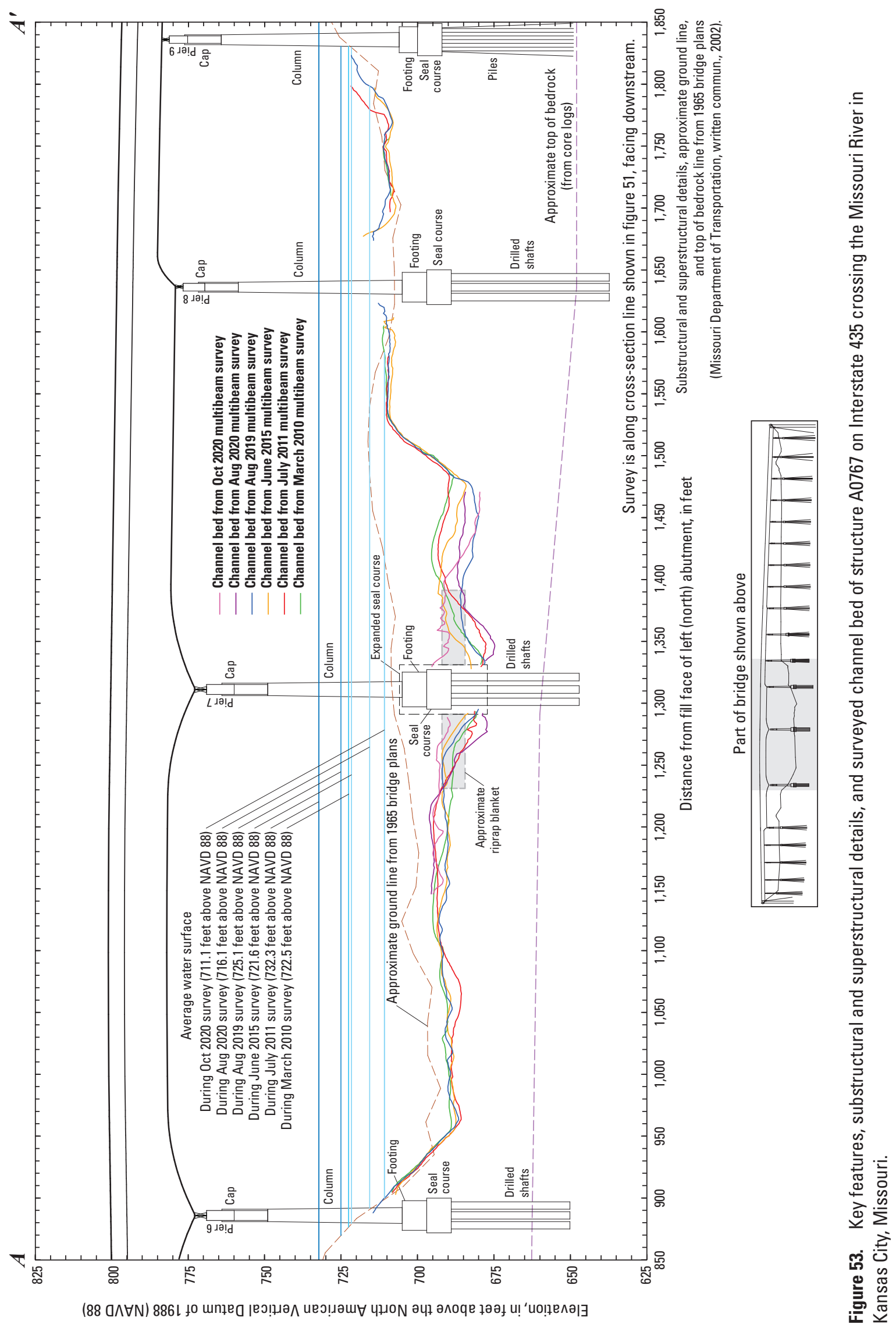




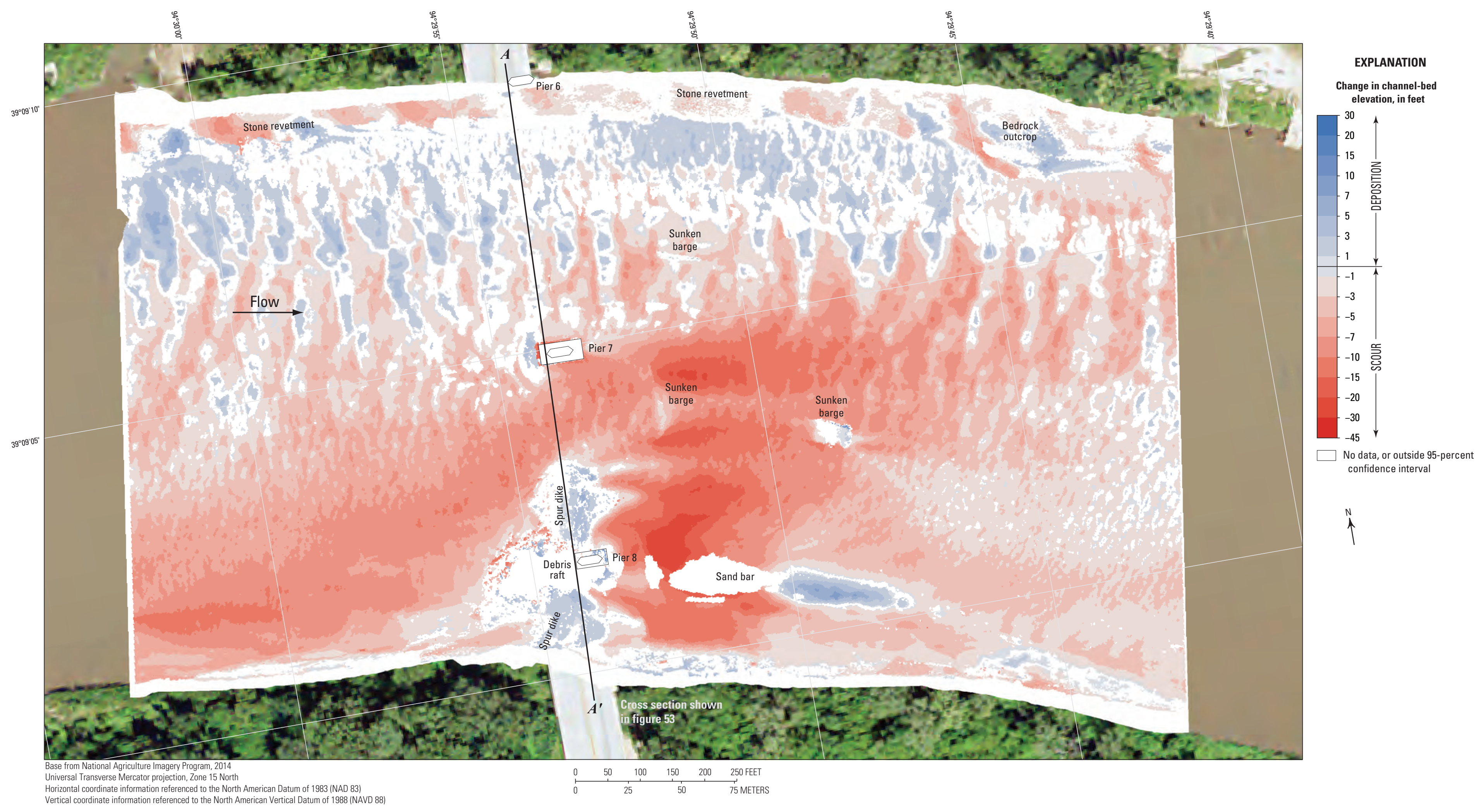

Figure 54. Difference between surfaces created from bathymetric surveys of the Missouri River channel near structure A0767 on Interstate 435 in Kansas City, Missouri, on August 14, 2019 , and June 4, 2015. 


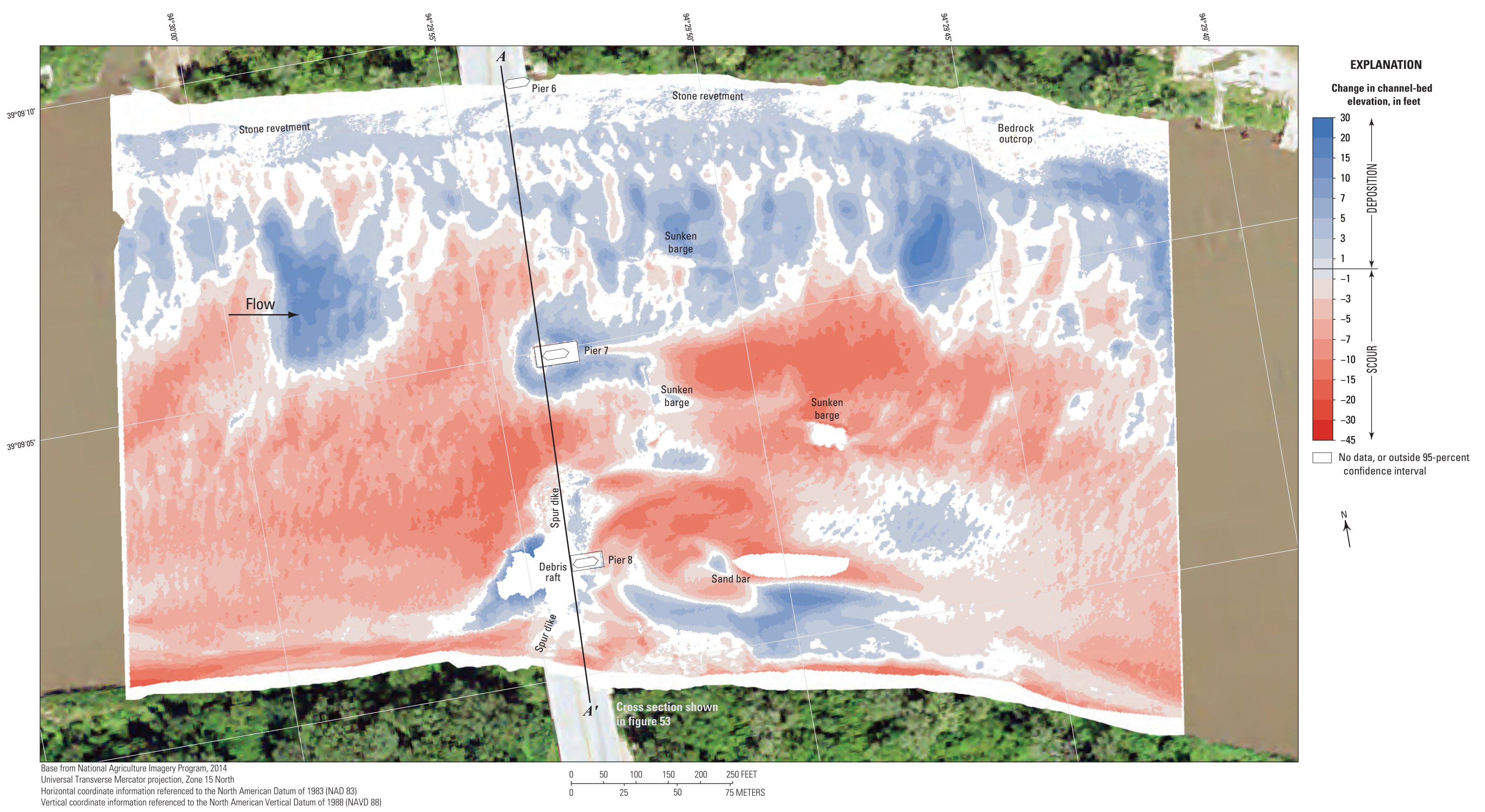

Figure 55. Difference between surfaces created from bathymetric surveys of the Missouri River channel near structure A0767 on Interstate 435 in Kansas City, Missouri, on August 14, 2019 , and July 18, 2011. 


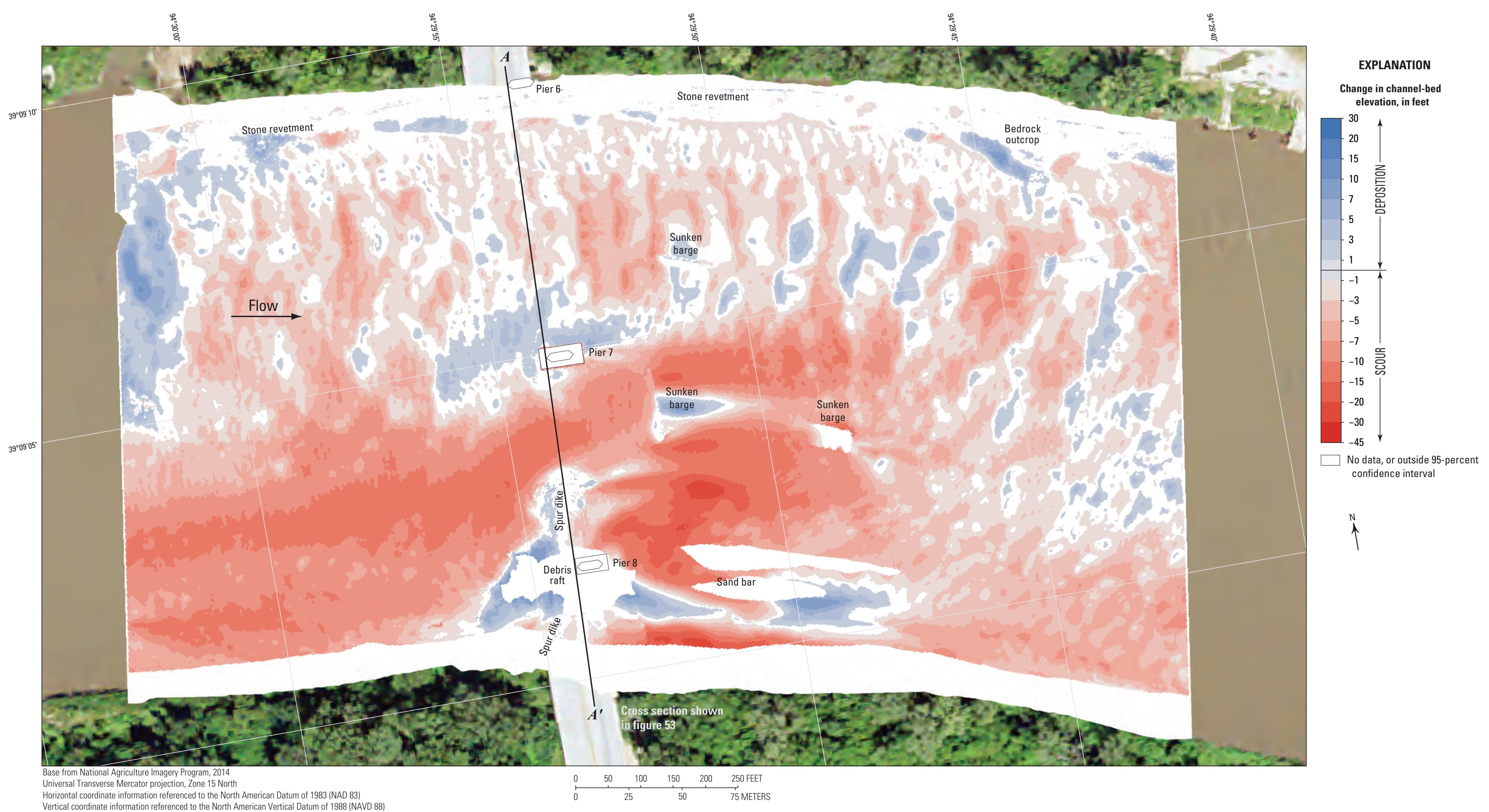

Figure 56. Difference between surfaces created from bathymetric surveys of the Missouri River channel near structure A0767 on Interstate 435 in Kansas City, Missouri, on August 14, 2019 , and March 17, 2010. 


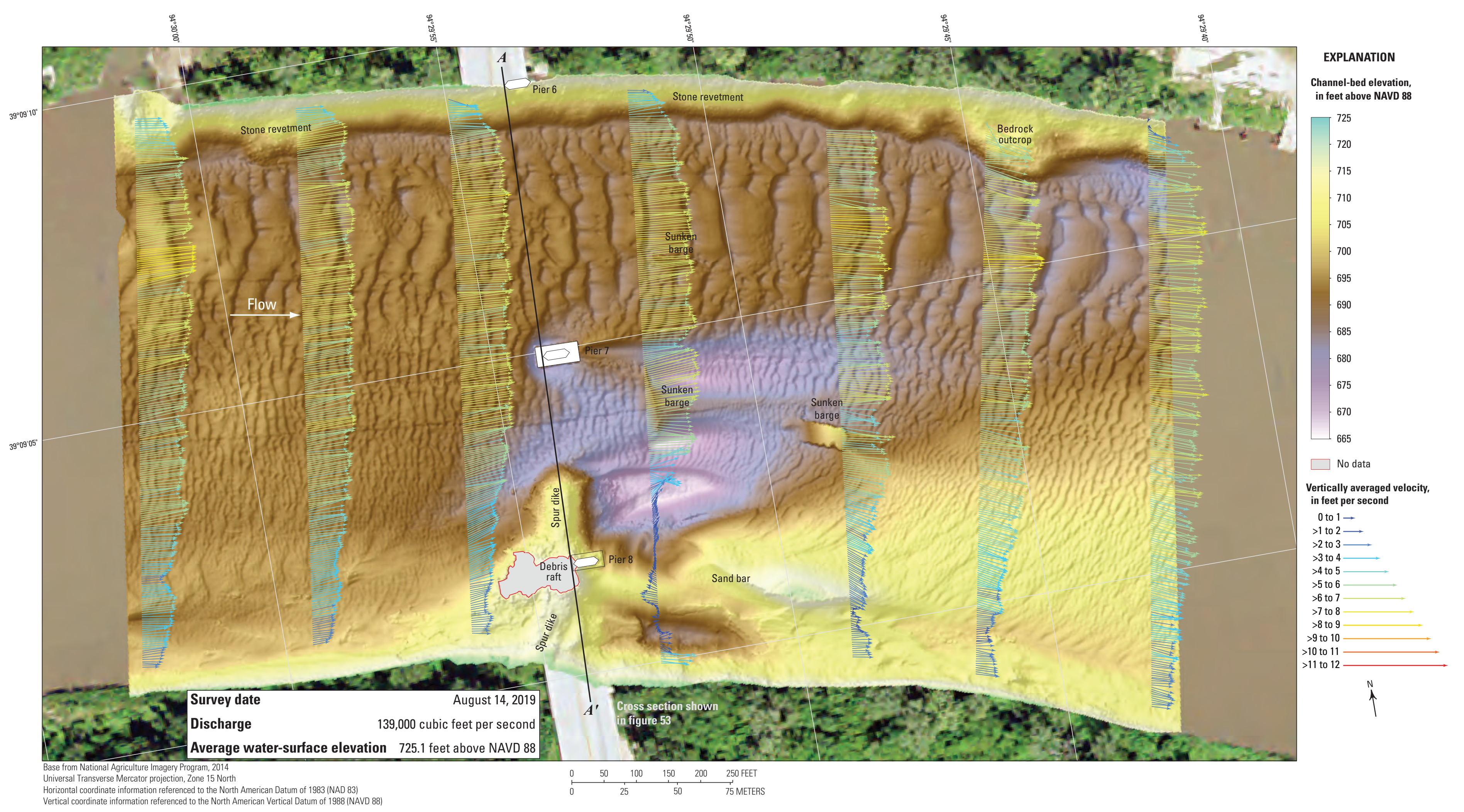

Figure 57. Bathymetry and vertically averaged velocities of the Missouri River channel near structure A0767 on Interstate 435 in Kansas City, Missouri, on August 14, 2019. 
reduction were observed downstream from the spur dike, debris raft, and pier 8, and moderate turbulence was observed in several transects (fig. 57).

The history of scour observed near pier 7 (Huizinga, 2010, 2012, 2016) led MoDOT to install scour countermeasures around pier 7 during August-October 2020. Partial surveys of the channel bed near pier 7 of structure A0767 were surveyed before and after installation of these scour countermeasures to document and verify installation. The historical scour hole near pier 7 was clearly evident in the pre-installation survey on August 17, 2020 (fig. 58), but the cofferdam for an expanded seal course had been partially installed, creating a partially widened footprint to the pier (fig. 58). The difference between the survey on August 13, 2019, and the partial survey on August 17, 2020, indicates moderate deposition of 3 to $7 \mathrm{ft}$ had occurred in much of the partial reach from 2019 to 2020 , but that scour of 15 to $20 \mathrm{ft}$ had occurred near the pier (fig. 59). The cross sections from the two surveys along the upstream face of the bridge also indicates this deeper and wider scour hole at the pier in 2020 (fig. 53). The downstream and right (south) edges of the riprap blanket countermeasure installed around pier 7 was clearly evident in the post-installation survey on October 23, 2020 (figs. $60,1.9 \mathrm{~B}$ ), and the difference between the pre- and postinstallation surveys indicate the changes resulting from the installation (fig. 61). The net volume of cut in the partial reach from August 2019 to August 2020 was about 3,100 $\mathrm{yd}^{3}$, and the net volume of fill was about $14,300 \mathrm{yd}^{3}$, resulting in a net gain of about 11,200 $\mathrm{yd}^{3}$ of sediment between August 2019 and August 2020 (fig. 59). The net volume of cut in the partial reach from August to October 2020 was about 5,300 $\mathrm{yd}^{3}$, and the net volume of fill was about $8,400 \mathrm{yd}^{3}$, resulting in an additional net gain of about $3,100 \mathrm{yd}^{3}$ of sediment between August and October 2020 (fig. 61). The scour hole was effectively mitigated because as much as $27 \mathrm{ft}$ of deposition was near the pier (fig. 61), including some deposition of alluvial material on top of the blanket upstream from the bridge (fig. 60); nevertheless, moderate scour occurred in much of the partial reach around the riprap blanket between August and October (fig. 61). 


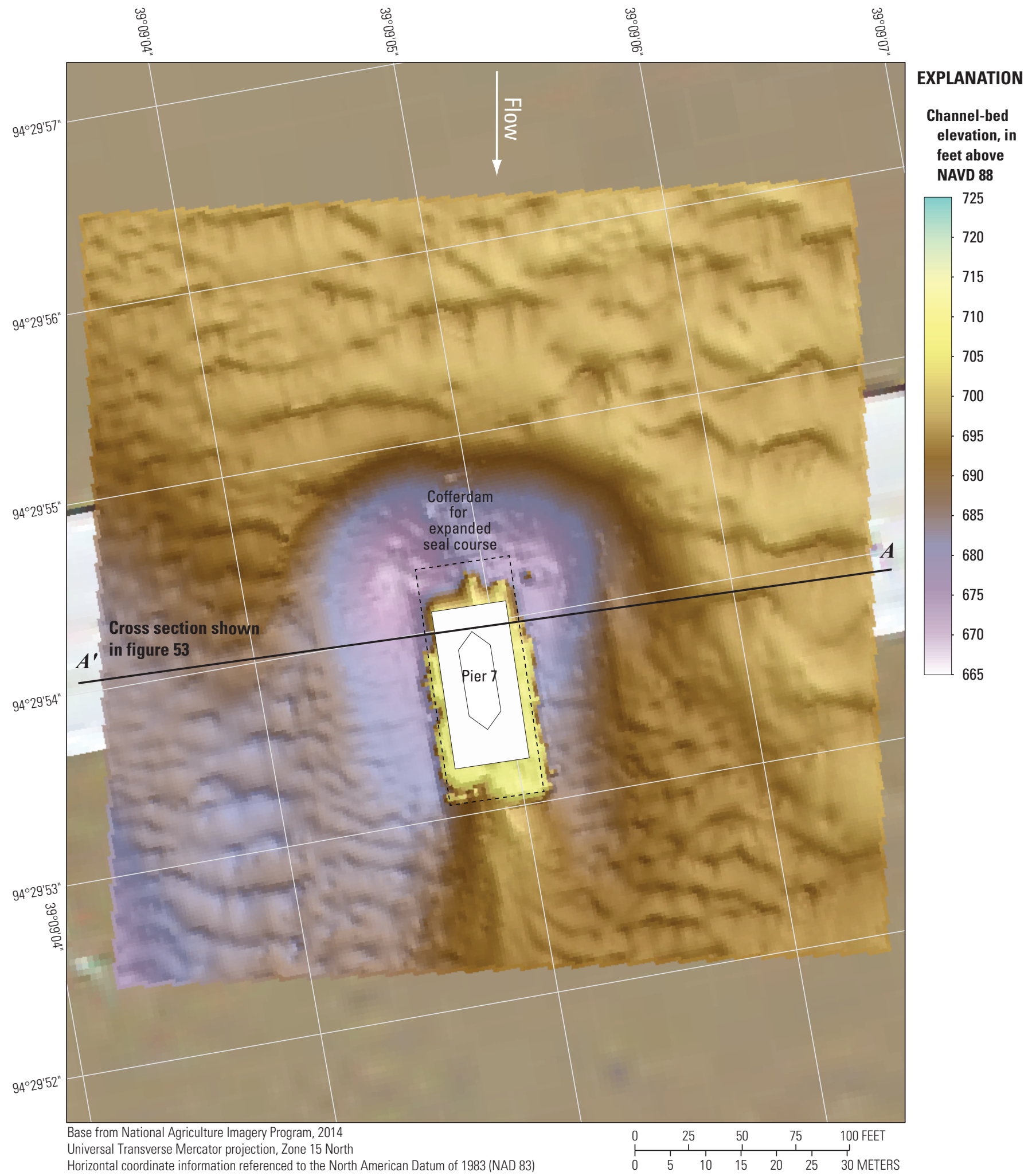

Figure 58. Bathymetric survey of the Missouri River channel near the main channel pier of structure A0767 on Interstate 435 in Kansas City, Missouri, on August 17, 2020, before installation of scour countermeasures. 


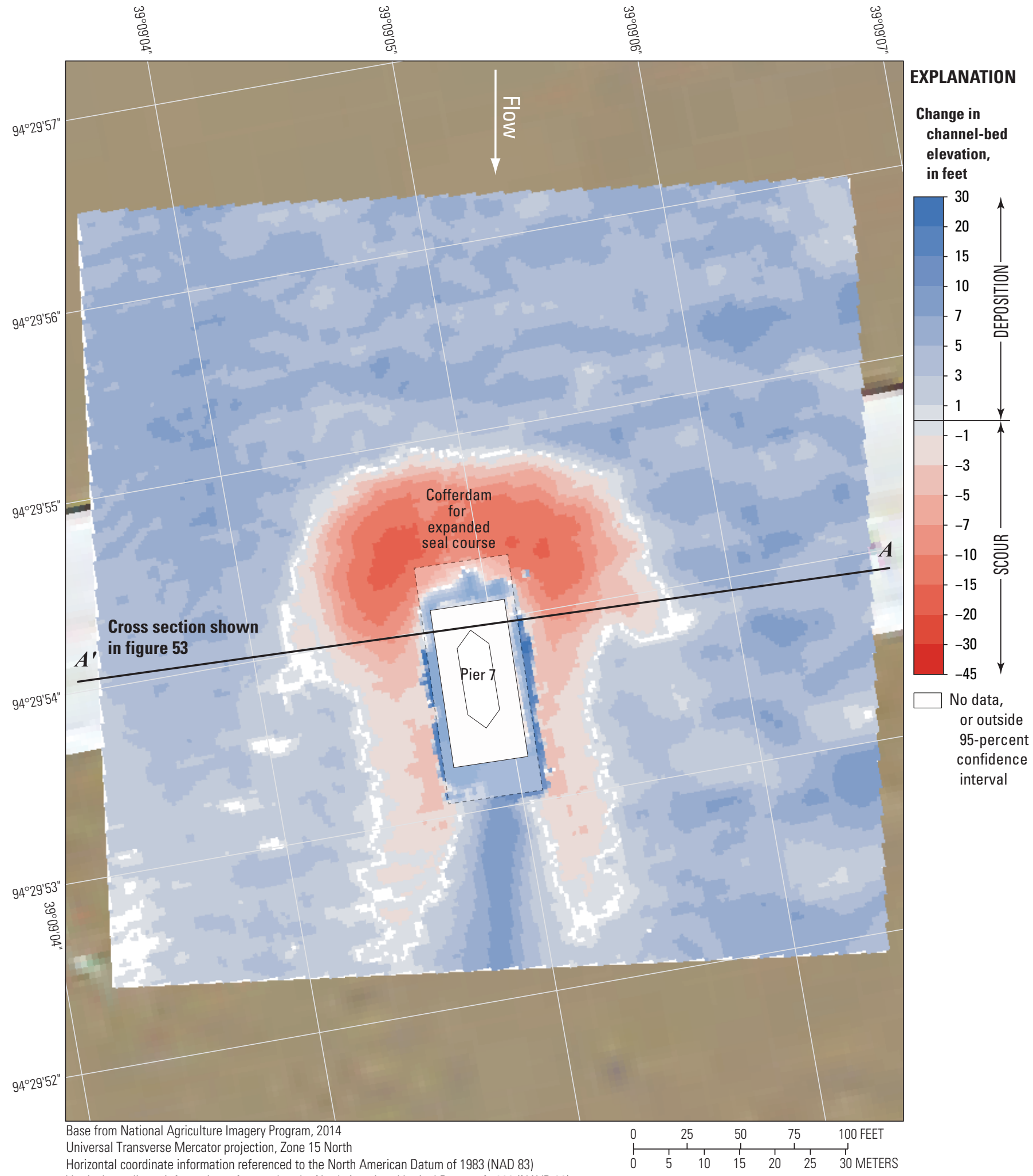

Figure 59. Difference between surfaces created from bathymetric surveys of the Missouri River channel near the main channel pier of structure A0767 on Interstate 435 in Kansas City, Missouri, on August 13, 2019, and August 17, 2020, before installation of scour countermeasures. 


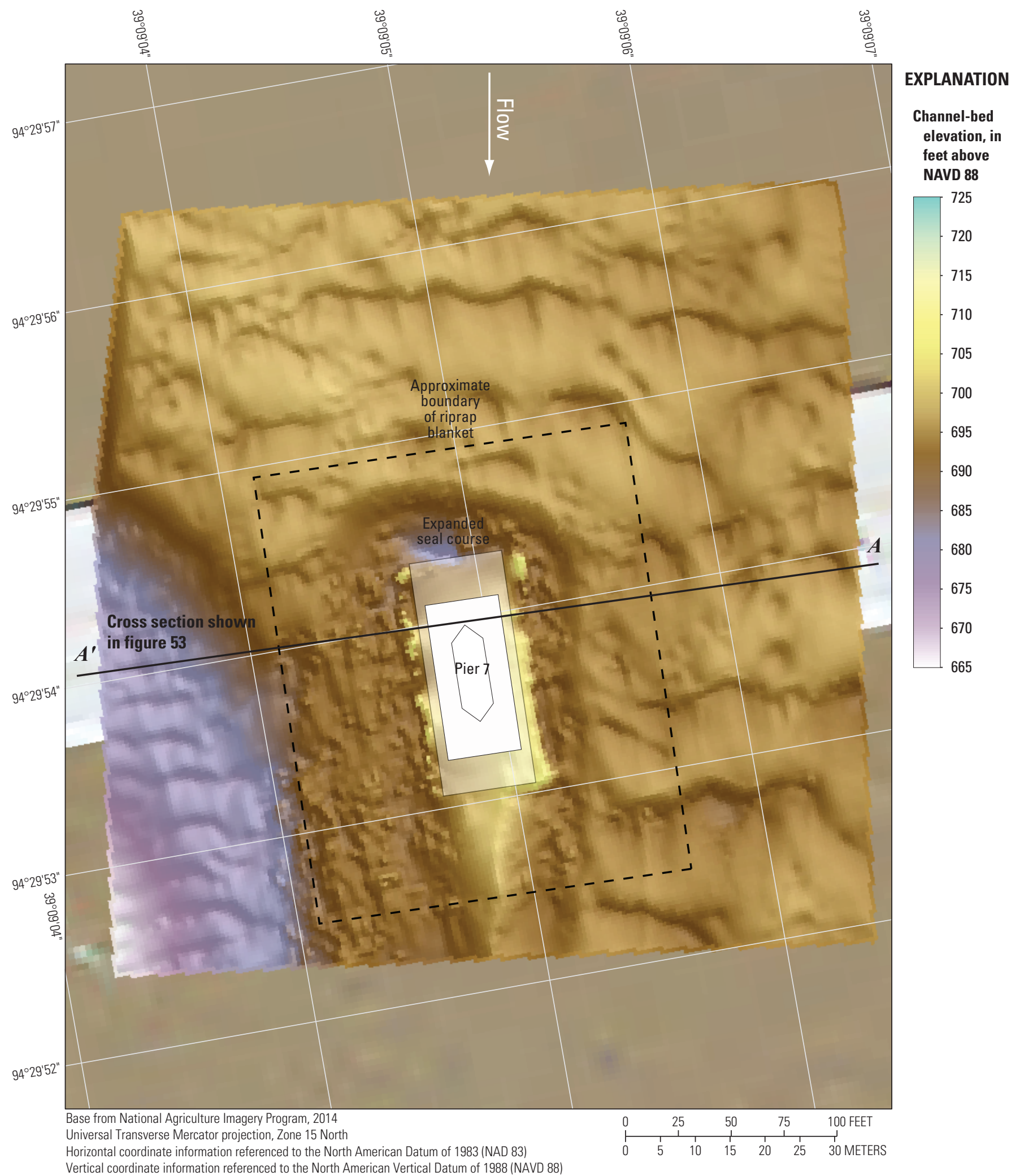

Figure 60. Bathymetric survey of the Missouri River channel near the main channel pier of structure A0767 on Interstate 435 in Kansas City, Missouri, on October 23, 2020, after installation of scour countermeasures. 


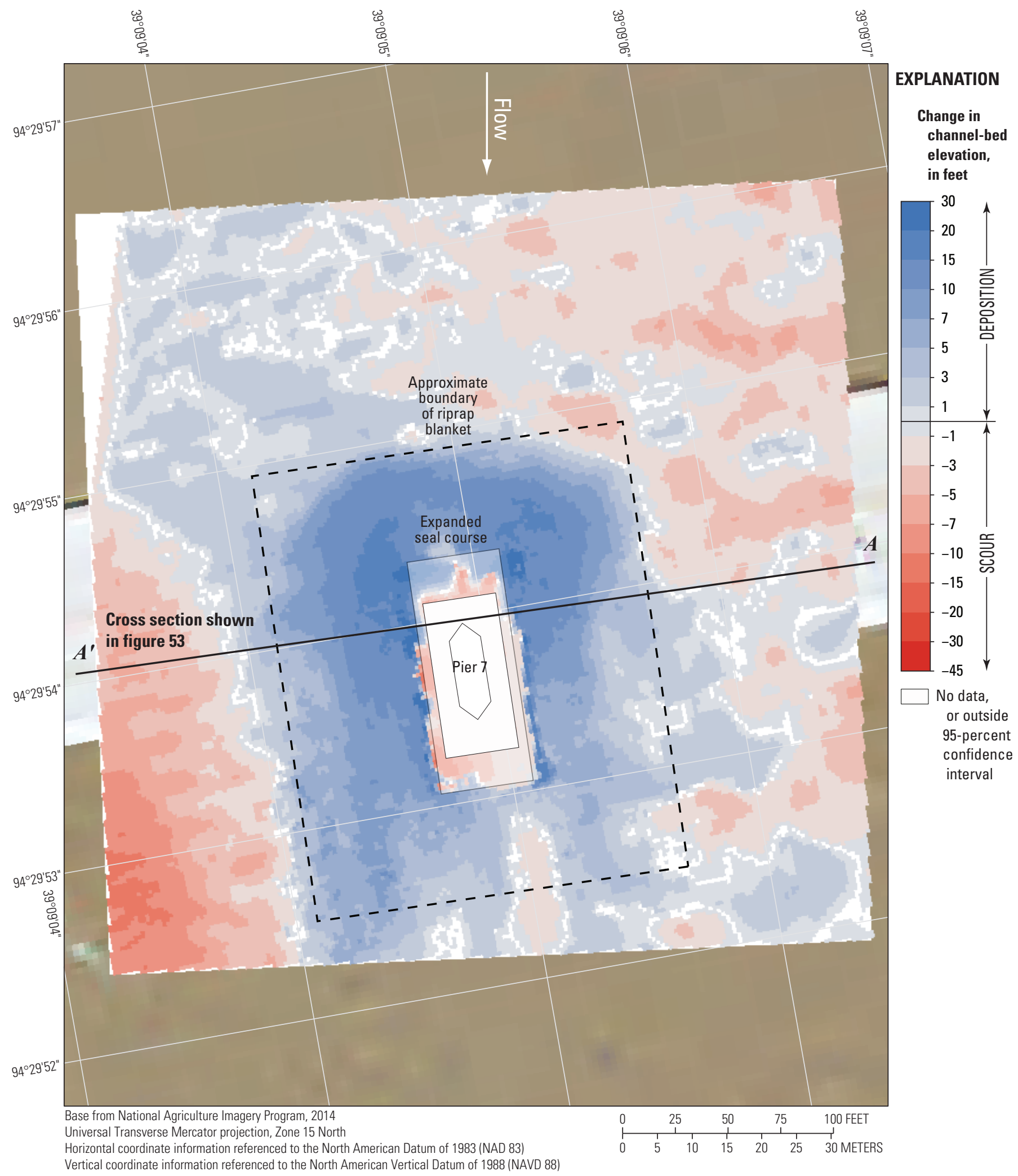

Figure 61. Difference between surfaces created from bathymetric surveys of the Missouri River channel near the main channel pier of structure A0767 on Interstate 435 in Kansas City, Missouri, on August 17 and October 23, 2020, before and after installation of scour countermeasures. 


\section{Structures A4757 and L0568 on State Highway 291}

Structures A4757 and L0568 (site 13; table 1) are dual bridges on State Highway 291, crossing the Missouri River at RM 352.7 on the northeastern side of the Kansas City, Mo., metropolitan area (fig. 1). The site was surveyed on August 14, 2019, and the average water-surface elevation of the river in the survey area, determined by the RTK GPS tide solution, was $720.1 \mathrm{ft}$ (table 5; fig. 62). Streamflow on the Missouri River was about $141,000 \mathrm{ft}^{3} / \mathrm{s}$ during the survey (table 5).

The survey area was about 1,640 ft long and averaged about $890 \mathrm{ft}$ wide, extending from bank to bank in the main channel (fig. 62). The upstream end of the survey area was about $720 \mathrm{ft}$ upstream from the centerline between structures A4757 and L0568 (fig. 42). The channel-bed elevations ranged from about 679 to $706 \mathrm{ft}$ for most of the surveyed area (5th to 95 th percentile range of the bathymetric data; table 5; fig. 63), except near the main channel piers of structures A4757 and L0568 (fig. 62). A channel thalweg was along the left (north) bank throughout the channel and was about $10 \mathrm{ft}$ deeper than the middle of the channel (fig. 62). A row of medium dune features were observed in the thalweg on the left side of the channel, as well as numerous small dunes and ripples throughout the rest of the channel (fig. 62). As in previous surveys at this site (Huizinga, 2010, 2012, 2016), a noticeable channel constriction was at and immediately downstream from the bridges, and the left (north) bank was covered with stone revetment (fig. 62).

A large scour hole near the main channel piers (fig. 62) that essentially encompasses both piers had a minimum channel-bed elevation of about $664 \mathrm{ft}$ (table 6), which also was the minimum channel-bed elevation for the entire reach (table 5). The main channel piers were skewed to the approaching flow, which caused a wide scour hole with somewhat unique characteristics as compared to scour holes at the other surveyed bridges. Pier 5 of structure L0568 was in the wake of pier 2C of structure A4757 and, therefore, had a poorly defined scour hole near it (fig. 62). At the upstream end of pier 2C of structure A4757, the minimum channel-bed elevation was about $664 \mathrm{ft}$, and at the upstream end of pier 5 of structure L0568, the minimum channel-bed elevation was about $672 \mathrm{ft}$ (fig. 62; table 6). Information from bridge plans indicates that the main channel pier $2 \mathrm{C}$ of structure $\mathrm{A} 4757$ is founded on shafts drilled $20 \mathrm{ft}$ into bedrock (fig. 64), and about $45 \mathrm{ft}$ of bed material are between the bottom of the scour hole and bedrock at the point of minimum elevation of the scour hole near the upstream pier face (fig. 64; table 6). At the point of minimum elevation, the surveyed channel bed was about $2 \mathrm{ft}$ below the bottom of the seal course elevation of $666.26 \mathrm{ft}$ (table 6). Information from bridge plans indicate that the main channel pier 5 of structure L0568 is a caisson on bedrock (fig. 65), and about $47 \mathrm{ft}$ of bed material are between the bottom of the scour hole and bedrock at the point of minimum elevation of the scour hole near the downstream right (south) corner (fig. 65; table 6).
The difference between the survey on August 14, 2019 , and the previous nonflood survey on June 4, 2015 (fig. 66), indicates about 74 percent of the joint area of interest had detectable change, which means about 26 percent of the differences in the joint area of interest are equivocal and within the uncertainty. Bed variation seemed nearly equal between scour and deposition from 2015 to 2019 in the DoD map, deposition was predominant from the upstream left through the downstream right of the reach, and scour was predominant from the upstream right to the downstream left (fig. 66). The average difference between the bathymetric surfaces was $-1.51 \mathrm{ft}$ (table 7), indicating minor to moderate degradation between the 2015 and 2019 surveys. The net volume of cut in the reach from 2015 to 2019 was about $82,100 \mathrm{yd}^{3}$, and the net volume of fill was about $25,100 \mathrm{yd}^{3}$, resulting in a net loss of about 57,000 $\mathrm{yd}^{3}$ of sediment between 2015 and 2019. The cross sections from the two surveys along the upstream face of the upstream bridge are similar to each other but generally with uniform scour of 5 to $10 \mathrm{ft}$ across the section (fig. 64). The cross sections from the two surveys along the upstream face of the downstream bridge also are similar to each other but generally with uniform scour of $10 \mathrm{ft}$ across the section (fig. 65). The frequency distribution of bed elevations in 2019 was very similar to 2015, but a higher percentage of cells were at slightly lower channel-bed elevations in 2019 (fig. 63). The scour hole near upstream pier 2C was similar to 2015, as evidenced by the area of equivocal data in a horseshoe shape around the upstream end of that pier in the DoD map (fig. 66). However, the scour hole was slightly deeper near downstream pier 5 than in 2015, as evidenced by the area of scour starting at the downstream side of upstream pier $2 \mathrm{C}$ and extending downstream around pier 5 in the DoD map (fig. 66). The stone revetment on the left (north) bank showed signs of nearly uniform deposition throughout the reach between 2015 and 2019, which is somewhat unexpected (fig. 66); as indicated with others surveys in the current study, there may be a horizontal offset to the 2019 data on the bank that is creating the appearance of deposition. The potential for a horizontal offset is substantiated by the appearance of substantial scour on the left (north) faces and deposition on the right (south) faces of the footing and caisson that likely results from minor horizontal positional variances between the surveys (see "Uncertainty Estimation" section).

The difference between the survey on August 14, 2019, and the previous flood survey on July 19, 2011 (fig. 67), indicates about 85 percent of the joint area of interest had detectable change, which means about 15 percent of the differences in the joint area of interest are equivocal and within the uncertainty. Substantial but approximately balanced bed variation was apparent from 2011 to 2019 in the DoD map, substantial scour was throughout the upstream part and along the right side of the reach, and substantial deposition was along the thalweg along the left (north) side and in the troughs of substantial dunes present in the 2011 survey (Huizinga, 2012, fig. 67). The average difference between the bathymetric 


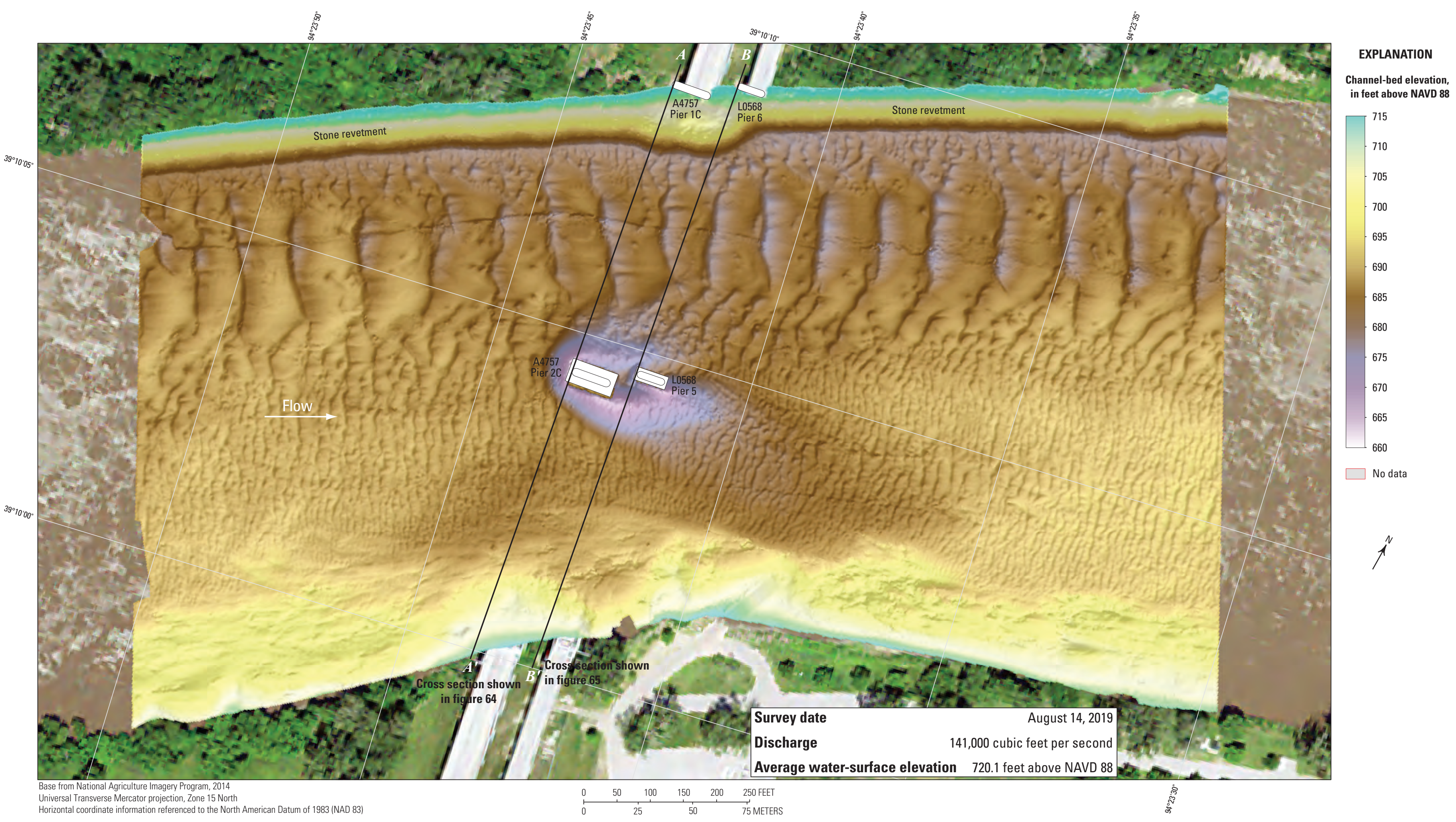

Figure 62. Bathymetric survey of the Missouri River channel near structures A4757 and L0568 on State Highway 291 near Kansas City, Missouri, on August 14, 2019. 


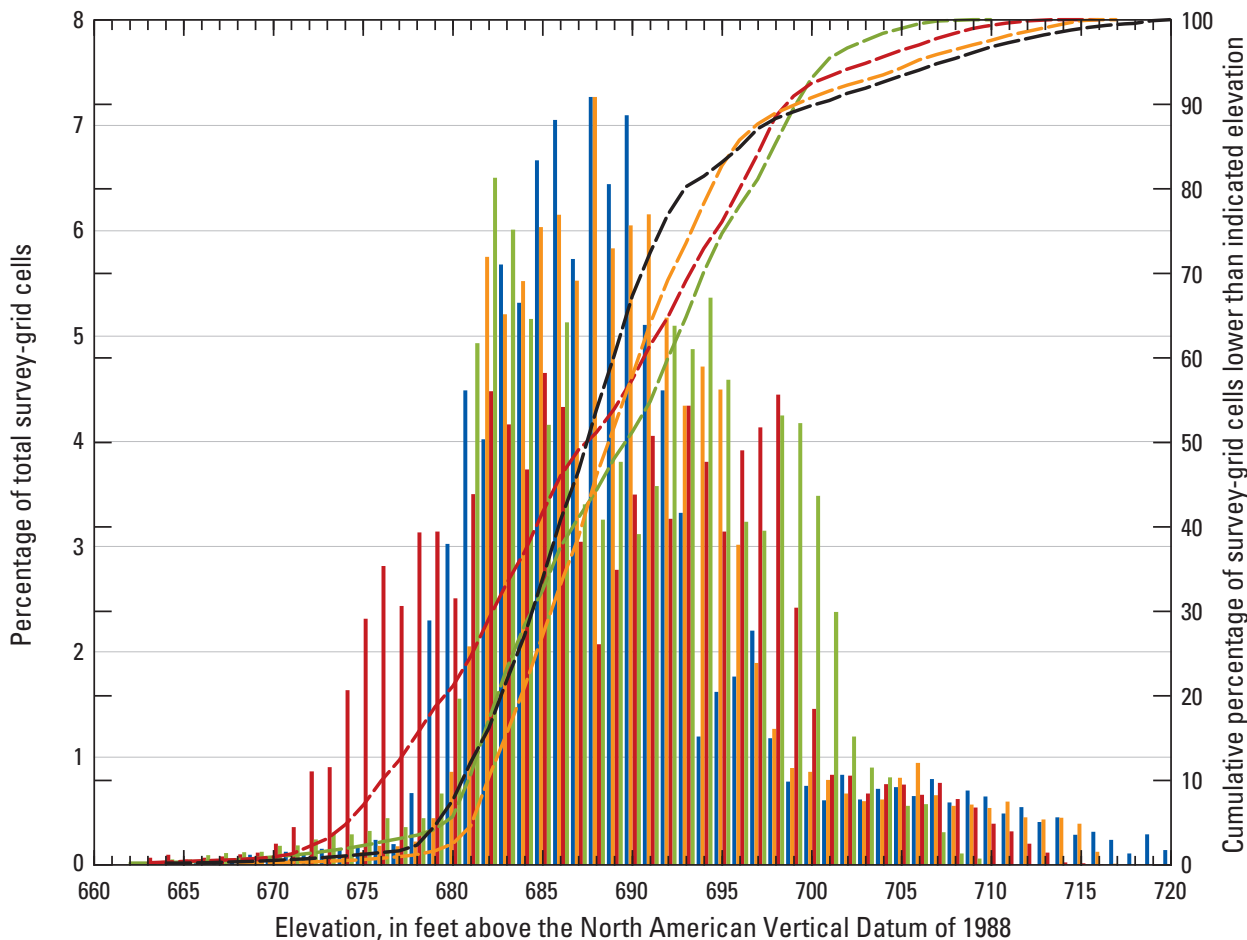

EXPLANATION

$\left[\mathrm{ft}^{3} / \mathrm{s}\right.$, cubic foot per second]

\section{Frequency distribution}

- 2019 survey data; $141,000 \mathrm{ft}^{3} / \mathrm{s}$

2015 survey data; $112,000 \mathrm{ft}^{3} / \mathrm{s}$

- 2011 survey data; $212,000 \mathrm{ft}^{3} / \mathrm{s}$

2010 survey data; $120,000 \mathrm{ft}^{3} / \mathrm{s}$ Cumulative percentage

- 2019 survey data; $141,000 \mathrm{ft}^{3} / \mathrm{s}$

- 2015 survey data; $112,000 \mathrm{ft}^{3} / \mathrm{s}$

- 2011 survey data; $212,000 \mathrm{ft}^{3} / \mathrm{s}$

- 2010 survey data; $120,000 \mathrm{ft}^{3} / \mathrm{s}$

Figure 63. Frequency distribution of bed elevations for bathymetric survey-grid cells in 1-foot elevation bins on the Missouri River near structures A4757 and L0568 on State Highway 291 near Kansas City, Missouri, on August 14, 2019, compared to previous surveys in 2010, 2011, and 2015 (Huizinga, 2010, 2012, 2016, respectively). 


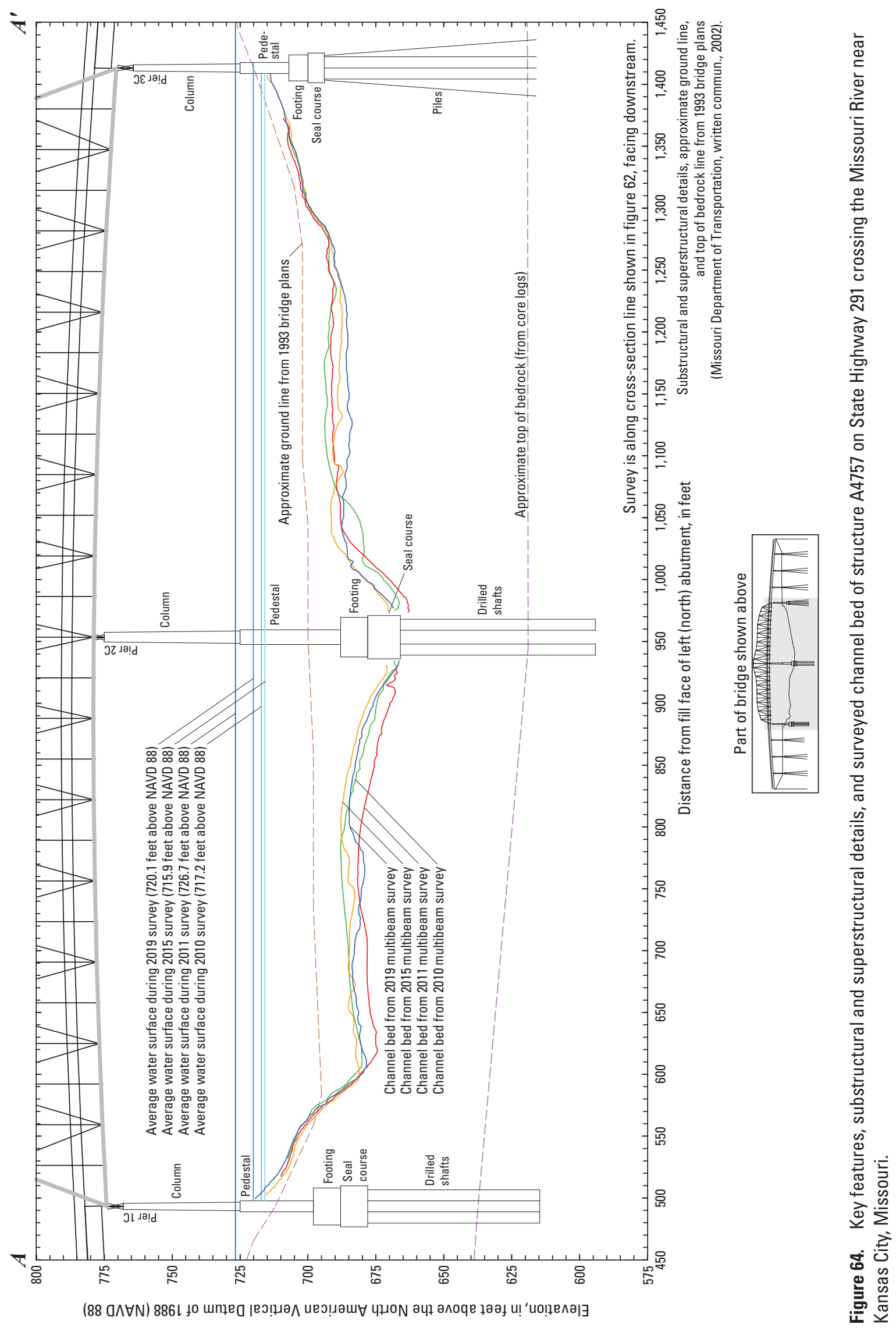




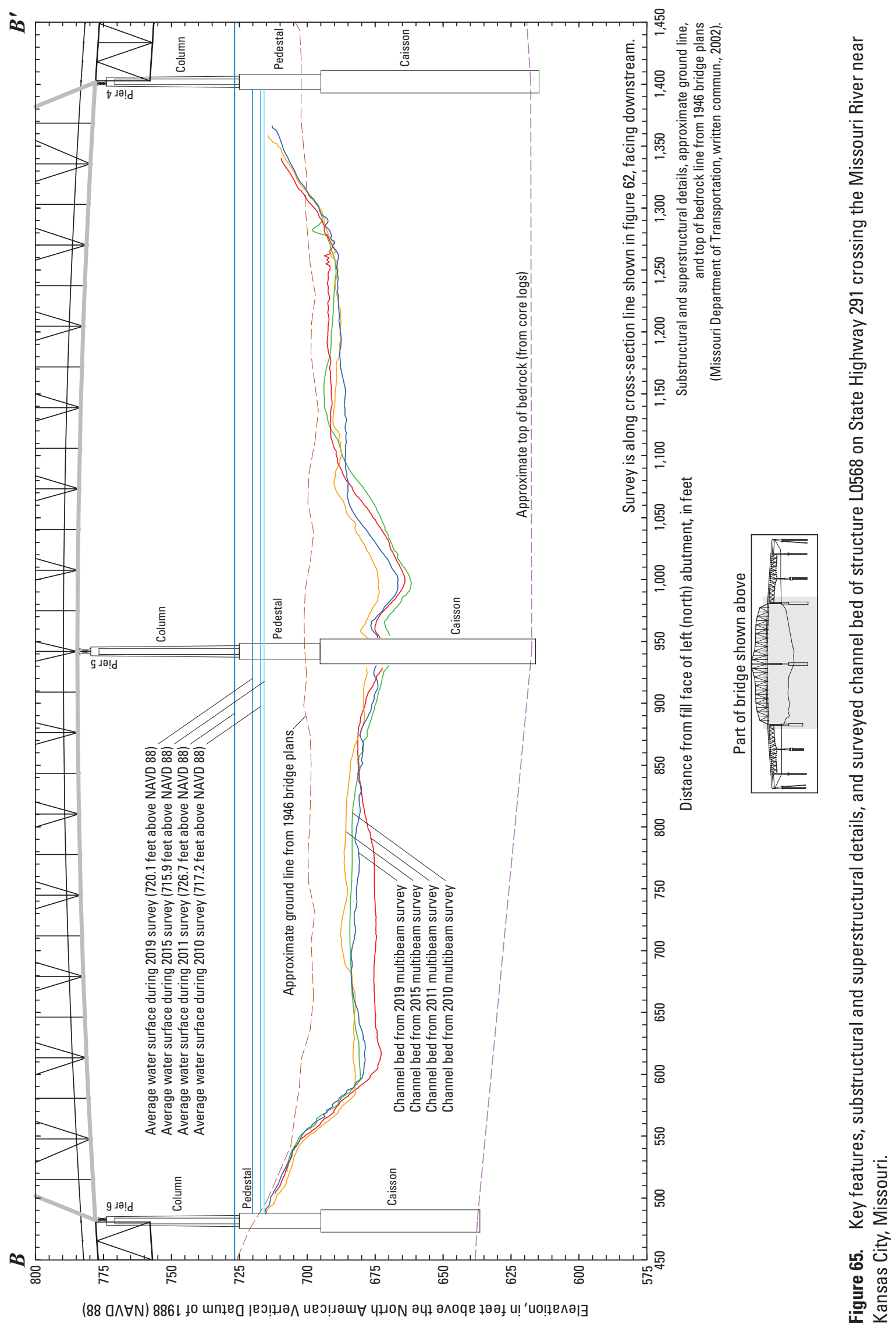




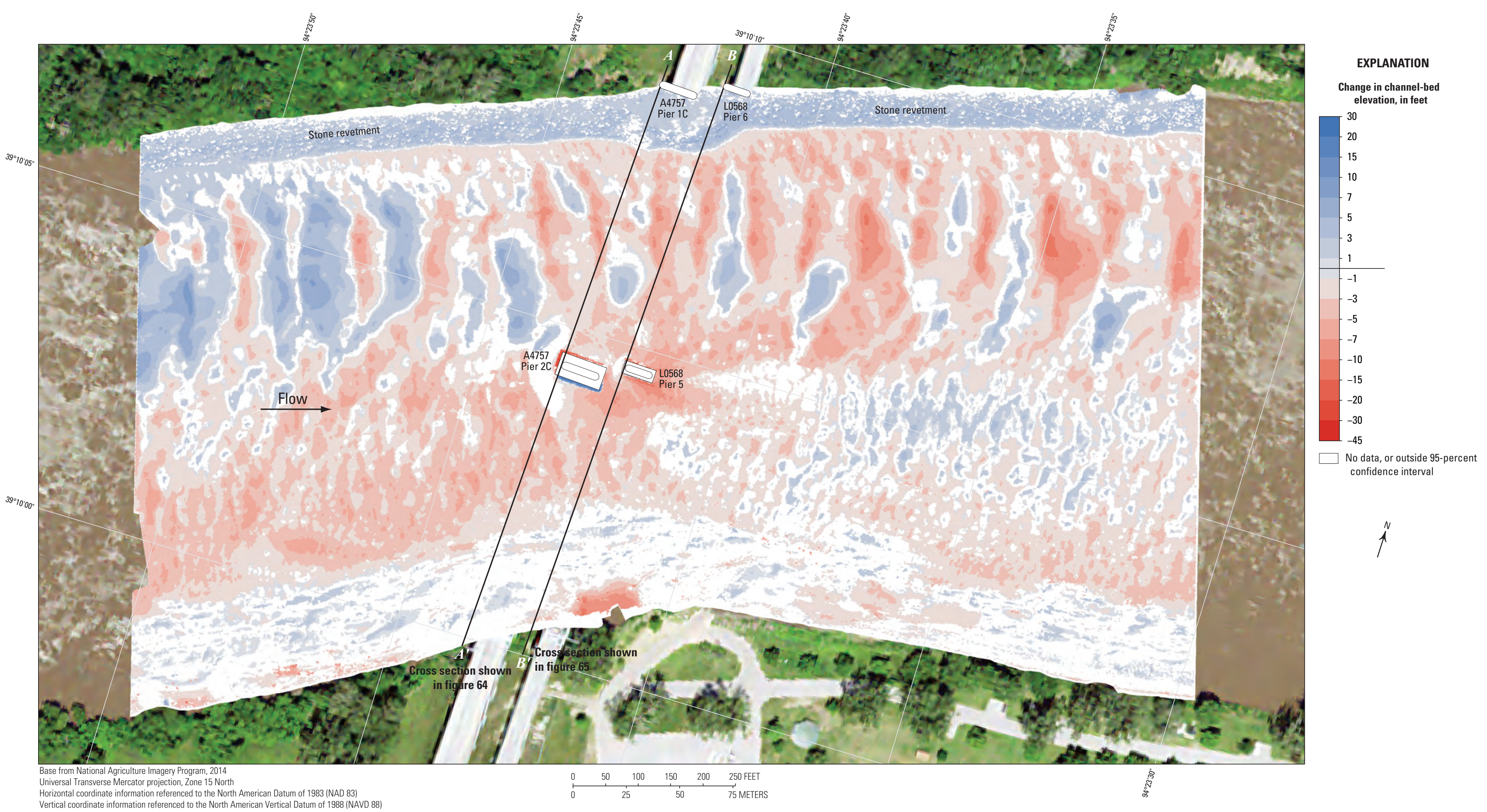

Figure 66. Difference between surfaces created from bathymetric surveys of the Missouri River channel near structures A4757 and L0568 on State Highway 291 near Kansas City, Missouri, on August 14, 2019 , and June 4, 2015. 


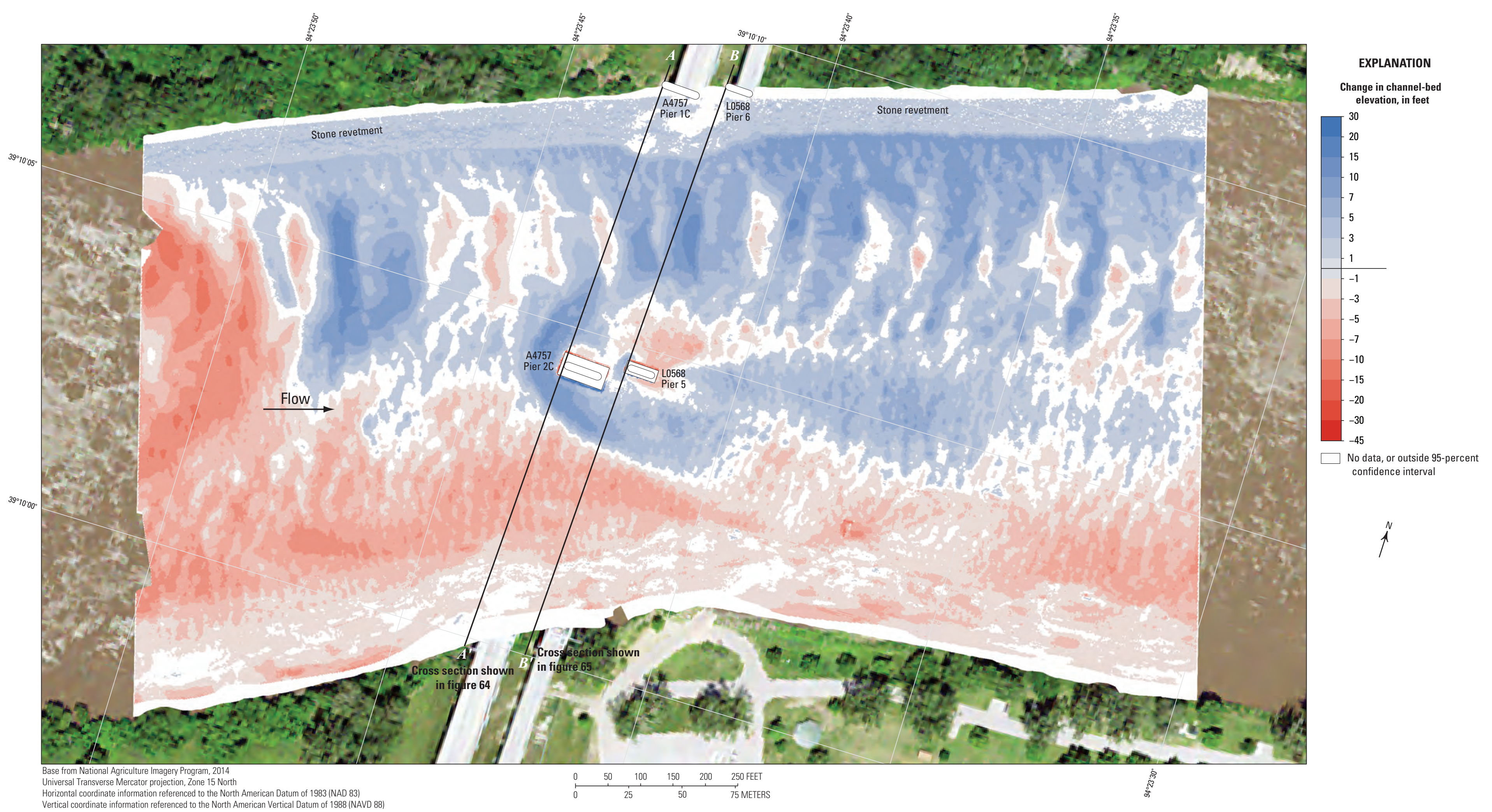

Figure 67. Difference between surfaces created from bathymetric surveys of the Missouri River channel near structures A4757 and L0568 on State Highway 291 near Kansas City, Missouri, on August 14, 2019 , and July 19, 2011. 
surfaces was $+0.22 \mathrm{ft}$ (table 7), indicating little net different between the 2011 and 2019 surveys. The net volume of cut in the reach from 2011 to 2019 was about 77,900 $\mathrm{yd}^{3}$, and the net volume of fill was about $87,400 \mathrm{yd}^{3}$, resulting in a net gain of about $9,500 \mathrm{yd}^{3}$ of sediment in the reach between 2011 and 2019. However, the cross sections from the two surveys along the upstream faces of the bridges show the substantial difference in the surveyed sections (figs. 64, 65). The frequency distribution of bed elevations in 2019 also was substantially narrower than 2011 because a higher percentage of cells was at the middle range of elevations (fig. 63). The DoD map shows that the substantial scour hole at upstream pier $2 \mathrm{C}$ was smaller and shallower in 2019, as evidenced by the horseshoeshaped deposition around the nose of the pier (fig. 67). As with the DoD map for 2015 to 2019 (fig. 66), the stone revetment on the left (north) bank showed signs of localized deposition throughout the reach between 2011 and 2019, which is somewhat unexpected (fig. 67); however, the differences on the tops of steps in the bank were within the uncertainties of the data, which implies there may be a horizontal offset to the 2019 data on the bank that is creating the appearance of deposition. The appearance of substantial scour on the left (north) faces and deposition on the right (south) faces of the footing and caisson also likely results from minor horizontal positional variances between the surveys (see "Uncertainty Estimation" section).

The difference between the survey on August 14, 2019, and the earliest nonflood survey on March 18, 2010 (fig. 68), indicates about 75 percent of the joint area of interest had detectable change, which means about 25 percent of the differences in the joint area of interest are equivocal and within the uncertainty. Substantial but approximately balanced bed variation was apparent from 2010 to 2019 in the DoD map, scour was predominant in the upstream area and along the right (south) bank downstream, and deposition was in the substantial scour hole near the piers and troughs of large dunes in the downstream channel present in the 2010 survey (Huizinga, 2010; fig. 68). The average difference between the bathymetric surfaces was $-2.82 \mathrm{ft}$ (table 7), indicating moderate channel degradation between the 2010 and 2019 surveys. The net volume of cut in the reach from 2010 to 2019 was about $127,200 \mathrm{yd}^{3}$, and the net volume of fill was about $24,600 \mathrm{yd}^{3}$, resulting in a net loss of about $102,600 \mathrm{yd}^{3}$ of sediment between 2010 and 2019. The cross sections from the two surveys along the upstream face of the bridge are similar to each other, except near the piers and between the piers and the right (south) banks (figs. 64, 65). The frequency distribution of bed elevations in 2019 was similar to 2010 at lower elevations but became different with increasing elevation, and a lower percentage of cells was at higher channel-bed elevations (fig. 63); however, the surveyed area was substantially wider in 2019 than in 2010 and extended higher on the channel banks, particularly on the right (south) side (fig. 68). The stone revetment on the left (north) bank showed signs of minor, localized scour and deposition, and much of the difference was within the uncertainties of the data, as would be expected. As with previous DoD maps, and substantial deposition or scour apparent at the faces of the pier footing results from minor horizontal positional variances between the surveys (see "Uncertainty Estimation" section).

The vertically averaged velocity vectors indicate mostly uniform flow throughout the reach, ranging from about $2 \mathrm{ft} / \mathrm{s}$ along the inside of the bend on the right (south) bank to about $9 \mathrm{ft} / \mathrm{s}$ in the thalweg (fig. 69). Exceptions to uniform flow include flows angled to the left (north) near the upstream and downstream faces of the bridges (fig. 69). Moderate turbulence also was observed in several transects, particularly near the bank protrusions near the bridges and downstream from the main channel piers (fig. 69). Velocities were slightly lower downstream from the bridges, likely caused by the flow expansion downstream from the constriction at the bridges (fig. 69). 


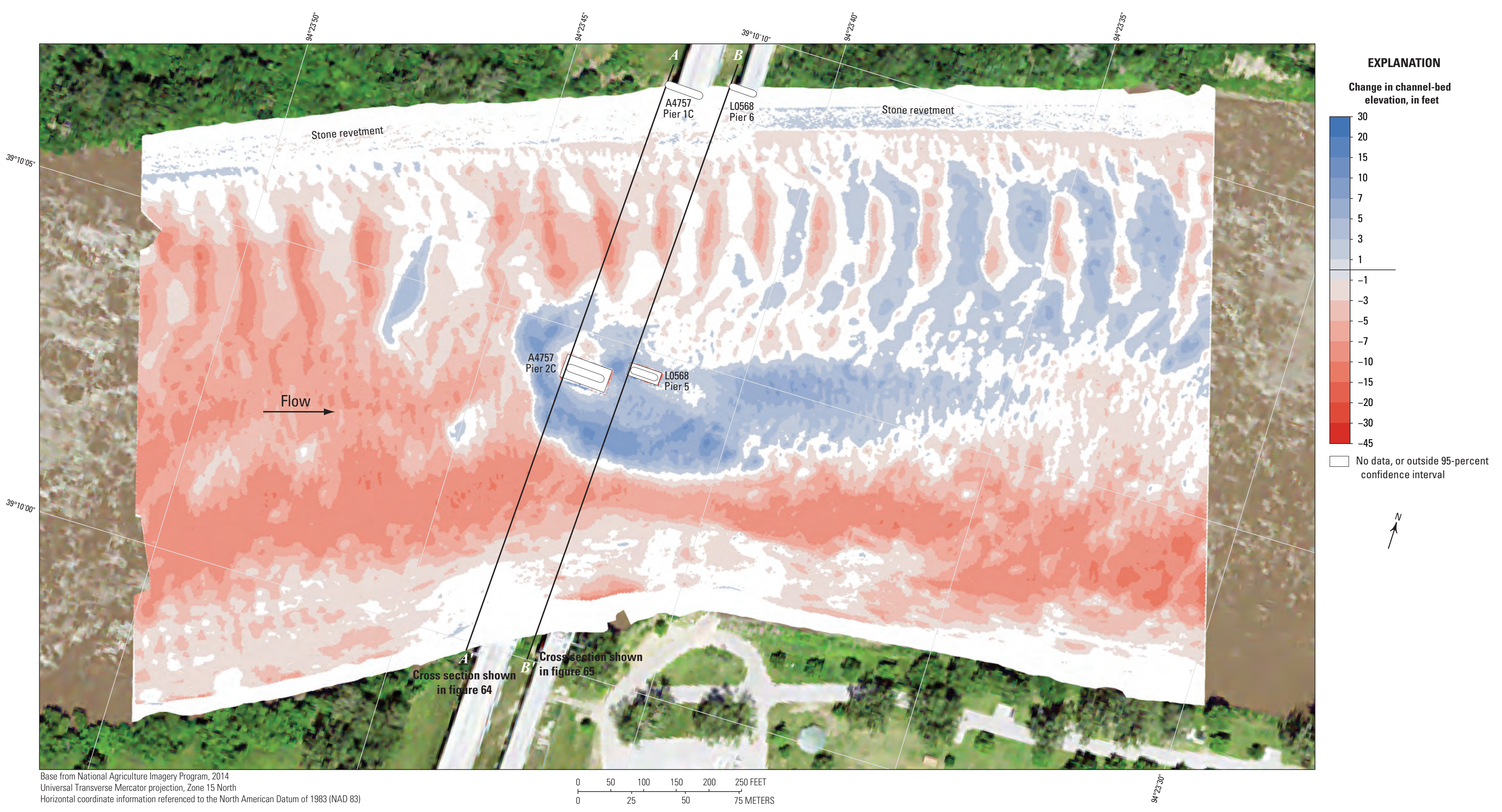

Figure 68. Difference between surfaces created from bathymetric surveys of the Missouri River channel near structures A4757 and L0568 on State Highway 291 near Kansas City, Missouri, on August 14, 2019 , and March 18, 2010. 


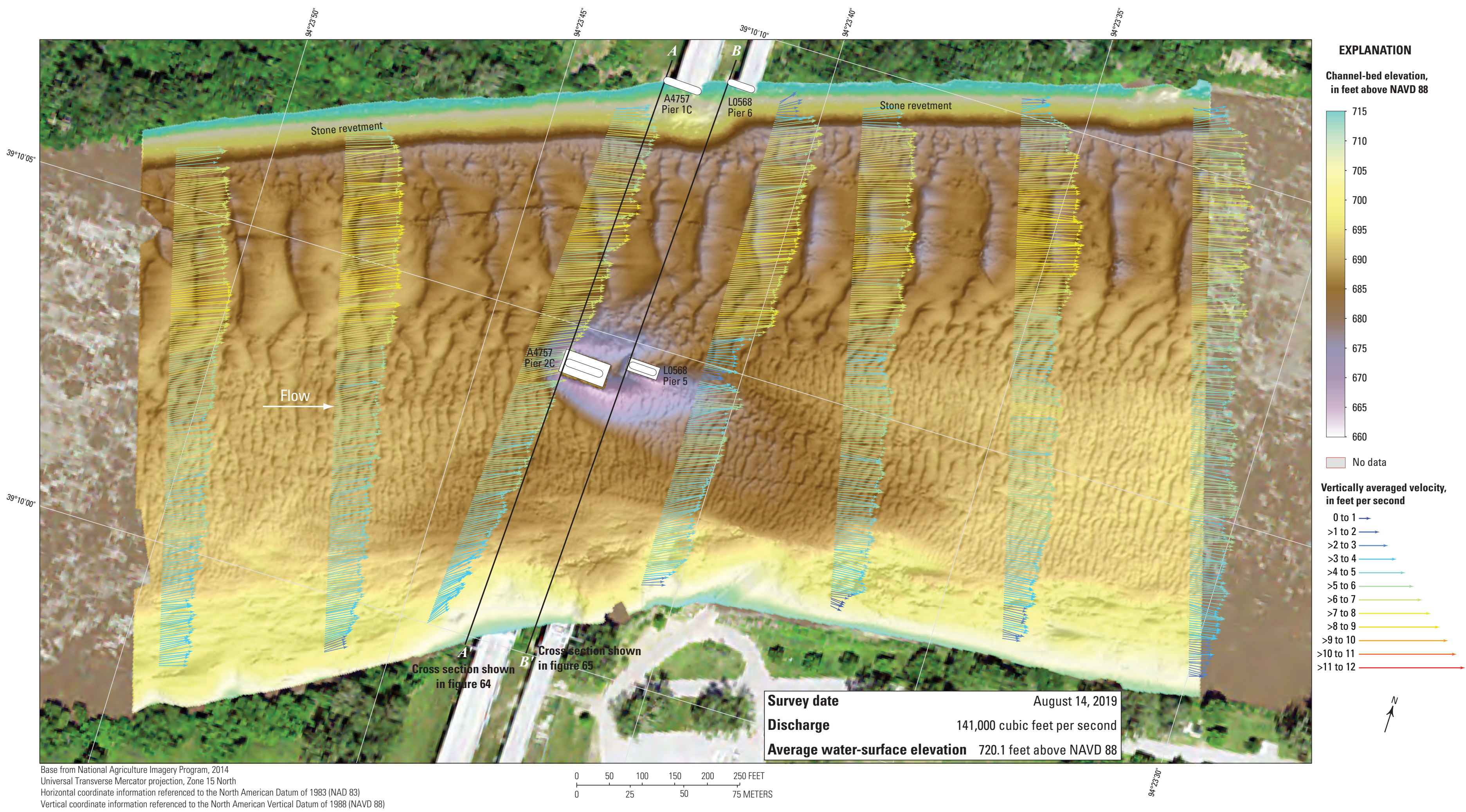

Figure 69. Bathymetry and vertically averaged velocities of the Missouri River channel near structures A4757 and L0568 on State Highway 291 near Kansas City, Missouri, on August 14, 2019. 


\section{General Findings and Implications}

Several of the findings at each surveyed bridge were common to all the bridges, and some findings were evident only when results of the surveys were examined as a set. These general findings are of benefit in the assessment of scour at the surveyed bridges, as well as other bridges close by or in similar settings.

\section{Effects of Moderate Flooding Compared to Previous Surveys}

Arneson and others (2012) separated long-term aggradation and degradation of a channel from the contraction and local scour that happens at a bridge site during floods. Contraction scour is the general change in the channel-bed elevation across a bridge opening resulting from the passage of a flood through a constriction, where more material is in suspension and transport. Local scour is the localized erosion of material caused by flow-vortex action that forms near bridge piers and abutments. Although all the scour processes (long term, contraction, and local scour) continually are at work, contraction and local scour generally are cyclic for the live-bed scour typically observed in alluvial channels and generally result in a decrease and subsequent increase of the channel-bed elevation during and after a flood.

It has been shown in the previous studies with the MBES in the Kansas City area (Huizinga, 2010, 2012, 2016, 2020a) that the configuration and size of bed forms observed during a particular survey depend on more than the instantaneous streamflow at a given site. Several factors and interactions of factors affect sediment transport conditions and the resultant bed configuration. Although it is beyond the scope of the current (2021) study to examine all the antecedent conditions that created the observed channel-bed configuration in the most recent (2019) surveys, the following discussion attempts to draw conclusions based on the conditions observed at each site during the most recent and previous surveys.

As discussed in the previous reports about the Kansas City area bridges (Huizinga, 2010, 2012, 2016, 2020a), most large flood durations on the Missouri River can be measured in days to weeks because of the large upstream contributing drainage area. The presence of dams on the upper Missouri River upstream from Yankton, South Dakota, can lessen the magnitude and lengthen the duration of a given flood wave somewhat because of streamflow regulation, as was seen during the 2011 flood (Huizinga, 2012), but the substantial drainage area contributing unregulated streamflows downstream from Yankton can create substantial variability in the streamflow conditions at Kansas City. As described in the "Description of Streamflow Conditions" section earlier in this report, all the surveys in the current (2021) study were in a trough between minor, mid-summer flood rises; however, the trough happened during generally higher summer flows, which lasted from mid-March past the end of the water year in September (fig. 2). Furthermore, the peak streamflows in March and June were the highest since 1993.

Streamflows at the Kansas City sites during the 2019 surveys ranged from about 1.2 to 1.5 times greater than the streamflow during the 2015 surveys, and average watersurface elevations were 1.5 to $5.1 \mathrm{ft}$ higher in 2019 than in 2015 (table 7). The average differences between the 2019 and 2015 bathymetric surfaces ranged from -0.13 to $-4.17 \mathrm{ft}$, which indicates overall scour between the survey dates (table 7), as might be expected based purely on streamflow at the time of the survey. Streamflows at the Kansas City sites during the 2019 surveys ranged from 33 to 47 percent of the 2011 streamflows, and water-surface elevations were about 6.6 to $13.4 \mathrm{ft}$ lower in 2019 than in 2011 (table 7); nevertheless, the average differences between the 2019 and 2011 bathymetric surfaces ranged from 0.22 to $-4.91 \mathrm{ft}$, which again indicates overall scour (table 7). The smaller average differences between surveys might be considered equivocal based on the uncertainty associated with points recorded for the surveys (table 4) and the 95-percent thresholding used in the difference maps. Nevertheless, these trends are not consistent with what might be expected for scour and deposition based purely on streamflow at the time of the survey. The predominant scour observed between the various surveys implies the channel bed in the 2019 surveys might have still been rebounding from more substantial scour caused by the higher streamflow earlier in March and June. The site with the largest variability in intersurvey average difference was site 8, structure A4649 on U.S. Highway 169 (table 7). The average difference in bed elevation at site 8 indicated minor deposition between 2010 and 2019 (fig. 25) with nearly equal streamflows, substantial scour between 2011 and 2019 (fig. 24) with substantially less streamflow in 2019 , and nearly equivocal scour between 2015 and 2019 (fig. 23) with approximately 34 percent more streamflow. The site with the smallest variability in intersurvey average difference was site 6 , structure A1800 on Interstate 635 (table 7); the average difference in bed elevation at site 6 indicated moderate scour of 1.59 to $2.93 \mathrm{ft}$ between the 2019 and all other surveys.

Examining the average channel-bed and water-surface elevations with time (fig. 70), the water-surface elevations during the 2019 surveys were the second-lowest of the four surveys at the two upstream-most structures A1800 (site 6) and A8340 (site 7), whereas the water-surface elevation during the 2019 surveys were the second-highest of the four surveys at the sites from structure A4649 (site 8) downstream. At sites 7, 8,9 and 11 , the channel bed was at a temporal maximum in 2011, and at sites 7 and 8, the channel bed was at a temporal minimum in 2010. The 2015 and 2019 average channel-bed elevations fell between the 2010 and 2011 surveys at sites 7 and 8 . In contrast, the 2019 survey set or matched the temporal minimum at sites 6 and 9 through 12 (fig. 70). The Kansas River joins the Missouri River immediately upstream from structure A4649 (site 8; fig. 1), and additional inflow from the Kansas River likely accounts for the increased water-surface 


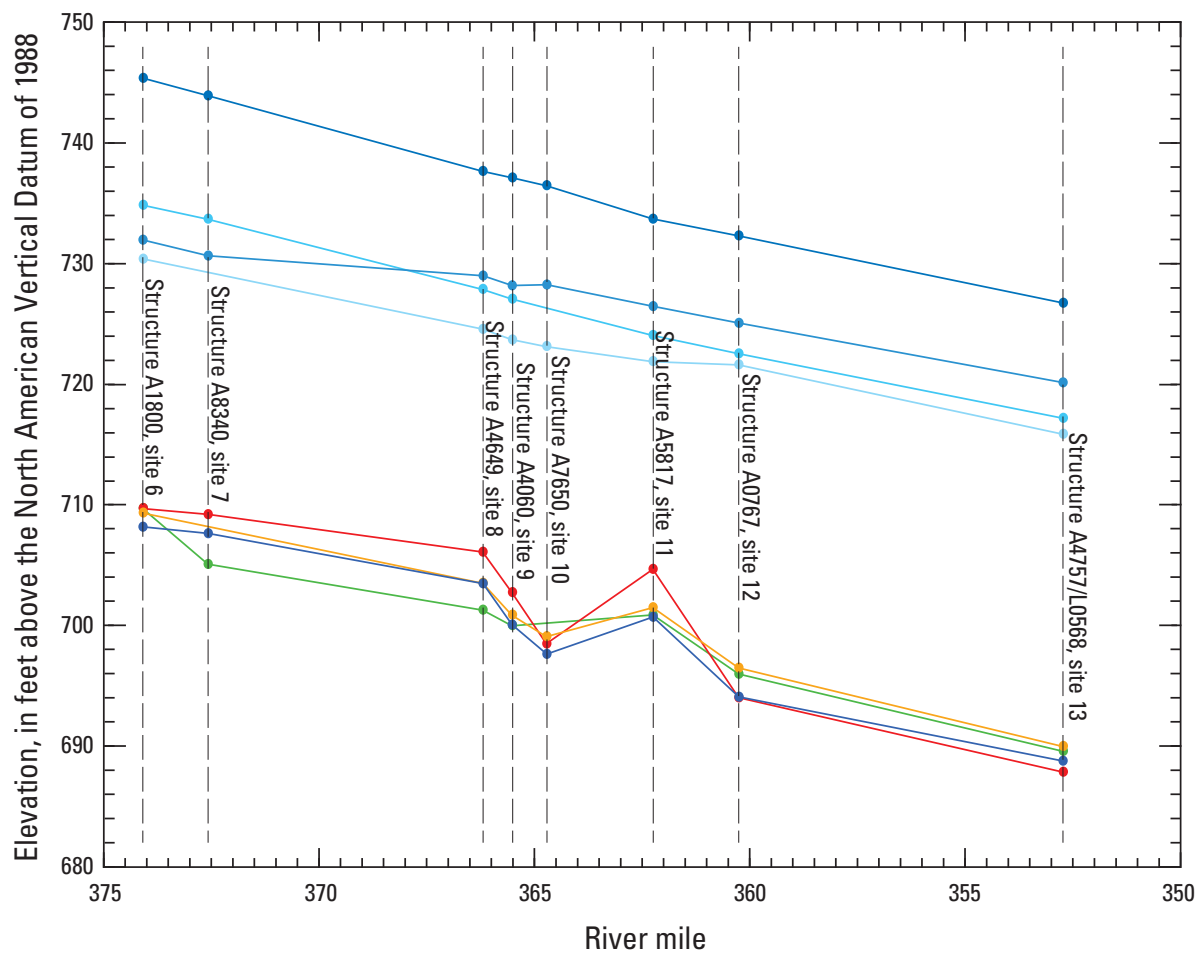

\section{EXPLANATION}

Average water-surface elevation

- 2019 survey data

2015 survey data

- 2011 survey data

- 2010 survey data

Average channel-bed elevation

- 2019 survey data

-2015 survey data

- 2011 survey data

- 2010 survey data

Figure 70. Average channel-bed and water-surface elevations near bridges on the Missouri River near Kansas City, Missouri, from surveys in 2010, 2011, 2015, and 2019 (Huizinga, 2010, 2012, 2016, and this report, respectively).

elevations at site 8 and downstream. The additional inflow may also account for why the average channel-bed elevations are at a temporal minimum in 2019 for nearly all the sites downstream from structure A4649 (site 8; fig. 70). This configuration of average channel-bed elevations and average differences indicates that greater streamflow at the time of the survey alone does not necessarily result in more scour at a site (as would be evidenced by lower average channel-bed elevations with increased streamflow). It was hypothesized in the 2011 flood study at Kansas City (Huizinga, 2012) that a slug of sediment may have been traveling through the upstream part of the Kansas City area at that time, given the substantial increase in channel-bed elevation from 2010 to 2011 at the upstream sites; it was further hypothesized after the 2015 surveys that this slug of sediment had been eroded away between 2011 and 2015 (Huizinga, 2016). The results of the 2019 surveys seem to substantiate that if a slug of sediment indeed was present in 2011, it had eroded away from the upstream sites; furthermore, additional erosion has occurred at nearly all the sites downstream from structure A4649 (site 8) since 2015 (fig. 70) Again, it seems reasonable to assume that the higher streamflows in March and June had a substantial scouring effect in the reach, and the 2019 surveys captured a partial rebound.

The local spatial minimum observed at structure A7650 (site 10) in the 2015 surveys (Huizinga, 2016) persisted in the 2019 surveys (fig. 70) and likely indicates this site is at or near a local feature that controls sediment deposition and scour.
As posited in the report on the 2015 surveys, the feature may be a combination of the constriction at this site (fig. 38) and being near the downstream end of the relatively straight reach of river between structures A4649 and A7650 (fig. 1); furthermore, perhaps the sediment unable to deposit near structure A7650 is flushed downstream and deposits at the next downstream site, structure A5817 (site 11), as indicated by the average channel bed elevation curve (fig. 70). The relatively consistent shape of the frequency distribution and accumulation curves between the surveys at site 10 (fig. 39) further substantiates that the site may be a channel sediment control point, allowing minor deposition during lower streamflows as in 2015 but flushing to a relatively consistent bed-elevation distribution during higher streamflow. An examination of the frequency distributions of the various sites through time (fig. 71) seems to further confirm the scenario of a sediment control feature near structure A7650. The frequency distribution curves for structures A4060 and A7650 tend to have local maxima with a higher percentage of survey-grid cells than other sites in all the surveys (fig. 71A), and the accumulation curves for these two sites generally are steeper than the other surveys in the area (fig. 71B), which indicates a more level bed with less variation in elevation at these sites. As would be expected, these maxima are at a lower elevation than sites upstream from them and generally at a higher elevation than most of sites downstream; however, the distribution curve for downstream site 11 (structure A5817) consistently has a local maximum that is at a higher elevation than the two upstream 

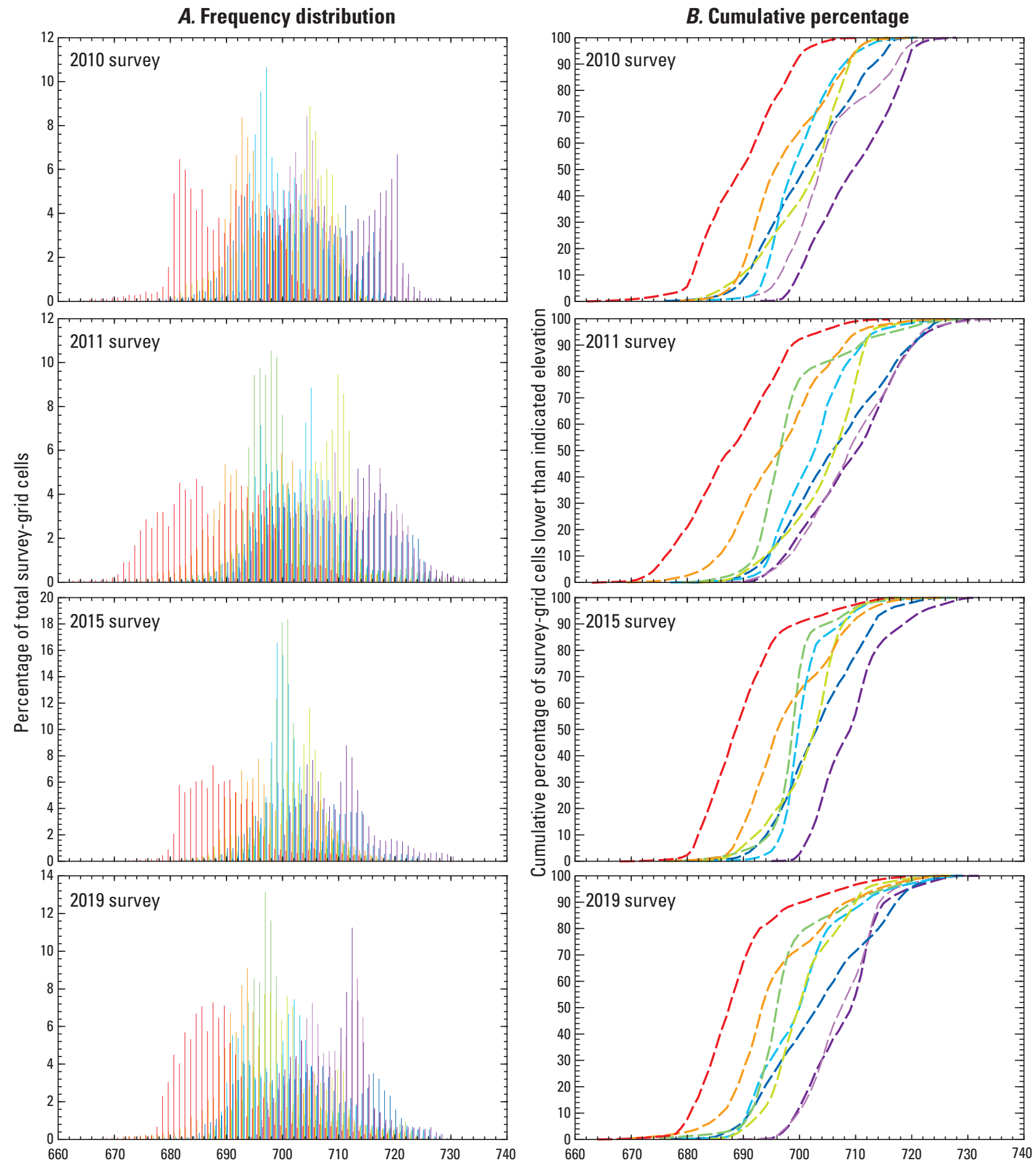

Elevation, in feet above the North American Vertical Datum of 1988

\section{EXPLANATION}

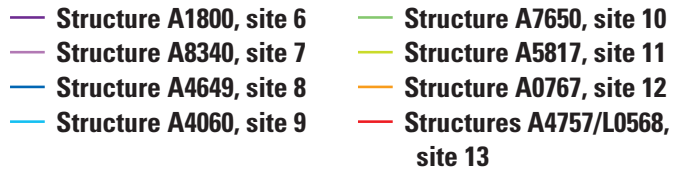

\section{EXPLANATION}

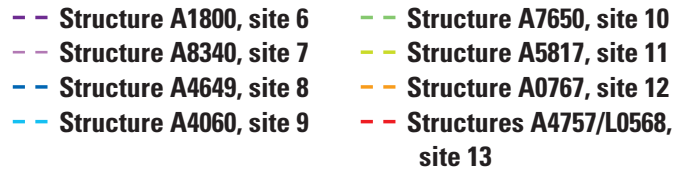

Figure 71. Comparison of frequency distribution and cumulative percentage of bed elevations for bathymetric survey-grid cells in 1-foot elevation bins from various surveys on the Missouri River near Kansas City, Missouri, in 2010, 2011, 2015, and 2019 (Huizinga, 2010, 2012, 2016, and this report, respectively). $A$, frequency distribution. $B$, cumulative percentage. 
sites, and the accumulation curve is to the right of (implying a higher elevation than) several of the upstream sites in the surveys (fig. $71 B$ ).

Further examination of the frequency distributions of the 2019 surveys in relation to the others in 2019 indicates the similarity of several of the sites with a neighboring site or the uniqueness of a given site (fig. 71). For example, sites 6 and 7 (structures A1800 and A8340) have remarkably similar distributions and cumulative percentage curves in 2019. Sites 6 and 7 also were similar in the 2011 surveys and also relatively similar to site 8 (structure A4649) in 2011. Sites 9 and 10 (structures A4060 and A7650) were similar to one another in 2015, but site 9 was more similar to site 11 (structure A5817) in 2019. Site 13 (structures A4757/L0568) is likely too far removed from the other sites to have any similarity. The distributions at site 12 (structure A0767) historically have been remarkably similar during the various surveys (fig. 52) but unique from the other sites (fig. 71B); the cumulative percentage curve above 70 percent was at a higher elevation than several sites upstream, including site 9 (structure A4060) in 2010 and 2015 (fig. $71 B$ ). Site 8 (structure A4649) also has a wider range of elevations than other sites (figs. 21, 71A), indicated by the more gradual slope of the cumulative percent curve which often crosses the downstream sites at the lower percentages and crosses the two upstream sites at the upper percentages in the various surveys (fig. 71B).

Furthermore, the frequency distributions of the 2019 surveys compared to the previous surveys reveals additional differences that may be the result of streamflow conditions during the 2019 surveys (fig. 71). Whereas the frequency distributions generally were narrower in the 2015 survey than in either the 2010 or 2011 survey at each site with a higher percentage of survey-grid cells in a particular elevation range (fig. 71A), the distributions for the 2019 survey generally were slightly wider, similar to 2011 and indicative of a wider spread of elevations in the surveys at a given site. Similarly, whereas the narrower distributions in 2015 resulted in generally steeper accumulation curves, the 2019 accumulation curves were more similar to 2010 (figs. 71B). Accumulation curves that are steep indicate a channel bed with a narrower range of elevations (more level throughout the reach), whereas those that are less steep indicate a wider variation of elevations. Accumulation curves with "steps" indicate a channel with distinct groups of elevations, such as a thalweg on one side and a shallow area on the opposite side of the channel (such as structure A1800, figs. 6 and 7).

The size and shape of the frequency distributions through time also may be an indication of the type of river reach the site is located upon. Sites 6 and 7 are both on the same gentle bend in the river, and the similarities of the curve shapes may be indicative of the channel bend characteristics (figs. 7, 14, 71). Sites 11 and 12 also are on gentle river bends and have distributions curves with a similar shape to sites 6 and 7 (figs. 45, 52, 71). Site 13 also is on a gentle river bend, but the frequency distribution is somewhat unique (figs. 63, 71), likely because of the size and alignment of the piers at that site (fig. 62) result in a larger spread of elevations. Site 8 is just downstream from a substantial channel bend and also has a somewhat unique distribution curve (figs. 21, 71) that likely results from the channel bend and the size, alignment, and proximity of the various highway and railroad bridge piers at the site (figs. 19, 21, 71). Conversely, sites 9 and 10 are on a long, straight reach of the river and have narrow frequency distributions in all of the surveys (figs. 21, 32, 71).

Lastly, an examination of the dune features at the various sites with time is indicative of the different flow regimes during the various surveys. The dune features at the two upstream sites in the 2019 surveys were medium to large in size, whereas the dune features at all the other sites were small to medium in size. At structure A1800 (site 6, fig. 1), the dune features have been medium to very large for all the surveys at that site, almost regardless of the streamflow conditions (fig. 6; Huizinga, 2010, 2012, 2016). Whereas many of the surveys in the 2011 had a planar bed area and large to very large dune features indicative of high energy flow (Simons and Richardson, 1966), the 2019 surveys were more similar to the 2015 surveys, being filled throughout with mostly medium to small dune features and superimposed ripples (figs. 6, 13, $20,31,38,44,51,62)$. The largest dune features in the 2019 surveys were observed at structures A1800 (site 6, fig. 6) and A4757/L0568 (site 13, fig. 62). The smaller size and amplitude of the dune features compared to 2011 indicates less bedmaterial and bedload transport because of the lower streamflow values, whereas the larger size and amplitude of the dune features compared to 2015 indicates more bed-material and bedload transport (Simons and Richardson, 1966; Simon, Li and Associates, 1985).

\section{Size and Shape of Scour Holes}

Generally, every pier in the main channel area for which bathymetry could be obtained had some sort of scour hole, except those on banks or surrounded by riprap. However, the size and shape of these holes were different from one bridge to the next and occasionally even at the same bridge site. The factors affecting the size and shape of the pier scour holes have been discussed in previous survey reports (Huizinga, 2012, 2014, 2015, 2016, 2017a, 2020a, e), and in some cases, the frontal slope of the various scour holes has been determined. Frontal slopes were not computed for the sites in this (2019) study. However, the factors that affect the local pier scour equation in Arneson and others (2012), including the depth and velocity of approach flow, the width and nose shape of the pier, the angle of approach flow, and the condition and armoring of the channel bed, are discussed below.

For the various bridges in this study, streamflow velocities generally were greater in the deeper parts of the channel (the thalweg), and lower in the shallow parts of the channel, which is consistent with previous surveys. Of course, there were local exceptions, such as downstream from a spur dike where a local deep area may have had a low velocity (for example, figs. 19, 43, 57). Exceptions notwithstanding, the 
size of the scour holes at sites having more than one pier in the water was related to the depth and velocity of flow upstream from the pier in question, and consistent with the local pier scour equation in Arneson and others (2012). Deeper flow or higher velocity generally resulted in larger, deeper scour holes than shallow flow or lower velocities (figs. 15, 33, 46) in the absence of bedrock or riprap as a designed scour countermeasure (pier 3, fig. 22; pier 7, fig. 53). Similar findings have been observed during all the various studies using the MBMS in Missouri (Huizinga, 2010, 2011, 2012, 2014, 2015, 2016 , 2017a, 2020a, e).

Also consistent with the local pier scour equation in Arneson and others (2012), piers having wide or blunt noses resulted in larger, deeper scour holes than those having narrow, round, or sharp noses. Almost all the piers at the sites in the Kansas City area had some part of the foundation exposed to flow, whether the footing, seal course, or caisson. When the channel bed immediately upstream from a pier was above the top of a footing, the scour holes near that pier occasionally did not penetrate below the top of the footing (pier 3, figs. 44, 46); the footing effectively limited scour at these piers. However, when the upstream edge of the top of the footing was exposed, the substantial extra width of the footing tended to widen the scour hole (pier 3, figs. 6, 8; piers 5 and 6, figs. 31, 33; pier 2, figs. 44, 46; pier 7, figs. 51, 53; pier 2C, figs. 62, 64). Similar findings have been observed during the various studies using the MBMS in Missouri (Huizinga, 2010, 2011, 2012, 2014, 2015, 2016, 2017a, 2020a, e), particularly during the 2011 flood (Huizinga, 2012). The bents at structure A8340 (site 7) consist of cylindrical drilled shafts $10.5 \mathrm{ft}$ in diameter, and although the scour hole was somewhat smaller near the central bent (bent 4) compared to other sites (figs. 13, 15), the bent still had a scour hole that was about $17 \mathrm{ft}$ deep (table 6).

Several of the surveyed bridges had piers that were skewed to approach flow, resulting in asymmetric scour holes at those bridges: pier 3 of structure A1800 on Interstate 635 (fig. 6); pier 2 of structure A4649 on U.S. Highway 169 (fig. 20); the railroad bridge pier upstream from pier 6 of structure A4060 on State Route 9 (fig. 31); the main channel pylon of structure A7650 on Interstate 35 (fig. 38); and pier 2C of structure A4757 and pier 5 of structure L0568 on State Highway 291 (fig. 62). At all the structures except A7650, the scour hole was deeper and longer on the side of the pier with impinging flow, and some amount of deposition was on the leeward side, as typically has been observed at piers skewed to approach flow; however, at structure A7650, the scour hole was deeper and longer on the leeward side of the pier, possibly because of a deflection and contraction of flow caused by the protruding left bank at the bridge (figs. 38, 43). Although the velocities were not substantially affected by the constriction (fig. 43), the pylon and constriction may cause enough turbulence to pull sediment into suspension. At all the structures, the skew to approach flow is apparent in the velocity vectors (figs. 12, 26, 37, 43, 69). At structures A4757/L0568, the skew seems to be exacerbated by shear flow from the contraction of the right bank at the bridge (fig. 69).

\section{Effects of Riprap Blankets near Piers}

The main channel pylon of structure A7650 (site 10) has piles of rock surrounding it (fig. 38), and scour countermeasures in the form of a riprap blanket were placed around the central main channel pier of structures A4649 (site 8) and A0767 (site 12) between August and October of 2020. The riprap blankets at structures A4649 (site 8) and A0767 (site 12) were specifically designed to resist scour at those sites; it is unknown whether the rock around the main channel pylon of structure A7650 (site 10) was specifically designed, was an ad hoc placement of riprap to mitigate potential scour at that substructural bridge element, or simply was construction detritus. Nevertheless, the presence of these features had a substantial effect on the observed scour at these piers, particularly when compared to other piers at the same sites without such a feature, or when examining the survey results from before and after installation.

The main channel pylon of structure A7650 (site 10) seemed to be partially surrounded with piles of coarse material (figs. 38, 40, 1.6). Bridge plans do not indicate that these piles are a designed scour countermeasure. Some settling of the piles was observed in the 2019 survey compared to the previous surveys in 2015 and 2011 (figs. 41, 42) such that the bottom of the seal course was exposed by 5 to $10 \mathrm{ft}$ along the upstream face of the bridge (fig. 40). Nevertheless, these piles seem to effectively divert most of the scour near the pylon away from the pylon base. Scour immediately downstream from the pylon was substantial (fig. 38) but likely does not directly affect the stability of the pylon.

Pier 2 of structure A4696 on U.S. Highway 169 (site 8, fig. 1) had a riprap blanket installed between August and October of 2020 (figs. 27, 29) that was a minimum of $7.5 \mathrm{ft}$ thick per the bridge plans (Travis S. Stump, Missouri Department of Transportation, written commun., December 9, 2020; fig. 22). The survey after the installation clearly indicated the riprap blanket limited scour near pier 2 (figs. 29, 30). The top surface of the blanket is very irregular, partly because of the size of riprap stones used (figs. 22, 1.4), and seemed to have a depression next to the pier nose that seemed to penetrate the top of the blanket (fig. 22), which may have been the result of back-filling the existing scour hole or other low spot when the blanket was installed.

Pier 7 of structure A0767 on Interstate 435 (site 12, fig. 1) has had a long history of substantial scour (Huizinga, 2010, 2012, 2016). An enlarged seal course and riprap blanket were installed between August and October of 2020 (figs. 53, 58, 59) that was a minimum of $7.5 \mathrm{ft}$ thick per the bridge plans (Travis S. Stump, Missouri Department of Transportation, written commun., December 16, 2020; fig. 53). The survey after the installation also clearly indicated the riprap blanket limited scour near pier 7 (figs. 58, 59). As at site 8, the top surface of the blanket is very irregular, partly because of the size of riprap stones used (figs. 53, 1.9), and had a substantial depression next to the pier nose that seemed to penetrate the 
top of the blanket (figs. 53, 1.9), which may have been the result of back-filling the existing scour hole or other low spot when the blanket was installed.

\section{Summary and Conclusions}

Bathymetric and velocimetric data were collected by the U.S. Geological Survey, in cooperation with the Missouri Department of Transportation, near 9 bridges at 8 highway crossings of the Missouri River near Kansas City, Missouri, on August 13-14, 2019. A multibeam echosounder mapping system was used to obtain channel-bed elevations for areas ranging from 1,550 to 1,660 feet longitudinally and generally extending across the active channel from bank to bank in the Missouri River during moderate flood-flow conditions. Two additional, limited surveys were completed in cooperation with Clarkson Construction near the central main channel pier of two of the sites in August and October 2020, before and after installation of scour countermeasures near these piers. These surveys document the channel-bed conditions and velocity distribution at the time of the surveys and provide characteristics of scour holes that may be useful in the development of predictive guidelines or equations for scour holes. These data also may be used by the Missouri Department of Transportation as a moderate flow assessment of the bridges for stability and integrity issues with respect to bridge scour during floods.

The estimated uncertainty for the bathymetric surface of each survey area was computed as an estimate of the accuracy to be expected for each point with all relevant sources of error taken into account. An analysis of the surveys indicated that more than 99 percent of the bathymetric data at all the sites have an uncertainty of less than 0.50 foot (ft), and more than 96 percent of the channel-bed elevations at the sites have an uncertainty of less than $0.25 \mathrm{ft}$.

At all the surveyed bridges, a variety of fluvial geomorphic features were detected in the channel, ranging from small ripples to large dunes that indicate moderate transport of bedload. Rock outcrops also were detected along one bank at several sites where the alluvial material of the channel bed had been washed away. Bathymetric data were collected around every pier that was in water, except around the nose of one pier that is surrounded by a persistent debris raft. Scour holes were present at most piers for which bathymetry could be obtained, except those on banks or surrounded by riprap. The observed scour holes at the surveyed bridges were examined with respect to shape and depth.

All of the bridge sites in this study were previously surveyed. Comparisons between bathymetric surfaces from the previous surveys (in March 2010, during the 2011 flood, and in June 2015) and those of this study do not indicate any consistent correlation in channel-bed elevations with streamflow conditions. Most of the surveys in the current (2019) study happened during a trough between flood rises during generally higher summer streamflows, and the measured streamflow generally was the second lowest compared to previous surveys; however, a simplified assumption of equal to lesser magnitude scour with lower streamflow did not consistently prove to be true, particularly with respect to the depth of observed scour near the piers when compared to results from the 2011 flood. Streamflow during the 2019 surveys ranged from 33 to 47 percent of the 2011 streamflow, and watersurface elevations were about 6.6 to $13.4 \mathrm{ft}$ lower in 2019 than in 2011. Streamflow during the 2019 surveys ranged from about 1.2 to 1.5 times greater than the 2015 streamflow, and water-surface elevations were 1.5 to $5.1 \mathrm{ft}$ higher in 2019 than in 2015; however, the average difference between the bathymetric surfaces varied from 0.13 to $4.17 \mathrm{ft}$ lower in 2019 than 2015, and varied from $0.22 \mathrm{ft}$ higher to $4.91 \mathrm{ft}$ lower in 2019 than 2011. The predominant overall scour observed between the various surveys implies the channel bed in the 2019 surveys might have been rebounding from more substantial scour caused by the high streamflow earlier in March and June 2019, which was the highest streamflow since 1993.

A local spatial minimum average channel-bed elevation at structure A7650 (site 10) compared to adjacent sites observed in previous surveys may indicate this site is at or near a local feature that controls sediment deposition and scour. The feature may be a combination of the minor constriction at the site and being near the downstream end of the relatively straight reach of river; furthermore, the average channel-bed elevation values and the distribution of channel-bed elevations imply that sediment unable to deposit near structure A7650 may be flushed downstream and deposited at the next downstream site, structure A5817 (site 11).

Pier size and nose shape also had a substantial effect on the size of the scour hole observed at a given pier. Many of the piers at the Kansas City area bridges have wide or blunt noses caused by exposed footings, seal courses, or caissons, which resulted in larger, deeper scour holes at most piers. Several of the structures had piers that were skewed to primary approach flow, and at most of the structures, the scour hole was deeper and longer on the side of the pier with impinging flow, with some amount of deposition on the leeward side, as typically has been observed at piers skewed to approach flow. However, at structure A7650 (site 10), the scour hole was deeper and longer on the leeward side of the pier, possibly because of a deflection and contraction of flow caused by a protrusion of the corresponding bank at the bridge.

Two piers had scour countermeasures in the form of a riprap blanket installed between August and October 2020. Survey results from before and after installation of these countermeasures show these features had a substantial effect on mitigating the observed scour at these piers, particularly when compared to other piers at other sites without such a feature. 


\section{References Cited}

Applanix Corporation, 2017, POSPac MMS GNSS-inertial tools software (rev. 15): Richmond Hill, Ontario, Canada, Applanix Corporation, PUBS-MAN-001768, 246 p.

Arneson, L.A., Zevenbergen, L.W., Lagasse, P.F., and Clopper, P.E., 2012, Evaluating scour at bridges (5th ed.): U.S. Federal Highway Administration Publication FHWAHIF-12-003, Hydraulic Engineering Circular no.18, 340 p., accessed March 9, 2021, at https://www.fhwa.dot.gov/ engineering/hydraulics/pubs/hif12003.pdf.

Becker, L.D., 1994, Investigation of bridge scour at selected sites on Missouri streams: U.S. Geological Survey WaterResources Investigations Report 94-4200, 40 p. [Also available at https://doi.org/10.3133/wri944200.]

Calder, B.R., and Mayer, L.A., 2003, Automatic processing of high-rate, high-density multibeam echosounder data: Geochemistry, Geophysics, Geosystems $\left(\mathrm{G}^{3}\right)$, v. 4, no. 6, 22 p. [Also available at https://doi.org/10.1029/2002GC000486.]

Densmore, B.K., Strauch, K.R., and Dietsch, B.J., 2013, Hydrographic surveys of the Missouri and Yellowstone Rivers at selected bridges and through Bismarck, North Dakota, during the 2011 flood: U.S. Geological Survey Scientific Investigations Report 2013-5087, 59 p. [Also available at https://doi.org/10.3133/sir20135087.]

Dietsch, B.J., Densmore, B.K., and Strauch, K.R., 2014, Hydrographic surveys at selected highway bridges crossing the Missouri River using a multibeam echosounder, 2011: U.S. Geological Survey Scientific Investigations Report 2014-5062, 53 p. [Also available at https://doi.org/10.3133/sir20145062.]

Esri, 2020, ArcGIS: Esri software, accessed February 2020 at https://www.esri.com/software/arcgis/.

Gilbert, G.K., and Murphy, E.C., 1914, The transportation of debris by running water: U.S. Geological Survey Professional Paper 86, 263 p. [Also available at https://doi.org/10.3133/pp86.]

Huizinga, R.J., 2010, Bathymetric surveys at highway bridges crossing the Missouri River in Kansas City, Missouri, using a multibeam echo sounder, 2010: U.S. Geological Survey Scientific Investigations Report 2010-5207, 61 p. [Also available at https://doi.org/10.3133/sir20105207.]

Huizinga, R.J., 2011, Bathymetric surveys at highway bridges crossing the Missouri and Mississippi Rivers near St. Louis, Missouri, 2010: U.S. Geological Survey Scientific Investigations Report 2011-5170, 75 p. [Also available at https://doi.org/10.3133/sir20115170.]
Huizinga, R.J., 2012, Bathymetric and velocimetric surveys at highway bridges crossing the Missouri River in and into Missouri during summer flooding, July-August 2011: U.S. Geological Survey Scientific Investigations Report 2012-5204, 166 p. [Also available at https://doi.org/10.3133/sir20125204.]

Huizinga, R.J., 2013, Results of repeat bathymetric and velocimetric surveys at the Amelia Earhart Bridge on U.S. Highway 59 over the Missouri River at Atchison, Kansas, 2009-2013: U.S. Geological Survey Scientific Investigations Report 2013-5177, 50 p. [Also available at https://doi.org/10.3133/sir20135177.]

Huizinga, R.J., 2014, Bathymetric and velocimetric surveys at highway bridges crossing the Missouri River between Kansas City and St. Louis, Missouri, April-May, 2013: U.S. Geological Survey Scientific Investigations Report 2014-5116, 79 p. [Also available at https://doi.org/10.3133/sir20145116.]

Huizinga, R.J., 2015, Bathymetric and velocimetric surveys at highway bridges crossing the Missouri and Mississippi Rivers on the periphery of Missouri, June 2014: U.S. Geological Survey Scientific Investigations Report 2015-5048, 81 p. [Also available at https://doi.org/10.3133/sir20155048.]

Huizinga, R.J., 2016, Bathymetric and velocimetric surveys at highway bridges crossing the Missouri River near Kansas City, Missouri, June 2-4, 2015: U.S. Geological Survey Scientific Investigations Report 2016-5061, 93 p. [Also available at https://doi.org/10.3133/sir20165061.]

Huizinga, R.J., 2017a, Bathymetric and velocimetric surveys at highway bridges crossing the Missouri and Mississippi Rivers near St. Louis, Missouri, May 23-27, 2016: U.S. Geological Survey Scientific Investigations Report 2017-5076, 102 p. [Also available at https://doi.org/10.3133/sir20175076.]

Huizinga, R.J., 2017b, Bathymetry and velocity data from surveys at highway bridges crossing the Missouri and Mississippi Rivers near St. Louis, Missouri, October 2008 through May 2016: U.S. Geological Survey data release, https://doi.org/10.5066/F71C1VCC.

Huizinga, R.J., 2020a, Bathymetric and velocimetric surveys at highway bridges crossing the Missouri River between Kansas City and St. Louis, Missouri, May 22-31, 2017: U.S. Geological Survey Scientific Investigations Report 2020-5018, 104 p. [Also available at https://doi.org/10.3133/sir20205018.]

Huizinga, R.J., 2020b, Bathymetry and velocity data from surveys at highway bridges crossing the Missouri River in Kansas City, Missouri, March 2010 through May 2017: U.S. Geological Survey data release, https://doi.org/10.5066/P9L6GW57. 
Huizinga, R.J., 2020c, Bathymetry and velocity data from surveys at highway bridges crossing the Missouri River between Kansas City and St. Louis, Missouri, January 2010 through May 2017: U.S. Geological Survey data release, https://doi.org/10.5066/P94M4US7.

Huizinga, R.J., 2020d, Bathymetry and velocity data from surveys at highway bridges crossing the Missouri and Mississippi Rivers on the periphery of Missouri, December 2008 through August 2018: U.S. Geological Survey data release, https://doi.org/10.5066/P9WDI9YF.

Huizinga, R.J., 2020e, Bathymetric and velocimetric surveys at highway bridges crossing the Missouri and Mississippi Rivers on the periphery of Missouri, July-August 2018: U.S. Geological Survey Scientific Investigations Report 2020-5088, 100 p. [Also available at https://doi.org/10.3133/sir20205088.]

Huizinga, R.J., 2021, Bathymetry and velocity data from surveys at highway bridges crossing the Missouri River in Kansas City, Missouri, in August 2019, August 2020, and October 2020: U.S. Geological Survey data release, https://doi.org/10.5066/P96TX8AE.

Huizinga, R.J., Elliott, C.M., and Jacobson, R.B., 2010, Bathymetric and velocimetric survey and assessment of habitat for pallid sturgeon on the Mississippi River in the vicinity of the proposed Interstate 70 Bridge at St. Louis, Missouri: U.S. Geological Survey Scientific Investigations Report 2010-5017, 28 p. [Also available at https://doi.org/10.3133/sir20105017.]

Huizinga, R.J., and Rydlund, P.H., Jr., 2004, Potentialscour assessments and estimates of scour depth using different techniques at selected bridge sites in Missouri: U.S. Geological Survey Scientific Investigations Report 2004-5213, 42 p. [Also available at https://doi.org/10.3133/sir20045213.]

HYPACK, Inc., 2018, HYPACK hydrographic survey software user manual: Middletown, Conn., HYPACK, Inc., 2434 p., accessed February 2020 at https://www.h ypack.com/file\%20library/resource\%20library/manuals/ 2018/2018-hypack-user-manual.pdf.

International Hydrographic Organization, 2008, IHO standards for hydrographic surveys (5th ed.): Monaco, International Hydrographic Bureau, Special publication no. 44, 27 p.

Mueller, D.S., Wagner, C.R., Rehmel, M.S., Oberg, K.A., and Rainville, F., 2013, Measuring discharge with acoustic Doppler current profilers from a moving boat (ver. 2.0, December 2013): U.S. Geological Survey Techniques and Methods, book 3, chap. A22, 95 p. [Also available at https://doi.org/10.3133/tm3A22.]
National Marine Electronics Association, 2002, NMEA 0183-Standard for interfacing marine electronic devices (ver. 3.01). National Marine Electronics Association, 88 p.

Parsons, D.R., Jackson, P.R., Czuba, J.A., Engel, F.L., Rhoads, B.L., Oberg, K.A., Best, J.L., Mueller, D.S., Johnson, K.K., and Riley, J.D., 2013, Velocity Mapping Toolbox (VMT) - A processing and visualization suite for movingvessel ADCP measurements: Earth Surface Processes and Landforms, v. 38, no. 11, p. 1244-1260. [Also available at https://doi.org/10.1002/esp.3367.]

Riverscapes Consortium, 2020, Geomorphic change detection software: Riverscapes Consortium, accessed December 2020 at http://gcd.riverscapes.xyz/.

Rydlund, P.H., Jr., 2009, Real-time river channel-bed monitoring at the Chariton and Mississippi Rivers in Missouri, 2007-09: U.S. Geological Survey Scientific Investigations Report 2009-5254, 27 p. [Also available at https://doi.org/10.3133/sir20095254.]

Simons, D.B., and Richardson, E.V., 1966, Resistance to flow in alluvial channels: U.S. Geological Survey Professional Paper 422-J, 61 p. [Also available at https://doi.org/10.3133/pp422J.]

Simon, Li and Associates, 1985, Seasonal effects of river stage-discharge relations at selected gages, Final Report: Fort Collins, Colo., prepared for U.S. Army Corps of Engineers, Contract No. DACW43-85-D-0017, 96 p.

U.S. Army Corps of Engineers, 2004, Upper Mississippi River System flow frequency study, appendix E: Rock Island, Ill., U.S. Army Corps of Engineers, accessed December 2020 at https://www.mvr.usace.army.mil/Portals/48/docs/FRM/ UpperMissFlowFreq/App.\%20E\%20Kansas\%20City \% 20Dist.\%20Hydrology_Hydraulics.pdf.

U.S. Army Corps of Engineers, 2013, Engineering and design-Hydrographic surveying: Washington D.C., U.S. Army Corps of Engineers, manual no. EM 1110-2-1003, 560 p.

U.S. Geological Survey, 2020, USGS water data for the Nation: U.S. Geological Survey National Water Information System database, accessed December 2020 at https://doi.org/10.5066/F7P55KJN.

U.S. Geological Survey, 2021, USGS Streamgage Statistics for station 06893000: U.S. Geological Survey WaterWatch toolkit, accessed April 2021 at https://waterwatch.usgs.gov/ index.php?sno $=06893000 \& \mathrm{ds}=\mathrm{dv} 01 \mathrm{~d}$ _por\&btnGo$=$ GO\&m=sitempnn. 


\section{Glossary}

bent $A$ vertical, load-bearing, intermediate bridge substructure unit between the ends of a bridge used to support the bridge at intermediate intervals, typically consisting of two or more piles (referred to as a "pile bent") or columns, each supported by an individual footing, pile, or drilled shaft.

caisson An older type of bridge foundation consisting of a watertight retaining structure used as the foundation of a bridge pier, constructed in such a way that the water can be pumped out, keeping the work environment dry while the ground under the caisson is excavated and the caisson "sunk" into final position below the ground line. Upon reaching its final position, the caisson is backfilled with sand or gravel for added weight and stability.

cap The upper or bearing part of a bridge pier or bent, usually made of concrete or hard stone and designed to distribute concentrated loads from the bridge superstructure evenly over the columns of the pier or bent.

cofferdam A temporary retaining structure used in pier and pylon construction to retain water and support the sides of an excavation where water is present. A cofferdam generally consists of vertical sheet piling around the perimeter of a bracing system and a bottom seal course. Once sealed, the water can be pumped out, keeping the work environment dry while the footing, columns, and other substructural elements are built.

column The primary part of a bridge bent, pier, or pylon used to convey the load of the bridge superstructure to the foundation.

drilled shaft A cylindrical shaft that is drilled into the ground as a bridge foundation, typically extending through the alluvial material into underlying rock and filled with reinforced concrete.

footing A part of the foundation of a bridge bent, pier, or pylon used to transmit the load from the column to the ground, either directly or indirectly through piles or drilled shafts. pedestal A transitional element occasionally used in a bridge pier or pylon, typically found between the column and a footing or caisson.

pier A vertical, load-bearing, intermediate bridge substructure unit between the ends of a bridge used to support the bridge at intermediate intervals, consisting of a single column or shaft, or multiple columns connected with a solid web, and generally supported by a single footing.

pile A long, narrow cylinder or beam made of wood, metal, or concrete used as part of the foundation of a bridge, typically driven into the ground from above and integrated into a seal course of a pier, or the cap of a pile bent.

pylon A tower-like vertical, load-bearing substructural unit that usually supports the cables of a suspension bridge or a cable-stayed bridge. A pylon typically extends above the bridge superstructure.

seal course The base of a newer type of bridge foundation, created when a cofferdam used to build the foundation is "sealed" with concrete at the underwater ground level to prevent water from entering the cofferdam from below.

substructure The part of a bridge that supports the superstructure and transmits the load of the superstructure and deck to the ground through the foundations.

superstructure The part of a bridge that supports the bridge deck, and connects one substructural element to another and thereby transmits the load of the deck and anything on the deck to the substructure.

water year A continuous 12-month period selected to present data relative to hydrologic or meteorological phenomena during which a complete annual hydrologic cycle normally occurs. The water year used by the U.S. Geological Survey runs from October 1 through September 30, and is designated by the year in which it ends. 


\section{Appendix 1. Shaded Triangulated Irregular Network Images of the Channel and Side of Pier for Each Surveyed Pier}

Shaded triangulated irregular network images of the channel and side of pier were prepared for each surveyed pier at structure A1800 (fig. 1.1), structure A8340 (fig. 1.2), structure A4649 (figs. 1.3, 1.4), structure A4060 (fig. 1.5), structure A7650 (fig. 1.6), structure A5817 (fig. 1.7), structure A0767 (figs. 1.8, 1.9), and structures A4757 and L0568 (fig. 1.10). 

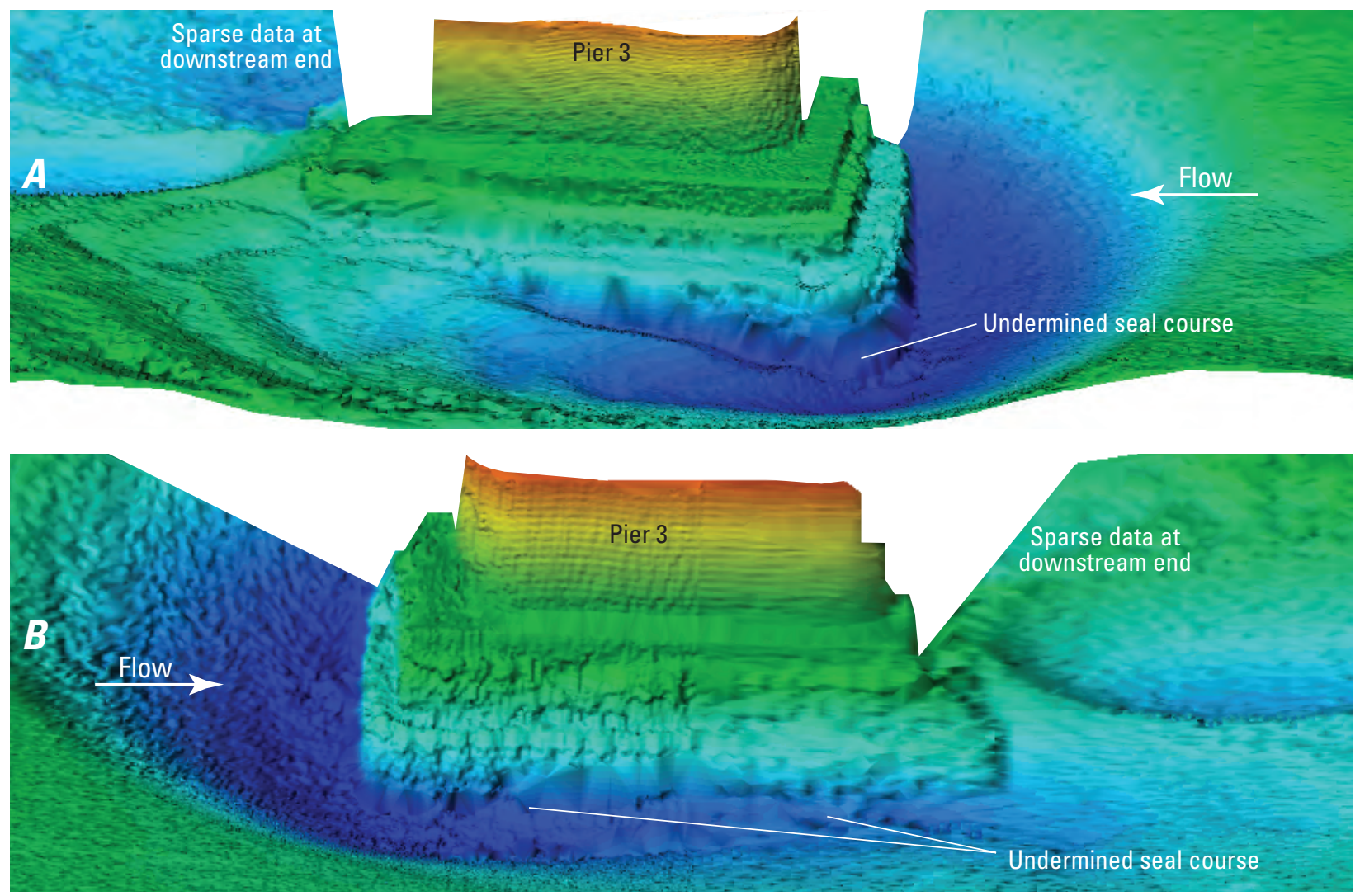

Pier 2

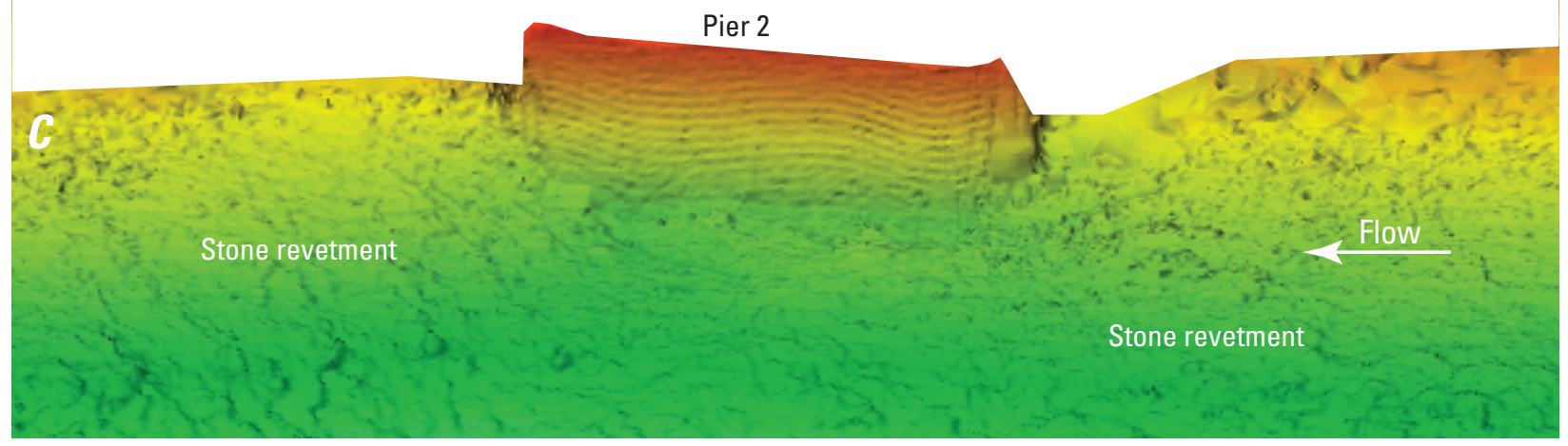

EXPLANATION

Elevation of point, in feet

above the North American

Vertical Datum of 1988

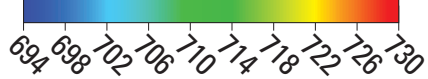

Figure 1.1. Shaded triangulated irregular network visualization of the channel bed and main channel piers of structure A1800 on Interstate 635 over the Missouri River in Kansas City, Missouri. $A$, left (northeast) side of pier 3. $B$, right (southwest) side of pier 3. $C$, left (northeast) side of pier 2. 


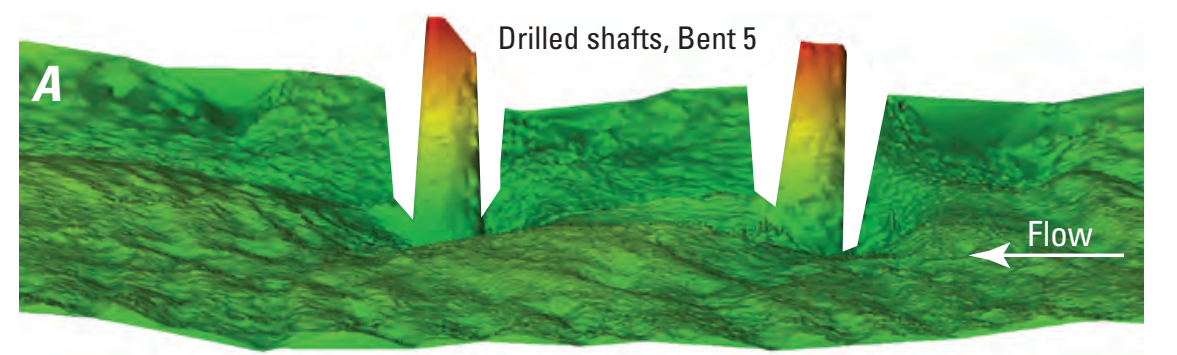

\section{EXPLANATION}

Elevation, in feet above the North American

\section{Vertical Datum of 1988}
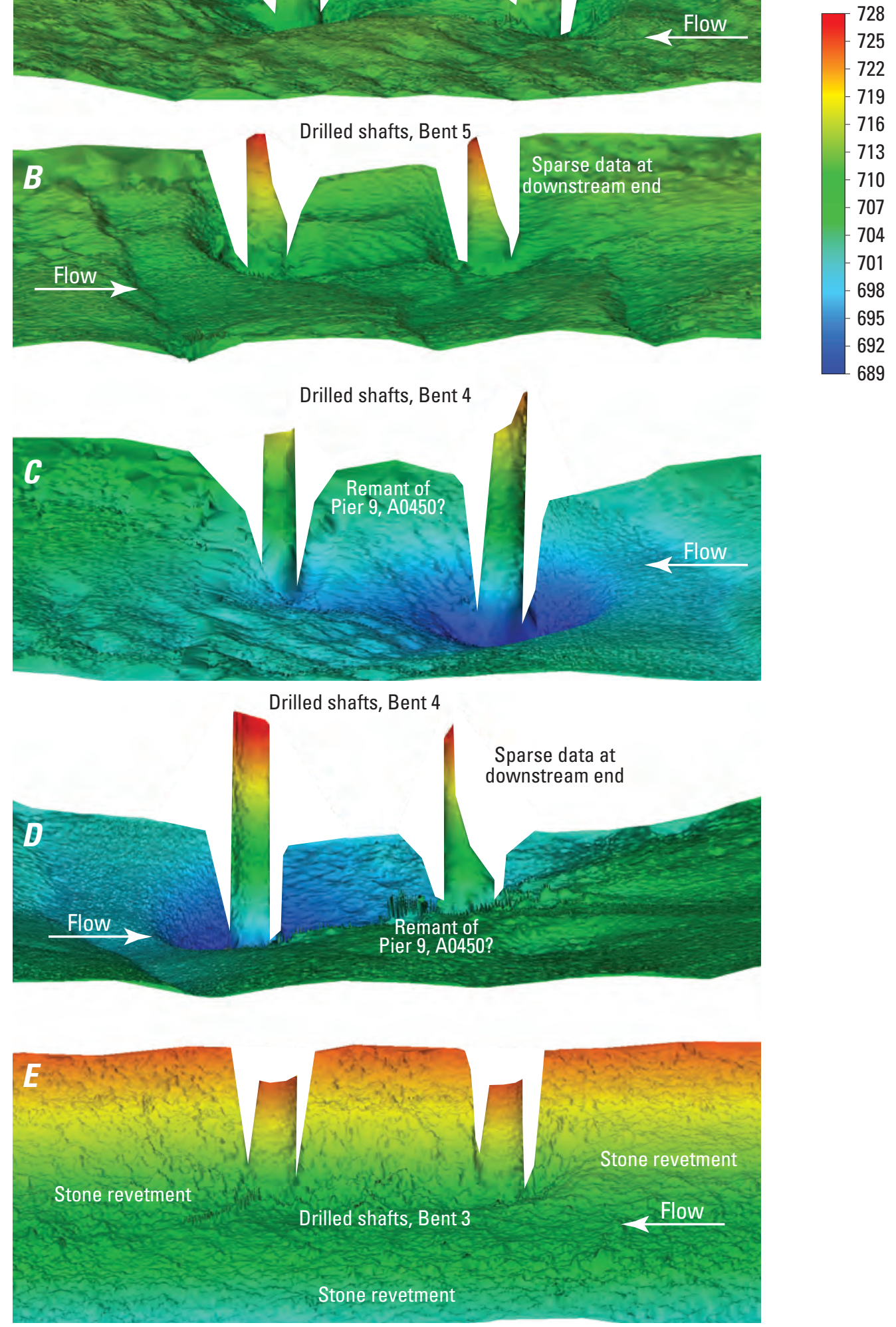

Figure 1.2. Shaded triangulated irregular network visualization of the channel bed and main channel bents of structure A8340 on U.S. Highway 69 over the Missouri River in Kansas City, Missouri. A, left (north) side of bent 5. $B$, right (south) side of bent 5 . $C$, left (north) side of bent 4. $D$, right (south) side of bent 4 . $E$, left (north) side of bent 3. 

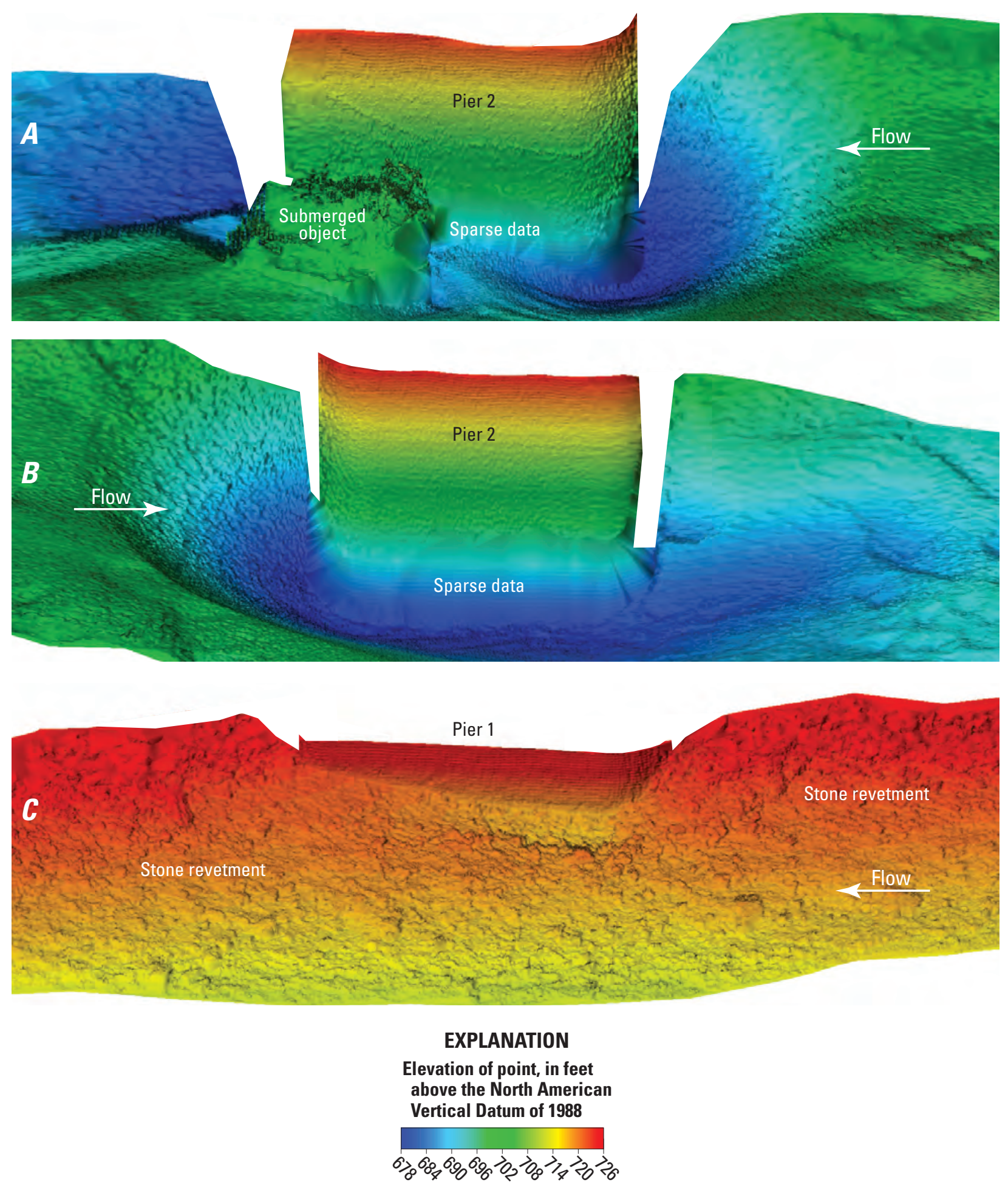

Figure 1.3. Shaded triangulated irregular network visualization of the channel bed and main channel piers of structure A4649 on U.S. Highway 169 crossing the Missouri River in Kansas City, Missouri, on August 13, 2019, before installation of scour countermeasures. $A$, left (northwest) side of pier 2. B, right (southeast) side of pier 2. C, left (northwest) side of pier 1. 

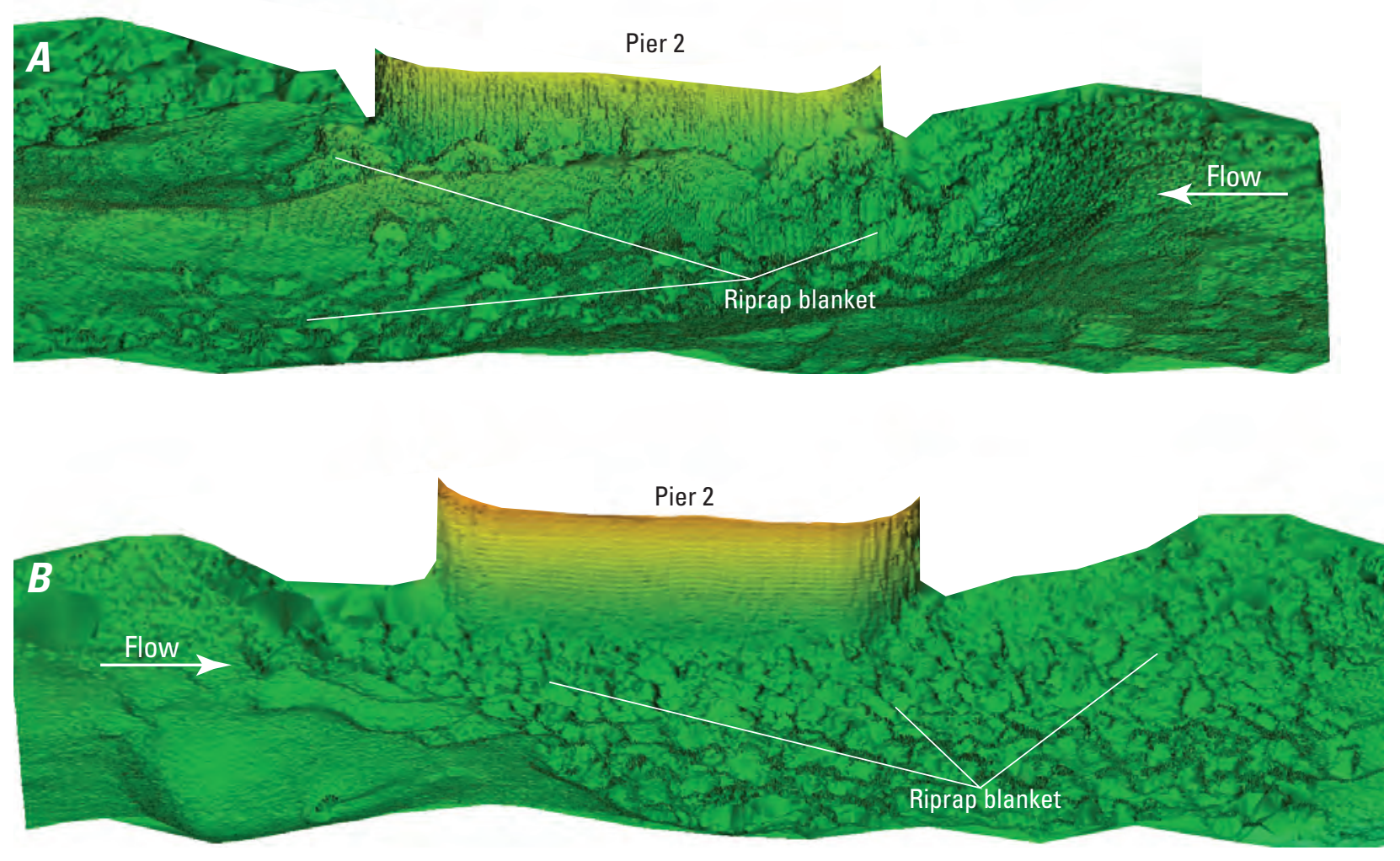

\section{EXPLANATION}

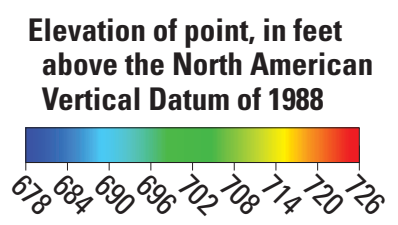

Figure 1.4. Shaded triangulated irregular network visualization of the channel bed and main channel pier 2 of structure A4649 on U.S. Highway 169 crossing the Missouri River in Kansas City, Missouri, on October 23, 2020, after installation of scour countermeasures. $A$, left (northwest) side of pier 2. B, right (southeast) side of pier 2. 

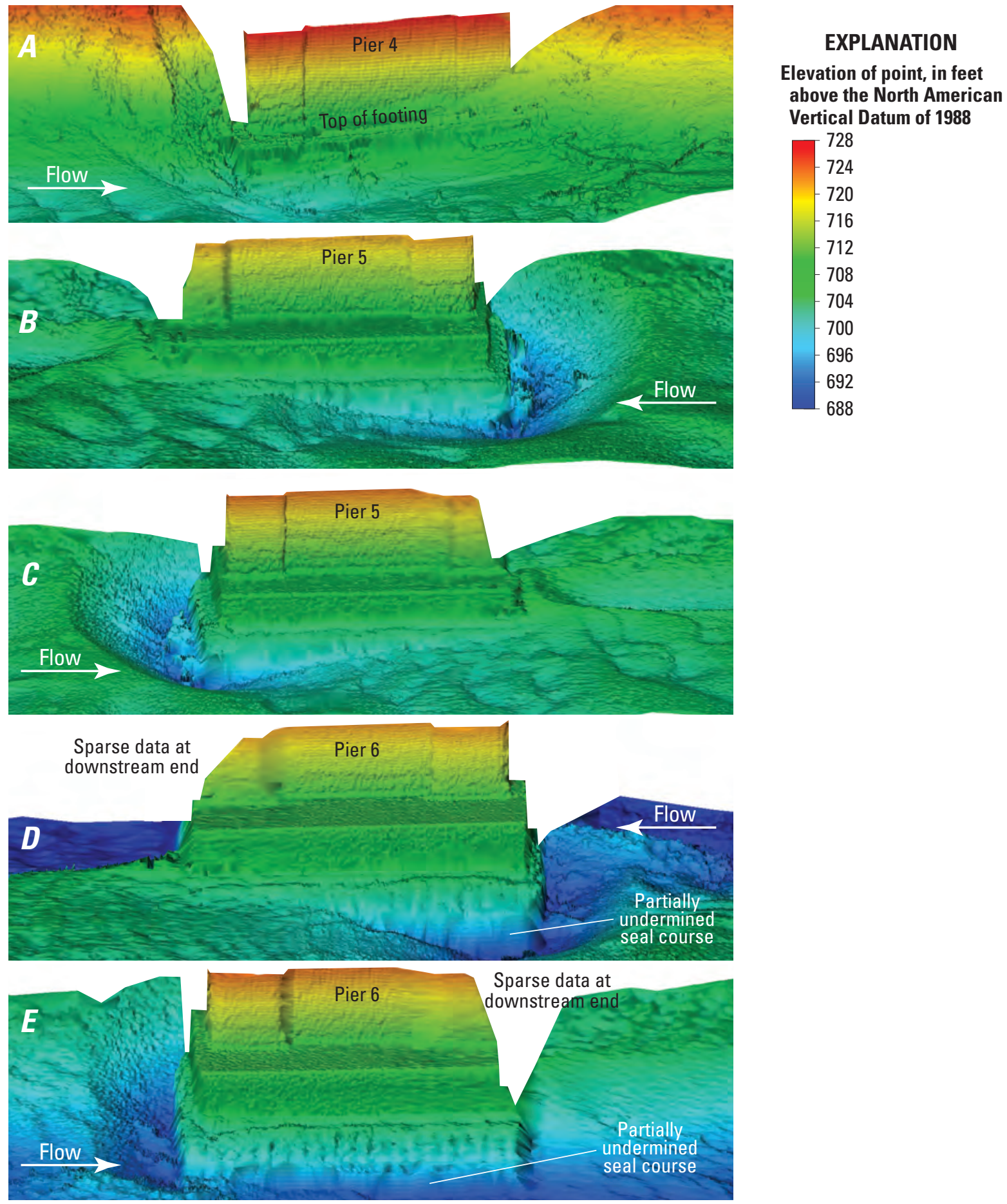

Figure 1.5. Shaded triangulated irregular network visualization of the channel bed and main channel piers of structure A4060 on State Highway 9 over the Missouri River in Kansas City, Missouri. A, right (southeast) side of pier 4. B, left (northwest) side of pier 5. C, right (southeast) side of pier 5. D, left (northwest) side of pier 6. E, right (southeast) side of pier 6 . 

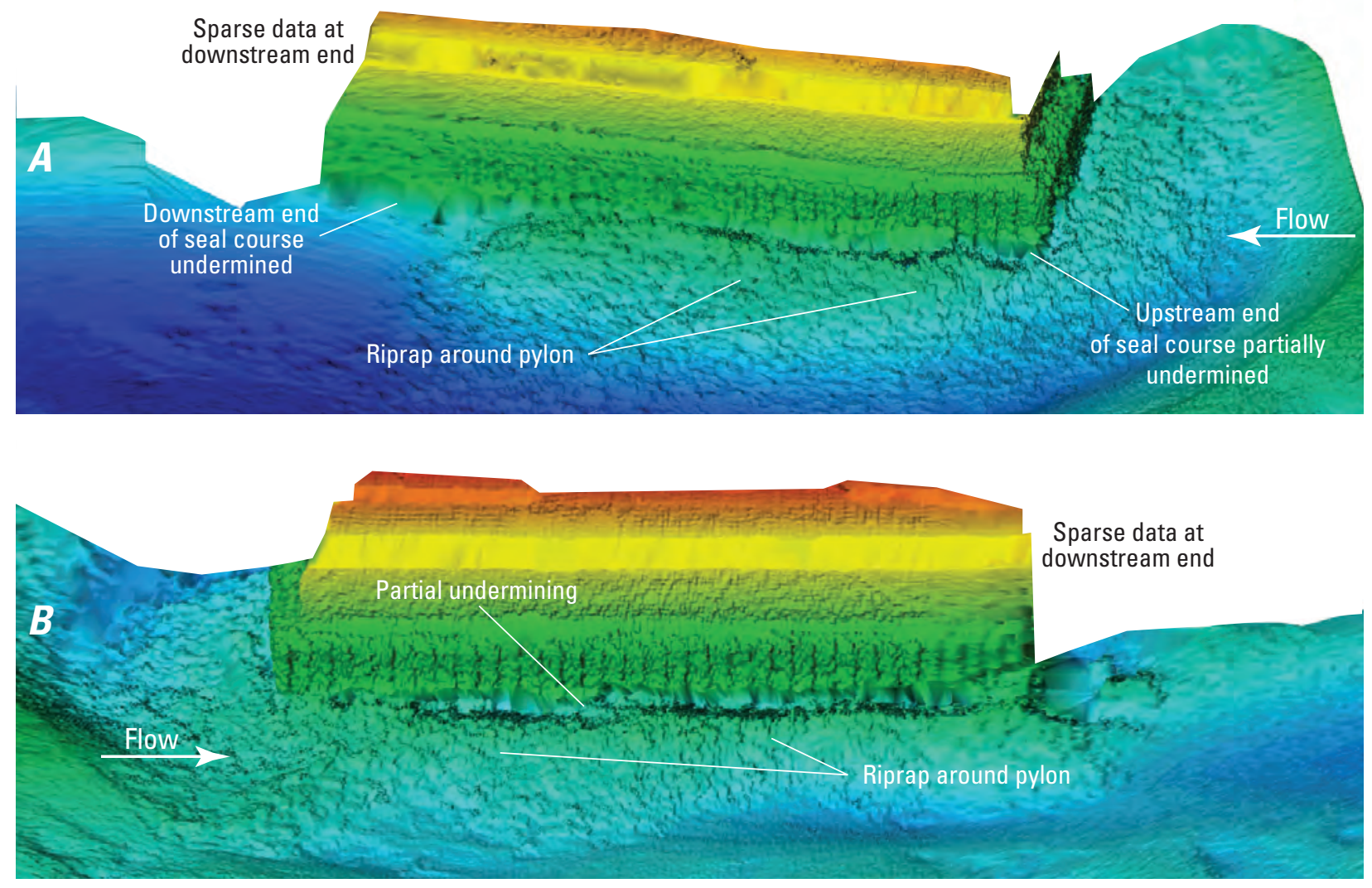

\section{EXPLANATION}

Elevation of point, in feet above the North American Vertical Datum of 1988

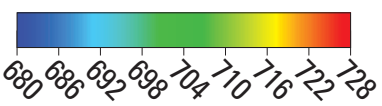

Figure 1.6. Shaded triangulated irregular network visualization of the channel bed and main channel pylon of structure A7650 on Interstate 35 over the Missouri River in Kansas City, Missouri. $A$, left (northwest) side. $B$, right (southeast) side. 


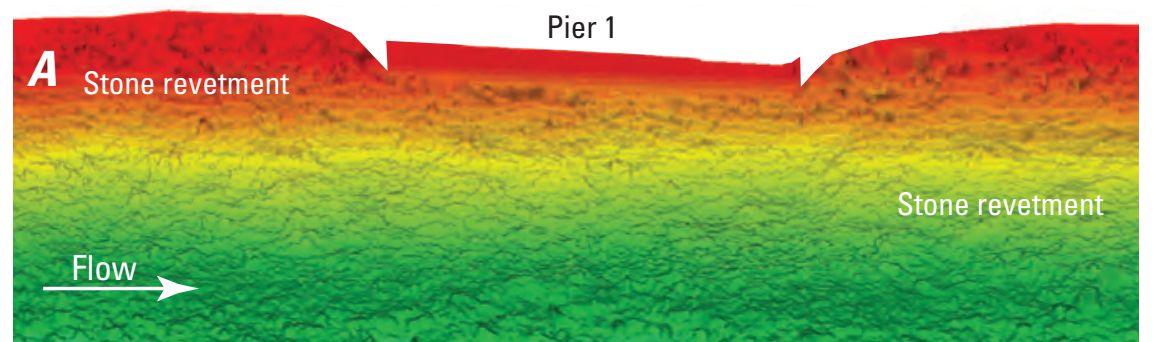

\section{EXPLANATION \\ Elevation of point, in feet above the North American} Vertical Datum of 1988
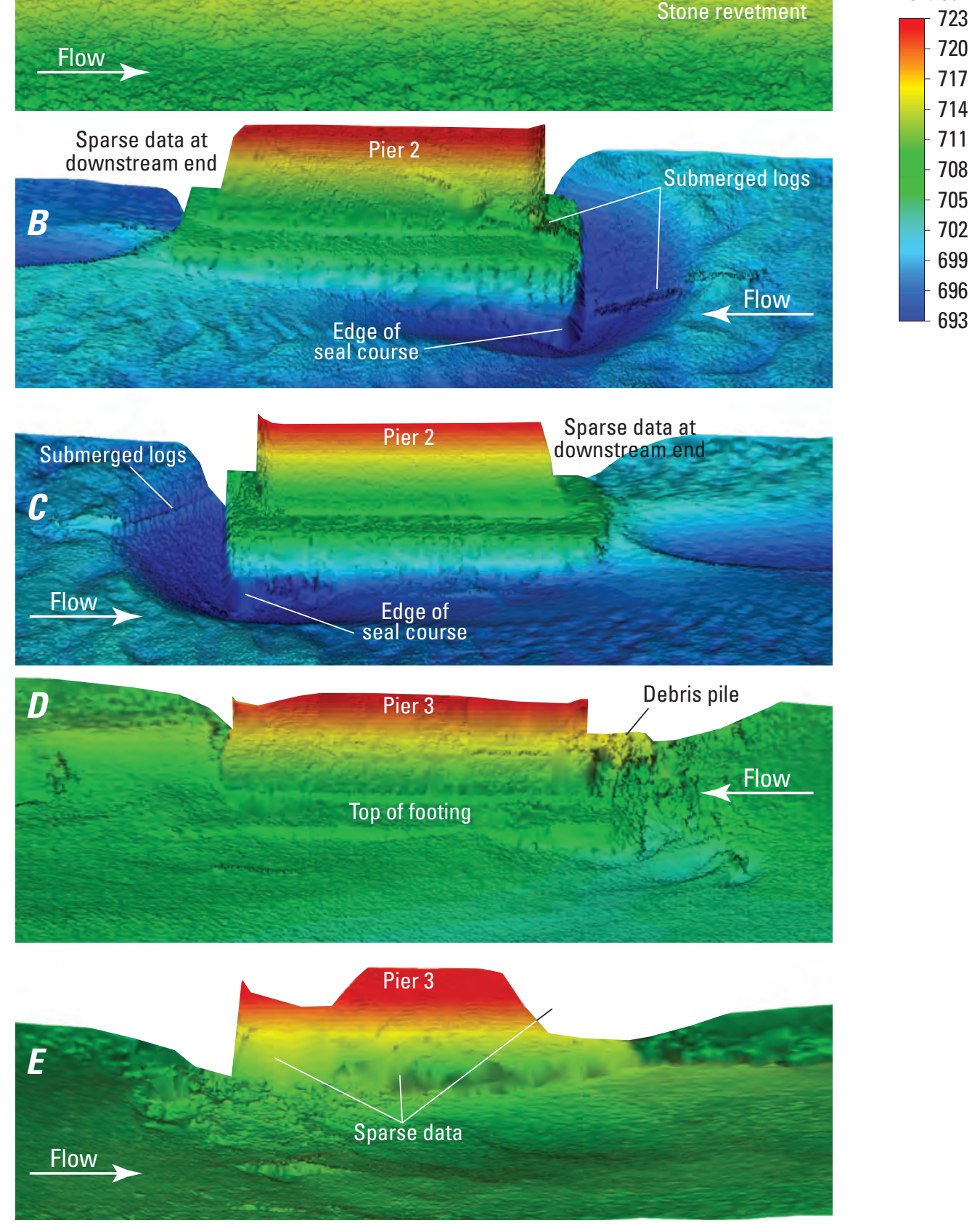

Figure 1.7. Shaded triangulated irregular network visualization of the channel bed and main channel piers of structure A5817 on State Highway 269 over the Missouri River in Kansas City, Missouri. A, left (northwest) side of pier 2. B, right (southeast) side of pier 2. C, left (northwest) side of pier 3. D, right (southeast) side of pier 3. 


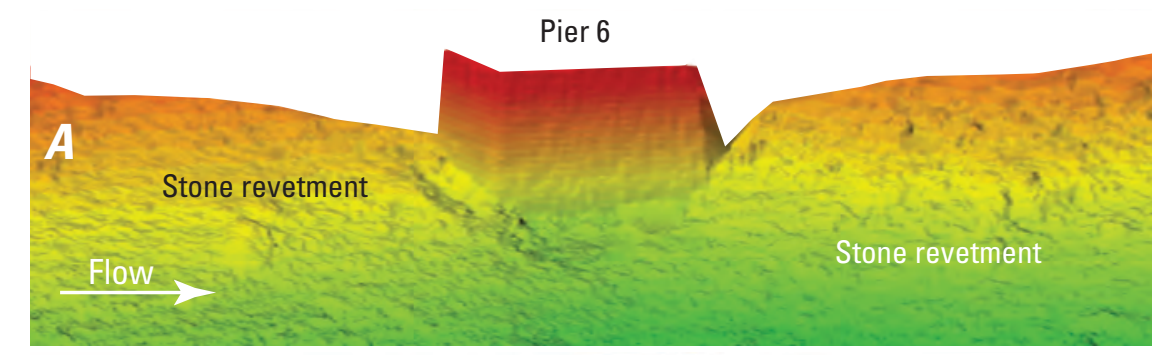

\author{
EXPLANATION \\ Elevation of point, in feet \\ above the North American \\ Vertical Datum of 1988
}
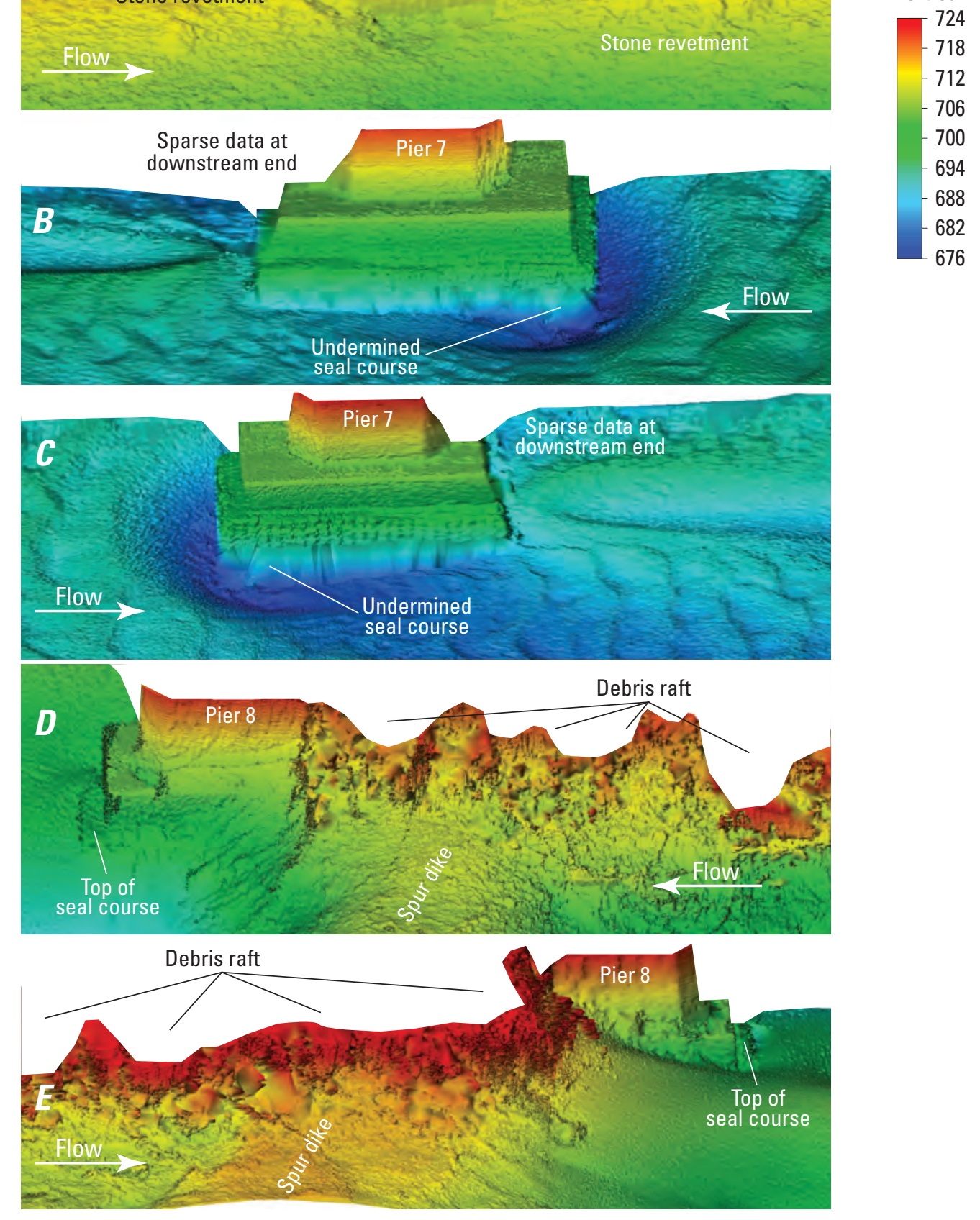

Figure 1.8. Shaded triangulated irregular network visualization of the channel bed and main channel piers of structure A0767 on Interstate 435 over the Missouri River in Kansas City, Missouri, on August 14, 2019, before installation of scour countermeasures. $A$, right (south) side of pier 6 . $B$, left (north) side of pier 7. $C$, right (south) side of pier 7 . $D$, left (north) side of pier 8 . E, right (south) side of pier 8. 
Pier 7
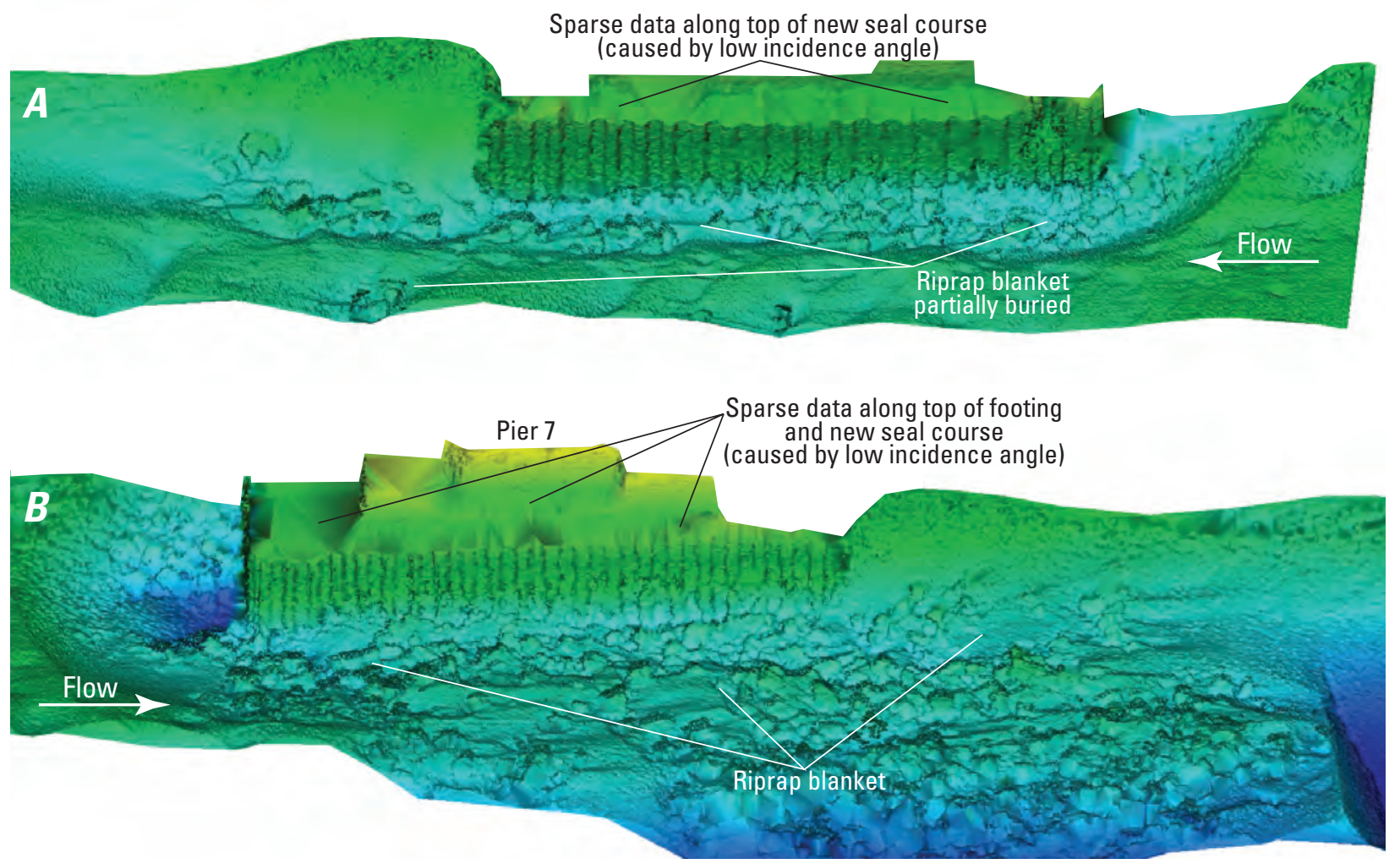

EXPLANATION

Elevation of point, in feet above the North American Vertical Datum of 1988

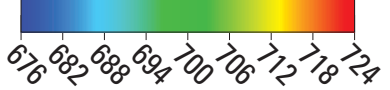

Figure 1.9. Shaded triangulated irregular network visualization of the channel bed and main channel pier 7 of structure A0767 on Interstate 435 over the Missouri River in Kansas City, Missouri, on October 23, 2020, after installation of scour countermeasures. $A$, left (north) side of pier 7. $B$, right (south) side of pier 7 . 

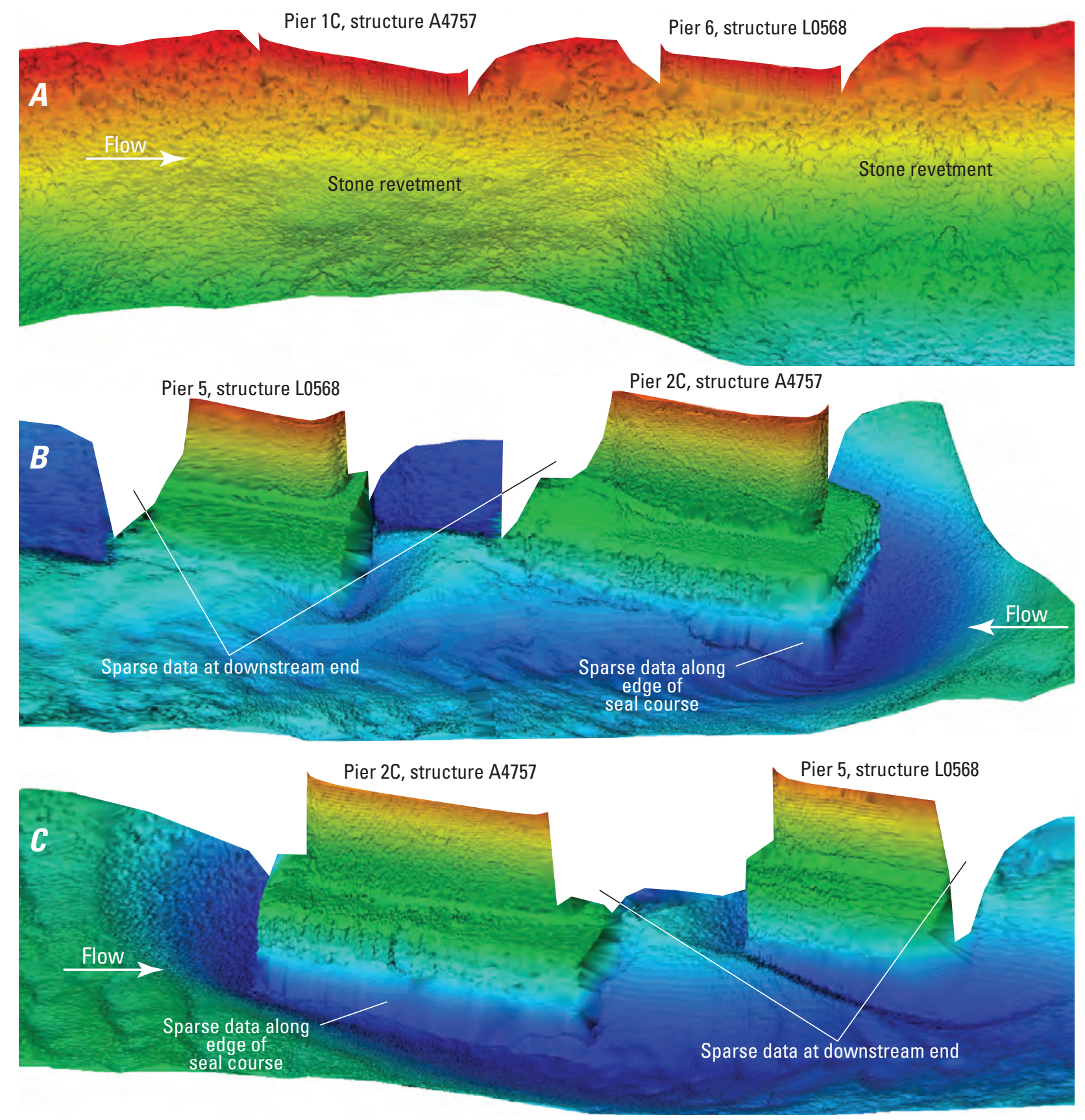

EXPLANATION

Elevation of point, in feet

above the North American

Vertical Datum of 1988

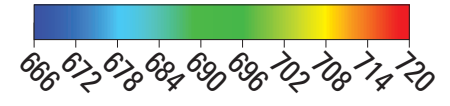

Figure 1.10. Shaded triangulated irregular network visualization of the channel bed and main channel piers of structure A4757 and L0568 on State Highway 291 over the Missouri River in Kansas City, Missouri. $A$, right (south) side of piers $1 \mathrm{C}$ and 6. $B$, left (north) side of piers $2 \mathrm{C}$ and $5 . \mathrm{C}$, right (south) side of piers $2 \mathrm{C}$ and 5 . 
For more information about this publication, contact: Director, USGS Central Midwest Water Science Center 1400 Independence Road

Rolla, M0 65401

573-308-3667

For additional information, visit: https://www.usgs.gov/centers/cmwater

Publishing support provided by the

Rolla and Lafayette Publishing Service Centers 


\section{$\frac{\mathbb{2}}{3}$}

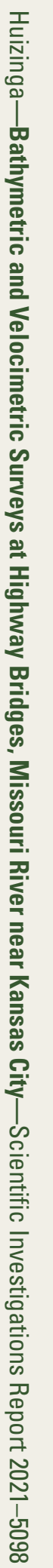

